UNIVERSIDADE DE BRASÍLIA - UnB

INSTITUTO DE GEOCIÊNCIAS - IG

PROGRAMA DE PÓS-GRADUAÇÃO EM GEOCIÊNCIAS APLICADAS

\title{
AVALIAÇÃO DE VIABILIDADE DE APLICAÇÃO DE TÉCNICAS DE RECARGA ARTIFICIAL EM AQUÍFEROS SALINIZADOS, FRATURADOS, PETROLINA - PE
}

DISSERTAÇÃO DE MESTRADO

PÓS-GRADUAÇÃO EM HIDROGEOLOGIA E MEIO AMBIENTE

PRISCILA SOUSA SILVA

Orientador:

Prof. Dr. José Eloi Guimarães Campos 
UNIVERSIDADE DE BRASÍLIA - UnB

INSTITUTO DE GEOCIÊNCIAS - IG

PROGRAMA DE PÓS-GRADUAÇÃO EM GEOCIÊNCIAS APLICADAS

\section{AVALIAÇÃO DE VIABILIDADE DE APLICAÇÃO DE TÉCNICAS DE RECARGA ARTIFICIAL EM AQUÍFEROS SALINIZADOS, FRATURADOS, PETROLINA - PE}

\section{PRISCILA SOUSA SILVA}

\section{Banca Examinadora:}

Prof. Dr. José Eloi Guimarães Campos (Universidade de Brasília - UnB) (orientador)

Prof. Dra. Adriana Chatack Carmelo (Universidade de Brasília - UnB)

Prof. Dr. Luiz Rogério Bastos Leal (Universidade de Federal da Bahia - UFBA)

Data da defesa: $21 / 10 / 2016$. 


\section{AGRADECIMENTOS}

Fazer uma dissertação de mestrado conduzida na UnB morando em Manaus e em uma área de estudo em Pernambuco não foi fácil. E sem a ajuda dessas pessoas eu diria que seria impossível.

Gostaria de agradecer primeiramente a Deus por ter me proporcionado chegar até aqui.

Em segundo lugar minha família e Levi que sempre me apoiaram nos momentos de alegrias e conquistas, mas também nos momentos de cansaço, sono, fome e desespero. Sempre me dando forças para prosseguir em busca dos meus sonhos.

Gostaria de agradecer também meus amigos da UnB e da CPRM pelo apoio e auxílio sempre.

Gostaria de agradecer a Lili e ao Mancini, pois sem eles não existiriam dados de isótopos nessa dissertação.

Ao Hammel e ao Álvaro por terem me auxiliado nas disciplinas, me mantendo informada mesmo tão distante.

À FINEP pelo financiamento do projeto de pesquisa no âmbito da Rede HIDROFRAT.

Ao Rafael (Coxa) e ao Lucas (Bruxão) pelo companheirismo durante toda minha breve jornada.

E principalmente as pessoas que tornaram tudo isso possível, Professor Luciano e meu orientador Professor Eloi.

Siga em frente, olhe para o lado! 


\section{SUMÁRIO}

Índice de Figuras ...............................................................................................

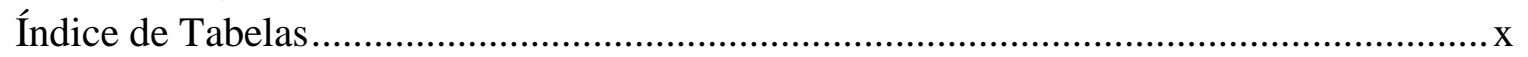

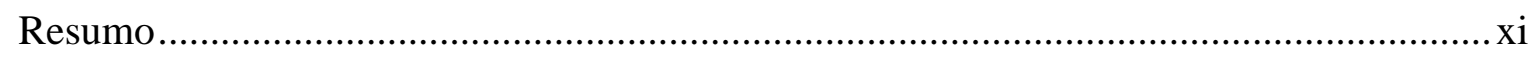

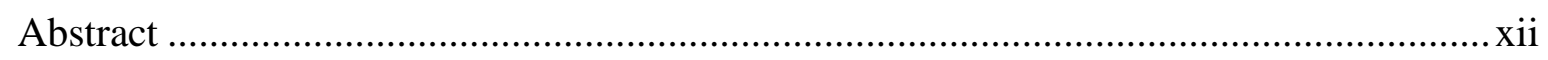

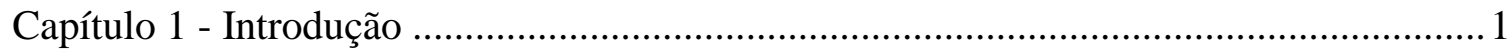

1.1. Apresentação ......................................................................................... 1

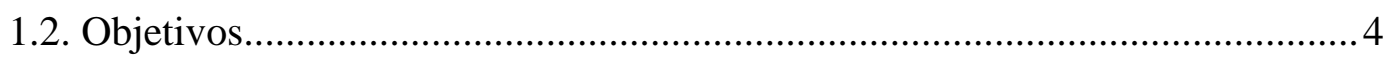

1.3. Justificativas .................................................................................... 4

1.4. Localização da Área de Estudo ..................................................................... 8

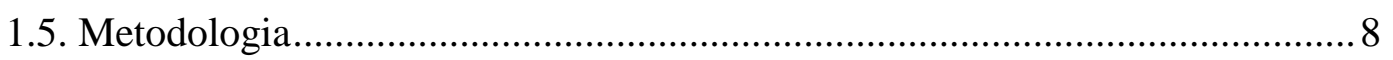

Capítulo 2 - Síntese Sobre o Meio Físico e Aspectos Socioeconômicos .............................. 18

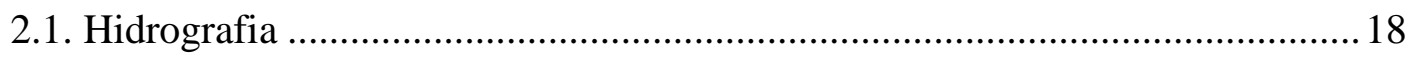

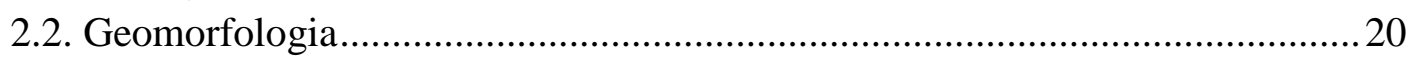

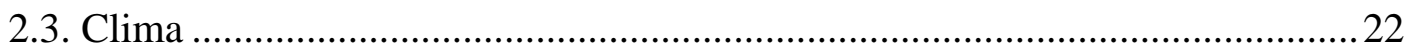

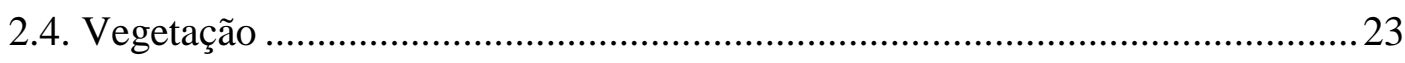

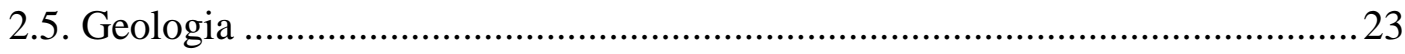

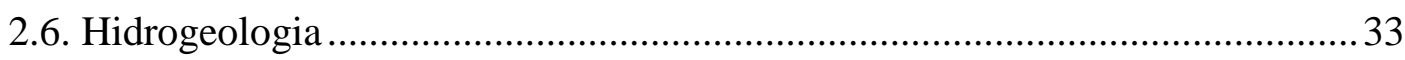

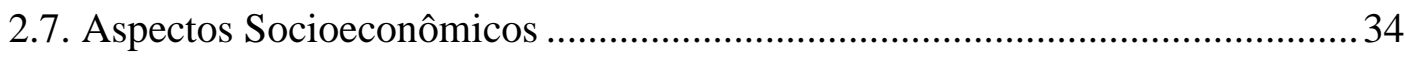

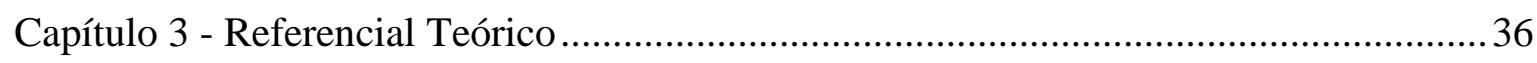

3.1. Recarga Artificial em Meio Fraturado …….................................................... 36

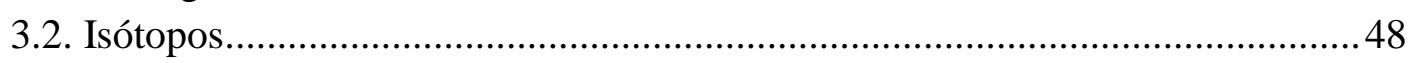

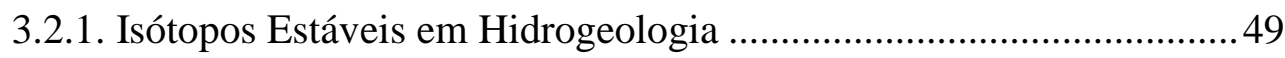

3.2.2. Isótopos Radiogênicos em Hidrogeologia ........................................63

3.3. Salinização das Águas Subterrâneas no Semiárido do Nordeste

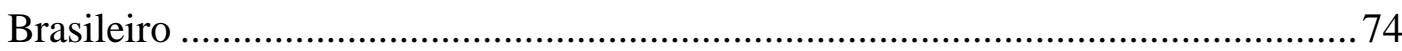

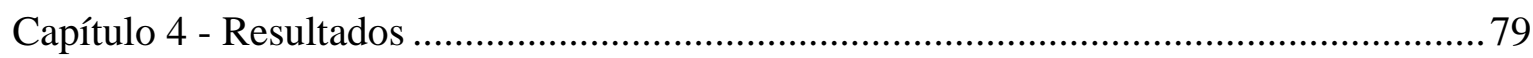

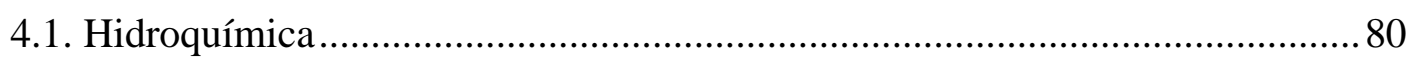

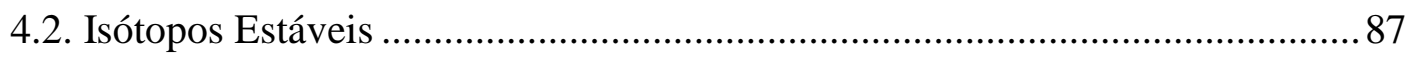

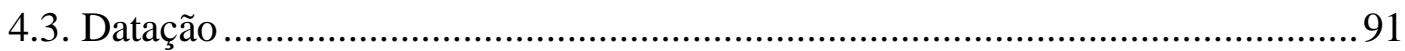

4.4. Sistemas Piloto de Recarga Artificial ......................................................... 92

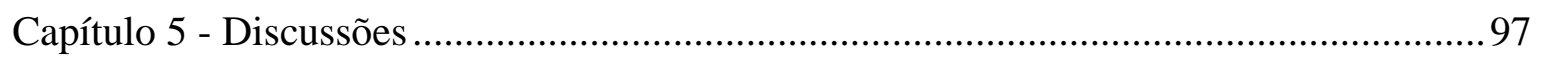

Capítulo 6 - Conclusões e Recomendações..................................................................... 111

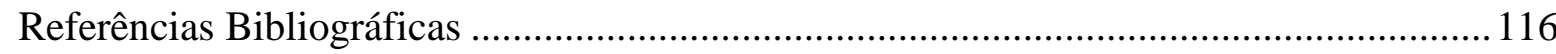

Anexos 


\section{ÍNDICE DE FIGURAS}

Figura 1.1 - Áreas de embasamento cristalino e bacias sedimentares do Brasil com destaque para a região semiárida (CPRM, 2016).

Figura 1.2 - Mapa das condutividades elétricas das águas subterrâneas do Brasil (CPRM, 2016).

Figura 1.3 - Mapa de localização do município de Petrolina-PE....................................... 9

Figura 1.4 - Esquema do Sistema Piloto de Recarga Artificial com poço de monitoramento para solos rasos.

Figura 1.5 - Esquema do Sistema Piloto de Recarga Artificial com poço de monitoramento para solos profundos ou área de acumulação de aluviões arenosos. ..........11

Figura 1.6 - Mapa de localização dos Sistemas Piloto de Recarga Artificial. ..................... 13

Figura 1.7 - Perfil construtivo do poço de monitoramento do Sistema Piloto da Escola Municipal. O poço possui 36 metros de profundidade e apresentou uma vazão aproximada de $4.360,7 \mathrm{~L} / \mathrm{h}$.

Figura 1.8 - Perfil construtivo do poço de monitoramento do Sistema Piloto da Fazenda do Jair. O poço possui 72 metros de profundidade e apresentou uma vazão aproximada de $4.551,2 \mathrm{~L} / \mathrm{h}$.

Figura 1.9 - Fotos dos Sistemas Piloto de Recarga Artificial no município de PetrolinaPE.

Figura 2.1 - Região Hidrográfica do São Francisco com as principais cidades representadas (adaptado de ANA, 2015b).

Figura 2.2 - Principais polos de irrigação da Região Hidrográfica do São Francisco juntamente com estimativas de áreas irrigadas por microbacia (ha). A direita um gráfico representando as demandas hídricas presentes na RH (Adaptado de ANA, 2015b).......... 20

Figura 2.3 - Mapa de geomorfologia de Petrolina (SILVA \& FERREIRA, 2003)............. 21

Figura 2.4 - Evapotranspiração do estado de Pernambuco em mm (adaptado de SILVA

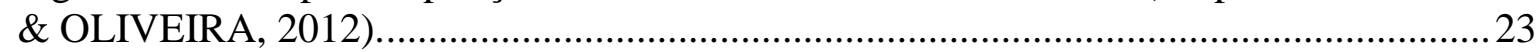

Figura 2.5 - Principais crátons do Brasil (Modificado de ALKMIM, 2004). ...................... 23

Figura 2.6 - Geologia regional do Cráton São Francisco. Ao norte em verde a localização aproximada do município de Petrolina-PE (Modificado de ALKMIM, 2004).

Figura 2.7 - Visão regional da Província Borborema com a compartimentação feita por HASUI (2012). Em preto estão as zonas de cisalhamento Pernambuco e Patos que separam a Província em 3 setores e as linhas azuis representam as zonas de cisalhamento que separam os setores em domínios. Os nomes dos domínios estão em azul e vermelho. E o nome das zonas de cisalhamento em verde. O quadrado laranja representa a localização aproximada do município de Petrolina (Adaptado de HASUI, 2012)

Figura 2.8 - Mapa geológico simplificado da Faixa Riacho do Pontal. O quadrado verde mostra a localização aproximada do município de Petrolina-PE (Adaptado de UHLEIN et al. 2011)

Figura 2.9 - Litotipos da Faixa Riacho do Pontal. A - Metagrauvaca e metapelito da Formação Mandacaru; B - Mica xisto da Formação Barra Bonita, com estrutura S/C, 
devido à deformação tangencial (D1), próximo ao contato com o embasamento, no povoado de Pau Ferro, ao sul de Rajada. C - Suíte Rajada: granitoide foliado, sintectônico, na barragem do açude de Rajada. D - Gnaisse bandado, pertencente ao Embasamento, que aflora como escama tectônica na região de Afrânio (Complexo Morro do Estreito) (UHLEIN et al, 2011).

Figura 2.10 - Mapa geológico do município de Petrolina-PE segundo Beltrão et al. (2005).

Figura 2.11 - Seção geológica simplificada da Faixa Riacho do Pontal e da porção norte do Cráton São Francisco com indicação das zonas interna e externa (UHLEIN et al., 2011)

Figura 2.12 - Roseta de fraturas de pedreira localizada as margens da BR-407 no município de Petrolina-PE.

Figura 2.13 - Fotos dos afloramentos observados no município de Petrolina-PE durante os trabalhos de campo do Projeto RECARFRAT.

Figura 3.1 - Esquema simplificado das respostas esperadas no nível freático com a recarga artificial por bacias de recarga (a) e por poços de injeção (b) (Adaptado de CUSTODIO \& VILARÓ, 1983).

Figura 3.2 - Comportamento simplificado do nível freático em 2 contextos hidrogeológicos simples relativo a recarga artificial em bacia de infiltração circular de raio a. Onde $\mathrm{R}$ é a recarga, $\mathrm{h}_{0}$ é o nível freático inicial, $\mathrm{h}$ é o nível freático máximo após a recarga, $K$ é a condutividade hidráulica e $S_{\mathrm{y}}$ é a vazão específica do aquífero livre aflorante. Esse modelo é restrito para aquíferos homogêneos, isotrópicos, onde $\mathrm{R}<<\mathrm{K}$ e para uma taxa de recarga constante no tempo e no espaço. (a) Representa a elevação do nível freático em aquífero livre horizontal em contato na base com formação impermeável. (b) Representa a recarga artificial em camada pouco permeável aflorante em contato na base com camada permeável (Adaptado de FREEZE \& CHERRY, 1979). 39

Figura 3.3 - Síntese de métodos comumente utilizados para recarga artificial de aquíferos. Os mesmos serão descritos logo em seguida (Adaptado de FEITOSA et al., 2008)

Figura 3.4 - Processo de funcionamento de barreira de infiltração. Um método recarga artificial que consiste no bombeamento próximo a rios.

Figura 3.5 - Exemplo de funcionamento de poço de união.

Figura 3.6 - Exemplos de alterações nos parâmetros físico e químicos sofridos durante recarga artificial. À esquerda em aquífero poroso (Adaptado de CUSTODIO \& VILARÓ, 1983) e a direita em aquífero fraturado (BANTON \& KLISCH, 2007)............44

Figura 3.7 - Variação da capacidade de infiltração em função da permeabilidade horizontal (Adaptado de CUSTODIO \& VILARÓ, 1983).

Figura 3.8 - Variação da capacidade de infiltração durante o processo de recarga artificial (tempo) (Adaptado de CUSTODIO \& VILARÓ, 1983).

Figura 3.9 - Representação esquemática da distribuição da energia potencial causada por forças repulsivas e atrativas entre 2 partículas de cargas opostas no efeito isotópico cinético normal e inverso. Onde uma partícula está localizada no 0 e a outra na linha de energia potencial resultante. As linhas horizontais representam o nível de energia do sistema, sendo que a fina se refere ao isótopo leve e a grossa ao isótopo pesado. $\mathrm{E}_{\mathrm{B}} \mathrm{e}$ $\mathrm{E}_{\mathrm{B}}$ ' representam a energia de ligação do isótopo leve e pesado respectivamente (Adaptado de MOOK, 2001). 
Figura 3.10 - Variações do $\delta^{18} \mathrm{O}_{\text {vsmow }}$ em compostos naturais (Adaptado de MOOK,

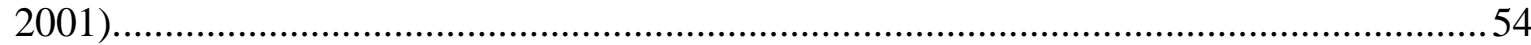

Figura 3.11 - Variações do $\delta \mathrm{D}_{\text {vsmow }}$ em ambientes naturais (Adaptado de MOOK, 2001).55

Figura 3.12 - Esquema simplificado do fracionamento Rayleigh.

Figura 3.13 - Representação esquemática do empobrecimento de ${ }^{18} \mathrm{O}$ do vapor atmosférico e da precipitação conforme o vapor de água se distancia da principal fonte (região tropical) (Adaptado de GAT et al., 2001).

Figura 3.14 - Fator de Enriquecimento Isotópico $(\varepsilon)$ ou Discriminação Isotópica $(\Delta)$ em função da temperatura para um sistema em equilíbrio entre a evaporação e a condensação. $\mathrm{O}$ valor a $20^{\circ} \mathrm{C}$ corresponde à inclinação da curva da água meteórica (GAT et al., 2001).

Figura 3.15 - Exemplos de processos que alteram a curva global da água meteórica (Adaptado de GEYH, 2001).

Figura 3.16 - Alteração na GMWL decorrente do fenômeno excesso de deutério que ocorre em regiões áridas e semiáridas (Adaptado de ARAGUÁS, 2014).

Figura 3.17 - Composição isotópica de ${ }^{87} \mathrm{Sr} /{ }^{86} \mathrm{Sr}$ de amostras de águas engarrafadas plotadas de acordo com a estratigrafia e com a assinatura dos aquíferos fonte das águas (MONTGOMERY et al., 2006).

Figura 3.18 - Variação temporal do $\delta^{18} \mathrm{O}$ durante 3 períodos de injeção de água no sistema de recarga artificial em injeção direta em poços em Damasco, capital da Síria. Os 3 retângulos indicados representam os 3 períodos de injeção, Os pontos vermelhos indicam a assinatura da água de injeção, os pontos brancos a assinatura das águas dos poços que responderam positivamente a recarga (W13 e W14) e os pontos pretos a assinatura dos poços que não responderam a recarga (W15 e WHz) (IAEA, 2013).

Figura 3.19 - Formação do ${ }^{14} \mathrm{C}$ e suas principais ocorrências na natureza (Adaptado de MOOK, 2001).

Figura 3.20 - Representação esquemática da chegada do ${ }^{14} \mathrm{C}$ nos aquíferos. As porcentagens representadas na Figura se referem a razão de atividade do ${ }^{14} \mathrm{C}\left({ }^{14} \mathrm{a}\right)$ que representa a comparação da taxa de decaimento do ${ }^{14} \mathrm{C}$ da amostra com a de um padrão. DIC significa carbono inorgânico dissolvido (MOOK, 2001).

Figura 3.21 - Ilustração esquemática da forma de utilização do isótopo de Carbono 14 para datação de água subterrânea.

Figura 3.22 - Representação gráfica da razão de decaimento do ${ }^{14} \mathrm{C}$ e do $\delta^{13} \mathrm{C}$ para os principais elementos do ciclo hidrológico (adaptado de MOOK, 2001).

Figura 3.23 - Curva de calibração do ${ }^{14} \mathrm{C}$. Na imagem superior, a relação entre a variação do quantitativo de ${ }^{14} \mathrm{C}$ no $\mathrm{CO}_{2}$ atmosférico com a datação acurada de idade de anéis de árvores por vários laboratórios e pelo crescimento anual de corais. $\mathrm{Na}$ curva inferior, a curva de calibração obtida com base na imagem superior (Adaptado de MOOK, 2001).

Figura 3.24 - Origem e distribuição do trítio na natureza. Ao contrário do ${ }^{14} \mathrm{C}$, o trítio decai e desaparece mais rapidamente, exceto quando está fixado em geleiras e na água subterrânea (Adaptado de MOOK, 2001).

Figura 3.25 - Variação do trítio em 2 estações sendo uma representante do hemisfério norte e outra do hemisfério sul (ARAGUÁS, 2014). 
Figura 3.26 - Diagrama esquemático que representa a relação entre o ${ }^{14} \mathrm{C}$ e o ${ }^{3} \mathrm{H}$ em águas subterrâneas de diferentes idades. As águas recentes possuem dezenas de anos, águas jovens possuem centenas de anos, águas velhas possuem milhares de anos, águas muito velhas e águas fósseis possuem dezenas de milhares de anos (MOOK, 2001)........73

Figura 4.1 - Mapa de localização das amostragens realizadas em águas superficiais, subterrâneas e em rocha no município de Petrolina-PE. A escala de tons de vermelho nos sítios de amostragem para caracterização isotópica regional se referem à condutividade elétrica (C.E.) das águas. Quanto mais forte o vermelho, maiores as C.E. .79

Figura 4.2 - Carta Geohidroquímica do Município de Petrolina na escala 1:100.000 elaborada com base na análise hidroquímica de 526 amostras de água subterrânea realizada em 2001/2002.

Figura 4.3 - Diagrama de Piper com as 232 amostras selecionadas pela avaliação do balanço iônico.

Figura 4.4 - Classificação das 232 amostras selecionadas de água subterrânea do município de Petrolina segundo o Diagrama de Piper.

Figura 4.5 - Gráficos de bola representando a porcentagem correspondente a cada íon em uma amostra representativa de cada grupo e o Diagrama de Piper por grupo. ..............82 82

Figura 4.6 - Concentração dos íons das amostras representativas de cada grupo................8 84

Figura 4.7 - Gráficos que relacionam a concentração dos principais íons com as condutividades elétricas para poços de Petrolina-PE.

Figura 4.8 - Gráfico $\delta \mathrm{D}$ versus $\delta^{18} \mathrm{O}$ com a representação das amostras de água subterrânea e superficial (canal de irrigação, Rio São Francisco e amostras de chuva) coletadas no município de Petrolina-PE em relação a GMWL e LMWL. No quadro a direita é possível observar a indicação das amostras coletadas no canal de irrigação e no Rio São Francisco.

Figura 4.9 - Fotos das coletas ao longo do canal de irrigação no município de Petrolina PE.

Figura 4.10 - Resultado das análises isotópicas realizadas nas amostras do canal de irrigação, evidenciando a alta taxa de evaporação presente na região semiárida do nordeste brasileiro.

Figura 4.11 - Água sendo injetada pelo caminhão pipa diretamente na trincheira no Sistema Piloto da Escola Municipal. A camada de xisto presente próximo à superfície se comportou como uma barreira hidráulica não permitindo que a água infiltrasse e chegasse à fratura monitorada pelo poço.

Figura 4.12 - Trincheira de recarga mal preenchida e localizada mais distante do poço de monitoramento no Sistema Piloto da RKF Mudas.

Figura 4.13 - Monitoramento do Sistema Piloto da RKF Mudas......................................... 94

Figura 4.14 - Monitoramento do Sistema Piloto da Fazenda do Jair. .................................96

Figura 4.15 - Secção esquemática simplificada dos poços presentes na fazenda do Senhor Jair

Figura 5.1 - Diagrama Eh X pH do elemento cloro considerando $\left[\mathrm{Cl}^{-}\right]_{\mathrm{TOT}}=18.00 \mathrm{mM}$ a $\mathrm{T}=25^{\circ} \mathrm{C}$. Mostrando que sob as condições das águas subterrâneas, predominantemente redutoras, a forma estável do cloro é em solução $\mathrm{Cl}^{-}$. 
Figura 5.2 - Amostras de água subterrânea de Petrolina plotadas juntamente com GMWL e com a LMWL. As amostras estão localizadas acima das linhas e encontram-se alinhadas formando uma linha denominada "linha da água subterrânea de Petrolina". ....

Figura 5.3 - Amostras de água subterrânea de aquífero fraturado do Canadá de diferentes salinidades plotadas no diagrama $\delta \mathrm{D} \times \delta^{18} \mathrm{O}$. As linhas de aumento de salinidade representam águas salinas resultado da mistura de águas rasas e frescas (localizadas abaixo da GWML) e de salmouras profundas (sinalizadas com o círculo vermelho) (FRAPE et al., 1984).

Figura 5.4 - Variações da curva da água meteórica global prevendo o comportamento de águas subterrâneas decorrente do fracionamento isotópico no processo de interação água-rocha (Adaptado de GEYH, 2001).

Figura 5.5 - Evolução do processo de interação água-rocha nas águas subterrâneas do município de Petrolina com base na análise da razão ${ }^{87} \mathrm{Sr} /{ }^{86} \mathrm{Sr}$.

Figura 5.6 - Relação das idades aproximadas obtidas pelo método carbono 14 com a condutividade elétrica e com o $\delta^{13} \mathrm{C}$.

Figura 5.7 - Seção transversal mostrando as prováveis variações nos conteúdos de Trítio das águas subterrâneas de acordo com a profundidade

Figura 5.8 - Curva da evaporação para amostras coletadas ao longo do canal de irrigação que liga as águas do Rio São Francisco ao interior do município (proximidades do povoado de Uruás).

Figura 5.9 - Variação dos parâmetros físico-químicos e isotópicos durante o monitoramento do Sistema Piloto da RKF Mudas. O quadrante vermelho corresponde à amostra RKF-III-20.

Figura 5.10 - Avaliação do funcionamento do Sistema Piloto da RKF Mudas. O gráfico mostra a assinatura isotópica inicial do aquífero, da água utilizada na recarga e da possível mistura.

Figura 5.11 - Indicação das alterações nos parâmetros físico-químicos e isotópicos no momento da chegada da água da recarga artificial apontada pela Figura 5.12.

Figura 5.12 - Avaliação do funcionamento do Sistema Piloto da Fazenda do Jair. O gráfico mostra a assinatura isotópica inicial do aquífero, das águas utilizadas na recarga e da mistura. 


\section{ÍNDICE DE TABELAS}

Tabela 1.1 - Localização dos Sistemas Piloto de Recarga Artificial.

Tabela 2.1 - Caracterização das Unidades Hidrográficas da RH do São Francisco. Em destaque a unidade na qual o município de Petrolina está localizado (Adaptado de IBGE, 2010 Input ANA, 2015b).

Tabela 2.2 - Tabela de descrição das unidades geoambientais presentes no município de Petrolina-PE (SILVA \& FERREIRA, 2003)..

Tabela 2.3 - Precipitação acumulada por trimestre do município de Petrolina-PE (Adaptado de INMET, 2016).

Tabela 3.1 - Isótopos estáveis dos principais elementos utilizados como traçadores ambientais e suas respectivas abundâncias (Adaptado de MARTINELLI et al., 2009).....50

Tabela 3.2 - Principais padrões dos isótopos estáveis mais utilizados em estudos ambientais.

Tabela 4.1 - Características dos grupos separados para análise hidroquímica. .82

Tabela 4.2 - Resultado das análises de ${ }^{87} \mathrm{Sr} /{ }^{86} \mathrm{Sr}$ em amostras de água subterrânea e rocha coletadas no município de Petrolina-PE.

Tabela 4.3 - Dados de datação por trítio e carbono 14 para as amostras de água subterrânea do município de Petrolina.

Tabela 4.4 - Características das águas de recarga utilizadas no teste do Sistema Piloto da RKF Mudas.

Tabela 4.5 - Características das águas de recarga utilizadas no teste do Sistema Piloto da Fazenda do Jair. .95

Tabela 5.1 - Estimativa do tempo necessário para que a água subterrânea de Petrolina seja considerada doce com o Sistema Piloto funcionando de maneira natural com a água da chuva. 


\section{RESUMO}

O município de Petrolina possui uma série de especificidades que o torna particular do ponto de vista hidrogeológico. A questão da escassez de recursos hídricos se dá, tanto do ponto de vista quantitativo (em função do clima, dos solos e da natureza dos aquíferos,); quanto qualitativo (em função da elevada salinidade das águas subterrâneas). O clima da região é classificado como semiárido, sendo que as temperaturas são elevadas e as chuvas são escassas e irregulares temporal e espacialmente. O substrato geológico da região é representado por granitos, gnaisses e metassedimentos, pertencentes ao Bloco Gavião do Cráton São Francisco e à Faixa Móvel Riacho do Pontal, de idades do Paleoarqueano ao Neoproterozoico; além de sedimentos recentes de depósitos aluvionares, lateríticos e paleodunas. As coberturas de solos e regolitos são pouco espessas e os sedimentos aluvionares podem acumular espessuras de 5 a 10 metros. Dessa forma, as zonas aquíferas da região ocorrem em fraturas pouco conectadas o que resulta em uma circulação limitada da água subterrânea. A recarga dos aquíferos é reduzida devido ao clima e a alta taxa de evaporação. A salinidade das águas subterrâneas é elevada e se dá pela atuação conjunta de fatores como: clima, solo, relevo plano, recarga restrita (baixa disponibilidade de água), baixa conectividade das fraturas, circulação restrita de água no aquífero e elevado tempo de contato água-rocha. Com o intuito de melhorar a qualidade das águas subterrâneas do município, diminuindo sua salinidade, foi proposto um sistema piloto de recarga artificial. Com a diminuição da salinidade é possível aumentar a potencialidade de uso dos recursos hídricos subterrâneos. De forma sintética, o sistema é composto por um conjunto de calhas e tubulações de coleta de água da chuva em telhados, uma trincheira de recarga preenchida por cascalho e um poço tubular para bombeamento e monitoramento da qualidade da água subterrânea. Foram construídos três Sistemas Piloto de Recarga Artificial no município de Petrolina-PE para verificação de sua viabilidade hidráulica e aplicabilidade. Os testes foram realizados pela indução da recarga artificial através da injeção de água nas trincheiras de recarga por caminhões pipa. O monitoramento foi realizado com análises de isótopos estáveis, $\delta \mathrm{D}(\%)$ e $\delta^{18} \mathrm{O}(\%)$, e de condutividade elétrica, $\mathrm{pH}$ e Eh in situ. Os testes mostraram que o sistema apresenta viabilidade hidráulica, e que seu sucesso depende da adequada localização e construção do sistema piloto. Já a aplicabilidade e a efetividade do sistema piloto apresentam maior complexidade devido à necessidade de grande quantidade de água na recarga artificial para que a água subterrânea salina possa ser utilizada de maneira mais ampla. Como as chuvas na região são restritas, estima-se que seja necessário um longo período de tempo para que os sistemas de recarga apresentem resultados satisfatórios. Complementarmente ao teste dos sistemas pilotos foram realizadas análises hidroquímicas de amostras de água subterrânea, análises da razão ${ }^{87} \mathrm{Sr} /{ }^{86} \mathrm{Sr}$ de água e rocha, análise isotópica ( $\delta \mathrm{D}(\%)$ e $\delta^{18} \mathrm{O}(\%)$ ) de amostras ao longo do canal de irrigação, caracterização isotópica regional dos aquíferos e datação das águas subterrâneas. A avaliação conjunta dos dados permitiu que contribuições ao conhecimento com respeito à recarga natural, interação água-rocha e salinização das águas subterrâneas do semiárido nordestino fossem alcançadas.

Palavras-chave: Isótopos Estáveis $\left(\delta^{18} \mathrm{O}\right.$ e $\left.\delta \mathrm{D}\right)$, Recarga Artificial, Semiárido Nordestino, Salinização, Aquífero Fraturado. 


\begin{abstract}
The Petrolina County, State of Pernambuco, Brazil has several peculiarities that make it particular in the hydrogeological point of view. The water resources scarcity issue is related to quantitative (depending on the weather, the soil and the nature of aquifers) and qualitative (due to the high salinity of groundwater). The climate of the region is classified as semiarid, with scarce rains irregular on time and spatially and with high temperatures. The geology is represented by granites, gneisses and metassediments, of the São Francisco Craton and of the Riacho do Pontal Mobile Belt, with ages since Paleoarchean to Neoproterozoic, in addition to recent sediments of alluvial, lateritic and paleo dunes deposits. The coverage soil and regolith show small thickness and alluvial sediments can accumulate up to 10 meters. In this way, the regional aquifers occur in low connected fractures resulting in a limited circulation of groundwater. The aquifers recharge is reduced due to the climate and the high evaporation rate. The salinity of groundwater is high due to joint action of factors such as: climate, soil, plan relief, restrict recharge (low water availability), low connectivity of fractures, and restricted circulation of water in the aquifer and high water-rock time contact. In order to improve the quality of the groundwater of the region, decreasing its salinity, a pilot artificial recharge system was proposed. With the salinity decreasing it is possible to increase the groundwater usage potential. In a synthetic form, the pilot systems consist of a set of gutters and pipes of rainwater collecting on roofs, a recharge trench filled with gravel and a tubular well for pumping and monitoring groundwater quality. Three artificial recharge systems were built in the Petrolina area to verification of hydraulic feasibility and applicability. The tests were conducted by the induction of artificial recharge by injecting water in the recharge trenches by tanker trucks. The monitoring was conducted with analyses of stable isotopes, $\delta \mathrm{D}(\%)$ and $\delta^{18} \mathrm{O}(\%)$, and in situ measures of electrical conductivity, $\mathrm{pH}$ and reduction-oxidation potential. The tests showed that the systems show hydraulic feasibility, and that its success depends on the adequate location and construction of the pilot systems. By the other hand, the applicability and effectiveness of the pilot system exhibit greater complexity due to the necessity of large amounts of water in artificial recharge to result on groundwater more widely usage. As the rains in the region are restricted, it is estimated the need of a long period of time to recharge systems get results. In addition to the pilot systems test, hydrochemical analysis of groundwater samples, ${ }^{87} \mathrm{Sr} /{ }^{86} \mathrm{Sr}$ ratio analyses of rock and water, isotopic analysis $\left(\delta \mathrm{D}(\%)\right.$ and $\left.\delta^{18} \mathrm{O}(\%)\right)$ of samples along the irrigation channel, isotopic characterization of aquifers and groundwater dating were carried out. The joint assessment of the data allowed reaching contributions to the knowledge about the natural recharge, water-rock interaction and salinization of groundwater from the semiarid Northeast region of Brazil.
\end{abstract}

Keywords: Stable Isotopes $\left(\delta^{18} \mathrm{O}\right.$ and $\left.\delta \mathrm{D}\right)$, Artificial Recharge (MAR - Managed Aquifer Recharge), Brazilian Semiarid Northeast Region, Salinization, Fractured Aquifer. 


\section{CAPÍTULO 1}

\section{INTRODUÇÃO}

\subsection{Apresentação}

No Brasil grande parte da demanda de água é suprida com a utilização de recursos hídricos superficiais. Tal fato é decorrente, em grande parte, da facilidade de retirada desses recursos comparativamente com a explotação de mananciais subterrâneos. Porém, nas últimas décadas, tem se observado uma participação cada vez maior da utilização da água subterrânea em escala nacional. O crescimento constante da demanda por água, a poluição de mananciais superficiais, aliado as crises hídricas ocasionadas por falta de planejamento por parte da esfera pública e por fenômenos climáticos extremos, cada vez mais comuns, tem contribuído para essa questão.

O interesse por pesquisas voltadas para os recursos hídricos subterrâneos vem crescendo tanto no cenário nacional como internacional. Segundo dados da Agência Nacional de Águas ANA, no ano de 2010, 47\% dos municípios brasileiros eram abastecidos exclusivamente por mananciais superficiais, 39\% exclusivamente por mananciais subterrâneos e 14\% possuíam abastecimento misto (ANA, 2010).

Para a utilização dos recursos hídricos subterrâneos, se faz uso de aquíferos profundos livres ou confinados - com explotação a partir de poços tubulares profundos - e de aquíferos freáticos (rasos) e livres - a partir de poços escavados (cisterna, cacimba ou poço amazonas).

A escolha dentre as alternativas de uso de aquíferos profundos ou rasos, em geral, é feita a partir de variáveis econômicas, de forma que populações de baixa renda ficam restritas à opção de menor custo representada pela captação de águas freáticas. A forma de captação da água subterrânea também sofre influência de aspectos como: características naturais dos aquíferos, qualidade da água subterrânea, eficiência da rede de distribuição pública e disponibilidade hídrica superficial. Tais fatores controlam, por exemplo, a profundidade média dos poços tubulares que pode variar de 60 até centenas de metros.

A região semiárida brasileira é amplamente conhecida pela escassez de recursos hídricos. A disponibilidade hídrica é baixa e insuficiente para o abastecimento da população que sofre devido a esse aspecto. Como no restante do país, a demanda de água da região semiárida é atendida principalmente por recursos hídricos superficiais, sendo que a principal fonte de abastecimento superficial utilizada é a Bacia Hidrográfica do São Francisco.

A utilização dos mananciais subterrâneos merece atenção em um contexto emergencial, como no caso de secas, para um efetivo gerenciamento dos recursos hídricos. Já que o efeito dos eventos extremos nas reservas subterrâneas é mais brando comparativamente aos efeitos nas águas superficiais. Um fato preocupante nesse sentido é a falta de informação tanto do número quanto da situação das captações existentes no semiárido. Nota-se nas áreas das rochas cristalinas uma grande quantidade de poços desativados ou abandonados por desconhecimento da população sobre a hidrogeologia da área (BELTRÃO et al., 2005).

A dificuldade de encontrar fontes hídricas com qualidade e quantidade adequadas torna a questão do abastecimento de água crítico nessa região há anos. Diante do exposto, a utilização conjunta de recursos hídricos superficiais e subterrâneos na região semiárida brasileira vem sendo considerada pelo poder público, porém ainda está muito aquém do ideal. O uso da água 
subterrânea em conjunto com a água superficial oferece grandes expectativas para o futuro da região.

Quanto ao uso da água subterrânea, as áreas de bacias sedimentares são mais propícias para esse fim já que as águas, em geral, são de melhor qualidade e sua explotação é facilitada (ANA, 2015a). Um agravante para o uso dos mananciais subterrâneos no semiárido nordestino é que a maior parte dos municípios em estado crítico de abastecimento está localizada em áreas de embasamento cristalino, onde os aquíferos são fraturados (Figura 1.1).

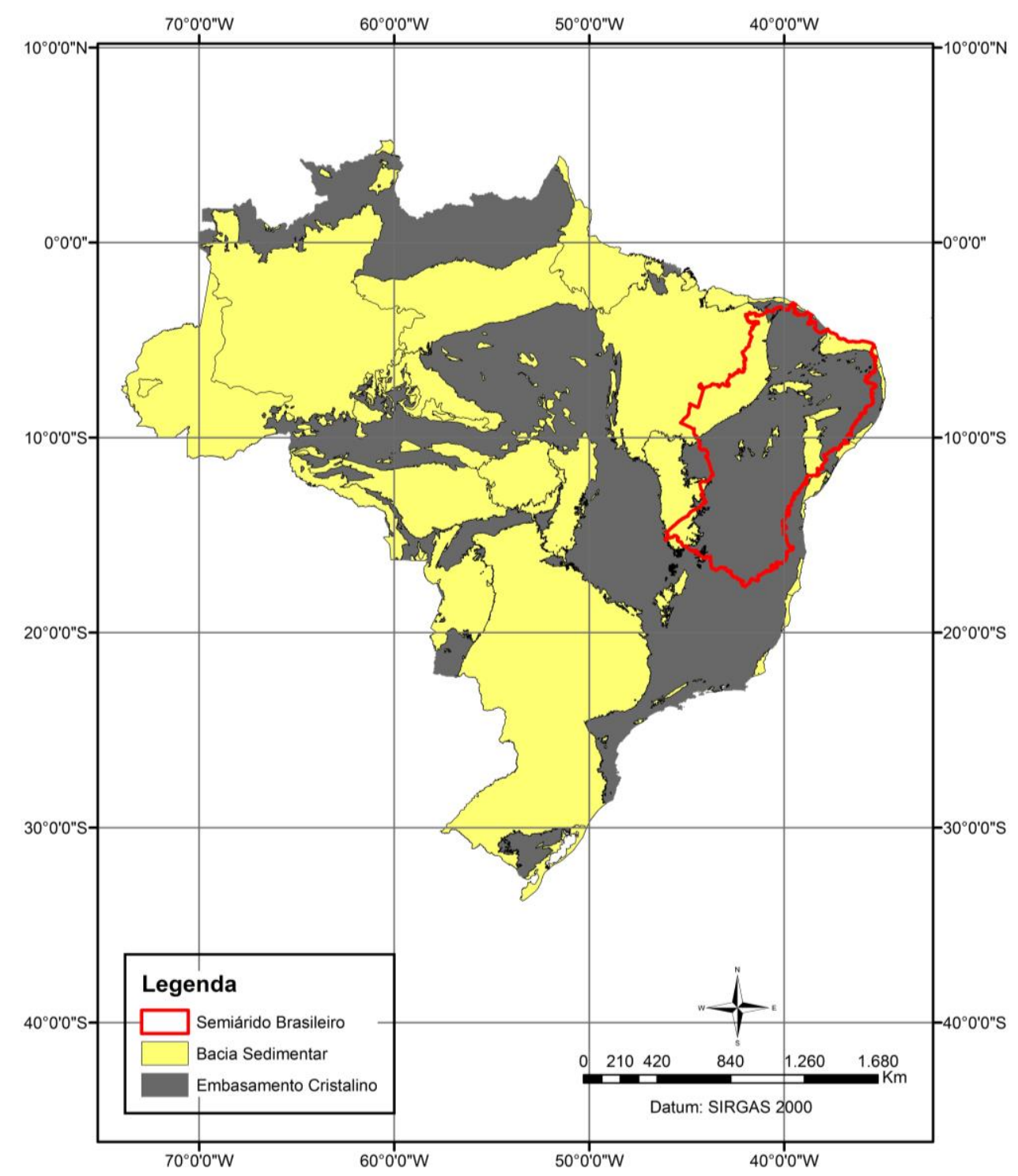

Figura 1.1 - Áreas de embasamento cristalino e bacias sedimentares do Brasil com destaque para a região semiárida (CPRM, 2016).

Os aquíferos fraturados representam $51,5 \%$ do território brasileiro. Nestas áreas estão localizadas, total ou parcialmente, milhares de cidades importantes que fazem uso de suas águas para o abastecimento público e privado. Embora esses aquíferos desempenhem um importante papel na segurança hídrica são eles os menos conhecidos ao nível necessário para a correta gestão do seu uso e proteção. A dificuldade de se entender o fluxo da água nesses reservatórios reside, principalmente, na complexidade da geometria do sistema. A conectividade das estruturas geológicas rúpteis e dúcteis imprime uma grande variação de condutividade hidráulica que controla o fluxo subterrâneo. Isto é reflexo da interação da tectônica pretérita e atual com a 
reologia das rochas que acabam criando um sistema heterogêneo e anisotrópico. Por esses motivos a explotação da água subterrânea possui custos elevados e maiores dificuldades na locação dos poços, comparativamente com a explotação em bacias sedimentares. Além disso, as águas subterrâneas de aquíferos fraturados em algumas localidades do nordeste brasileiro possuem elevados teores de sais dissolvidos o que as torna impróprias para consumo humano.

A origem da mineralização das águas subterrâneas ainda não está clara. Gascoyne \& Kamineni (1994) assumem que a origem deve estar associada à matriz da rocha reservatório, a partir do contato prolongado do sistema água/rocha ao longo das fissuras e fraturas. Hofmann \& Tröger (1998) discutiram a possibilidade de origem atmosférica dos minerais transportados em conjunto com os solos finos e as soluções de escoamento superficial. Sob condições climáticas de elevada evapotranspiração, a água residual na superfície do terreno fica enriquecida em sais. Os cátions são derivados dos próprios minerais formadores das rochas. A origem do cloreto é complexa uma vez que este elemento não é comum em granitos e gnaisses, rochas típicas de embasamentos cristalinos (em geral o cloreto pode ocorrer apenas como um substituinte da hidroxila $\left(\mathrm{OH}^{-}\right)$e do flúor na estrutura de determinadas micas).

Existem diversas maneiras de tentar buscar solução para o problema das águas com alta salinidade localizadas no meio cristalino do nordeste. $\mathrm{O}$ mais utilizado e estudado ultimamente tem sido o uso de dessalinizadores. Outro recurso que pode ser utilizado é a recarga artificial dos aquíferos a partir da diluição da água salina com água doce.

Nesse sentido foi proposto, pela equipe do projeto RECARFRAT, um sistema piloto de recarga artificial cujo objetivo é a diminuição da salinidade das águas dos aquíferos fraturados da região semiárida brasileira. Melhorando dessa forma a qualidade das águas e aumentando suas possibilidades de uso.

O município de Petrolina, localizado no estado de Pernambuco, foi escolhido para o teste do sistema piloto de recarga artificial. Este município apresenta importância regional sendo grande produtor de frutas para exportação. Por esse motivo, a demanda de água é grande. Outro ponto importante é a facilidade de acesso ao município que possui aeroporto que auxilia na logística de grande parte do sertão nordestino. Próximo à sede do município há uma pedreira abandonada onde é possível uma observação das características das fraturas da região. Além disso, o município possui um acervo de 526 poços catalogados com análise química completa que serviu como importante banco de dado hidrogeológico para a pesquisa.

Esta Dissertação de Mestrado está vinculada a Rede HIDROFRAT (Hidrogeologia de Aquíferos Fraturados: entendimento da circulação da água e de contaminantes para uma melhor gestão dos recursos hídricos). Essa rede foi criada a partir de um projeto de pesquisa financiado pela FINEP (Fundo de Financiamento de Estudos de Projetos e Programas) e representa a ação conjunta de instituições de ensino superior que visa à realização de estudos que sirvam de base para tomada de decisões quanto à gestão dos recursos hídricos subterrâneos em diferentes regiões do país. Participam da rede a Universidade de Brasília (UnB), Universidade de São Paulo (USP), Universidade Federal do Rio Grande do Sul (UFRGS) e Universidade Federal do Espírito Santo (UFES).

O projeto de responsabilidade da Universidade de Brasília (UnB), na rede HIDROFRAT, é denominado RECARFRAT (Gestão de Recursos Hídricos Subterrâneos em Regiões Semiáridas: Recarga Artificial dos Aquíferos). 


\subsection{Objetivos}

O objetivo central do RECARFRAT é entender os processos de recarga e conhecer com maior detalhe os processos de circulação da água subterrânea dos aquíferos fraturados em meios cristalinos no semiárido nordestino e propor um sistema inovador de recarga artificial, para melhoria da qualidade das águas captadas de poços tubulares, a partir da diminuição de sua salinidade. A presente dissertação visa aplicar e avaliar a viabilidade hidráulica e a aplicabilidade do sistema piloto de recarga artificial desenvolvido pelo projeto RECARFRAT para aquíferos fraturados com o objetivo de melhorar a qualidade das águas subterrâneas diminuindo o elevado teor de sais dissolvidos. Para tanto, foram integradas técnicas de sensoriamento remoto, geologia estrutural (neotectônica), geofísica, hidroquímica e isótopos estáveis e radiogênicos.

Dentro do objetivo principal que norteia a presente dissertação existem objetivos secundários, porém não menos importantes. Dentre eles destacam-se:

- Ampliar o conhecimento com relação à recarga natural dos aquíferos fraturados do nordeste do Brasil;

- Entender como se dá a circulação da água nos meios fraturados do município de Petrolina-PE;

- Colaborar para ampliação do conhecimento sobre aquíferos fraturados em regiões semiáridas;

- Gerar dados que auxiliem os órgãos públicos na tomada de decisão quanto à gestão dos recursos hídricos subterrâneos na região semiárida brasileira;

- Ampliar o conhecimento sobre as causas das altas salinidades das águas subterrâneas dos aquíferos fraturados da região semiárida brasileira;

- Conhecer a composição química das águas e sua modificação antes e depois da implantação da recarga artificial;

- Conhecer a evolução dos isótopos ambientais antes e depois da implantação da recarga artificial;

- Ampliar o conhecimento sobre o processo de interação água-rocha nos aquíferos fraturados do semiárido brasileiro;

- Avaliar a idade das águas subterrâneas de diferentes salinidades do município de Petrolina-PE;

- Conhecer a trajetória de evaporação dos canais de irrigação do município de PetrolinaPE e;

- Avaliar a efetividade da proposta para recarga artificial, a partir da instalação de sistemas pilotos e realização de testes.

\subsection{Justificativas}

A região semiárida brasileira abrange os estados de Alagoas, Bahia, Ceará, Minas Gerais, Paraíba, Pernambuco, Piauí, Rio Grande do Norte e Sergipe ocupa uma área de aproximadamente $977.000 \mathrm{Km}^{2}$ e possui uma população estimada em 20 milhões de habitantes, sendo que aproximadamente $56 \%$ encontram-se na área urbana e $44 \%$ na área rural (ANA, 2010).

Essa região é conhecida pelas chuvas restritas, altas temperaturas durante todo o ano com baixas amplitudes térmicas $\left(2\right.$ a $\left.3^{\circ} \mathrm{C}\right)$, forte insolação, altas taxas de evapotranspiração e, consequentemente, pelo déficit hídrico. A pluviosidade é geralmente superada pelas altas taxas de evapotranspiração resultando em um balanço hídrico com valores negativos. Assim, a reserva 
de água presente nos mananciais é insuficiente e não oferece garantia de água para os seus diversos usos, em particular, para o abastecimento humano. A escassez de recursos hídricos é preocupante nessa região do país e afeta de maneira direta a vida da população e o seu desenvolvimento econômico e social (ANA, 2015b).

Segundo dados do Atlas de Abastecimento Urbano da Agência Nacional de Águas, dos 1.794 municípios estudados do nordeste brasileiro somente 466 possuem abastecimento de água satisfatório segundo dados de 2015, e 1.312 requerem investimentos nesse sentido (ANA, 2015c).

Como já explanado anteriormente, a demanda de água da região semiárida do nordeste é atendida principalmente por recursos hídricos superficiais. Porém, as pesquisas voltadas para o uso conjunto de recursos hídricos subterrâneos e superficiais vêm crescendo no cenário nacional. Tal uso vem sendo cogitado pelo poder público, porém ainda está muito aquém do ideal.

O Serviço Geológico do Brasil (CPRM) recebeu a tarefa do Governo Federal de realizar estudos e pesquisas visando à busca de soluções para o abastecimento de água da população que sofre com a seca extrema. Foram realizados estudos, desde 2012, em 69 municípios sendo que a medida sugerida foi expandir a utilização dos recursos hídricos subterrâneos. Como fruto deste trabalho foi criado uma rede de poços estratégicos no semiárido. A maior parte dos municípios afetados pela falta de água se localiza na região do cristalino, porém a equipe de pesquisadores tomou a decisão de alocar os poços nas bordas das bacias e fazer o transporte da água por caminhões pipa até tais municípios. Em outubro de 2014, 24 poços haviam sido perfurados (CPRM, 2014a).

O Programa Água Doce, criado em 2003 e coordenado pelo Ministério do Meio Ambiente, trabalha visando o estabelecimento de políticas públicas permanentes para acesso a água de qualidade para consumo humano por meio do aproveitamento sustentável de água subterrânea. O Programa prioriza regiões com dificuldades de acesso aos recursos hídricos, baixos índices de chuvas, baixo Índice de Desenvolvimento Humano (IDH) e alto percentual de mortalidade infantil. Hoje abrange os estados: Piauí, Ceará, Rio Grande do Norte, Paraíba, Pernambuco, Alagoas, Sergipe, Bahia e Minas Gerais. Os municípios contemplados recebem dessalinizadores que tornam a água de poços tubulares adequada para consumo humano (CPRM, 2015)

A Secretaria Executiva de Recursos Hídricos da Secretaria de Desenvolvimento Econômico (SDEC) de Pernambuco inaugurou um sistema pioneiro de dessalinizador solar para ser aplicado nas águas salinas de poços tubulares no sertão do estado (GREENME, 2015).

Como demonstrado pelos projetos acima citados, o uso da água subterrânea em conjunto com a água superficial oferece grandes expectativas para o futuro da região semiárida brasileira. Andrade \& Leal (2010) dizem que o poço tubular é comprovadamente uma das soluções mais apropriadas para o abastecimento humano e animal no meio rural do semiárido nordestino. Segundo tais autores o uso de dessalinizadores tem mostrado boa eficiência para a problemática da elevada salinidade das águas (ANDRADE \& LEAL, 2010).

Entretanto, um agravante para o uso dos mananciais subterrâneos nessa região do país é que a maior parte dos municípios em estado crítico de abastecimento de água está localizada em áreas de embasamento cristalino (aquíferos fraturados). Devido ao condicionamento geológicoestrutural peculiar, as zonas aquíferas em fissuras de rochas cristalinas são limitadas lateralmente, se localizando, normalmente, em faixas estreitas que acompanham zonas de falhas e fraturas regionais. Por isso formam reservatórios anisotrópicos, heterogêneos e de geometria 
complicada. A heterogeneidade e anisotropia desse tipo de aquífero dificultam a explotação da água subterrânea, sendo que a locação e perfuração de poços possui maior complexidade comparativamente com a explotação em aquíferos intergranulares existentes nas áreas de bacias sedimentares.

Além disso, as águas subterrâneas de aquíferos fraturados em algumas localidades do nordeste brasileiro possuem elevados teores de sais dissolvidos o que as torna impróprias para consumo humano. A Figura 1.2 mostra uma interpolação realizada com dados de condutividade elétrica de águas subterrâneas de todo território brasileiro. Os dados utilizados para confecção da interpolação foram retirados da base de dados do SIAGAS pertencente ao Serviço Geológico do Brasil (CPRM). É nítido na imagem que altos valores desse parâmetro são encontrados na região semiárida brasileira (CPRM, 2016).

Portanto, em regiões semiáridas a questão da escassez de recurso hídrico se dá, tanto do ponto de vista quantitativo, em função da ocorrência restrita e concentrada das chuvas, quanto qualitativa, em função da ampla salinidade das águas.

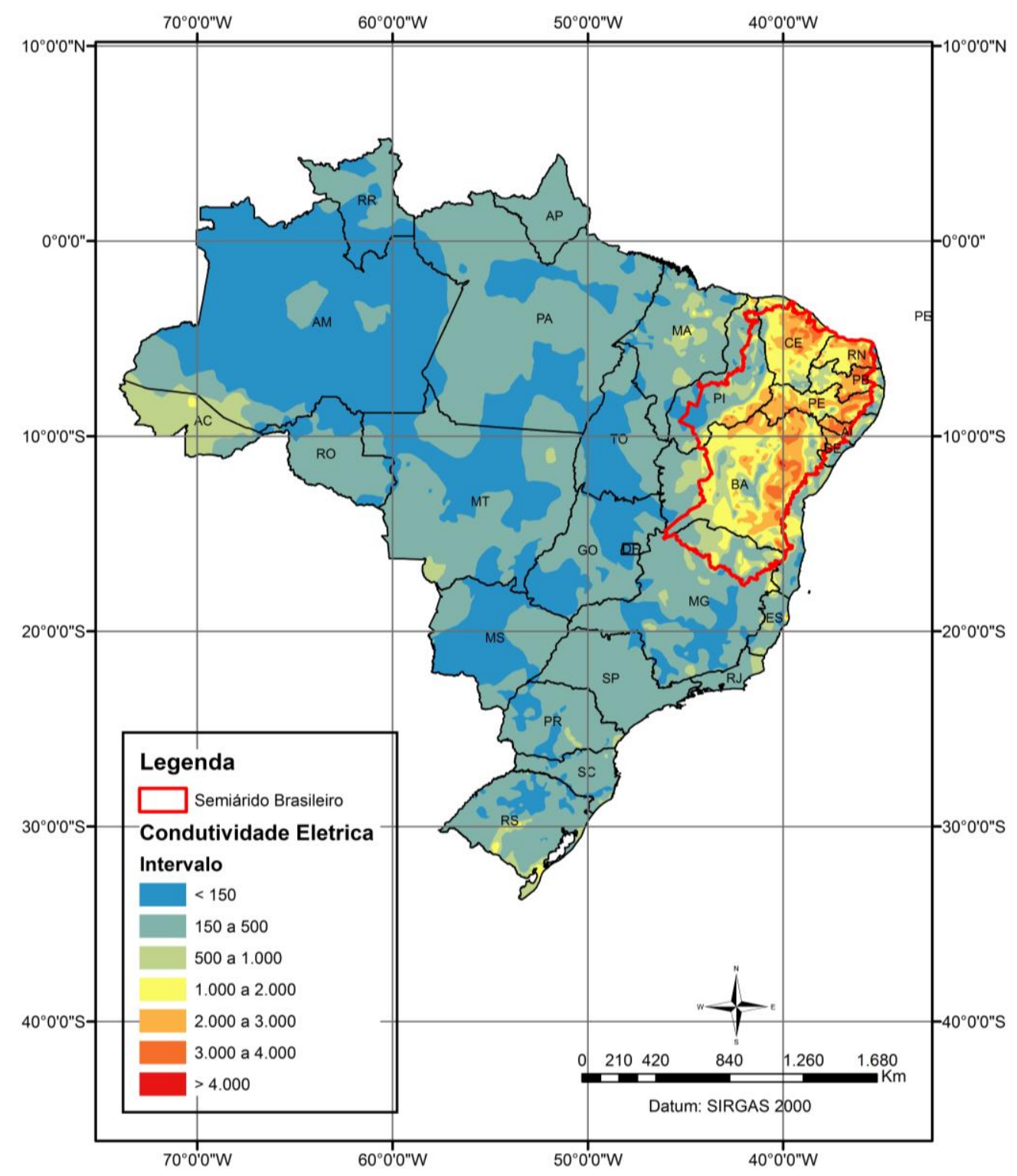

Figura 1.2 - Mapa das condutividades elétricas das águas subterrâneas do Brasil (CPRM, 2016). 
Pensando em um possível aproveitamento dessas águas salinas dos aquíferos fraturados do nordeste brasileiro, o projeto RECARFRAT desenvolveu um sistema piloto de recarga artificial cujo objetivo é melhorar a qualidade de tais águas pela diminuição de sua salinidade, aumentando assim as suas possibilidades de uso. O sistema foi elaborado, implantado e avaliado de maneira a obter respostas quanto à sua efetividade e aplicabilidade.

No caso específico do presente estudo, não se pretende aplicar a recarga artificial para ampliar a oferta de águas subterrânea, uma vez que não há pressão de sobrexplotação dos aquíferos considerados. A indução da infiltração pretende melhorar a qualidade das águas dos aquíferos fraturados diminuindo sua salinidade.

Apesar de ser encontrada ampla literatura internacional no tema sobre recarga artificial de aquíferos fraturados (BOUWER, 2002; ASANO, 1985; GROVEA \& WOOD, 1979; OKUBO \& MATSUMOTO, 1979), no Brasil, este tipo de pesquisa é muito limitada e incipiente, sendo que o desenvolvimento deste tipo de projeto é fundamental para nivelar o entendimento sobre a recarga ao nível daquele que é conhecido para sistemas intergranulares.

O município escolhido para o teste do sistema piloto foi Petrolina no estado de Pernambuco. A escolha do município para o desenvolvimento da pesquisa é justificada por se tratar de uma área com conhecimento prévio de diferentes aspectos da hidrogeologia regional e do fato de se poder contar com importante acervo de poços com dados hidroquímicos completos. Além disso, o município conta com um aeroporto o que facilita a logística e diminui os custos associados ao projeto.

Segundo dados do Atlas de Abastecimento Urbano da ANA, 100\% do município é abastecido atualmente por água superficial do Rio São Francisco, que é distribuída através de adutoras. Essa mesma fonte classifica a disponibilidade de água insuficiente e sugere ampliação do sistema (ANA, 2015c). Apesar disso, o município, juntamente com Juazeiro, forma o polo de irrigação Petrolina-Juazeiro que é grande produtor de frutas e verduras para exportação e possui importância econômica regional.

No município de Petrolina a água subterrânea dos aquíferos fraturados é utilizada em pequena quantidade comparativamente com a utilização da água superficial devido à sua alta salinidade e as características das fraturas na região que possuem baixa interconexão o que ocasiona dificuldades na locação dos poços, sendo que grande parte dos poços perfurados são secos. Os usos da água subterrânea no município são para dessedentação de animais (bodes e cabras em sua maioria) e para irrigação de pequenas áreas.

A diminuição da salinidade das águas subterrâneas aumentaria suas possibilidades de uso e esta poderia complementar o abastecimento do município. As opções de usos após a recarga artificial só serão conhecidas quando for determinada a qualidade detalhada da água gerada após o processo.

Um aspecto importante que justifica a presente proposta é o impacto social e econômico que os eventuais resultados positivos podem alcançar. A escassez de água de boa qualidade natural é um dos fatores que mais limitam o desenvolvimento e a qualidade de vida da população residente em regiões de clima semiárido.

O município de Petrolina foi escolhido para serem feitos os testes do sistema piloto de recarga artificial, sendo que a depender dos resultados obtidos, esse modelo de sistema poderá ser implantado em outras regiões do nordeste brasileiro. Além disso, os conhecimentos adquiridos no presente estudo poderão auxiliar na locação de novos poços na região. 


\subsection{Localização da Área de Estudo}

O município de Petrolina se localiza no limite sudoeste do estado de Pernambuco na mesorregião São Francisco Pernambucano e faz divisa com os municípios de Afrânio, Dormentes e Lagoa Grande, no estado de Pernambuco; e Juazeiro, Sobradinho e Casa Nova, no estado da Bahia. Possui uma área de 4.561,872 $\mathrm{Km}^{2}$, está situado na região semiárida e pertence à região nordeste do Brasil.

Seu acesso pode ser tanto por via aérea quanto terrestre. Possui um aeroporto que é de importância regional sendo utilizado para acesso ao sertão nordestino. Por estrada o acesso para diferentes regiões do país pode ser realizado por 5 estradas, são elas: BR-407, BR-235, BR-428 e BR-122 (Figura 1.3).

Juntamente com Juazeiro, no estado da Bahia, faz parte da Rede Administrativa Integrada de Desenvolvimento (RIDE) do Polo Petrolina-PE e Juazeiro-BA que foi criada pela Lei Complementar $\mathrm{n}^{\mathrm{o}}$ 113, de 19 de setembro de 2001, e regulamentada pelo Decreto $\mathrm{n}^{\circ} 4.366$, de 9 de setembro de 2002. Também fazem parte da RIDE os municípios de Lagoa Grande, Orocó, Santa Maria da Boa Vista, no estado de Pernambuco; e Casa Nova, Curaçá e Sobradinho, no estado da Bahia.

\subsection{Metodologia}

\section{Instalação dos Sistemas Piloto de Recarga Artificial}

A proposição do sistema piloto foi baseada nos dados hidrogeológicos do município de Petrolina (de 526 poços) adquiridos em trabalho realizado em 2001/2002 e em dados adquiridos por Cadamuro \& Campos (2005).

No referido trabalho foram testados a eficiência de técnicas de recarga artificial direta e indireta em aquíferos fraturados no Distrito Federal. A recarga artificial direta corresponde à injeção de água diretamente por poço tubular, já a indireta corresponde ao despejo da água em caixas de infiltração instaladas em solos espessos. Para a segunda opção, foram utilizadas quatro tipos de caixas de infiltração para fins de teste de seus desempenhos. Duas sem preenchimento, sendo uma com paredes revestidas por tijolos intercalados e outra por manilha perfurada, ambas com fundo aberto com camada de $10 \mathrm{~cm}$ de cascalho no fundo para evitar a floculação de argila durante a queda d'água. E as outras duas sem revestimento, sendo uma preenchida por cascalho e outra por areia, ambas com $2 \mathrm{~m}$ de profundidade e fundo preenchido com cascalho de quartzo (CADAMURO \& CAMPOS, 2005).

Os estudos mostraram que a técnica que apresenta melhor custo/benefício é a indireta com a caixa de infiltração sem revestimento e preenchida por cascalho. Essa apresentou melhor resposta para maiores volumes de água infiltrada. As caixas sem revestimento apresentam toda a área cilíndrica da parede e do fundo como superfície de infiltração. Os autores alertam que a eficiência do sistema depende do correto dimensionamento do conjunto telhado-calha-tubulação e que o material utilizado no preenchimento deve ser inerte, possuir bom arredondamento, boa esfericidade e porosidade efetiva maior que 40\% (CADAMURO \& CAMPOS, 2005). 


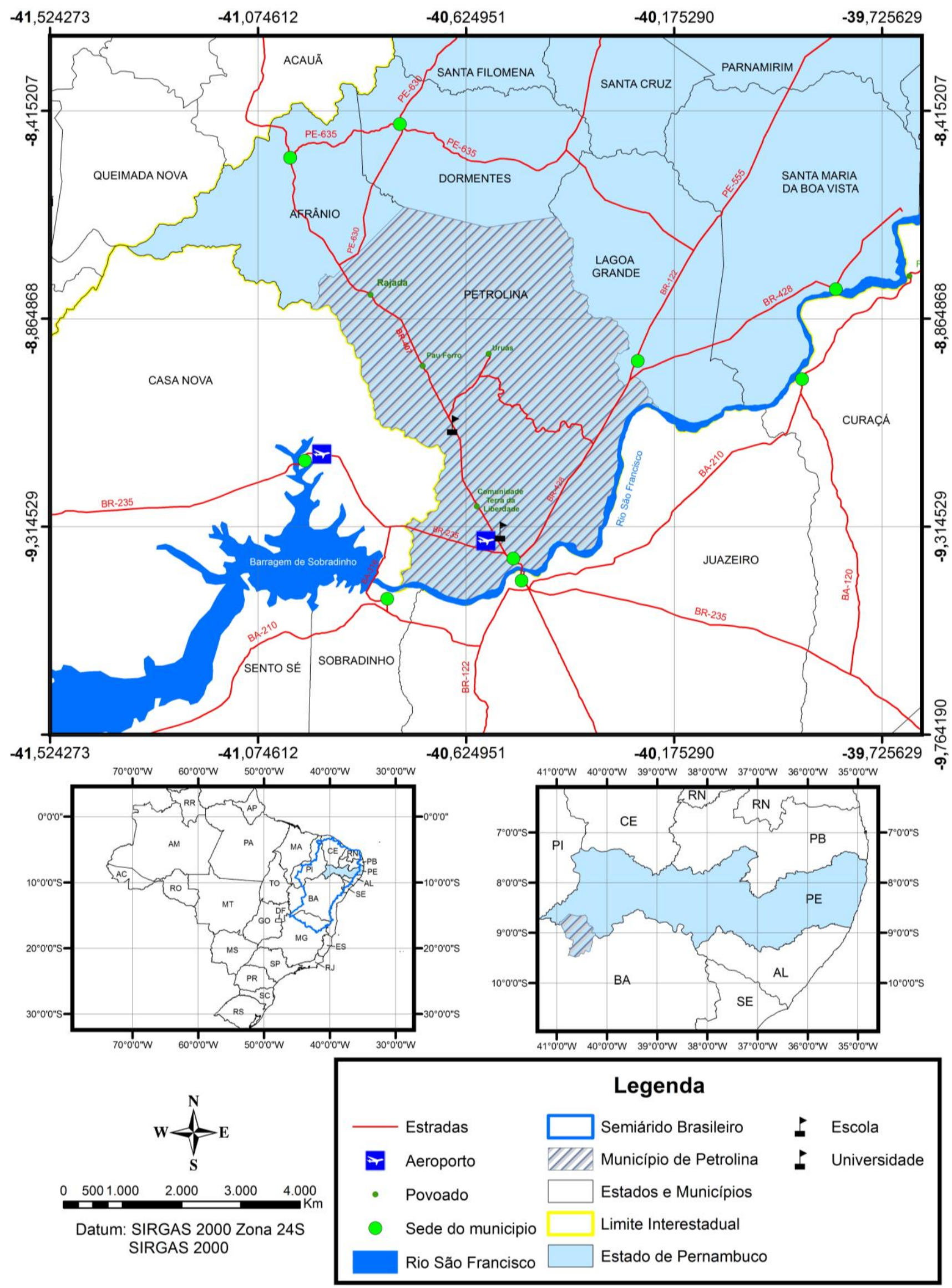

Figura 1.3 - Mapa de localização do município de Petrolina-PE. 
Com base nisso, o sistema elaborado pelo Projeto RECARFRAT é constituído por calhas para coleta de água de telhados, uma trincheira de recarga (caixa de infiltração sem revestimento e preenchida por cascalho) e um poço de monitoramento. O objetivo é a coleta de água da chuva pelas calhas e transporte desta para as trincheiras de recarga e consequentemente para o aquífero. A trincheira deve ser construída com profundidade suficiente para passar pelo solo e atingir a rocha fresca. Foram desenvolvidos dois tipos de poços de monitoramento, sendo um para solos rasos e outro para saprólitos profundos ou áreas de acumulação de aluviões arenosos (Figuras 1.4 e 1.5).

Inicialmente foi prevista a construção de três sistemas pilotos. As áreas para a sua locação foram determinadas com a utilização de técnicas de sensoriamento remoto, análise neotectônica e geofísica pela equipe do projeto RECARFRAT. Os estudos para locação dos sistemas piloto foram realizados antes do início desse estudo de mestrado. Por isso, somente seus pontos chave serão brevemente citados.

As análises de sensoreamento remoto foram feitas em imagens gratuitas utilizando o Google Earth para auxiliarem na definição da logística necessária para locação dos pilotos. Foram traçados os principais lineamentos da área incluindo lineamentos de drenagens. Neste sentido, foram localizadas áreas com as seguintes características: presença de áreas cobertas (casas ou aglomerados de casas) situadas próximas aos lineamentos (possíveis zonas de fraturas), áreas com lineamentos (possíveis zonas de fraturas) a jusante das áreas com coberturas, presença de poços tubulares nos mesmos sítios e presença de águas salinizadas com diferentes teores de Sólidos Totais Dissolvidos (TDS). A proximidade dos poços perfurados com edificações permite que os mesmos possam ser utilizados pela população posteriormente ao término dos estudos.

Em seguida foi realizado o levantamento geofísico terrestre com eletrorresistividade e GPR nas áreas pré-selecionadas pelas técnicas de sensoreamento remoto. Apesar da espessura do solo na região ser pequena, sobre as zonas de fratura e de cisalhamento nota-se uma maior espessura das coberturas pedológicas dificultando assim o mapeamento superficial das fraturas.

As investigações geofísicas definiram as características geométricas dos aquíferos, distribuição espacial do fraturamento, espessura do manto de intemperismo e de possíveis coberturas sedimentares nas áreas. O emprego de eletrorresistividade a estudos hidrogeológicos em terrenos fissurados tem como objetivo principal a identificação das principais zonas de fraturamento. Estas fraturas preenchidas ou não, mostram contraste elétrico relevante quando comparadas às rochas. O arranjo utilizado foi o dipolo-dipolo (DD) e Wenner Schlumberger (WS), com espaçamento entre os eletrodos de 5 metros. A máxima profundidade de investigação foi de 40 metros. A aplicação do GPR a estudos hidrogeológicos apresenta bons resultados na identificação de zonas de fraturamento. As seções de GPR foram efetuadas a cada 5 metros de distância, com o objetivo de localizar as principais zonas de cisalhamento, bem como toda a estruturação da cobertura geológica. Estes perfis foram analisados em 2D, e interpolados com o objetivo de obter um volume tridimensional da área. 


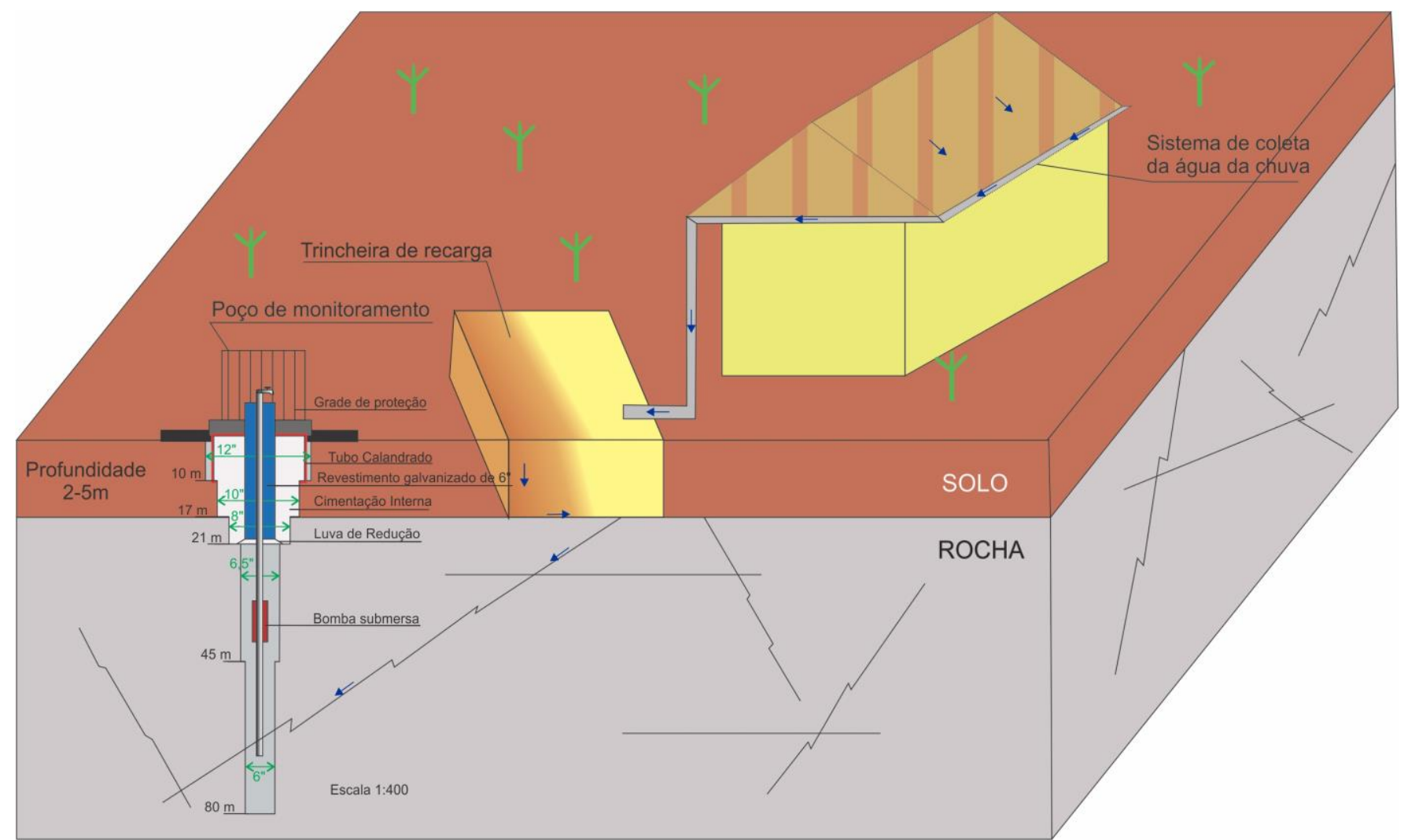

Figura 1.4 - Esquema do Sistema Piloto de Recarga Artificial com poço de monitoramento para solos rasos.

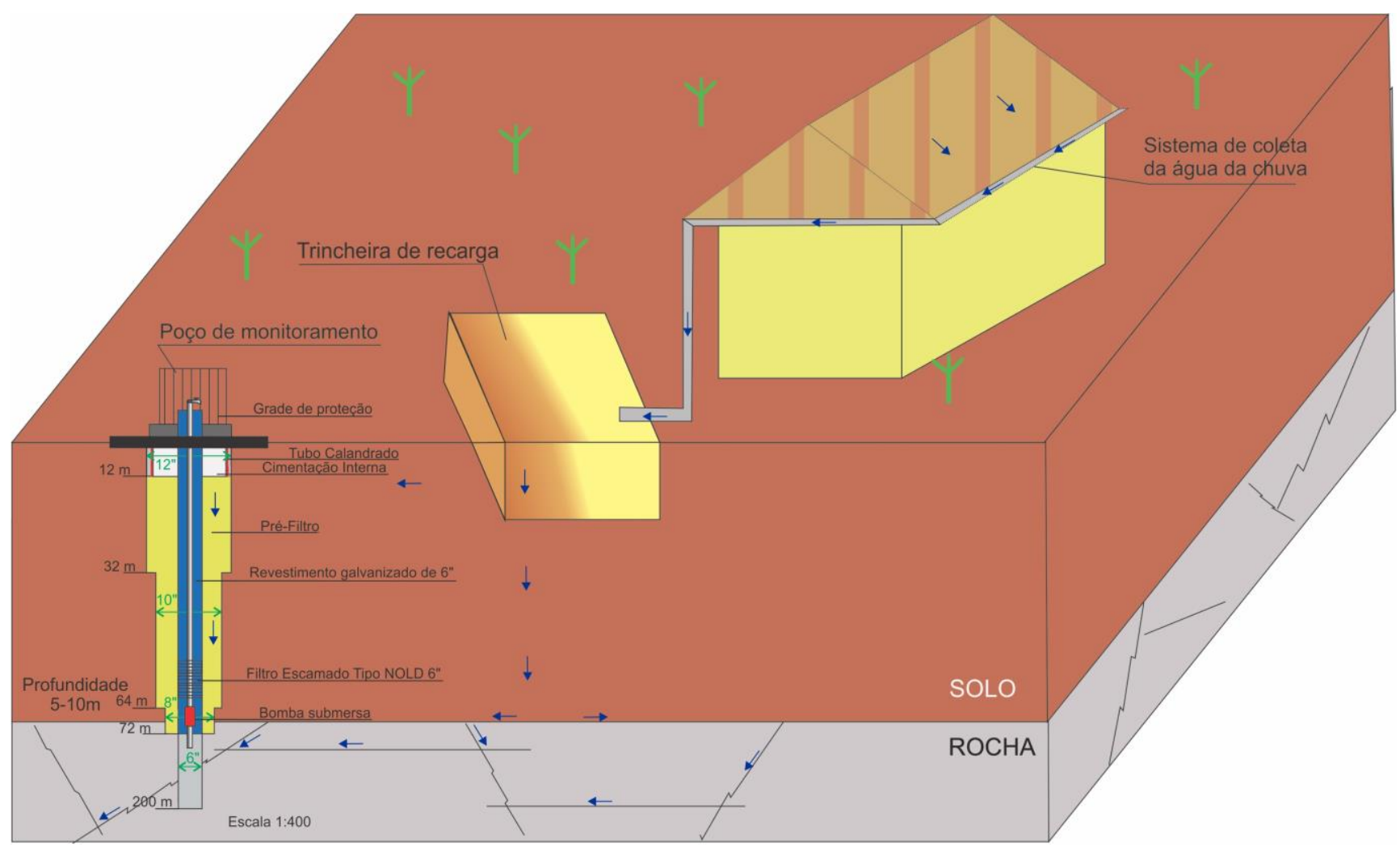

Figura 1.5 - Esquema do Sistema Piloto de Recarga Artificial com poço de monitoramento para solos profundos ou área de acumulação de aluviões arenosos. 
Uma das áreas selecionadas para fazer a geofísica foi no campus da Universidade Federal do Vale do São Francisco (UNIVASF). Nessa área, foram obtidas 10 seções de eletrorresistividade, cada uma com 145 metros de comprimento, espaçadas a cada 5 metros. Os caminhamentos elétricos foram executados com os arranjos dipolo-dipolo (DD) e Wenner Schlumberger (WS). Na aquisição de dados foi usado um sistema elétrico multieletródico (Syscal PRO), com 30 eletrodos. Os dados foram adquiridos paralelos e equi-espaçados, sendo posteriormente concatenados como dados 3D (Quase-3D). O conjunto de dados do arranjo DD correspondeu a um bloco com 2678 pontos de investigação, ao passo que no arranjo WS foram investigados 1542 pontos. A inversão dos dados de elétrica Quase-3D foi realizada no software Res3dinv até a quinta iteração. Os erros RMS foram de 18\% (DD) e 7,5\% (WS). Nas aquisições de GPR na UNIVASF foi utilizado o sistema SIR3000 acoplado a uma antena blindada de 200 MHz. Os dados foram processados no Módulo 2D do software REFLEXW@ versão 5.5, e o principal objetivo do processamento foi realçar as camadas de solo. Durante o processamento foi determinada a chegada da primeira onda (ajuste do tempo zero); aplicação de ganho do tipo decaimento de energia, filtragens $1 \mathrm{D}$ e $2 \mathrm{D}$, e migração de difrações (diffraction stack). A velocidade do meio foi obtida através de ajuste hiperbólico de pequenas difrações encontradas nos perfis de GPR (0,11 m/ns) (PÁDUA et al., 2013).

Os dados obtidos com a geofísica foram apresentados no $13^{\circ}$ Congresso Internacional da Sociedade Brasileira de Geofísica em 2013 (PÁDUA et al., 2013).

Dos 3 locais selecionados com a geofísica e o sensoreamento remoto, em 2 áreas durante a perfuração dos poços não foram encontradas vazões suficientes para a pesquisa. Dessa forma, foram feitos acordos para a utilização de 2 poços particulares que haviam sido recentemente perfurados. Um na área da empresa RKF Mudas que trabalha com a produção de mudas de uva e outro na fazenda do Sr. Jair que possui criação de animais e pequena área de plantação. O poço que obteve sucesso na perfuração está localizado próximo a Escola Municipal Dr. José Araújo de Souza no quilômetro 90 da BR-407. A Tabela 1.1 e a Figuras 1.6 apresentam a localização dos Sistemas Piloto de Recarga Artificial com suas devidas denominações. Essas denominações serão utilizadas no decorrer da dissertação.

Devido a problemas financeiros relacionados ao Projeto RECARFRAT não foi possível à construção dos sistemas em tempo hábil para que os testes fossem realizados de maneira natural com a água da chuva. Dessa forma, os sistemas foram testados durante trabalhos de campo realizados em Dez/2014 e Mar/2015 com o uso de água proveniente de caminhões pipa, abastecidos com água do Rio São Francisco e do canal de irrigação. Durante os testes foram monitorados o volume de água injetado e o tempo de infiltração, além de serem coletadas amostras para determinação de condutividade elétrica, $\mathrm{pH}$, Eh e isótopos estáveis ( $\mathrm{D}$ e $\mathrm{O}$ ), tanto das águas dos aquíferos, quanto das águas utilizadas na recarga.

Tabela 1.1 - Localização dos Sistemas Piloto de Recarga Artificial.

\begin{tabular}{|c|c|c|c|c|c|}
\hline \multirow{2}{*}{ Nome } & \multicolumn{3}{|c|}{ Coordenada UTM Zona 24L } & \multirow{2}{*}{ Localização } & \multirow{2}{*}{ Referência } \\
\hline & $\mathrm{X}$ & $\mathbf{Y}$ & Altitude & & \\
\hline $\begin{array}{llll}\text { Sistema Piloto } & \text { da } & \text { Escola } \\
\text { Municipal } & & & \\
\end{array}$ & 0318467 & 8994251 & $428 \mathrm{~m}$ & BR-407 Km 90 & $\begin{array}{l}\text { Atrás da Escola Municipal } \\
\text { Dr. José Araújo de Souza }\end{array}$ \\
\hline Sistema Piloto da RKF mudas & 0327777 & 8963947 & $388 \mathrm{~m}$ & BR-235 & $\begin{array}{l}\text { Próximo ao Aeroporto de } \\
\text { Petrolina }\end{array}$ \\
\hline Sistema Piloto da Fazenda do Jair & 0315526 & 9000363 & $452 \mathrm{~m}$ & BR-407 Km 84 & Na Fazenda do Senhor Jair \\
\hline
\end{tabular}



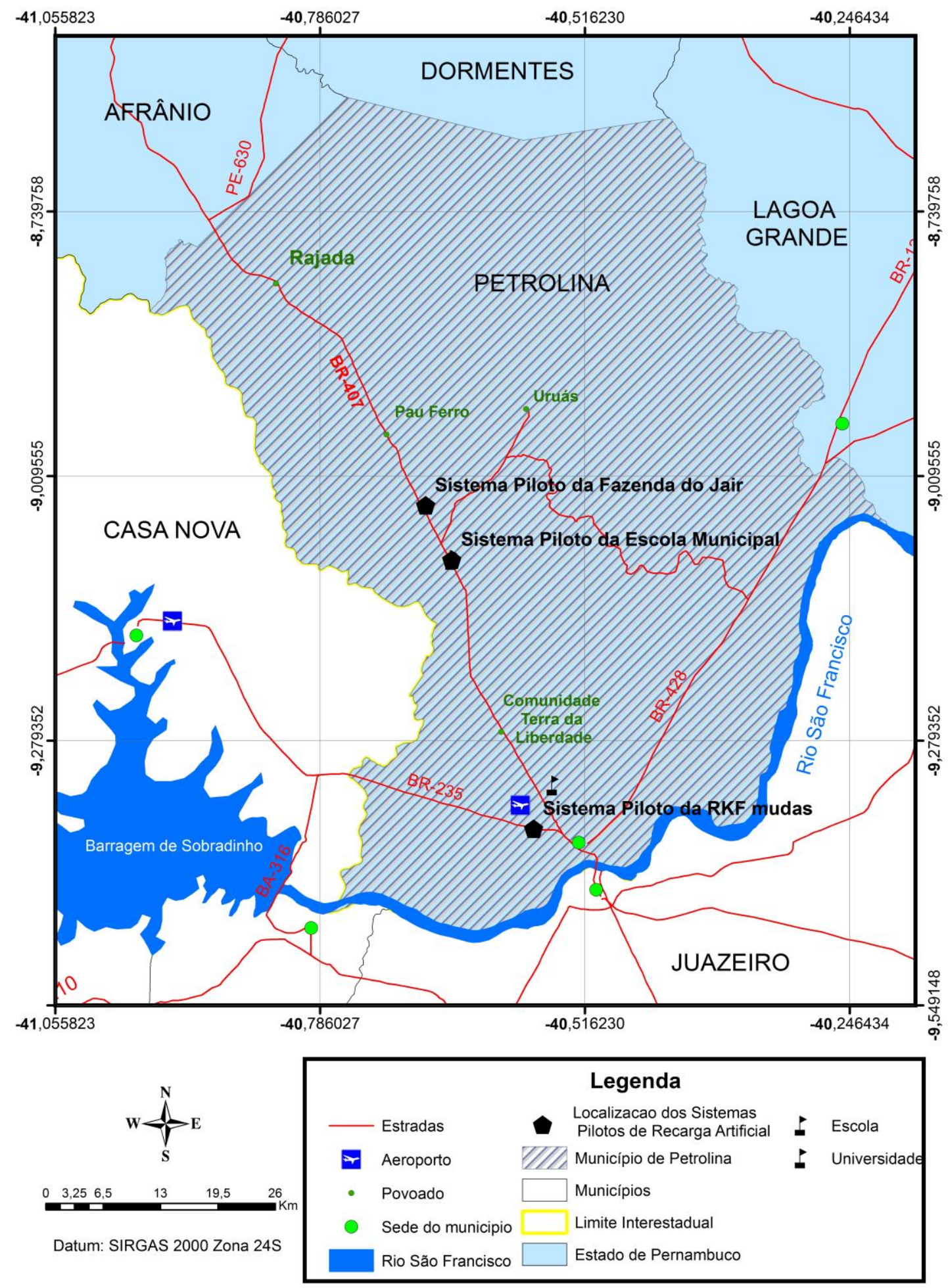

Figura 1.6 - Mapa de localização dos Sistemas Piloto de Recarga Artificial.

As Figuras 1.7 e 1.8 mostram os perfis construtivos dos poços de monitoramento dos sistemas piloto da Escola Municipal e da Fazenda do Jair, respectivamente. Infelizmente não foi possível obter informações sobre o perfil construtivo do poço de monitoramento do Sistema Piloto da RKF mudas, pois o poço já estava pronto quando foi feito o acordo para sua utilização sendo que não foi possível acompanhar a perfuração do mesmo. E a Figura 1.9 mostra fotografias dos 3 sítios retiradas durante os trabalho de campo. 


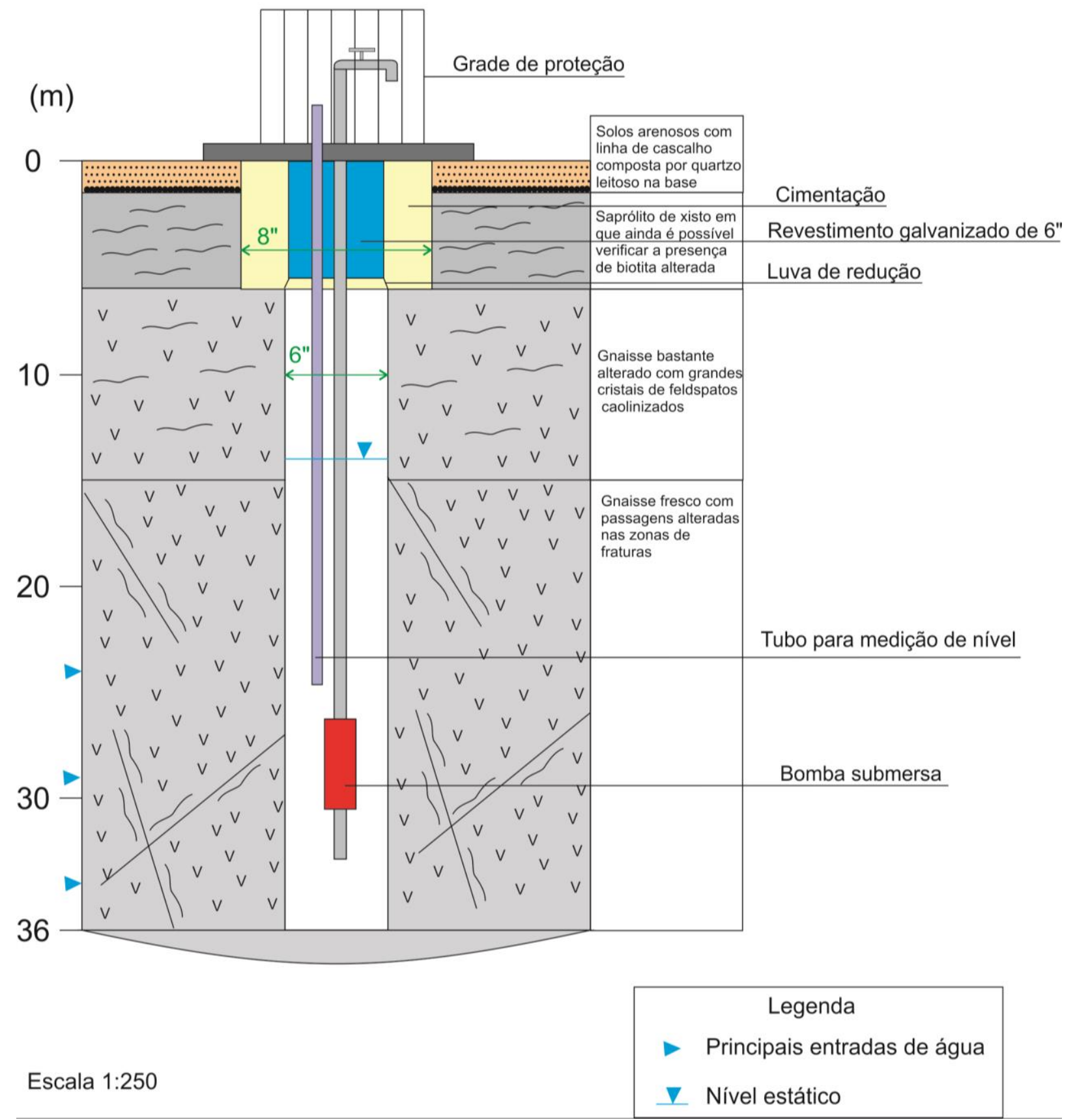

Figura 1.7 - Perfil construtivo do poço de monitoramento do Sistema Piloto da Escola Municipal. O poço possui 36 metros de profundidade e apresentou uma vazão aproximada de $4.360,7 \mathrm{~L} / \mathrm{h}$. 


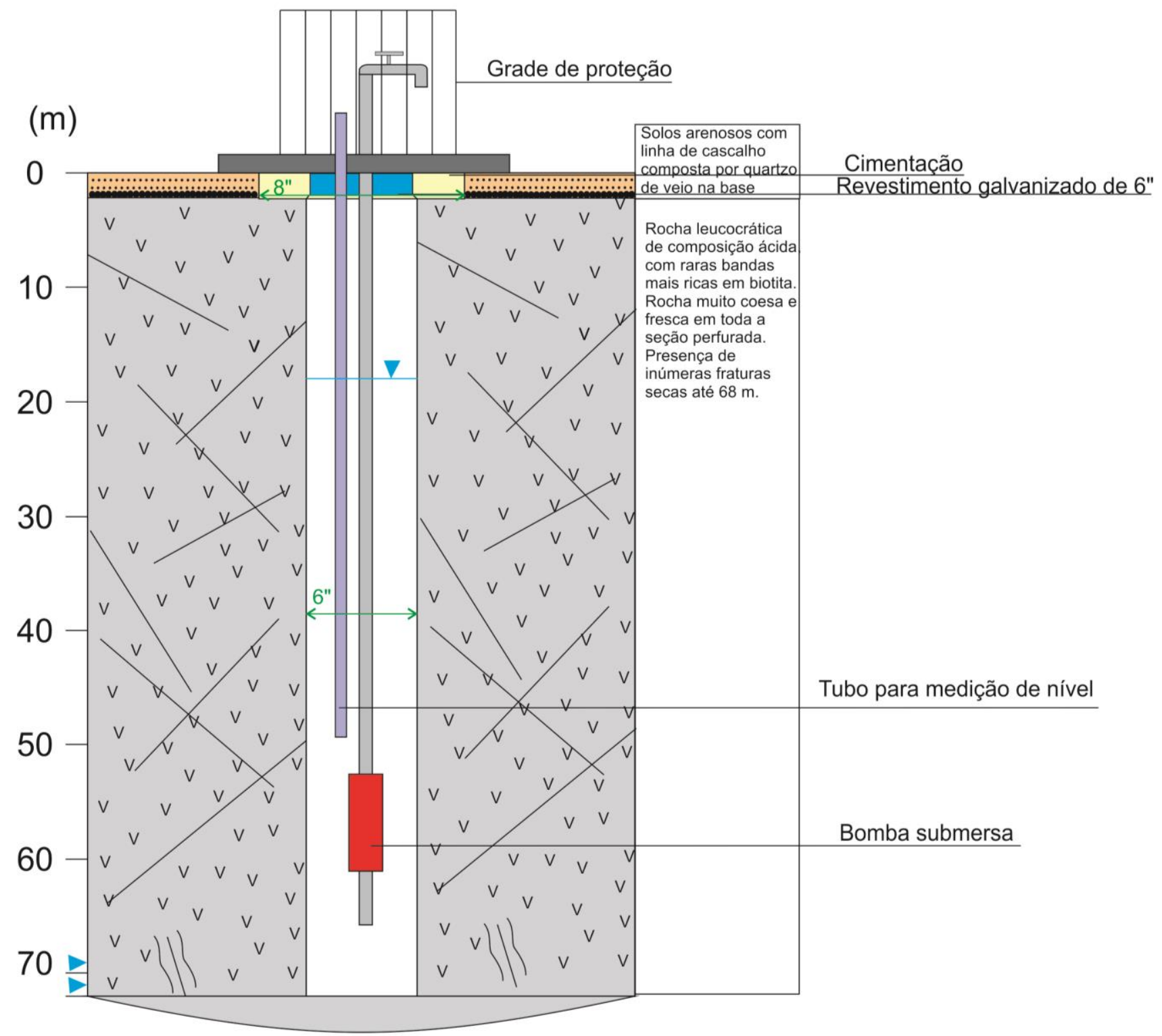

\section{Legenda}

Escala 1:500

- Principais entradas de água

$\nabla$ Nível estático

Figura 1.8 - Perfil construtivo do poço de monitoramento do Sistema Piloto da Fazenda do Jair. O poço possui 72 metros de profundidade e apresentou uma vazão aproximada de $4.551,2 \mathrm{~L} / \mathrm{h}$. 

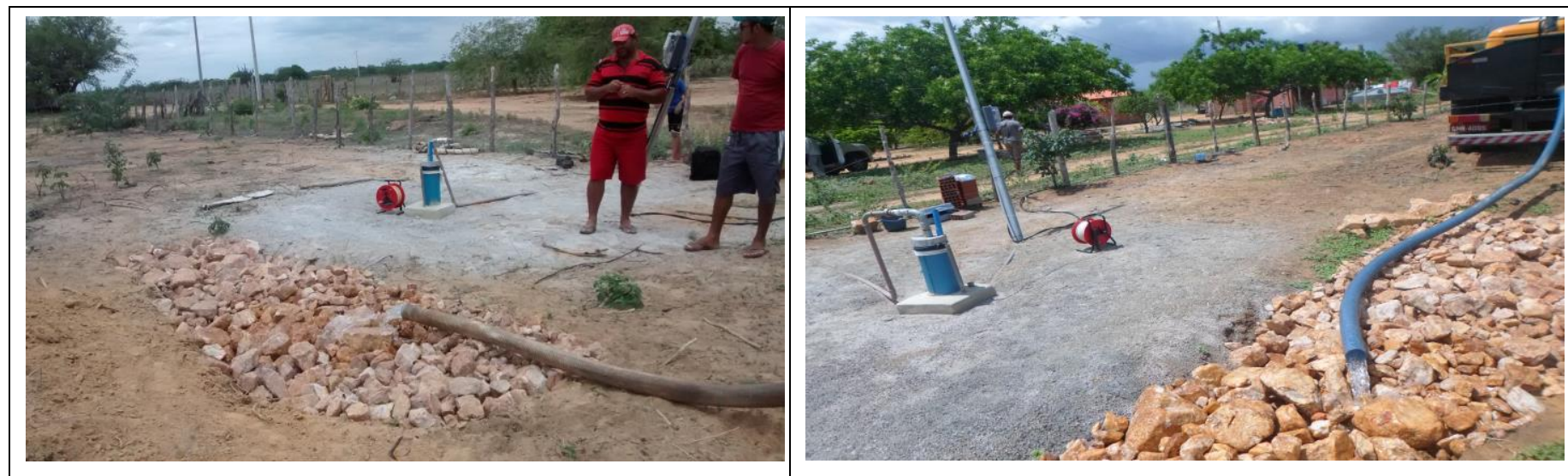

Sistema Piloto da Fazenda do Jair

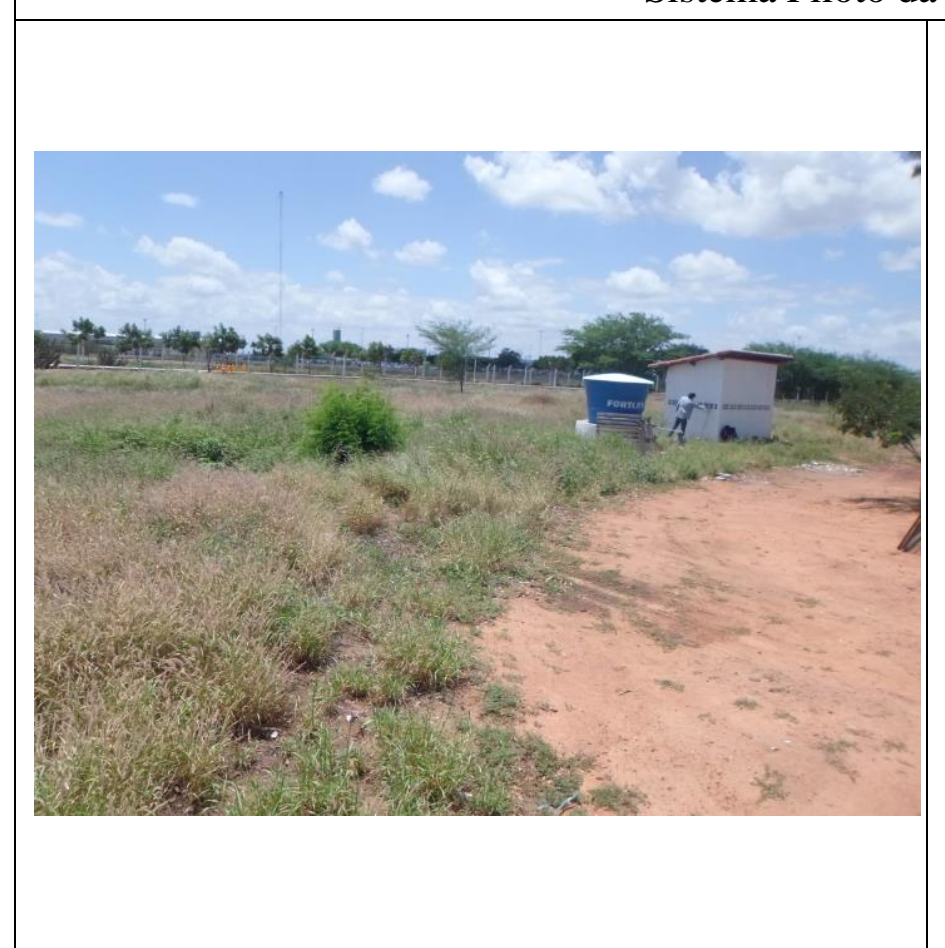

Sistema Piloto da RKF mudas
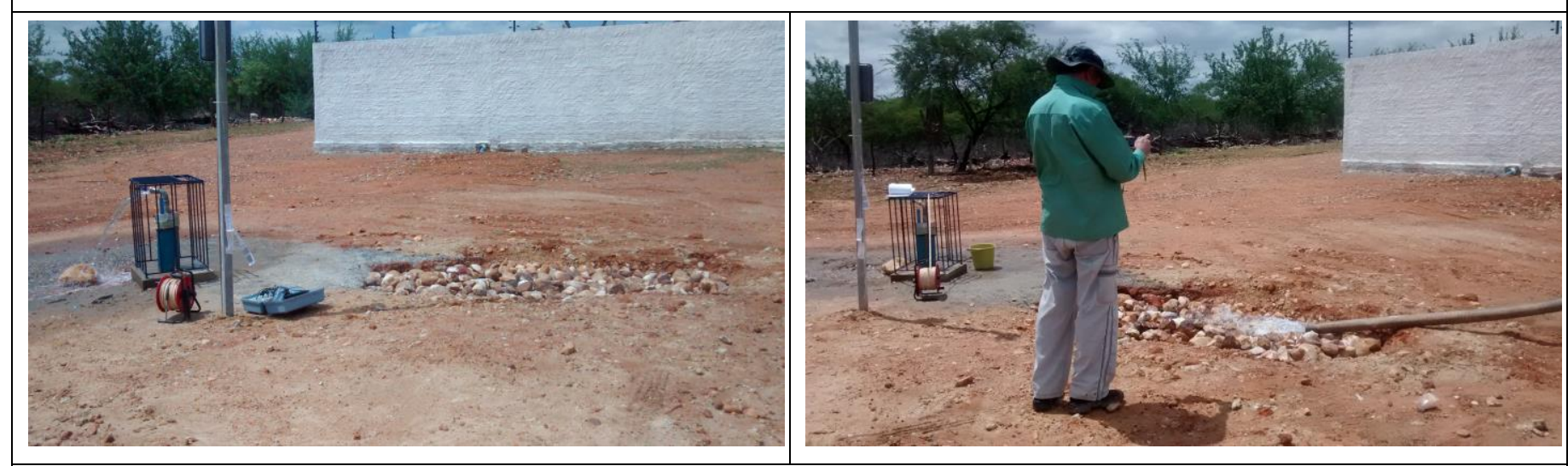

Sistema Piloto da Escola Municipal

Figura 1.9 - Fotos dos Sistemas Piloto de Recarga Artificial no município de Petrolina-PE. 


\section{Estudos Isotópicos}

No presente estudo foram utilizados os traçadores isotópicos naturais: Oxigênio $\left({ }^{18} \mathrm{O}\right.$ e ${ }^{16} \mathrm{O}$ ), Hidrogênio (H e D) e a razão ${ }^{87} \mathrm{Sr} /{ }^{86} \mathrm{Sr}$. Enquanto que as variações isotópicas de oxigênio e hidrogênio são afetadas por processos físicos que modificam a razão isotópica desses elementos (ex. temperatura, difusão, condensação), as razões isotópicas de estrôncio permanecem inalteradas frente a esses processos.

Foram realizadas análises isotópicas de $\mathrm{O}$ e $\mathrm{H}$ em poços distribuídos pelo município e com diferentes quantidades de sólidos totais dissolvidos para caracterização regional da área e para estudo da origem das águas subterrâneas.

As análises isotópicas também foram utilizadas para estudo da mistura na recarga artificial. Uma quantidade significativa de água (do Rio São Francisco e do canal de irrigação) com composição isotópica de $\mathrm{O}$ e $\mathrm{H}$ conhecidos foi colocada nos Sistemas Piloto de Recarga Artificial. A mistura com as águas subterrâneas gera alterações no seu sinal isotópico (também previamente conhecidas). Nesse caso, foi privilegiado águas com composições isotópicas significativamente diferentes da água infiltrada naturalmente, possibilitando assim um maior contraste isotópico com a água subterrânea local.

De maneira complementar, foi realizada a análise isotópica de $\mathrm{D}$ e $\mathrm{O}$ em vários pontos de um canal de irrigação que tem uma extremidade próxima ao povoado de Uruás e captação no Rio São Francisco. O objetivo é estudar o comportamento da evaporação nas águas superficiais do município, pois esse processo atua de maneira direta nas águas de recarga dos aquíferos.

As análises isotópicas de oxigênio e hidrogênio foram realizadas no Laboratório de Geocronologia da Universidade de Brasília, sendo que as de $\delta \mathrm{D}$ e $\delta^{18} \mathrm{O}$ em água foram aferidas no aparelho da marca PICARRO modelo L2120-i $\delta \mathrm{D}$ e $\delta^{18} \mathrm{O}$ Analyzer (adquirido pelo Projeto RECARFRAT) que utiliza o método de medição de espectrometria de massa com separação a laser.

As análises da razão ${ }^{87} \mathrm{Sr} /{ }^{86} \mathrm{Sr}$ foram utilizadas para analisar a interação água-rocha, tempo de residência da água subterrânea, recarga e o fluxo. Foram realizadas no Laboratório de Geocronologia da Universidade de Brasília, em água e em rocha, no espectrômetro TIMS (espectrômetro de massa por ionização térmica) do modelo Triton Plus.

Datações com auxílio do método carbono 14 e trítio também foram realizadas em amostras de águas com diferentes quantidades de sólidos totais dissolvidos para estudo da origem e tempo de residência das águas subterrâneas. 


\section{CAPÍTULO 2}

\section{SÍNTESE SOBRE O MEIO FÍSICO E ASPECTOS SOCIOECONÔMICOS}

\subsection{Hidrografia}

O conceito de Região Hidrográfica foi implementado em 2003 através da Resolução n ${ }^{\circ}$ 32/2003 do Conselho Nacional de Recursos Hídricos. Segundo este documento, Região Hidrográfica (RH) é: “o espaço territorial brasileiro compreendido por uma bacia, grupo de bacias, ou subbacias hidrográficas contíguas com características naturais, sociais e econômicas homogêneas ou similares, com vista a orientar o planejamento e o gerenciamento dos recursos hídricos" (ANA, 2015b).

A Região Hidrográfica do São Francisco possui aproximadamente $638.466 \mathrm{Km}^{2}$ de área, o correspondente a aproximadamente 7,5\% do território brasileiro (Figura 2.1). Esta inserida em estados das regiões sudeste, centro-oeste e nordeste do Brasil, sendo eles: Bahia, Minas Gerais, Pernambuco, Alagoas, Sergipe, Goiás e Distrito Federal. O Rio São Francisco nasce em Minas Gerais e percorre cerca de $2.800 \mathrm{Km}$ até a chegada ao Oceano Atlântico entre Alagoas e Sergipe. Nesse percurso foi dividido em quatro unidades hidrográficas: Alto São Francisco, Médio São Francisco, Sub-médio São Francisco e Baixo São Francisco (Tabela 2.1). Os principais rios da região são: São Francisco, das Velhas, Grande, Verde Grande, Paracatu, Urucuia, Paramirim, Pajeú, Preto e Jacaré. A densidade populacional média na Região Hidrográfica é de 22,4 hab./Km², correspondente a média brasileira (ANA, 2015b).

Aproximadamente $58 \%$ da área da RH São Francisco esta localizada na região do semiárido brasileiro. Sendo que nessa porção somente três municípios tem população superior a 100.000 habitantes, são eles: Petrolina-PE, Arapiraca-AL e Juazeiro-BA. Segundo dados do Instituto Nacional de Meteorologia (INMET), a precipitação anual nessa área é de $1.003 \mathrm{~mm}$, muito inferior à média nacional que é de $1.761 \mathrm{~mm}$. A questão da escassez de recursos hídricos se acentua na porção correspondente ao semiárido nordestino, onde o Rio São Francisco e seus afluentes exercem papel fundamental no abastecimento de água (ANA, 2015b).

A demanda hídrica da Região Hidrográfica do São Francisco é predominantemente representada pela irrigação (77\%), seguido da demanda urbana (11\%), industrial (7\%), animal (4\%) e rural (1\%). Estima-se uma área total irrigada de 626.000 hectares (ano base 2012), onde podem se destacar os polos de Juazeiro-Petrolina (fruticultura), Barreiras (soja) e bacia do Rio Preto/Paracatu (Figura 2.2) (ANA, 2015b).

O município de Petrolina está localizado na unidade hidrográfica Sub-médio São Francisco na porção correspondente ao semiárido nordestino. Juntamente com Juazeiro forma um dos principais aglomerados urbanos da Região Hidrográfica do São Francisco. 


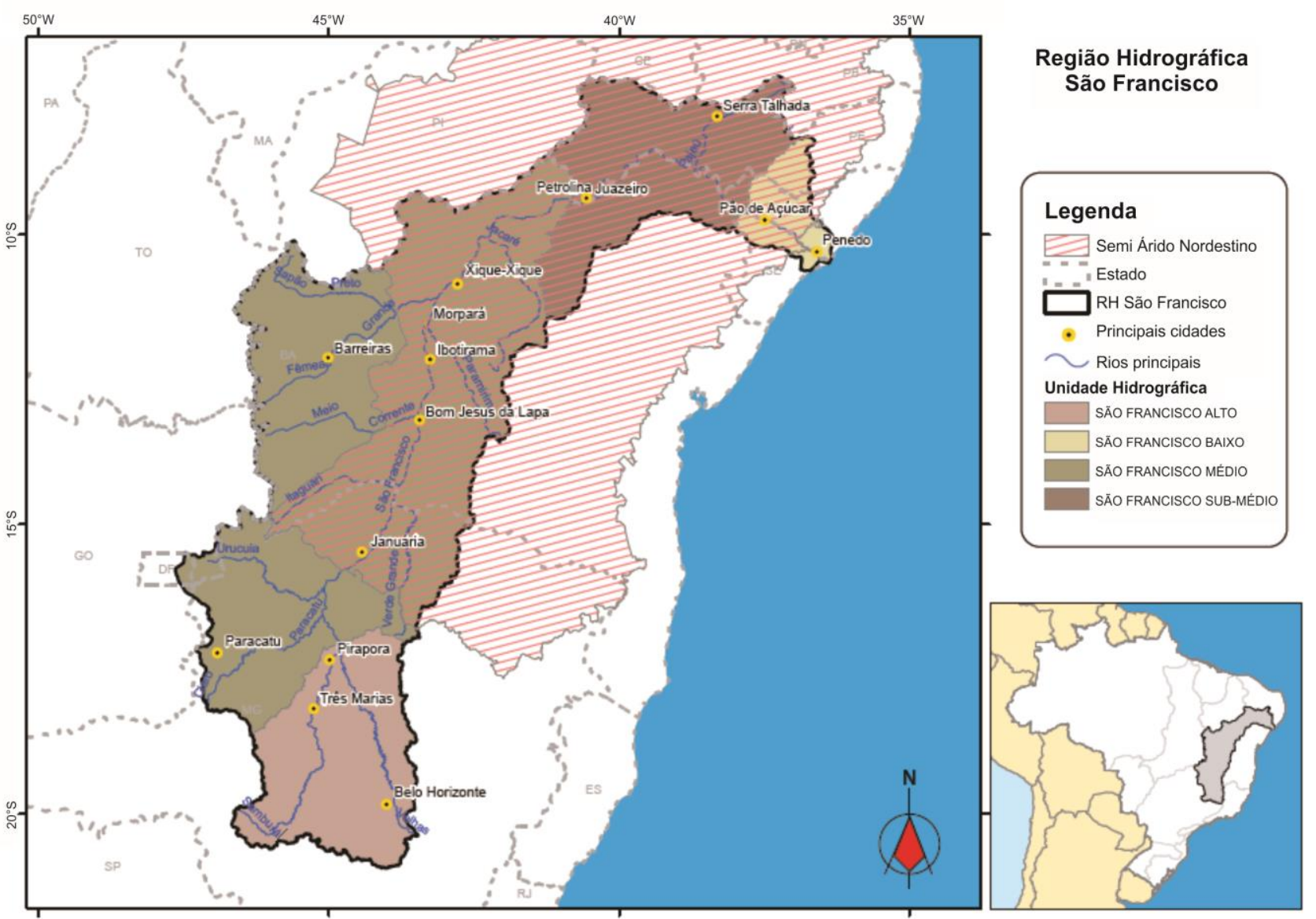

Figura 2.1 - Região Hidrográfica do São Francisco com as principais cidades representadas (Adaptado de ANA, 2015b).

Tabela 2.1 - Caracterização das Unidades Hidrográficas da RH São Francisco. Em destaque a unidade na qual o município de Petrolina está localizado (Adaptado de IBGE, 2010 Input ANA, 2015b).

\begin{tabular}{|c|c|c|c|c|c|}
\hline $\begin{array}{c}\text { Unidade } \\
\text { Hidrográfica }\end{array}$ & Área (ha) & $\begin{array}{c}\text { Número de } \\
\text { Sedes } \\
\text { Municipais }\end{array}$ & $\begin{array}{c}\text { População } \\
\text { Urbana }\end{array}$ & $\begin{array}{c}\text { População } \\
\text { Rural }\end{array}$ & $\begin{array}{c}\text { População } \\
\text { Total }\end{array}$ \\
\hline $\begin{array}{c}\text { Alto São } \\
\text { Francisco }\end{array}$ & 100.085 & 151 & 6.706 .784 & 368.803 & 7.075 .587 \\
\hline $\begin{array}{c}\text { Médio São } \\
\text { Francisco }\end{array}$ & 402.491 & 156 & 2.189 .862 & 1.349 .447 & 3.539 .309 \\
\hline $\begin{array}{c}\text { Sub-médio } \\
\text { São Francisco }\end{array}$ & 110.473 & 73 & 1.340 .371 & 893.532 & 2.233 .903 \\
\hline $\begin{array}{c}\text { Baixo São } \\
\text { Francisco }\end{array}$ & 25.417 & 72 & 775.351 & 665.803 & 1.441 .154 \\
\hline $\begin{array}{c}\text { RH São } \\
\text { Francisco }\end{array}$ & 638.466 & 452 & 11.012 .368 & 3.277 .585 & 14.289 .953 \\
\hline
\end{tabular}




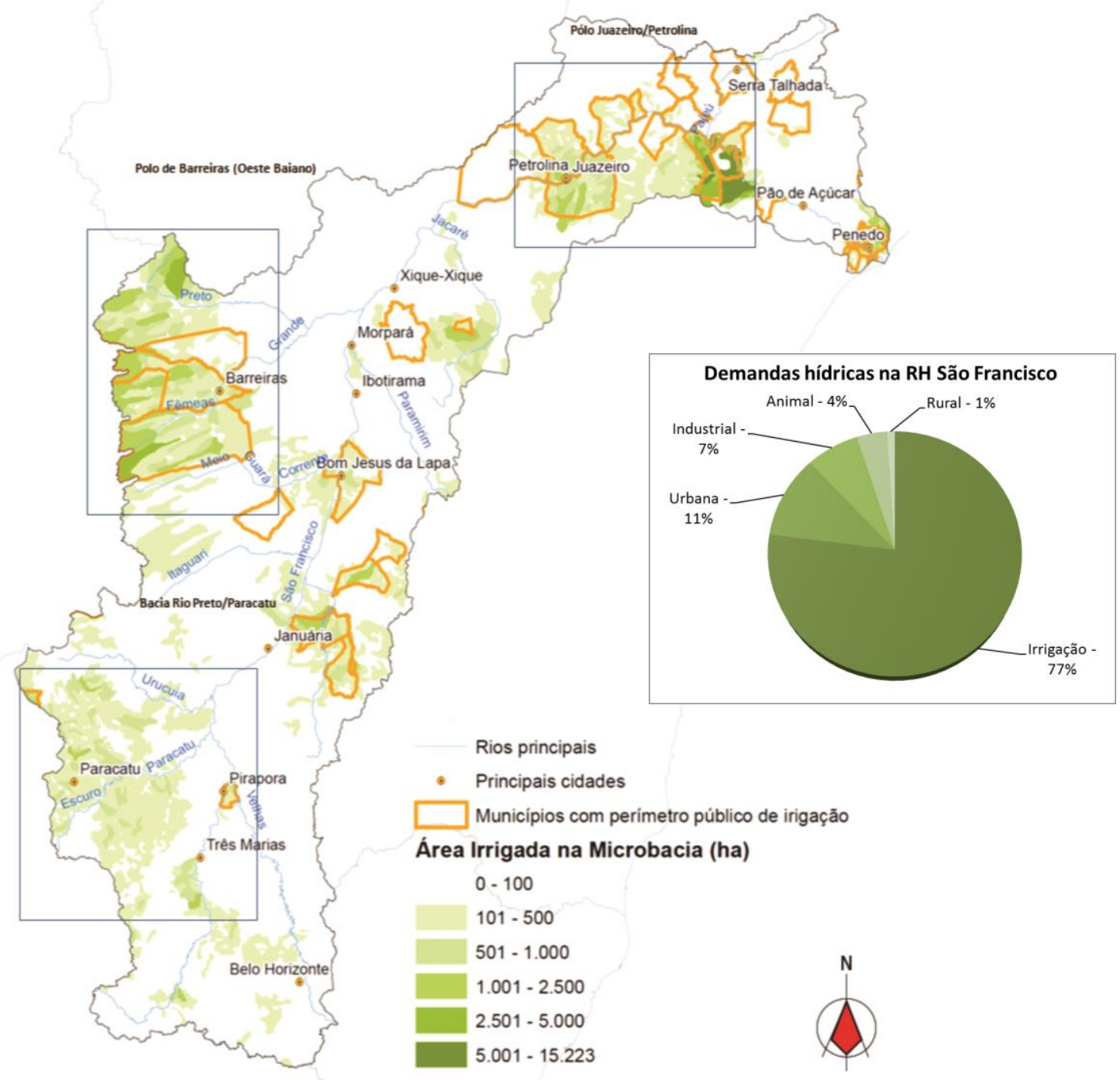

Figura 2.2 - Principais polos de irrigação da Região Hidrográfica do São Francisco juntamente com estimativas de áreas irrigadas por microbacia (ha). A direita um gráfico representando as demandas hídricas presentes na RH (Adaptado de ANA, 2015b).

\subsection{Geomorfologia}

O município de Petrolina está localizado na unidade de paisagem Depressão Sertaneja que se localiza em torno do Planalto Sertanejo. As características desta unidade estão relacionadas com as rochas cristalinas e sedimentares que ocorrem na região.

As depressões são esculpidas por processos denudacionais, ou circundenudacionais, ao longo do Terciário e Quaternário, por meio da alternância de fases erosivas em climas secos e úmidos. São superfícies rebaixadas e aplainadas e constituem superfícies de erosão ou de aplainamento do relevo que variam de colinas baixas e médias até relevos de topos planos ou formato levemente convexo. É comum a presença de inselbergs que são morros elevados caracterizados como relevos residuais que estão associados à litologias mais resistentes aos processos erosivos como rochas metamórficas e ígneas intrusivas (STORANI \& PEREZ FILHO, 2008).

A Depressão Sertaneja foi dividida em 11 unidades geoambientais, sendo que 10 ocorrem em Petrolina e estão expressas na Figura 2.3 (SILVA \& FERREIRA, 2003). As unidades geoambientais estão descritas na Tabela 2.2. 


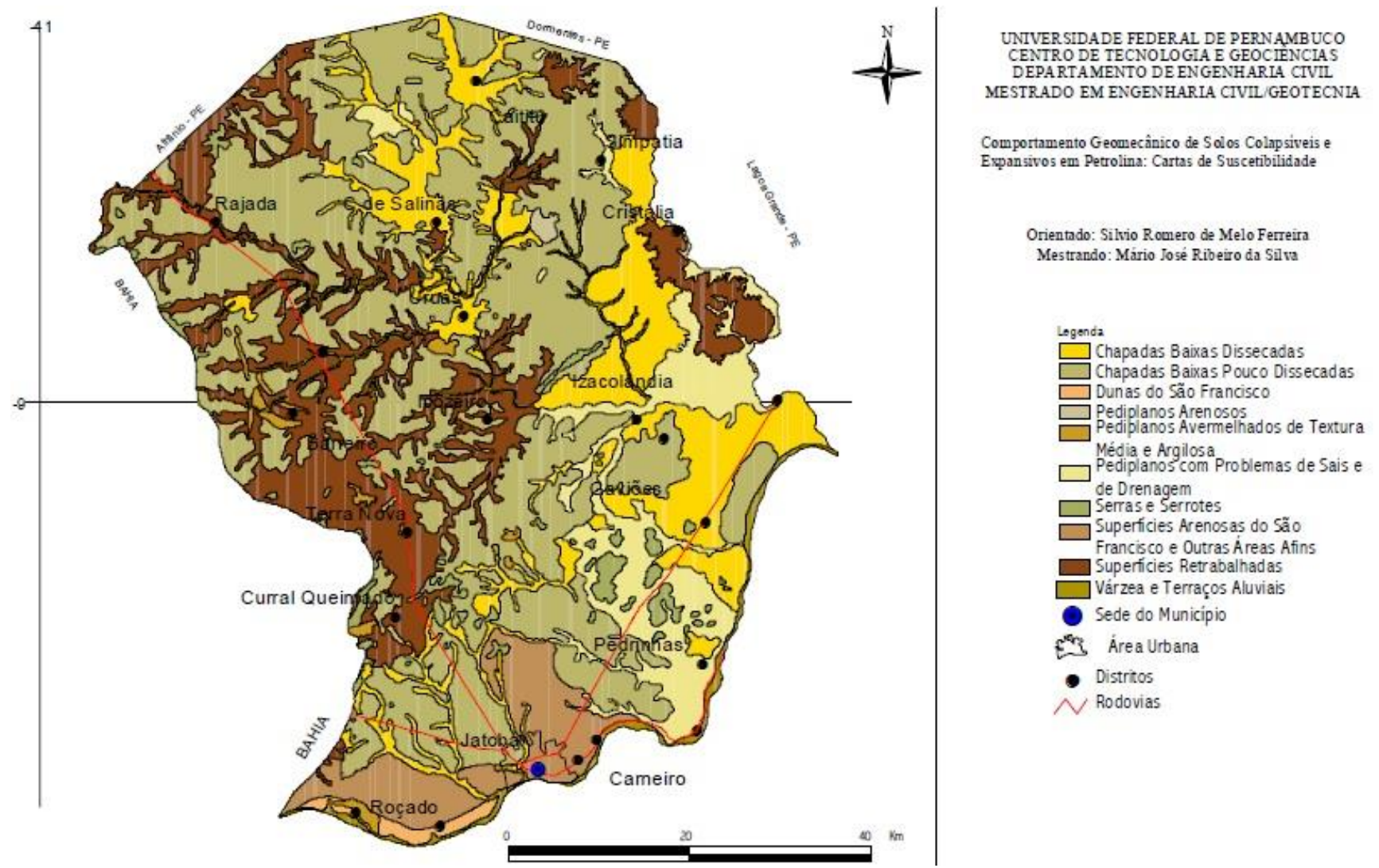

Figura 2.3 - Mapa de geomorfologia de Petrolina (SILVA \& FERREIRA, 2003).

Tabela 2.2 - Tabela de descrição das unidades geoambientais presentes no município de Petrolina-PE (SILVA \& FERREIRA, 2003).

\begin{tabular}{|c|c|c|c|c|c|}
\hline & $\begin{array}{c}\text { Unidade } \\
\text { Geoambiental }\end{array}$ & Ocorrência & Relevo & Solos & $\begin{array}{l}\text { Área do } \\
\text { município }\end{array}$ \\
\hline 1 & $\begin{array}{l}\text { Chapada pouco } \\
\text { dissecadas }\end{array}$ & Topos planos das chapadas baixas & & $\begin{array}{l}\text { Latossolos (amarelo e } \\
\text { vermelhos) e } \\
\text { podzólicos (amarelo e } \\
\text { vermelho-amarelo) }\end{array}$ & $33 \%$ \\
\hline 2 & Várzeas e terraços & Ao longo das calhas dos rios & $\begin{array}{c}\text { Superfícies } \\
\text { aplainadas }\end{array}$ & Solos aluviais & $4 \%$ \\
\hline 3 & $\begin{array}{l}\text { Chapadas baixas } \\
\text { dissecadas }\end{array}$ & & $\begin{array}{l}\text { Suave ondulado } \\
\text { a ondulado }\end{array}$ & $\begin{array}{l}\text { Podzólicos (amarelo e } \\
\text { vermelho-amarelo) }\end{array}$ & $17 \%$ \\
\hline 4 & Pediplanos arenosos & Superfícies claras & & Regossolos arenosos & $<1 \%$ \\
\hline 5 & $\begin{array}{c}\text { Superfícies } \\
\text { retrabalhadas }\end{array}$ & Áreas de intenso retrabalhamento & $\begin{array}{c}\text { Plano a } \\
\text { ondulado }\end{array}$ & $\begin{array}{c}\text { Podzólicos vermelho- } \\
\text { amarelo }\end{array}$ & $33 \%$ \\
\hline 6 & $\begin{array}{l}\text { Pediplanos } \\
\text { avermelhados de } \\
\text { textura média e } \\
\text { argiloso }\end{array}$ & & $\begin{array}{l}\text { Plano a suave } \\
\text { ondulado }\end{array}$ & $\begin{array}{l}\text { Vertissolos, cambissolo } \\
\text { e podzólicos vermelho- } \\
\text { escuro }\end{array}$ & $0,5 \%$ \\
\hline 7 & $\begin{array}{l}\text { Pediplanos com } \\
\text { problemas de sais e } \\
\text { drenagem } \\
\end{array}$ & Acompanha rios e riachos & Plano abaciado & Planossolo solódicos & $7 \%$ \\
\hline 8 & $\begin{array}{l}\text { Dunas do São } \\
\text { Francisco }\end{array}$ & $\begin{array}{c}\text { Sedimentos em forma de colina } \\
\text { ou elevações de areias trabalhadas } \\
\text { pela ação do vento }\end{array}$ & & Areias quartzosas & $<0,5 \%$ \\
\hline 9 & Serras e serrotes & $\begin{array}{c}\text { Elevações em forma de serra e } \\
\text { serrotes comumente apresentando } \\
\text { e expondo afloramentos de rocha }\end{array}$ & Ondulado & Litólicos & $1 \%$ \\
\hline 10 & $\begin{array}{c}\text { Superfícies arenosas do } \\
\text { São Francisco }\end{array}$ & $\begin{array}{l}\text { Depósito de material arenoso que } \\
\text { preenche uma grande fossa. } \\
\text { Superfície aplainada em forma de } \\
\text { chapadas com vales abertos }\end{array}$ & $\begin{array}{l}\text { Plano a suave } \\
\text { ondulado }\end{array}$ & Areias quartzosas & $3 \%$ \\
\hline
\end{tabular}


É comumente observada no relevo de Petrolina-PE a presença de vales escavados por rios intermitentes. Resumidamente, pode-se caracterizar o relevo do município como suave ondulado com a presença de inselbergs que se destacam no relevo.

\subsection{Clima}

O município de Petrolina apresenta clima tropical semiárido, caracterizado por altas temperaturas e irregularidade de chuvas. O fenômeno da seca, que acomete o nordeste brasileiro a anos, é caracterizado não pela falta absoluta de água, mas sim pela má distribuição das chuvas no tempo e no espaço. O semiárido nordestino é a única região semiárida do planeta localizada na zona equatorial da terra (entre os paralelos $11^{\circ} 43^{\prime} 19^{\prime \prime}$ de latitude norte e sul), o que o torna uma anomalia do ponto de vista da climatologia (BOTELHO, 2000).

A precipitação é o elemento meteorológico de maior variabilidade espacial e temporal, o que contribui para a escassez de recursos hídricos na região (EMBRAPA, 2001). O município permanece de 7 a 8 meses do ano sem chuvas, que se concentram de novembro a abril (Tabela 2.3) (INMET, 2016). Sendo que o mês de março é o mais chuvoso (com totais médios de chuva de 136,2 mm) e agosto o menos chuvoso do município (com totais médios de chuva de 4,8 mm). A umidade relativa do ar acompanha o regime de chuvas da região. Sendo que os meses mais úmidos do ano ocorrem de novembro a abril. Abril (umidade varia de 66 a 71,5\%), que corresponde ao fim do período chuvoso, e é o mês mais úmido. O período mais seco do ano acontece de setembro a outubro (umidade abaixo de 55\%) e o mês mais seco é outubro, que corresponde ao fim do período seco (EMBRAPA, 2001).

Tabela 2.3 - Precipitação acumulada por trimestre do município de Petrolina-PE

(Adaptado de INMET, 2016).

\begin{tabular}{|c|c|c|c|c|c|c|c|c|c|c|c|c|}
\hline TRIMIESTRE & $\begin{array}{c}\text { JAN } \\
\text { FEV } \\
\text { MAR }\end{array}$ & $\begin{array}{c}\text { FEV } \\
\text { ABR }\end{array}$ & $\begin{array}{c}\text { MAR } \\
\text { ABR } \\
\text { MAI }\end{array}$ & $\begin{array}{c}\text { ABR } \\
\text { MAI }\end{array}$ & $\begin{array}{c}\text { MAI } \\
\text { JUN } \\
\text { JUL }\end{array}$ & $\begin{array}{c}\text { JUN } \\
\text { JGO }\end{array}$ & $\begin{array}{c}\text { JUL } \\
\text { AGO } \\
\text { SET }\end{array}$ & $\begin{array}{c}\text { AGO } \\
\text { SET }\end{array}$ & $\begin{array}{c}\text { SET } \\
\text { OUT }\end{array}$ & $\begin{array}{c}\text { OUT } \\
\text { NOV }\end{array}$ & $\begin{array}{c}\text { NOV } \\
\text { DEZ }\end{array}$ & $\begin{array}{c}\text { DEZ } \\
\text { JAN }\end{array}$ \\
\hline $\begin{array}{c}\text { Limite Superior } \\
\text { da Faixa Normal }\end{array}$ & 317,2 & 290,5 & 223,8 & 94,1 & 39,3 & 13,7 & 10,7 & 14,8 & 71,1 & 150,3 & 231,6 & 283,3 \\
\hline Média & 285,1 & 259,2 & 188,5 & 82,6 & 28 & 14,4 & 9,3 & 17,1 & 63,1 & 129,6 & 201,7 & 240,4 \\
\hline $\begin{array}{c}\text { Limite Inferior } \\
\text { da Faixa Normal }\end{array}$ & 231,1 & 208,3 & 120 & 46,7 & 6,4 & 6,1 & 3,2 & 3,7 & 40 & 76,6 & 150 & 165,5 \\
\hline
\end{tabular}

As temperaturas são elevadas durante todo o ano com média de $26^{\circ} \mathrm{C}$ (SILVA \& OLIVEIRA, 2012). Dados históricos de estações meteorológicas localizadas em Petrolina e Juazeiro mostram que o mês de julho é o mais frio do ano e novembro é o mais quente.

Devido a tais características a evapotranspiração é elevada durante todo o ano. Os valores oscilam de $1.200 \mathrm{~mm}$ a $1.500 \mathrm{~mm}$ anuais. Em Silva \& Oliveira (2012), é apresentado o comportamento do total anual de evapotranspiração potencial calculada pelo método de Thornthwaite \& Mather de 1957 para o estado de Pernambuco. O resultado expressa a quantidade potencial de energia do ambiente (Figura 2.4) (SILVA \& OLIVEIRA, 2012). É possível observar que os maiores valores são encontrados próximo ao litoral e no limite sudoeste do estado, onde se localiza o município de Petrolina. 

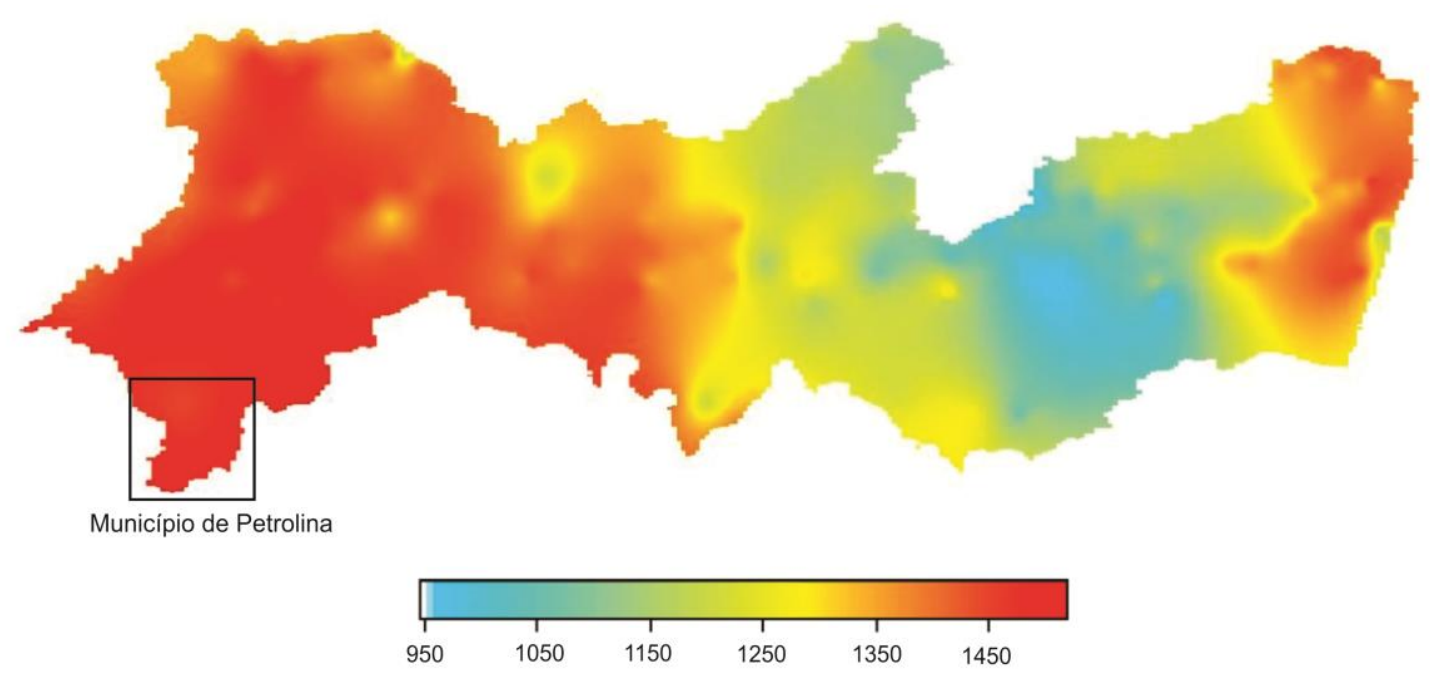

Figura 2.4 - Evapotranspiração do estado de Pernambuco em mm (Adaptado de SILVA \& OLIVEIRA, 2012).

Os valores de evapotranspiração acompanham as variações de temperatura ao longo do ano, sendo que os mais elevados são registrados de setembro a outubro (valores acima de 9 $\mathrm{mm} /$ dia) e os menos de março a julho (varia em média de 5,9 a 6,5 mm/dia) (EMBRAPA, 2001).

Segundo Botelho (2000), 92\% das precipitações no semiárido nordestino retornam para a atmosfera pela evapotranspiração, sendo que somente $8 \%$ escoem para os rios ou infiltram para os aquíferos (BOTELHO, 2000).

A EMBRAPA realizou o balanço hídrico climático com base em dados de estações meteorológicas localizadas em Petrolina e Juazeiro. O cálculo é feito com base nos ganhos e perdas de água na atmosfera. Os ganhos correspondem à precipitação pluvial e as perdas correspondem a evapotranspiração. Ocorre deficiência hídrica durante todo o ano com exceção no mês de março (EMBRAPA, 2001).

\subsection{Vegetação}

A vegetação do município de Petrolina é a caatinga, típica do sertão brasileiro.

Segundo o Ministério do Meio Ambiente a caatinga é rica em biodiversidade e abriga 178 espécies de mamíferos, 591 de aves, 177 de répteis, 79 de anfíbios e 241 de peixes. Possui imenso potencial para a conservação de serviços ambientais, uso sustentável e bioprospecção. Esta ampara diversas atividades econômicas e se bem explorada pode contribuir para o desenvolvimento da região semiárida e do país. Apesar de sua importância estima-se que $46 \%$ da área do bioma no Brasil estejam desmatadas (MMA, 2016).

\subsection{Geologia}

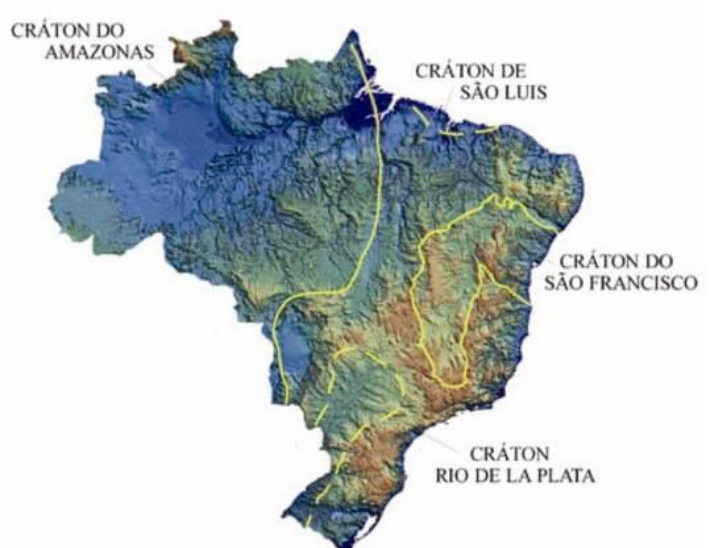

O município de Petrolina está localizado na transição entre o Cráton São Francisco e a Província Borborema. A parte sul de seu território expõe rochas do referido cráton e a porção norte já apresenta exposições da Província Borborema representada na área pela Faixa Móvel Riacho do Pontal.

A área do Cráton São Francisco corresponde do ponto de vista geográfico político aos estados de 
Minas Gerais, Bahia e Goiás (Figura 2.5), e, geologicamente, é limitado pelas faixas: Rio Preto, Riacho do Pontal, Sergipana, Araçuaí e Brasília. Resumidamente, o Cráton é formado por um embasamento Arqueano a Paleoproterozoico, que está encoberto por rochas sedimentares de idades do mesoproterozoico ao fanerozoico. Grande parte do embasamento esta coberto por sedimentos mais recentes, sendo que o mesmo, somente está exposto nos extremos sul e nordeste do cráton. $\mathrm{Na}$ exposição ao sul, o embasamento é representado pelas rochas do Cinturão Mineiro e na exposição nordeste pelas rochas dos Blocos Gavião, Jequié e Serrinha e do Cinturão Itabuna-Salvador-Curaçá. A cobertura sedimentar compreende 3 grandes unidades morfotectônicas, são elas: a Bacia do São Francisco, o Aulacógeno do Paramirim e uma grande parte do Rifte Recôncavo-Tucano-Jatobá. Além disso, também existem as bacias neoproterozoicas de antepaís do Rio Pardo e da Faixa Sergipana. As Bacias do São Francisco e o Aulacógeno do Paramirim são preenchidos em grande parte pelos Supergrupos Espinhaço (Paleo/Mesoproterozoico) e São Francisco (Neoproterozoico). O Cráton São Francisco foi consolidado ao final da orogênese Transamazônica e poupado pela orogênese Brasiliana, na qual estabeleceu seus limites atuais (Figura 2.6) (ALKMIM, 2004). O município de Petrolina está aproximadamente localizado no quadrado verde em destaque na Figura. O mesmo se encontra próximo ao limite norte do Cráton São Francisco, onde ocorrem porções do embasamento, representado pelo Bloco Gavião, e o Aulacógeno do Paramirim.

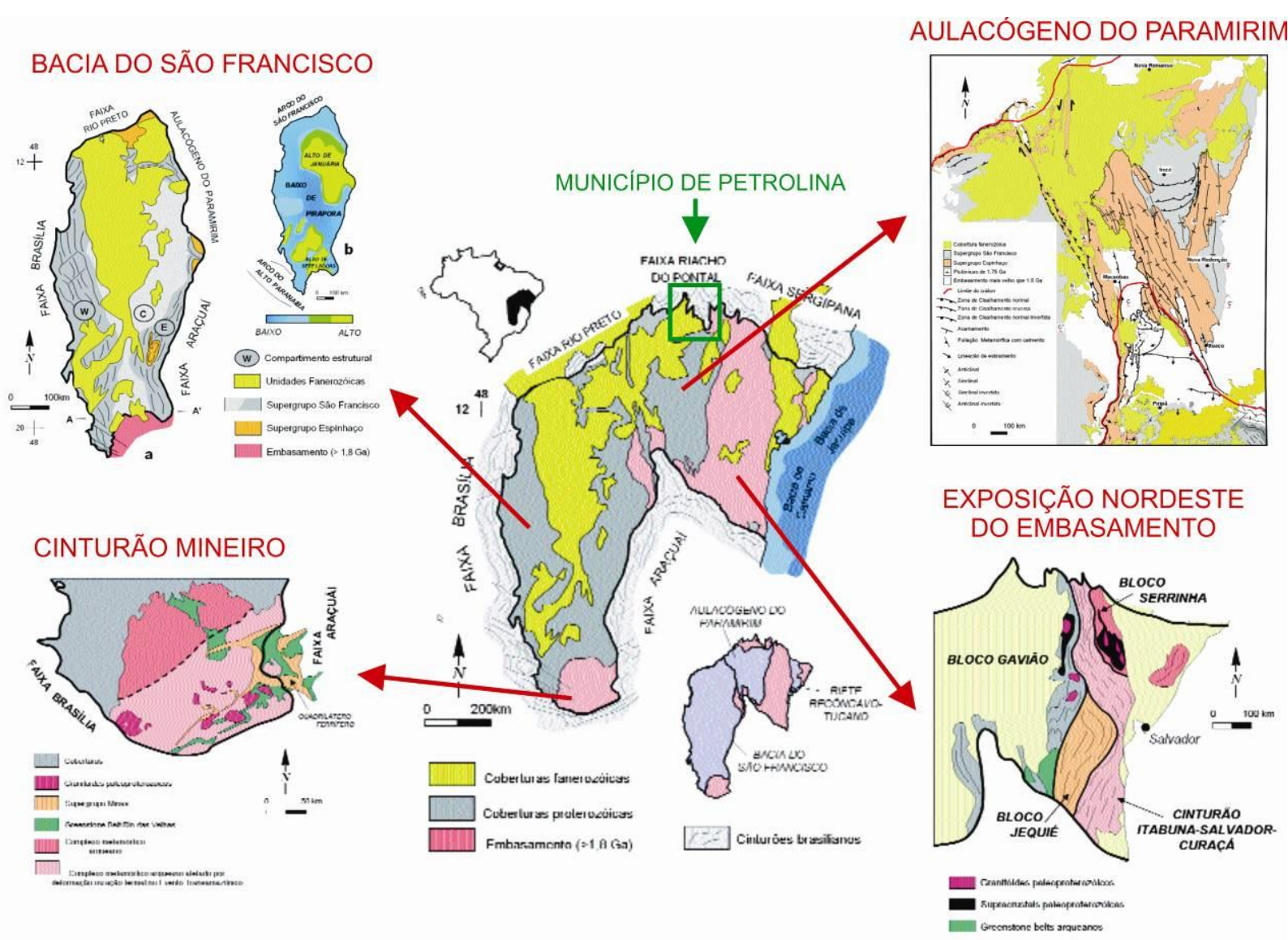

Figura 2.6 - Geologia regional do Cráton São Francisco. Ao norte em verde a localização aproximada do município de Petrolina-PE (Modificado de ALKMIM, 2004).

As faixas móveis Rio Preto, Riacho do Pontal e Sergipana representam um sistema orogênico de mais de $1.000 \mathrm{Km}$ de extensão desenvolvido diacronicamente na margem norte do Cráton São Francisco durante o Neoproterozoico (UHLEIN et al., 2011). O município de 
Petrolina se localiza no limite do Cráton São Francisco com a Faixa Riacho do Pontal de forma que elementos de ambos estão aflorando em sua área.

A Faixa Móvel Riacho do Pontal ocorre a norte do Cráton São Francisco, e pertence à Província Borborema. A Província Borborema, ou Sistema Orogênico Borborema, abrange grande parte do nordeste brasileiro e é definida por HASUI (2012) como um mosaico de porções de embasamento, micros continentes e faixas orogênicas do arqueano ao neoproterozoico separadas por zonas de cisalhamento transcorrentes e de empurrão. A Província é dividida pelo mesmo autor em compartimentos distintos que são separados de maneira regional pelas zonas de cisalhamento Patos e Pernambuco (Figura 2.7). O autor ressalta que tal compartimentação não tem significado geotectônico ou evolutivo, mas simplesmente geométrico (HASUI, 2012).

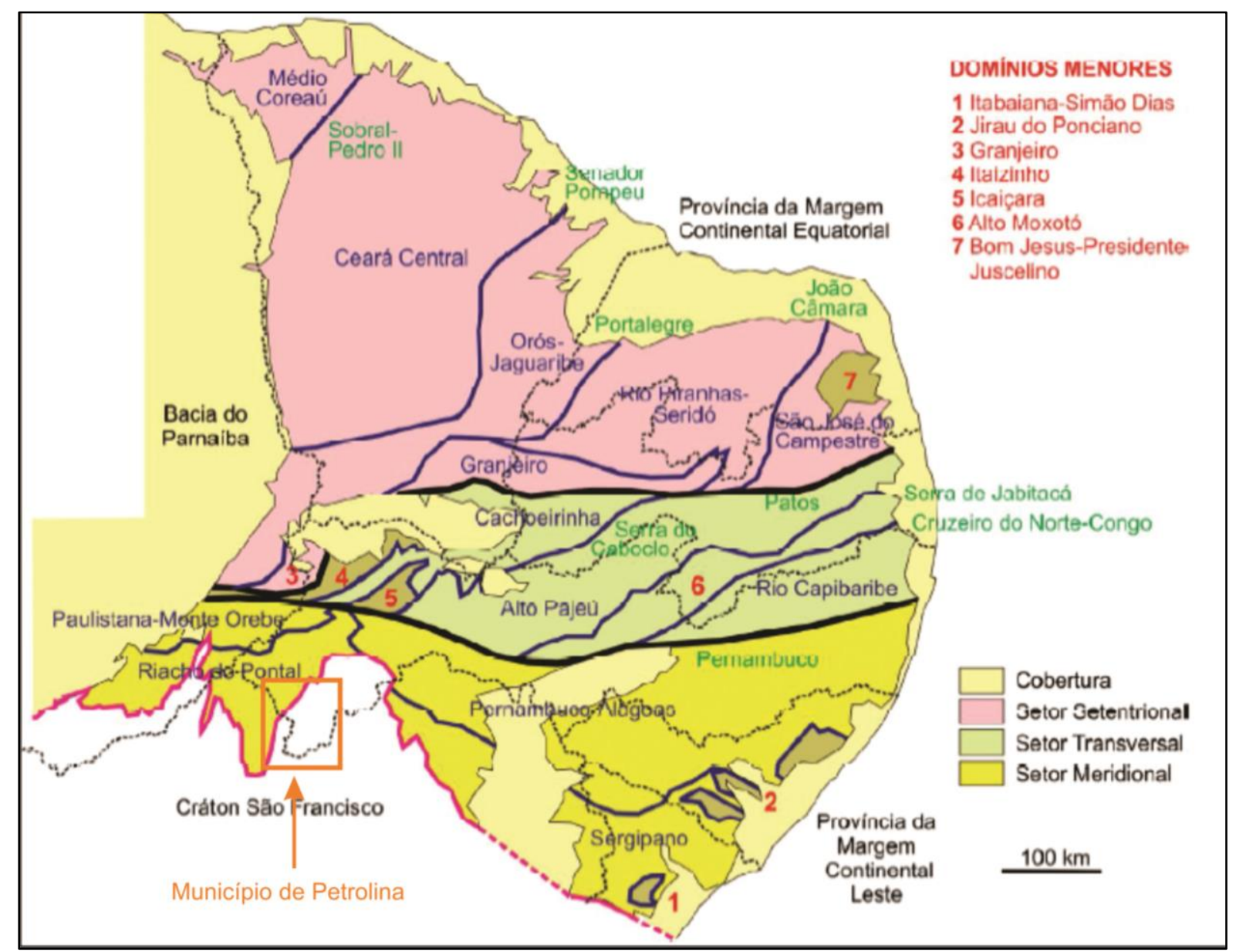

Figura 2.7 - Visão regional da Província Borborema com a compartimentação feita por HASUI (2012). Em preto estão as zonas de cisalhamento Pernambuco e Patos que separam a Província em 3 setores e as linhas azuis representam as zonas de cisalhamento que separam os setores em domínios. Os nomes dos domínios estão em azul e vermelho. E o nome das zonas de cisalhamento em verde. $O$ quadrado laranja representa a localização aproximada do município de Petrolina (Adaptado de HASUI, 2012).

A porção norte do município de Petrolina encontra-se no Setor Meridional, domínio Riacho do Pontal. A separação do domínio Riacho do Pontal e do domínio Paulistana-Monte Orebe, ainda é duvidosa sendo que novos estudos devem ser feitos na região para que a questão seja resolvida (em outros trabalhos os 2 domínios são indicados como Faixa Móvel Riacho do Pontal). Os domínios Riacho do Pontal e Paulistana-Monte Orebe possuem rochas datadas do paleoproterozoico ao neoproterozoico. O contato do domínio Riacho do Pontal com o Cráton São Francisco é por uma zona de cisalhamento de empurrão com vergência para sul (HASUI, 2012). 
Segundo os mesmos autores ocorrem na porção do município de Petrolina correspondente ao Domínio Riacho do Pontal rochas pertencentes: ao Grupo Casa Nova, a Suíte Granitóides Sintectônicos Rajada (670 Ma) e outras, do Neoproterozóico; e a Granitos da região de Casa Nova a oeste do município, do Paleoproterozóico (HASUI, 2012).

Uhlein et al. (2004), são exemplos de pesquisadores que denominam de Faixa Móvel Riacho do Pontal a junção dos domínios Riacho do Pontal e Paulistana-Monte Orebe. A Faixa Móvel Riacho do Pontal, foi formada durante a orogenia brasiliana, no Neoproterozoico. Ela correspondia a uma bacia sedimentar de margem passiva desenvolvida na borda do paleocontinente São Francisco que sofreu processos de inversão tectônica no Neoproterozoico. Apresenta estruturação de dobras e empurrões com vergência para a área do cráton, sul. Envolve um embasamento Arqueano/Paleoproterozoico remobilizado e várias unidades estratigráficas Meso a Neoproterozoicas com metamorfismo em fácies xisto verde e anfibolito (UHLEIN et al., 2004; UHLEIN et al., 2011).

A Faixa Riacho do Pontal é composta de um embasamento gnáissico-migmatítico Arqueano a Paleoproterozoico, rochas metassedimentares de ambiente deposicional marinho raso a profundo, metavulcânicas e metaplutônicas máficas e ultramáficas relacionadas ao Grupo Casa Nova e diferentes gerações de intrusões graníticas (UHLEIN et al., 2011).

Uhlein et al. (2011) cita a ocorrência de rochas do embasamento da Faixa Móvel Riacho do Pontal que correspondem ao Cráton São Francisco no chamado Bloco Gavião no sul do município de Petrolina. Em tal embasamento ocorrem ortognaisses do tipo TTG, em grande parte migmatizados, com bandas tonalíticas/granodioríticas e corpos leucograníticos. É datado do arqueano ao paleoproterozoico. Já na porção norte do município o autor relata exposições do Grupo Casa Nova (sequência metavulcanossedimentar), Suíte Serra da Esperança (sienitos sin a tardi-colisionais) e Suíte Rajada (ortognaisses a duas micas sin colisionais) (Figura 2.8). Ambos pertencentes a Faixa Móvel em questão.

O Grupo Casa Nova é subdividido em 3 formações que se interdigitam lateral e verticalmente de sul para norte, são elas: Formação Barra Bonita, Formação Mandacaru e Formação Paulistana-Monte Orebe. A Formação Paulistana-Monte Orebe é uma unidade vulcano sedimentar constituída por: metavulcânicas, metapelitos, metachert, quartzitos e quartzo-xistos de idade de sedimentação em torno de 740 Ma. Já a Formação Barra Bonita apresenta biotita xistos, mármores e quartzitos e representa uma sedimentação marinha plataformal. Por fim, a Formação Mandacaru é constituída por mica xistos com interdigitações centimétricas e dessimétricas de metagrauvacas (UHLEIN et al., 2011).

A Suíte Rajada é composta por sills sincolisionais de ortognaisses de composição tonalítica, granodiorítica e sienograníticas a duas micas datadas de aproximadamente 668 Ma. Já a Suíte Serra da Esperança é composta por granitoides sin- a tardi-colisionais, sienitos, e quartzo sienitos datados de cerca de 560 Ma (UHLEIN et al., 2011) (Figura 2.9). 


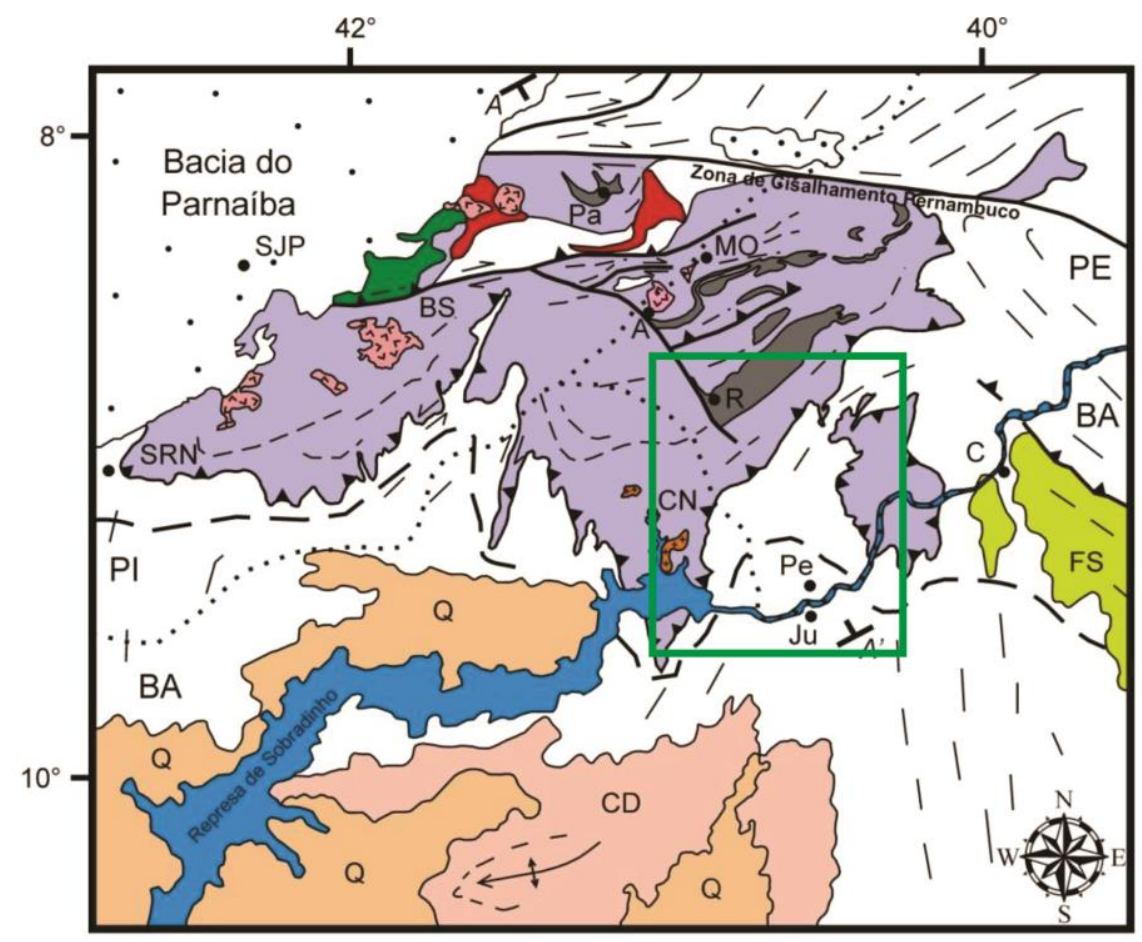

Cobertura Quaternária - Q

$\because$ Sedimentos

Paleo-Mesozóicos

Neoproterozóico

Suite Serra da Aldeia / Caboclo

Sienito e K-feldspato granito

Tardi a pós-colisional

Suite Serra da Esperança

Sienito sin a tardi-colisional

$555 \pm 10 \mathrm{Ma}, \mathrm{Rb}-\mathrm{Sr}$ rocha total (1)

\section{Suite Rajada}

Ortognaisse a duas micas, sin-colisional

$668 \pm 10 \mathrm{Ma}$, isócrona composta $\mathrm{Rb}-\mathrm{Sr}$ (2)

Complexo Brejo Seco

Metamáficas / ultramáficas

\section{Grupo Casa Nova}

Sequência metavulcanosedimentar

Supracrustais da

Faixa Sergipana - FS

ESCALA

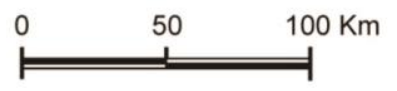

1/ Traço da foliação

$\lceil$ Zona de cisalhamento

de empurrão

1. Zona de cisalhamento transcorrente

LOCALIDADES

C - Curaçá

$\mathrm{CN}$ - Casa Nova

Ju - Juazeiro

$\mathrm{Pe}$ - Petrolina

R - Rajada

A - Afrânio

MO - Monte Orebe

$\mathrm{Pa}$ - Paulistana

BS - Brejo Seco

SJP - São Joăo do Piauí

$\therefore \quad$ Divisa BA-PE-PI

SRN - São Raimundo Nonato

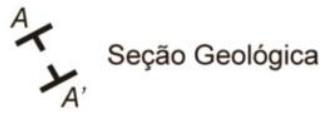

\section{Mesoproterozóico}

Rochas metassedimentares

Chapada Diamantina - CD

\section{Suíte Afeição}

Ortognaisse, $966 \pm 10 \mathrm{Ma}, \mathrm{U}-\mathrm{Pb}$ TIMS (3)

Embasamento

Arqueano/Paleoproterozóico

(1) - Jardim de Sá et al. (1996); (2) - Jardim de Sá et al. (1992);

(3) - Van Schmus et al. (1995)

Figura 2.8 - Mapa geológico simplificado da Faixa Riacho do Pontal. O quadrado verde mostra a localização aproximada do município de Petrolina-PE (Adaptado de UHLEIN et al, 2011). 

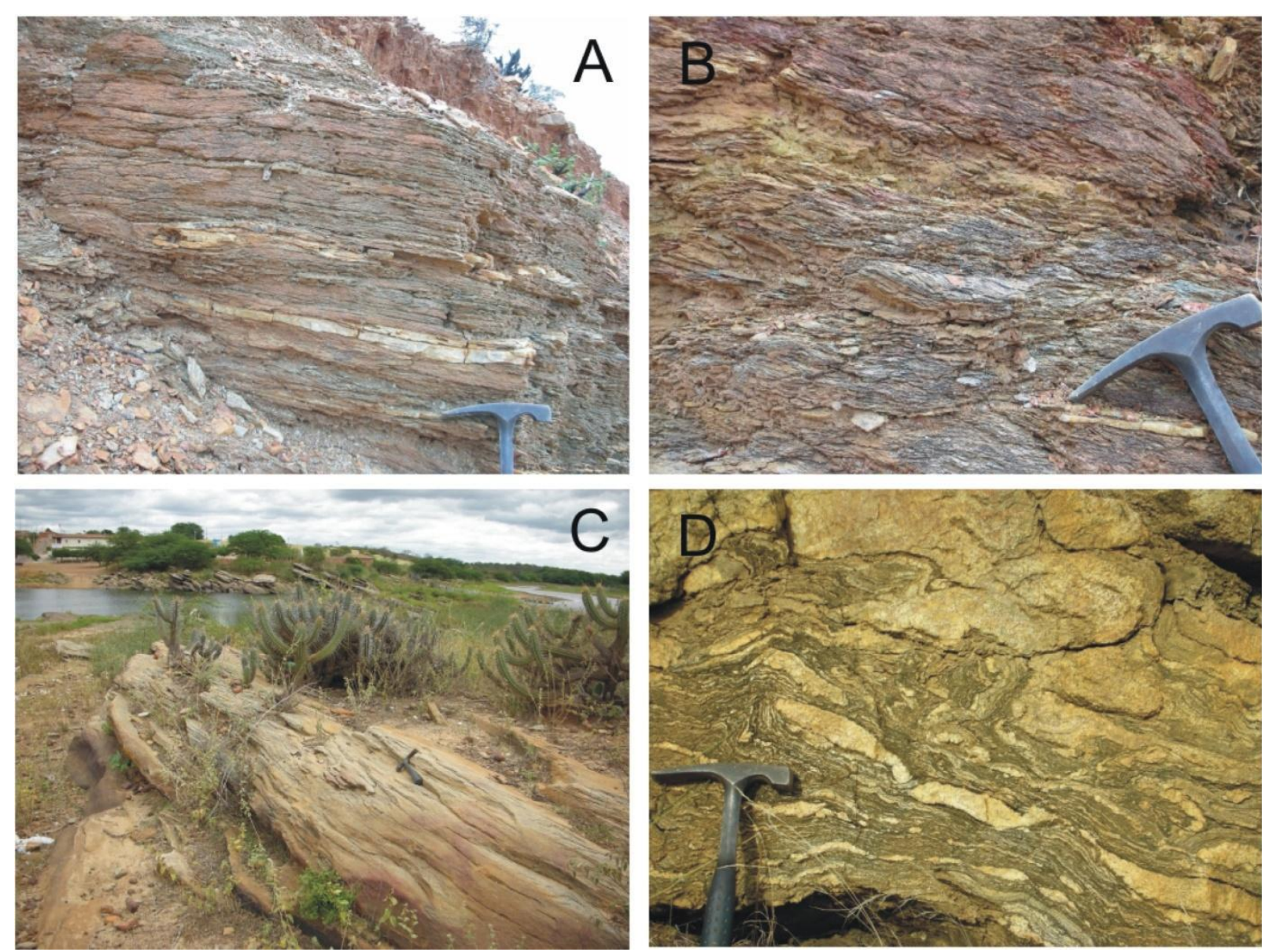

Figura 2.9 - Litotipos da Faixa Riacho do Pontal. A - Metagrauvaca e metapelito da Formação Mandacaru; B - Mica xisto da Formação Barra Bonita, com estrutura S/C, devido à deformação tangencial (D1), próximo ao contato com o embasamento, no povoado de Pau Ferro, ao sul de Rajada. C - Suíte Rajada: granitoide foliado, sintectônico, na barragem do açude de Rajada. D - Gnaisse bandado, pertencente ao Embasamento, que aflora como escama tectônica na região de Afrânio (Complexo Morro do Estreito) (UHLEIN et al, 2011).

Segundo Beltrão et al. (2005), as unidades presentes no município de Petrolina são: Complexo Gnaíssico-migmatítico Sobradinho/Remanso, Greenstone Belt Rio Salitre e Complexo Saúde, pertencentes ao Bloco Gavião do Cráton São Francisco; Granitoides Sin e Póstectônicos, Grupo Casa Nova (Formação Mandacaru) e Suíte Intrusiva Metaluminosa e Peraluminosa Rajada, pertencentes a Faixa Móvel Riacho do Pontal; e Depósitos Detrítico e/ou Laterítico, Depósitos Colúvio-eluviais, Paleodunas Continentais e Depósitos Aluvionares recentes. As rochas do embasamento cristalino são datadas do Paleoarqueano ao Neoproterozoico. Seguido de depósitos recentes do Cenozoico. Próximo ao Rio São Francisco são observados sedimentos de depósitos aluvionares e paleodunas (Figura 2.10).

Em CPRM (2014b), o mapeamento da porção sul do município sofreu atualizações sendo que o Complexo Gnáissico-migmatítico Sobradinho/Remanso (Paleoarqueano/Mesoarqueano) foi restringido a pequenas áreas isoladas no município e a grande exposição de rochas antes atribuída a tal unidade foi classificada como Suíte Juazeiro que se refere a granitoides Neoarqueanos da região de Lagoa do Alegre/Rio Salitre. 


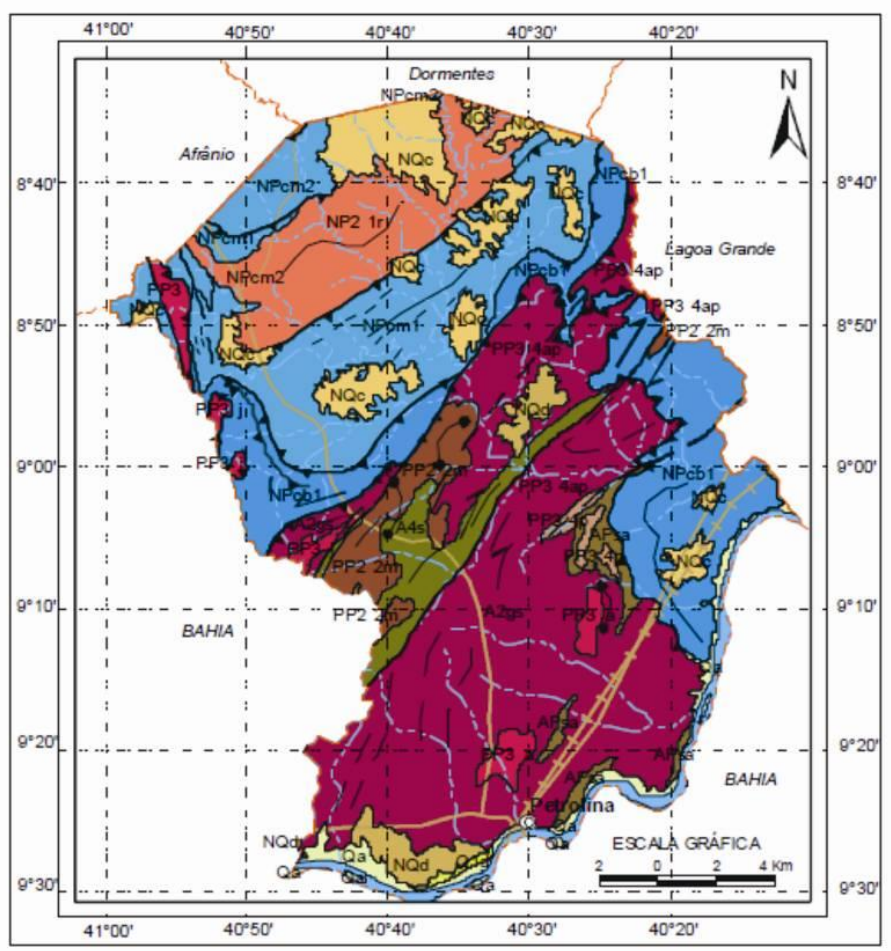

\section{UNIDADES LITOESTRATIGRAFICAS}

Cenozóico

Qa Depósitos Aluvionares: areia, cascalho e niveis de argila

Q1d Paleodunas Continentais: areia bem selecionada

\begin{tabular}{|l|l}
\hline NQc Depósitos Colúvio-eluviais: sedimento arenoso, areno-argiloso \\
\hline
\end{tabular}

NQd Depósitos Detríticos e/ou Lateriticos: sedimento arenoso,

Neoproterozóico

ortognaisse a duas micas tonalitico a sienogranitico

NPam2 Grupo Casa Nova - Formação Barra Bonita (cb1): xisto e mármore

NPom1 Grupo Casa Nova - Formação Mandacaru (cm1): xisto e metagrauvaca

NPcb1 Grupo Casa Nova - Formaçăo Mandacaru (cm2): metagrauvaca Paleoproterozóico

PP3 4ap Granitóides Pós-tectônicos: leucogranito a granito a duas micas,

PP3 aj Granitóides Pós-tectônicos: granito alcalino

PP2 2m Granitóides Sintectônicos: granito, granodiorito, monzogranito gnaissificados Arqueano a Paleoproterozóico

APsa Complexo Saúde: paragnaisse, paragnaisse aluminoso migmattitico, quartzito

Arqueano

A4s Greenstone Belt Rio Salitre: metavulcânica máfica, ultramáfica e félsica,

Paleoarqueano

A2gs Complexo Gnáissico-migmatititco Sobradinho/Remanso: ortognaisse tonalitico-
CONVENÇÕES GEOLOGICAS

Contato Geológico

- Dique

- Falha ou Fratura, tracejada quando encoberta

_._. Falha ou Zona de Cisalhamento Contracional

$\longrightarrow$ Falha ou Zona de Cisalhamento Transcorrente Dextral

$\leftrightharpoons$ Falha ou Zona de Cisalhamento Transcorrente Sinistral

- - Falha ou Zona de Cisalhamento,

Traceja

1. Testemunho Estrutural

\section{CONVENÇÕES CARTOGRÁFICAS}

- Cidade

Limite municipal

+1 Estrada de forro

_ Estrada não pavimentada

Estrada pavimentad

Rio intermitente

Rio São Francisco

Figura 2.10 - Mapa geológico do município de Petrolina-PE segundo Beltrão et al. (2005). 
Do ponto de vista estrutural, a área apresenta falhas, fraturas, zonas de cisalhamento contracionais e transcorrentes e diques. As principais falhas/zonas de cisalhamento contracionais separam blocos distintos. O bloco mais antigo, soerguido por tais falhas, é representado predominantemente por rochas do Completo Gnáissico-migmatítico Sobradinho/Remanso e é datado do Paleoarqueano ao Paleoproterozoico. Já o bloco mais novo é representado por rochas da Formação Mandacaru, Grupo Casa Nova e Suíte Intrusiva Metaluminosa a Peraluminosa Rajada, ambas datadas do Neoproterozoico. Na porção norte do município as falhas/zonas de cisalhamento contracionais tem direção preferencial NE-SW. Na porção leste da área do município ocorrem falhas/zonas de cisalhamento transcorrentes dextrais. As falhas e fraturas encobertas possuem direção preferencial NE-SW e N-S (BELTRÃO et al., 2005).

$\mathrm{O}$ arcabouço estrutural na porção norte do Aulacógeno do Paramirim, que corresponde à porção sul do município, é descrito por Alkmim (2004). O mesmo explana que as estruturas dominantes são parcialmente obliteradas por um sistema de falhas de empurrão de orientação preferencial EW e vergência para sul. Esse sistema avança de forma epidérmica em direção ao sul até quase a metade da área do Aulacógeno.

Uhlein et al. (2011) descreve a geologia estrutural da Faixa Riacho do Pontal. A mesma apresenta deformação complexa com o desenvolvimento de nappes em sua porção externa e transcorrências em sua porção interna. Sua evolução estrutural pode ser dividida em 2 fases sendo D1 de tectônica tangencial e D2 de tectônica transcorrente. A fase D1 originou nas rochas do Grupo Casa Nova, uma xistosidade milonítica proeminente (S1) e uma lineação de estiramento orientada 320 a 350 de azimute. O transporte tectônico nessa fase é para sul-sudeste em direção ao Cráton São Francisco evidenciado por dobras assimétricas apertadas a isoclinais, dobras em bainha e estruturas SC. A idade aproximada para a fase D1 é 555 Ma e o metamorfismo varia de fácies xisto verde ao sul até anfibolito ao norte o que é coerente com empilhamento de nappes de norte para sul. A fase D2, por sua vez, possui tectônica transcorrente e gerou feições importantes como a Zona de Cisalhamento Pernambuco. Além dela também foram geradas foliação milonítica subvertical e lineação de estiramento sub-horizontal além de zonas de cisalhamento transcorrentes subordinadas (UHLEIN et al., 2011).

O município de Petrolina se localiza na zona externa da Faixa Riacho do Pontal onde se destaca um fold-and-thrust belt com predomínio de rampas frontais de baixo ângulo, nappes e rampas laterais envolvendo as Formações Barra Bonita e Mandacaru. A leste de Petrolina podese encontrar a klippe de Barra Bonita, que é uma porção alóctone do Grupo Casa Nova (Figura 2.11) (UHLEIN et al., 2011).

Durante os trabalhos de campo realizados no Projeto RECARFRAT foram medidas fraturas em uma pedreira abandonada localizada as margens da BR-407 próximo à sede do município de Petrolina. Com os referidos dados, rosetas de $360^{\circ}$ e $180^{\circ}$ foram elaboradas (Figura 2.12). Nestas rosetas é possível observar a presença de fraturas na direção NE-SW, como representado no mapa de Beltrão et al. (2005), porém a direção predominante é NW-SE. Presença de biotita foi observada nas fraturas NW-SE e NE-SW.

Os solos do município de Petrolina são em geral pouco evoluídos e espessos. Nas proximidades de rios intermitentes é observado pacote de aluvião mais espesso. Foi observada, em campo, a presença de uma camada de cascalho predominantemente quartzosa localizada entre o solo e as rochas. Tais blocos foram utilizados para preencher as trincheiras de recarga dos sistemas de recarga artificial. Em afloramentos localizados na pedreira abandonada, é evidente que os solos se tornam mais espessos sobre os planos e intersecções de fraturas. 


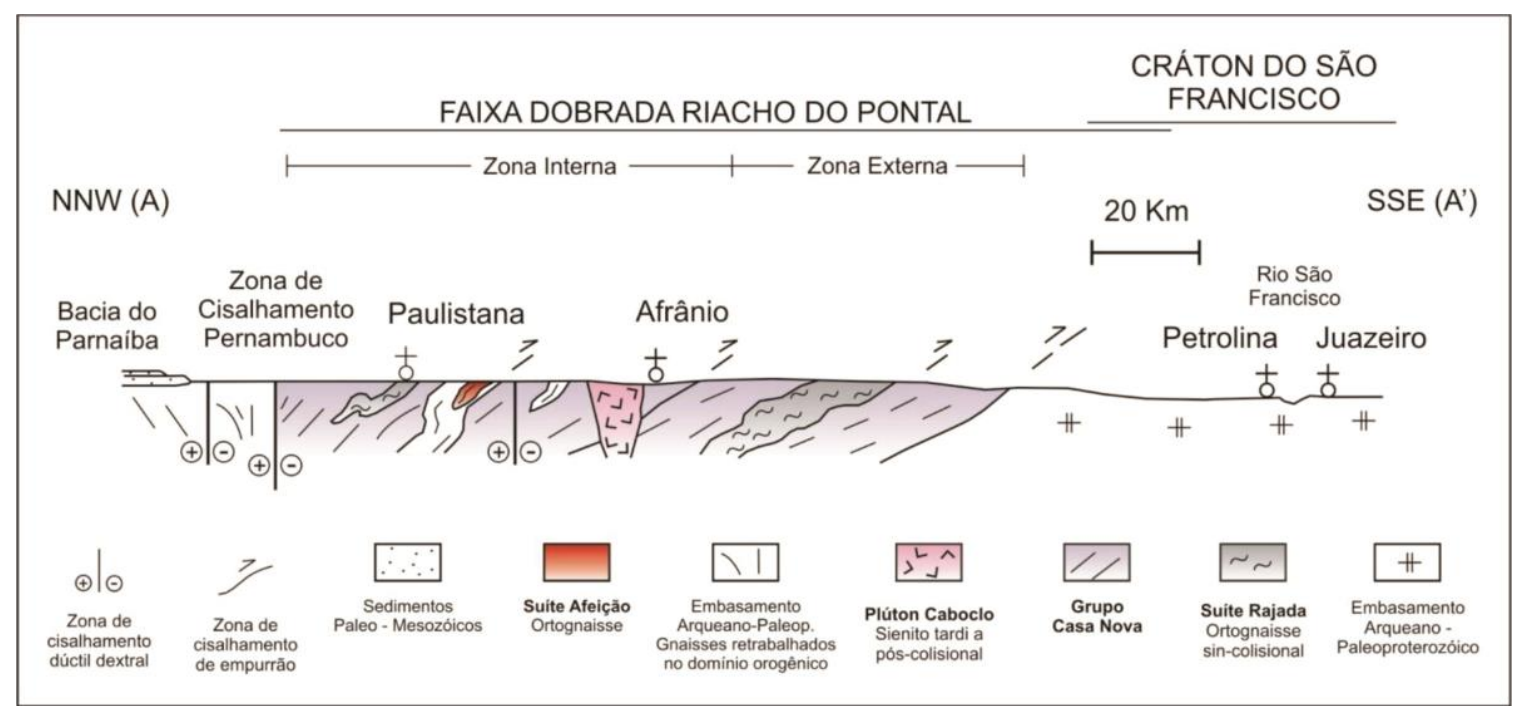

Figura 2.11 - Seção geológica simplificada da Faixa Riacho do Pontal e da porção norte do Cráton São Francisco com indicação das zonas interna e externa (UHLEIN et al., 2011).
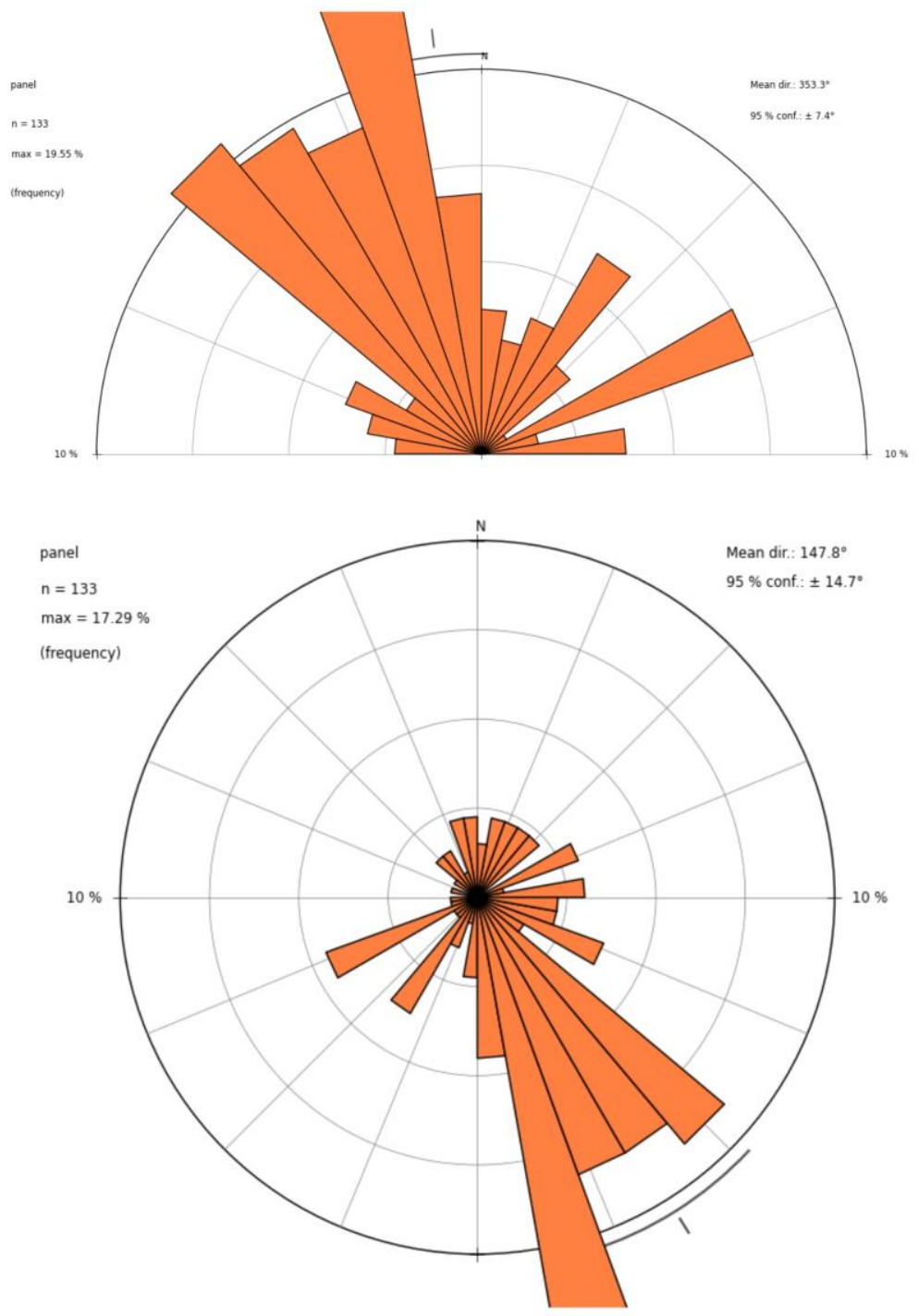

Figura 2.12 - Roseta de fraturas de pedreira localizada as margens da BR-407 no município de Petrolina-PE.

A Figura 2.13 apresenta imagens obtidas durante os trabalhos de campo do projeto RECARFRAT de afloramentos encontrados no município. 


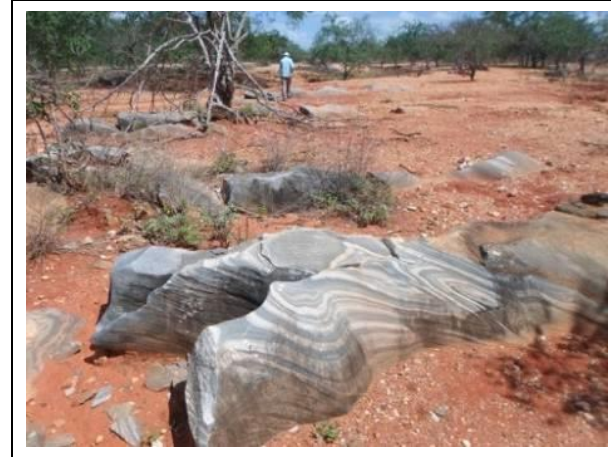

Afloramento de mármore bandado associado a solos avermelhados provavelmente pertencente a Formação Barra Bonita do Grupo Casa Nova.

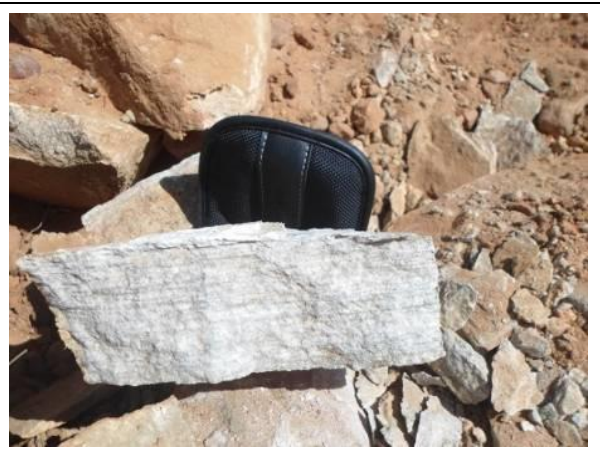

Detalhe para o gnaisse provavelmente pertencente ao Bloco Gavião do Cráton São Francisco.

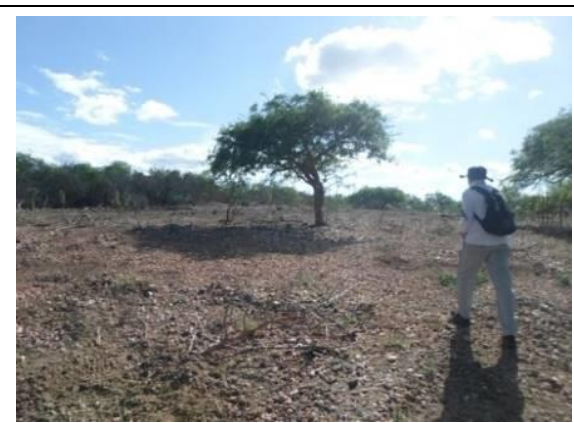

Camada de cascalho localizada entre o solo pouco espesso e as rochas observadas em campo. Foto retirada na Fazenda do Sr. Jair onde está localizado um sistema piloto da fazenda do Jair.

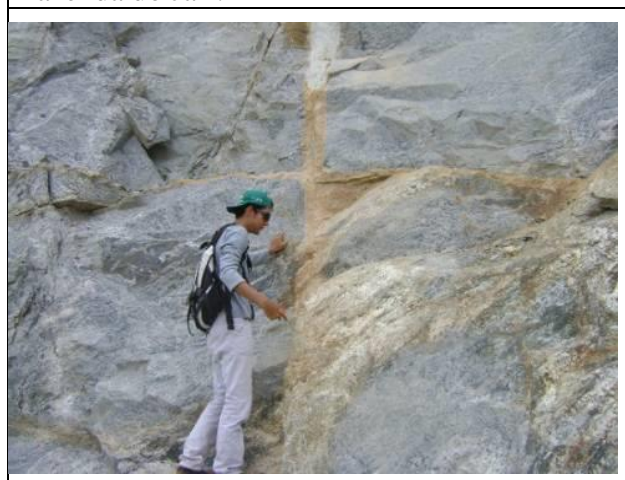

Detalhe para intercessão de fraturas na pedreira abandonada.

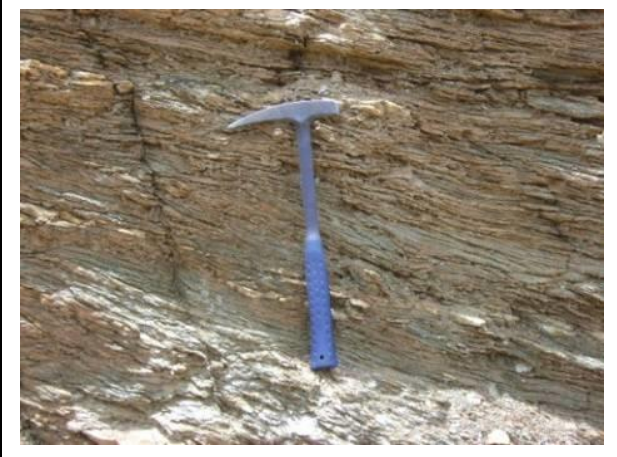

Afloramento de xisto provavelmente pertencente a Formação Mandacaru ou Barra Bonita do Grupo Casa Nova.

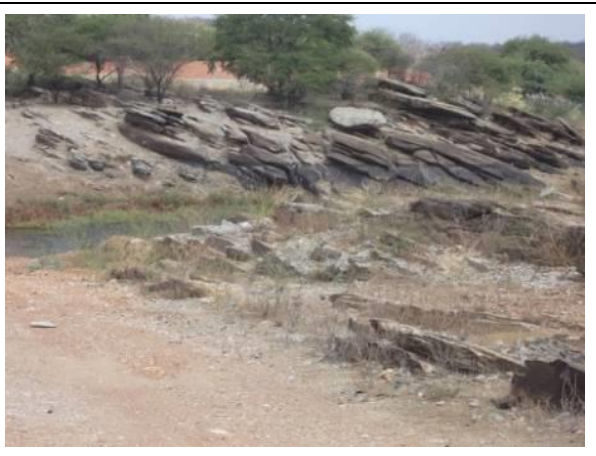

Gnaisses com foliação milonítica de baixo ângulo.

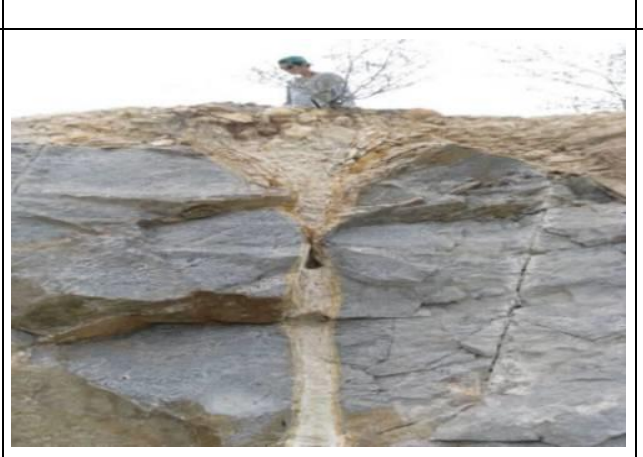

Detalhe para solo mais espesso associado à fratura aflorante. Foto retirada na pedreira abandonada localizada na BR-407.

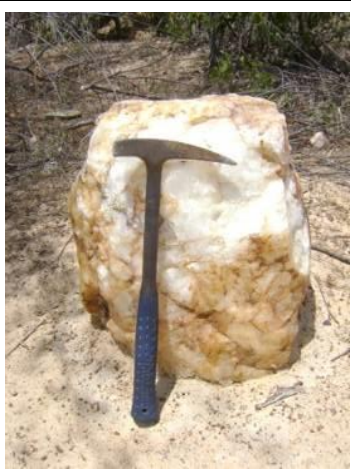

Detalhe para bloco de quartzo presente na camada de cascalho localizada entre o solo e a rocha.

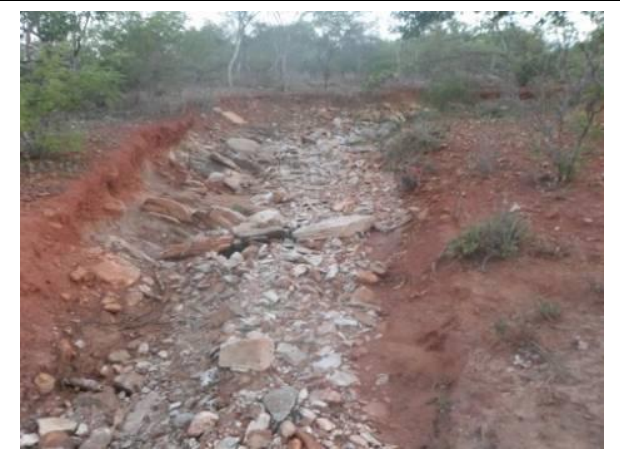

Afloramento de gnaisse próximo a poço tubular denominado na presente tese de 113 provavelmente pertencente ao Bloco Gavião do Cráton São Francisco.

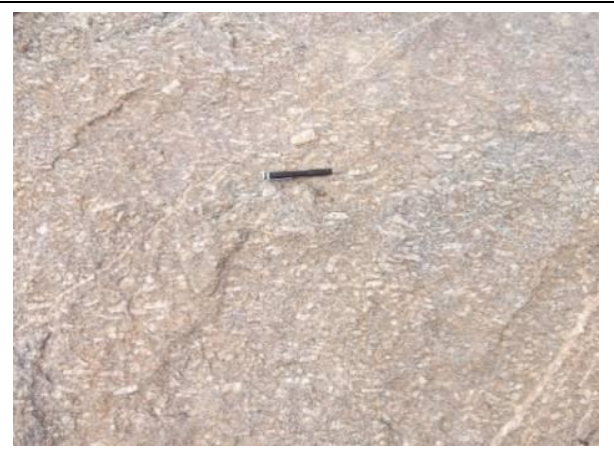

Afloramento de gnaisse com detalhe em porfiroclastos de feldspato potássico alinhados provavelmente pertencente ao Bloco Gavião do Cráton São Francisco.

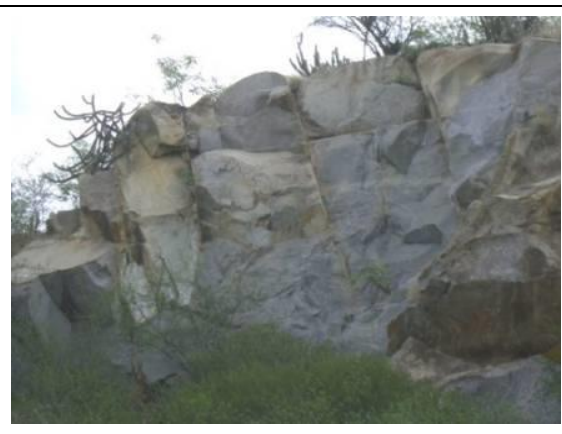

Paredão localizado na pedreira abandonado evidenciado a presença de fraturas subhorizontais que interligam as fraturas com mergulhos mais evidentes.

Afloramento de gnaisse bandado dobrado.

Figura 2.13 - Fotos dos afloramentos observados no município de Petrolina-PE durante os trabalhos de campo do Projeto RECARFRAT. 


\subsection{Hidrogeologia}

Como já explicitado anteriormente, o município de Petrolina está localizado sobre rochas do embasamento cristalino representantes do Cráton São Francisco (na porção sul do município) e da Faixa Móvel Riacho do Pontal (na porção norte). Na área as estruturas são predominantemente dúcteis o que é evidenciado pela grande quantidade de gnaisses observados. Os aquíferos ocorrem de 2 formas: nos sedimentos inconsolidados superficiais (solos e depósitos aluvionares) e nas estruturas rúpteis em fraturas presentes nas rochas.

Como os solos são pouco espessos, acumulações de água nas porções superficiais são muito restritas. As maiores acumulações de água estão nos sedimentos inconsolidados nas proximidades das drenagens (correspondentes aos depósitos aluvionares). As chuvas tendem a se acumular a princípio nessa porção, mas a elevada taxa de evapotranspiração faz com que grande parte das acumulações seja perdida. Nessas áreas são encontradas águas menos salinas, porém em quantidades limitadas.

Abaixo dos solos encontram-se os aquíferos fraturados. As fraturas no município de Petrolina são pouco interconectadas sendo que o fluxo nos aquíferos fraturados é restrito. Em campo foi possível observar que poços localizados relativamente próximos possuem características hidráulicas (vazão, nível estático) e características das águas (condutividades elétricas) bastante distintos; indicando que os aquíferos da área ocorrem em sistemas de fraturas isolados e que não existe um fluxo regional expressivo. Supõe-se que esses sistemas de fraturas sejam interligados por grandes fraturas sub horizontais que servem como grandes condutoras e armazenadoras de águas. O fluxo regional estaria ligado a essas grandes fraturas sub horizontais.

A explotação de água subterrânea no município ocorre predominantemente de 2 maneiras. Poços tubulares pouco profundos e com filtros próximos a superfície que são utilizados para retirada de água dos solos e sedimentos inconsolidados dos depósitos aluvionares. Já poços tubulares profundos são utilizados para captação de água dos aquíferos fraturados. Existe um perfil construtivo padrão utilizado em quase todos os poços tubulares profundos projetados para captação de água dos aquíferos fraturados. Nesse perfil, o revestimento é colocado somente na porção correspondente aos solos onde é feita a cimentação entre a parede do poço e o revestimento. Da profundidade onde acabam os solos até o final da perfuração, geralmente, não são colocados nem pré-filtros e nem filtros ou revestimentos. Para retirada da água são utilizadas predominantemente bombas movidas por cata-ventos. As bombas elétricas existem em poucas residências devido a problemas na rede elétrica do município principalmente na área rural.

Existe uma grande quantidade de poços secos em Petrolina o que reforça a dificuldade na locação de poços da área. As vazões observadas em campo nos poços produtores são entre 1.000 e $5.000 \mathrm{~L} / \mathrm{h}$. Quanto ao confinamento, a maior parte dos aquíferos encontra-se confinado por pacotes de rochas maciços ou com fraturas secas. Sendo assim, na perfuração de poços na região é comum que o nível estático seja mais raso que a profundidade de entrada de água. Entretanto, ocorrem também porções livres dos aquíferos nas áreas mais elevadas do relevo.

A recarga dos aquíferos fraturados se dá tanto por águas de chuva que infiltram nos solos e escorrem por fluxo lateral e no contato solo-rocha até encontrarem fraturas onde infiltram nos aquíferos fraturados. Quanto, nas porções livres e aflorantes dos aquíferos fraturados nas áreas elevadas do relevo. 
O fluxo restrito de água nos aquíferos fraturados faz com que as águas subterrâneas permaneçam longos períodos de tempo em contato com as rochas nas fraturas. Isso permite que o processo de interação água-rocha possa atuar por um tempo prolongado.

As condutividades elétricas das águas subterrâneas são variadas sendo que nos aquíferos presentes nos sedimentos inconsolidados dos depósitos aluvionares elas são menores $(<500$ $\mu \mathrm{S} / \mathrm{cm}$ ) e nos aquíferos fraturados encontram-se os maiores e mais preocupantes valores (a maioria $>1.000 \mu \mathrm{S} / \mathrm{cm})$.

\subsection{Aspectos Socioeconômicos}

O município de Petrolina possui uma população, estimada em 2015, de 331.951 habitantes, sendo sua densidade demográfica de $64,4 \mathrm{hab} / \mathrm{km}^{2}$. Nota-se, principalmente na área rural do município, uma grande quantidade de famílias sem condições básicas de higiene, saneamento básico e sem acesso a água de boa qualidade. As casas são simples e localizadas principalmente ao longo de leitos de rios que permanecem quase sempre secos. A escassez de água para consumo humano é evidente sendo que o abastecimento da área rural é feita principalmente por caminhões pipa. O Índice de Desenvolvimento Humano Municipal (IDHM) em 2010 era de 0,697, considerado médio pelo Atlas de Desenvolvimento Humano no Brasil. Segundo o mapa de pobreza e desigualdade dos municípios brasileiros, elaborado em 2003, estimou-se que a incidência de pobreza no município era de 42,96\% (IBGE, 2016).

Apesar da condição social delicada do município, principalmente na área rural, o mesmo possui importância regional do ponto de vista econômico. Sendo importante produtor agrícola e industrial do nordeste brasileiro devido as grandes áreas de projetos de irrigação.

O Produto Interno Bruto (PIB) do município, estimado em 2013, era de 4.905 .327 mil reais, sendo que a indústria, agricultura e serviços são os que contribuem de maneira mais efetiva para esse valor. Segundo o IBGE é o $22^{\circ}$ município que mais contribui pra o PIB da região nordeste (IBGE, 2015).

Petrolina, juntamente com Juazeiro, é um importante polo agroindustrial do nordeste brasileiro. Os municípios são importantes produtores de frutas e verduras para exportação o que contribui significativamente com a economia dos estados de Pernambuco e Bahia. O polo possui lavouras permanentes de: banana, goiaba, coco-da-baía, limão, mamão, manga, maracujá, uva, entre outros; bem como lavouras temporárias de: cana de açúcar, mandioca, cebola, entre outros.

Segundo o Censo Agropecuário do IBGE de 2006, o polo Juazeiro-Petrolina revelou-se uma das mais promissoras e extensas áreas de lavoura irrigada no nordeste brasileiro (IBGE, 2012). Petrolina é o maior município produtor de frutas do país cuja produção somou $R \$ 470,3$ milhões, o que representa 1,8\% do valor total de produção de frutas em 2014. Nesse mesmo ano produziu $11,2 \%$ de toda uva produzida nacionalmente sendo considerado o maior produtor de uva do Brasil (IBGE, 2014).

As lavouras no município são irrigadas através de canais de irrigação que partem do Rio São Francisco. Segundo dados da Companhia de Desenvolvimento dos Vales do São Francisco e do Parnaíba (CODEVASF), Petrolina-Juazeiro é o polo de irrigação mais desenvolvido do vale do São Francisco.

O Aeroporto de Petrolina Senador Nilo Coelho é um importante acesso aéreo para o sertão nordestino e é habilitado para o tráfego aéreo internacional de cargas o que permite o transporte dos produtos agrícolas para o exterior. Este se localiza em posição estratégica entre as sedes das regiões metropolitanas de Recife, Salvador, Teresina e Fortaleza. 
Próximo ao município de Petrolina também está localizada a Usina Hidrelétrica de Sobradinho. O aproveitamento hidrelétrico do Rio São Francisco constitui a base para o suprimento de energia da região nordeste. A Usina Hidrelétrica de Sobradinho (UHE Sobradinho) foi inaugurada em 1979 e é operada pela Companhia Hidrelétrica do São Francisco (CHESF). Se localiza a $35 \mathrm{Km}$, em linha reta, a jusante do Rio São Francisco da sede do município de Petrolina. Ela possui um potencial outorgado de 1.050 MW (ANA, 2015b).

A Barragem de Sobradinho tem capacidade de armazenamento de 34,1 bilhões de litros de água, sendo que é o maior reservatório hidrelétrico da bacia do Rio São Francisco e um dos maiores do Brasil. Devido ao seu tamanho considerável desempenha um importante papel na região nordeste, não só para fins de geração de energia elétrica, mas também pode contribuir para fins de abastecimento; regularidade da navegação; irrigação, através de canais de irrigação; e lazer. A eclusa existente na Barragem de Sobradinho garante a manutenção de um trecho navegável importante que liga Pirapora (MG) aos portos fluviais de Juazeiro (BA) e Petrolina (PE) (ANA, 2015b).

O reservatório de água se estende do município de Barra a Juazeiro, ambos localizados no estado da Bahia, possui um espelho d'água de $4.214 \mathrm{Km}^{2}$. Durante o ano sofre grande variação de nível d'água devido a forte estiagem existente na região, sendo que o espelho d'água chega a diminuir 70\% no pico da seca (MOURA-JUNIOR et al., 2011).

O município de Petrolina encontra-se em pleno desenvolvimento econômico e social e vem ganhando importante notoriedade no cenário estadual, regional e nacional. 


\section{CAPÍTULO 3}

\section{REFERENCIAL TEÓRICO}

\subsection{Recarga Artificial em Meio Fraturado}

$\mathrm{O}$ crescimento dos centros urbanos e de atividades ligadas à agricultura e a indústria nos séculos XX e XXI têm gerado um constante aumento da demanda por recursos hídricos no mundo. Os reservatórios de água subterrânea tem se apresentado como fontes seguras de água o que vem aumentado significativamente sua exploração. A retirada excessiva de água e em taxas muito superiores à taxa de recarga natural dos aquíferos ocasiona o rebaixamento do nível d'água. Além de que, a inadequada utilização dos aquíferos pode causar danos irreversíveis aos mesmos. Holländer et al. (2007) relata que parte considerável da demanda crescente de água do mundo no século XXI terá de ser satisfeita com o crescimento na capacidade de armazenamento de água. Barbosa \& Mattos (2008) explanam que "uma das principais formas de recuperação de aquíferos se dá através da recarga artificial e intencional". Países como Israel já incluíram a recarga artificial nas ferramentas de estratégia de gestão de recursos hídricos (WOLF et al., 2007).

Reconhece-se como recarga artificial o conjunto de técnicas de gestão que potencializam a recarga de aquíferos. Segundo Poehls \& Smith (2009), tais técnicas visam à transferência intencional de água superficial para dentro do aquífero em taxas superiores a recarga natural com o objetivo de aumentar a disponibilidade hídrica e melhorar a qualidade dos recursos hídricos subterrâneos. Comumente é feita durante os períodos chuvosos visando recuperar recargas abaixo do esperado ou expandir a quantidade de água disponível no período seco.

Custodio \& Vilaró (1983) definem recarga artificial como um conjunto de técnicas cujo objetivo principal é permitir uma melhor explotação dos aquíferos pelo aumento de seus recursos e criação de reservas, mediante intervenção direta ou indireta no ciclo natural da água. De maneira complementar Fetter (2001) relata que a recarga artificial pode ser utilizada para expandir a quantidade de água disponível ampliando o escopo de ações na gestão da água subterrânea.

Tem se utilizado na literatura internacional o termo MAR (Managed Aquifer Recharge) para designar recarga artificial. A justificativa para a mudança de nome utilizada por Wolf et al. (2007) é que conotações negativas do termo "artificial" estão sendo utilizadas, o que sugere que um novo nome seja utilizado. As conotações são decorrentes de uma sociedade mais consciente e participativa na gestão dos recursos hídricos (WOLF et al., 2007).

Os objetivos mais comuns para a aplicação das técnicas de recarga artificial englobam aspectos ligados à quantidade (como armazenamento de água e recuperação de aquíferos sobreexplotados), qualidade de água (como recuperação de aquíferos contaminados e armazenamento ou tratamento de efluentes) e gestão ambiental (como controle de intrusão salina e subsidência de solo). Os objetivos específicos são citados a seguir:

- Armazenar água para a garantia da segurança hídrica. Ou seja, garantir disponibilidade hídrica em quantidade e qualidade suficientes para suprir as demandas de usos múltiplos dentro da visão de desenvolvimento sustentável (BROWN \& KEYS, 1985; 
GOLDSHMID, 1974; STAMOS et al., 2013; PICOT-COLBEAUX et al., 2013; CUSTODIO \& VILARÓ, 1983);

- Restaurar aquíferos com superexplotação prolongando sua vida útil (BROWN \& KEYS, 1985; STAMOS et al., 2013; BHATTACHARYA, 2010; PICOT-COLBEAUX et al., 2013; CUSTODIO \& VILARÓ, 1983);

- Garantir o abastecimento em períodos de estiagem (GOLDSHMID, 1974; PICOTCOLBEAUX et al., 2013; CUSTODIO \& VILARÓ, 1983; FETTER, 2001);

- Armazenamento de água local ou importada e servir como reservatório regulador do aquífero (GOLDSHMID, 1974; CUSTODIO \& VILARÓ, 1983);

- Utilizar o aquífero como conduto de distribuição de água quando já existe uma rede de poços apropriada (GOLDSHMID, 1974; CUSTODIO \& VILARÓ, 1983);

- Melhorar a qualidade da água do aquífero (STAMOS et al., 2013; PICOT-COLBEAUX et al., 2013; CUSTODIO \& VILARÓ, 1983);

- Descarte de águas residuais (CUSTODIO \& VILARÓ, 1983);

- Promover o tratamento de efluentes (BARBOSA \& MATTOS, 2008);

- Diluir águas do aquífero controlando sua salinidade (CUSTODIO \& VILARÓ, 1983);

- Reverter quadros de intrusão salina e contaminação criando barreiras hidráulicas apropriadas (ABERBACH, 1967; CUSTODIO \& VILARÓ, 1983);

- Controlar a subsidência do solo por excesso de bombeamento (CUSTODIO \& VILARÓ, 1983);

- Mistura de águas de diferentes qualidades e renovação da água subterrânea (STAMOS et al., 2013; CUSTODIO \& VILARÓ, 1983) e;

- Armazenar água de rios durante períodos de enchentes extremas e controle de enchentes (BARBOSA \& MATTOS, 2008).

Do ponto de vista legal do Brasil, o Conselho Nacional de Recursos Hídricos (CNRH), por meio da resolução $n^{\circ} 153$ de 17 de dezembro de 2013, estabelece critérios e diretrizes para a implantação de recarga artificial de aquíferos no território brasileiro. Entende-se por implantação as fases de planejamento, implantação, operação, manutenção e avaliação da recarga artificial. Segundo o CNRH, recarga artificial é a introdução não natural de água em um aquífero, por intervenção antrópica planejada, por meio da construção de estruturas projetadas para este fim (IBAMA, 2014).

O conceito de práticas conservacionistas, presente na Resolução no 153 de 2013 do $\mathrm{CNRH}$, que é definido como procedimentos em que se recorre a estruturas artificiais tendo como principais objetivos conter os efeitos da enxurrada, disciplinar o escoamento e favorecer a infiltração local da água no solo pode ser considerado um tipo de recarga artificial (IBAMA, 2014).

Barbosa \& Mattos (2008) relatam a ocorrência da chamada "recarga artificial acidental" que consiste nas entradas adicionais de água para o aquífero que ocorrem como consequência de outras práticas como: disposição de efluentes em fossas sépticas não impermeabilizadas, infiltração em aterros sanitários e campos excessivamente irrigados, escoamento superficial de áreas urbanas, rupturas em encanamentos de sistemas de abastecimento de água e esgoto e demais vazamentos.

A escassez de água é um fator limitante para o desenvolvimento social e econômico em muitas regiões do mundo. A regularização da capacidade de acumulação de água pode auxiliar 
no desenvolvimento desses locais garantindo o adequado abastecimento da população por períodos prolongados. $\mathrm{O}$ armazenamento de água na superfície está ligado a grandes perdas por evaporação e dificuldades de locação de bons reservatórios em algumas regiões. Os aquíferos são inestimáveis fontes de suprimento de água e o armazenamento de recursos hídricos no subsolo possui vantagens em relação aos superficiais, tais como: tempo de permanência prolongado, sem perda de capacidade de armazenamento por sedimentação (como no leito de rios), perdas reduzidas por evaporação, menor vulnerabilidade a contaminação, ausência de perigos de rompimento de barragens e inundações, entre outros.

O armazenamento de água nos aquíferos pelos processos de recarga artificial cria um acumulo subterrâneo de água através da elevação do nível freático. As dimensões de tal elevação e sua taxa de crescimento dependem do tamanho e formato da bacia de recarga, da duração e taxa de recarga, das características hidráulicas da zona vadosa e saturada, do método utilizado e das características das rochas em subsuperfície (FREEZE \& CHERRY, 1979). As Figuras 3.1 e 3.2 esquematizam de forma simplificada o comportamento das elevações dos níveis freáticos decorrentes de sistemas de recarga artificial com injeção superficial e subterrânea (através da injeção em poços) e em diferentes contextos hidrogeológicos. Ambas as figuras representam aquíferos intergranulares.

Os métodos para aplicação da recarga artificial são variados e o sucesso dos mesmos depende de sua adequada escolha. Os fatores que influenciam diretamente na escolha do método e na aplicação da recarga artificial são: tipo de solo, perfil litológico da camada insaturada e do aquífero, características hidrogeológicas da área, níveis de água, gradiente regional, volumes estimados da recarga natural, características de poços e bombeamentos existentes, parâmetros hidrodinâmicos do aquífero $(K, T$ e $S)$, composição química das águas do aquífero e da água utilizada na recarga, relevo, objetivos pretendidos, condições socioeconômicas da região, poluição existente ou potencial oriunda de quaisquer fontes e contaminantes do solo que possam ser lixiviados durante a recarga (CUSTODIO \& VILARÓ, 1983; BARBOSA \& MATTOS, 2008). As técnicas mais utilizadas para recarga artificial de aquíferos livres são bacias de infiltração ou de recarga, já para aquíferos confinados, injeções diretas em poços é o mais utilizado (POEHLS \& SMITH, 2009) (Figura 3.3).

(a)

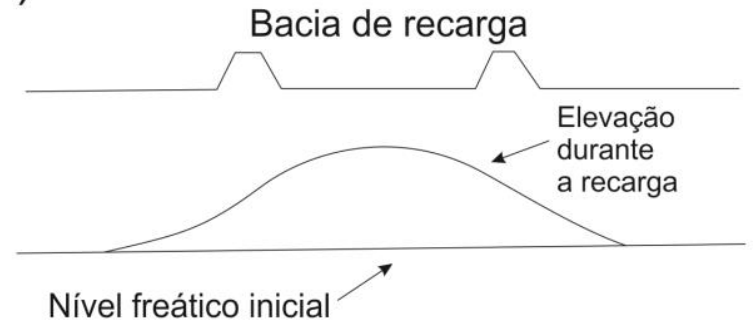

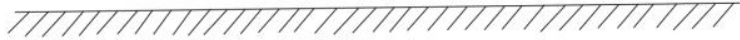

(b)

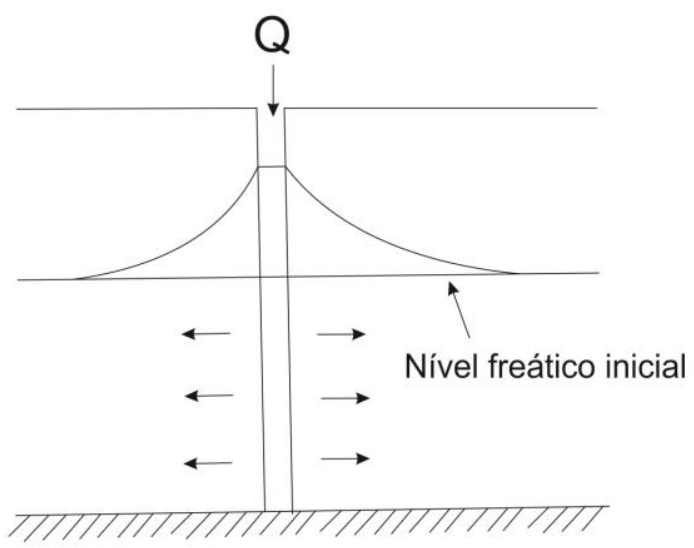

Figura 3.1 - Esquema simplificado das respostas esperadas no nível freático com a recarga artificial por bacias de recarga (a) e por poços de injeção (b) (Adaptado de CUSTODIO \& VILARÓ, 1983). 


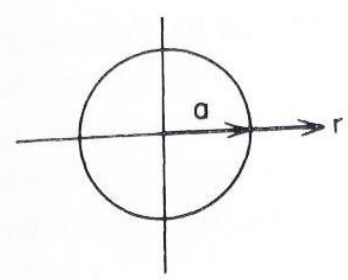

(a)

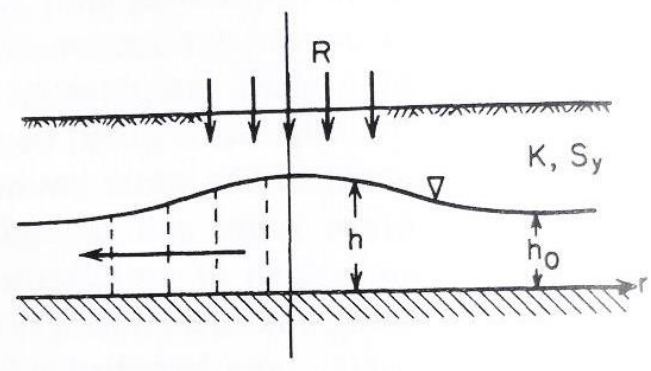

(b)

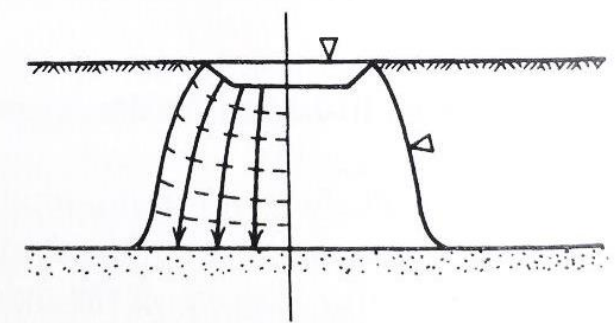

Figura 3.2 - Comportamento simplificado do nível freático em 2 contextos hidrogeológicos simples relativo a recarga artificial em bacia de infiltração circular de raio a. Onde $R$ é a recarga, $h_{0}$ é o nível freático inicial, $h$ é o nível freático máximo após a recarga, $K$ é a condutividade hidráulica e $S_{y}$ é a vazão específica do aquífero livre aflorante. Esse modelo é restrito para aquíferos homogêneos, isotrópicos, onde $R<<K$ e para uma taxa de recarga constante no tempo e no espaço. (a) Representa a elevação do nível freático em aquífero livre horizontal em contato na base com formação impermeável. (b) Representa a recarga artificial em camada pouco permeável aflorante em contato na base com camada permeável

(Adaptado de FREEZE \& CHERRY, 1979).

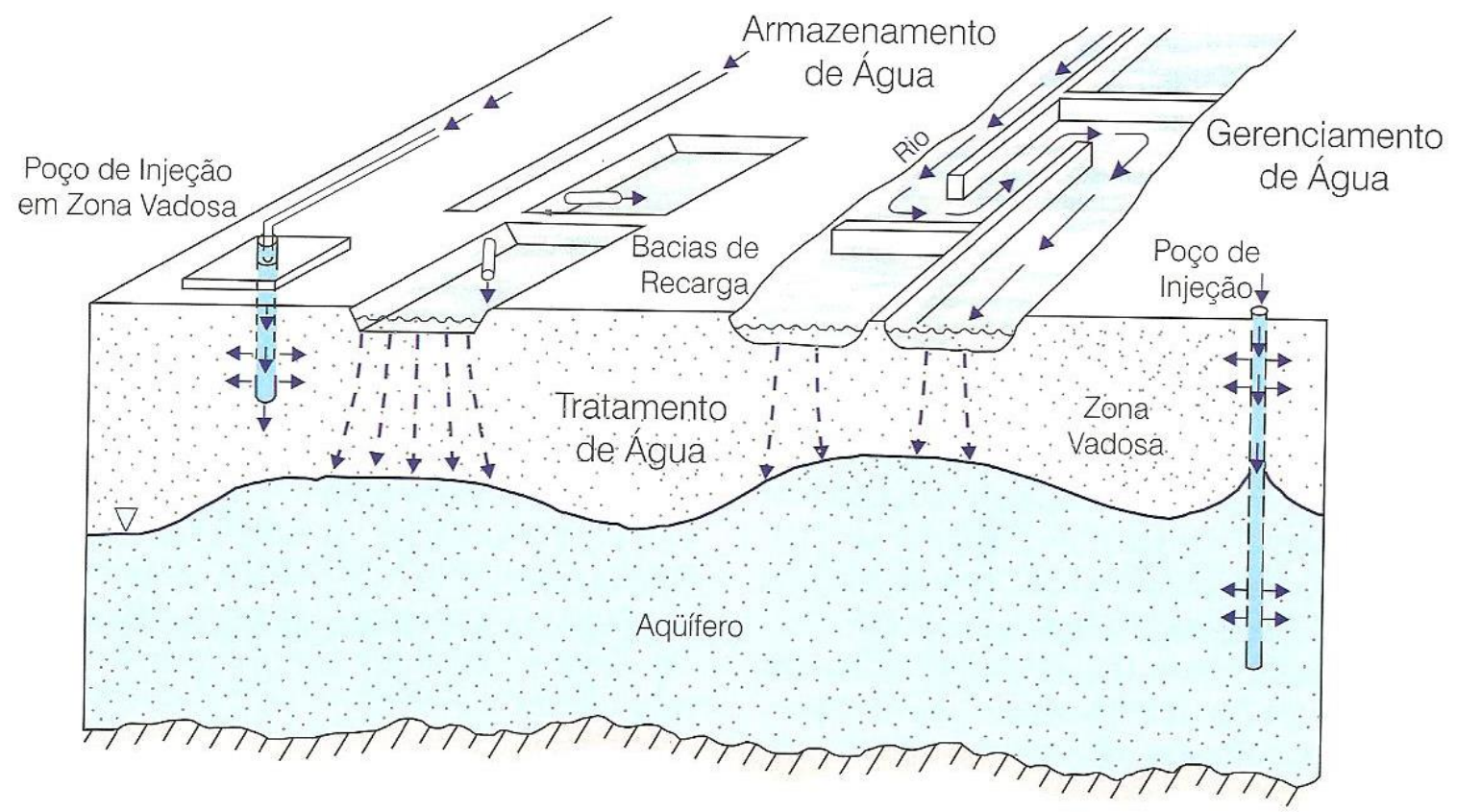

Figura 3.3 - Síntese de métodos comumente utilizados para recarga artificial de aquíferos. Os mesmos serão descritos logo em seguida (Adaptado de FEITOSA et al., 2008). 
Abaixo serão descritos de maneira simplificada alguns métodos de recarga artificial comumente utilizado.

BARREIRA DE INFILTRAÇÃO - Consiste no bombeamento de poços próximo a rios (Figura 3.4). É criada uma linha de poços pouco distantes e paralelos ao leito do rio. O bombeamento no conjunto de poços rebaixa o nível piezométrico e consequentemente o nível de água no rio, induzindo a água do rio a infiltrar no aquífero. De modo a assegurar uma purificação satisfatória da água do rio pelo solo o tempo de infiltração deverá ser entre 30 e 60 dias (BARBOSA \& MATTOS, 2008). Quando a água do rio começa a recarregar o aquífero, as partículas em suspensão são filtradas atuando como selantes para o leito. Assim, rios que possuem águas com grande quantidade de material em suspensão podem não ter sucesso com essa técnica.
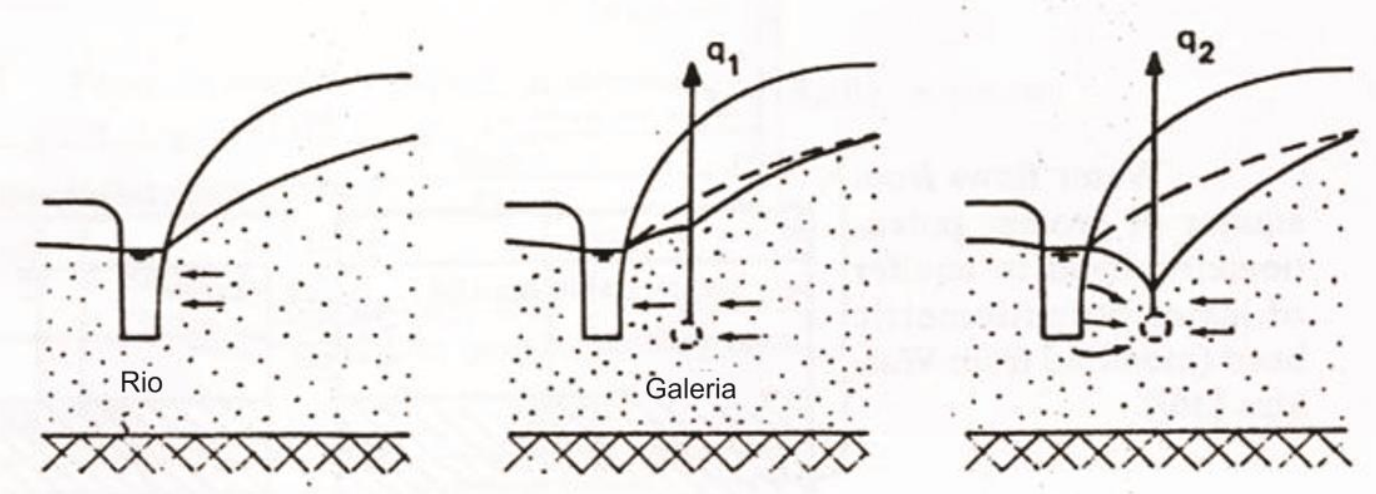

Figura 3.4 - Processo de funcionamento de barreira de infiltração. Um método de recarga artificial que consiste no bombeamento próximo a rios.

BACIAS DE INFILTRAÇÃO (Bacias de recarga) - Consiste na descarga de água em bacias escavadas no solo. Este método é indicado para aquíferos livres e sem a presença de níveis impermeáveis na zona vadosa. É importante a verificação da presença de áreas contaminadas na zona não saturada e no aquífero nas proximidades do sítio de recarga artificial. A recarga nesse método é feita com um grande volume de água infiltrando em uma pequena área o que resulta em uma elevação local do nível freático. Durante a recarga, a elevação cresce e nos períodos de repouso ela decresce. Após um tempo da instalação do sistema é comum que ocorra a redução nas taxas de infiltração devido à colmatação das paredes e do fundo da bacia por sedimentos finos e atividade biológica (BARBOSA \& MATTOS, 2008; FETTER, 2001).

TRICHEIRAS DE INFILTRAÇÃO - Consistem em escavações alargadas com 1 metro de largura e cerca de 10 metros de profundidade. As trincheiras são indicadas para terrenos que possuem níveis permeáveis em profundidade (entre 5 e 15 metros) e, diferentemente das bacias de infiltração, são preenchidas por areia grossa ou cascalho o que facilita a infiltração da água de recarga. A água utilizada na recarga artificial por esse método deve conter baixo teor de sólidos em suspensão para evitar a diminuição da porosidade e permeabilidade do sistema (BARBOSA \& MATTOS, 2008). 
REPRESAS PERENES - Armazenamento de grande quantidade de água em áreas escavadas com grandes profundidades. Podem ser utilizadas como fonte direta de água ou como contribuições para a recarga de aquíferos (BARBOSA \& MATTOS, 2008).

VALAS E SULCOS (ou canais) - São bacias de infiltração longas e estreitas, sendo que sua largura é inferior a sua profundidade. Podem ser projetadas para se adaptar a topografia e a condições geológicas específicas (BARBOSA \& MATTOS, 2008).

IRRIGAÇÃO - Quando a quantidade de água utilizada na irrigação é superior à necessária para as plantas, o excesso de água percola pela zona vadosa e uma parte dela acaba recarregando o aquífero. Por ser um método difuso, tende a elevar o nível d'água em uma área bastante extensa (FETTER, 2001).

ALAGAMENTO (surface spreading) - Utilizado onde a topografia é relativamente plana, consiste no desvio de água de rios e canais e seu descarrego em grandes áreas planas. As taxas de infiltração são maiores em áreas com vegetação e solo preservados. Esse método tende a elevar o nível d'água em uma área bastante extensa. As circunstâncias ideais para implantação do método são: camadas superiores do solo permeáveis, nível d'água não tão raso, relevo plano, transmissividade do aquífero com valores suficientes para espalhamento da água (BARBOSA \& MATTOS, 2008; FETTER, 2001).

MODIFICAÇÕES EM LEITOS DE RIOS - São construídas barreiras no leito dos rios de forma a retardar o escoamento da água aumentando assim a infiltração. O material utilizado pode ser os sedimentos aluvionares do próprio rio (BARBOSA \& MATTOS, 2008).

POÇOS DE INJEÇÃO NA ZONA VADOSA - Barbosa \& Mattos (2008) verificaram um aumento no interesse na utilização de poços secos de largo diâmetro $(1$ a $2 \mathrm{~m})$ destinados à recarga de aquíferos livres. São normalmente perfurados em zonas permeáveis da zona não saturada dos aquíferos. Outra variação desse método, citado pelos mesmos autores, consiste em um poço com cerca de 2 metros de profundidade que é preenchido com areia ou outro material permeável, revestimento de plástico e fundo coberto com um nível de cascalho ou de tubos drenantes.

POÇOS DE INJEÇÃO NA ZONA SATURADA - Consiste na injeção direta de água em poços. É uma boa alternativa para recarga artificial em aquíferos confinados, em profundidade ou que apresentem níveis não permeáveis na zona vadosa. A tecnologia de implantação e os requisitos de qualidade da água de recarga são mais exigentes do que nos sistemas de recarga a superfície. Os custos envolvidos são elevados tanto no que se refere à construção do poço quanto em relação à proteção da qualidade de água do aquífero (BARBOSA \& MATTOS, 2008).

OBSERVAÇÃO: Na literatura internacional se utiliza o termo ARS (Aquifer Storage and Recovery) para designar a injeção direta em poços. Os poços ASR são utilizados tanto para injeção da água de recarga quanto para explotação da mesma em períodos alternados. 
POÇOS DE UNIÃO OU POÇOS CONJUNTIVOS (conjuctive well) - Os poços de união são baseados no princípio de que quando a água subterrânea é bombeada de um aquífero confinado profundo e sua superfície potenciométrica é rebaixada a um nível abaixo do lençol freático do aquífero livre sobrejacente, a água do aquífero livre é drenada para dentro do poço e flui para o aquífero confinado profundo (Figura 3.5). A água utilizada para recarga é a água do próprio aquífero o que diminui o risco de contaminação e colmatação nos filtros.

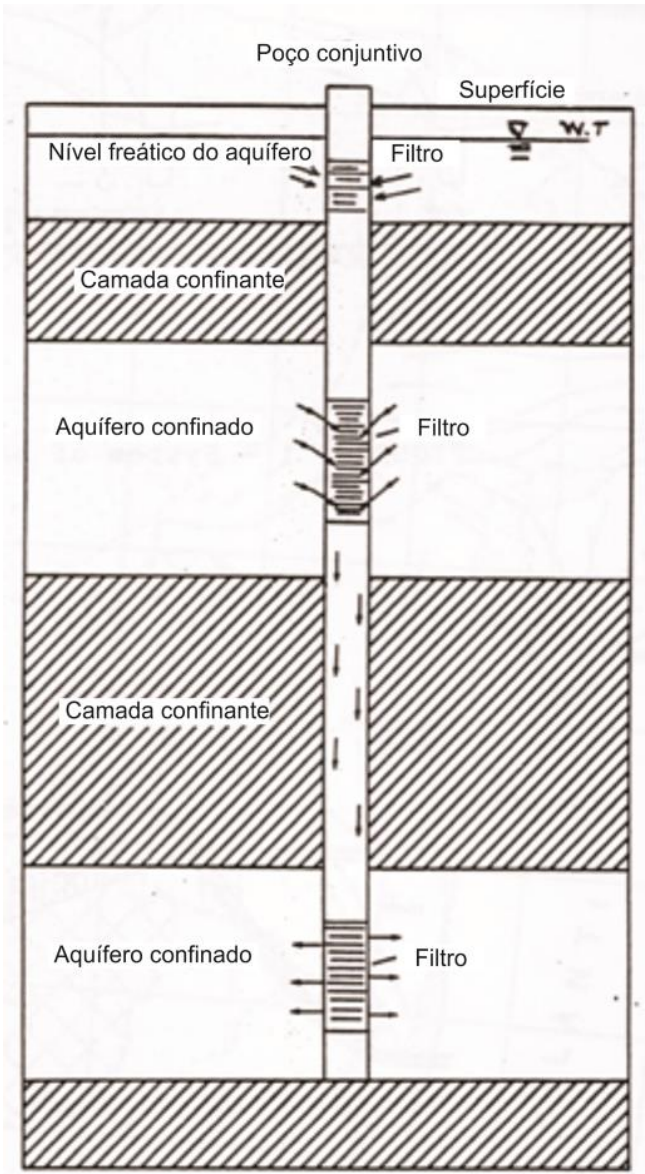

Figura 3.5 - Exemplo de funcionamento de poço de união.

A hidrogeologia é um fator decisivo para a escolha do local e da metodologia a ser utilizada. O objetivo é identificar aquíferos que armazenem grandes quantidades de água e que não permitam sua rápida dispersão. Preferencialmente tais aquíferos devem ter condutividade hidráulica vertical alta e condutividade hidráulica horizontal moderada, embora a existência de tais condições em ambientes naturais seja rara (GRÜTZMACHER \& KUMAR, 2012).

Os aquíferos fraturados são heterogêneos e anisotrópicos, o que dificulta a localização e implantação de sistemas de recarga artificial. O solo que recobre as fraturas absorve e dispersa grande parte da água de recarga (chuva). Nesses casos as fraturas e lineamentos devem ser visados. Em caso de aquíferos profundos o único método capaz de atingi-los é a injeção em poços (GRÜTZMACHER \& KUMAR, 2012).

Algumas dificuldades na aplicação da recarga artificial em aquíferos fraturados são (MARTIN \& DILLION, 2002):

- A taxa de injeção é lenta em poços de injeção (ASR);

- As opções de remediação em caso de entupimento no poço são limitadas; 
- Dependendo da densidade e da interconectividade das fraturas a capacidade de armazenamento pode ser limitada e a dispersão por longas distâncias pode ocorrer;

- A recuperação em caso de contaminação é difícil. Por isso, o cuidado com a escolha adequada do local de implantação da recarga e com a qualidade da água injetada deve ser redobrado;

- As fraturas correm risco de sofrerem acomodação devido à recarga.

Algumas vantagens da aplicação da recarga artificial em aquíferos fraturados são (MARTIN \& DILLION, 2002):

- Resistência à pressão hidráulica. A injeção da recarga em poços sobre pressão pode ser feita com a chance reduzida de ter um colapso da formação nas paredes do poço;

- Os poços de injeção podem ter aberturas maiores o que permite a injeção de água com um teor levemente mais elevado de material em suspensão o que diminui os custos no tratamento da água pré-injeção. Deve-se ter atenção para não haver entupimento das fraturas do aquífero.

Um aspecto que deve ser levado em conta antes e durante a realização da recarga artificial é o entupimento dos filtros dos poços de injeção e das fraturas ou a diminuição da permeabilidade nos métodos de infiltração superficiais (clogging). Em geral a presença de material em suspensão pode afetar a capacidade de infiltração entupindo os filtros de poços de recarga e as fraturas ou diminuindo a permeabilidade na base e nas paredes das escavações dos métodos superficiais. Custodio \& Vilaró (1983) citam que em geral até $100 \mathrm{mg} / \mathrm{L}$ de sólidos em suspensão é admissível para sistemas de recarga artificial por trincheiras. A penetração de sedimentos e a consequente diminuição da taxa de infiltração da recarga no aquífero dependem da granulometria das rochas e dos solos, da granulometria dos sedimentos em suspensão, da velocidade de infiltração e das condições da recarga se com fluxo (rios e córregos) ou sem fluxo (trincheiras e tanques de recarga).

O entupimento dos filtros e das fraturas pode ocorre devido a: presença de sedimentos finos, material orgânico, desenvolvimento de colônias de bactérias, formação de precipitados devido a interação da água de recarga com a água do aquífero, precipitação de ferro devido a diferenças de $\mathrm{pH}$ e Eh entre a água de recarga e as condições iniciais do aquífero e compactação mecânica do aquífero devido a alta pressão da injeção de água (FETTER, 2001).

A presença de microrganismos deve ser verificada para não haver contaminação das águas do aquífero e evitar o entupimento biológico das bacias de recarga por desenvolvimento de colônias de algas. Custodio \& Vilaró (1983) relatam que em geral o limite é de $10 \mathrm{mg} / \mathrm{L}$ de algas e 100.000 colônias bacterianas por $\mathrm{cm}^{3}$ na água de recarga. Em alguns casos é necessário tratamento prévio das águas que serão infiltradas.

A qualidade da água utilizada na recarga é um tópico de extrema importância para o sucesso do sistema. Esta depende das características hidrogeológicas e dos objetivos específicos do procedimento. $\mathrm{O}$ processo de infiltração da água de recarga na zona vadosa, geralmente representada pelos solos nos aquíferos fraturados, já ocasiona uma filtração e a mudança de parâmetros químicos e físicos de maneira que a água que chega à zona saturada, e efetivamente é misturada com a água do aquífero, possui características distintas da água injetada na superfície. A capacidade de tratamento do terreno é limitada e depende das características do meio, da qualidade inicial da água injetada, do oxigênio disponível e do tempo de residência. É preciso 
estar atento ao comportamento de certos contaminantes e a precipitação de sais que diminuem a permeabilidade na superfície de recarga (CUSTODIO \& VILARÓ, 1983).

A interação química das águas de recarga com as águas do aquífero pode gerar mudanças no $\mathrm{pH}$ e Eh do meio causando precipitação de sais como carbonato de cálcio, óxido e hidróxido de ferro e manganês, além de sulfatos e outros sais. Os sais podem preencher as fraturas diminuindo o espaço para o fluxo de água. O controle periódico da qualidade das águas do aquífero e da água da recarga é imprescindível para evitar transtornos futuros. Custodio \& Vilaró (1983) e Banton \& Klisch (2007) apresentam tabelas com a simulação das mudanças sofrida pela água no processo de infiltração em aquífero intergranular e fraturada, respectivamente (Figura 3.6). Os primeiros autores recomendam que a água utilizada para recarga não supere certos limites para parâmetros químicos, tenha um gosto e odor toleráveis, baixo DQO, e não contenha impurezas industriais não degradáveis (CUSTODIO \& VILARÓ, 1983).

\begin{tabular}{|l|c|c|}
\hline & $\begin{array}{c}\text { Água de } \\
\text { recarga }\end{array}$ & $\begin{array}{c}\text { Poço a } 10 \mathrm{~m} \\
\text { de distância }\end{array}$ \\
\hline D.B.O. mg/L & 20 & 0,2 \\
D.Q.O. mg/L & 55 & 15 \\
Amônio mg/L N & 25 & 1,9 \\
Nitrato $\mathrm{mg} / \mathrm{L} \mathrm{N}$ & 0,1 & 0 a 25 \\
Nitrito $\mathrm{mg} / \mathrm{L} \mathrm{N}$ & Traços & 0,4 a 0,1 \\
Nitrogênio orgânico mg/L N & 2 & 0,3 \\
Fósforo mg/L P & 20 & 5 \\
Boro mg/L B & 0,5 & 0,5 \\
Sais totais mg/L & 900 & 950 \\
pH & 8,0 & 7,7 \\
Coliformes MPN/100 ml & $10^{6}$ & 0 a 33 \\
Coliformes fecais MPN/100 ml & $10^{6}$ & 0 a 13 \\
SAR = rNa / $\sqrt{ }[(\mathrm{rMg}+\mathrm{rCa}) / 2]$ & 4,6 & 4,6 \\
\hline
\end{tabular}

\begin{tabular}{||l|l|l|l||}
\hline \multicolumn{1}{|c|}{ Parameter } & $\begin{array}{c}\text { Recharge Water } \\
\text { (mg/L) }\end{array}$ & $\begin{array}{c}\text { Native } \\
\text { Groundwater } \\
\text { (mg/L) }\end{array}$ & $\begin{array}{c}\text { RecoveredWater } \\
\text { (mg/L) }\end{array}$ \\
\hline Calcium & 5.6 to 6.4 & 17.5 & 9.9 to 15 \\
\hline Magnesium & 1.9 to 2.5 & 7.3 & 3.8 to 5.8 \\
\hline Sodium & 2 & 24 & 10 to 19 \\
\hline Silica & 27 to 29 & No data & 46 to 59 \\
\hline Iron & $<0.1$ & $<0.05$ & $<0.1$ \\
\hline Manganese & $<0.001$ to 0.0007 & 0.011 & 0.0041 to 0.0055 \\
\hline Chloride & 1.3 to 1.5 & 2.3 & 1.5 to 1.6 \\
\hline Alkalinity as $\mathrm{CaCO}^{3}$ & 25 to 30 & 120 & 56 to 110 \\
\hline Sulfate & 1.0 to 1.2 & 5.5 & 2.1 to 4 \\
\hline
\end{tabular}

Figura 3.6 - Exemplos de alterações nos parâmetros físico e químicos das águas subterrâneas sofridos durante o processo de recarga artificial. À esquerda em aquífero poroso (Adaptado de CUSTODIO \& VILARÓ, 1983) e a direita em aquífero fraturado (BANTON \& KLISCH, 2007).

O uso de recarga artificial é bem conhecido na literatura. Porém, as informações se concentram em aquíferos porosos (ABERBACH, 1967; HARPAZ \& BEAR, 1964), sendo que são poucas as informações sobre aquíferos fraturados e cársticos. Abaixo serão expostos alguns exemplos de aplicações de recarga artificial em aquíferos fraturados e cársticos e suas peculiaridades.

Wolf et al. (2007) relata a utilização de recarga artificial em aquífero cárstico nas proximidades de Amã, na Jordânia. A porosidade do aquífero é classificada como fissurocárstica. O método de recarga utilizado são barragens superficiais. Os autores relatam elevações do nível da água em poços próximos à barragem de $15 \mathrm{~m}$ e taxas de recarga de 1 a $<0,05 \mathrm{~m} / \mathrm{dia}$ dependendo do nível de água na barragem. Os problemas relatados estão relacionados à alta heterogeneidade do meio, a rápida dispersão da água injetada e tempo de retenção insuficiente quando o aquífero é drenado por mananciais nas suas proximidades. A capacidade de armazenamento pode diminuir devido à rápida dispersão da água. Tais fatores resultam em uma dificuldade de retenção e armazenamento do aquífero.

Picot-Colbeaux et al. (2013) em trabalho que utiliza métodos de modelagem para avaliação quantitativa dos efeitos da recarga artificial na bacia hidrográfica Maheshwaram na Índia, cita a utilização de recarga artificial para minimizar os efeitos da superexplotação e melhorar a qualidade das águas em aquífero fraturado.

Há relatos da implantação de recarga artificial pelo método ASR (Aquifer Storage and Recovery) em aquífero fraturado na região noroeste dos EUA nos estados de Washington e Oregon. O método consiste na construção de poços que são utilizados tanto para injeção da água 
de recarga quanto para explotação da mesma em períodos alternados. O aquífero explotado é o Sistema Aquífero Basalto Rio Columbia que ocorre nos derrames de basalto do Grupo Rio Columbia. Tais basaltos são datados do mioceno e encobertos por sedimentos inconsolidados de aluvião, sedimentação eólica e de planícies de inundação. O acumulo de água ocorre nas chamadas pelos autores de "interflow zones" que são os contatos entre os derrames de basalto. Essas zonas possuem de 5 a $10 \mathrm{~m}$ de espessura, são fraturadas, vesiculares, podem estar preenchidas por material sedimentar ou pillow lavas. O interior dos derrames de basalto costuma ser denso e não fraturado. Fraturamento causado pelo alívio de pressão pode favorecer a conexão hidráulica entre as "interflow zones" (BANTON \& KLISCH, 2007; EATON \& WINSHIP, 2007).

Um dos relatos de aplicação nessa região é nas proximidades de Walla Walla em Washington, onde foram implantados 2 poços ASR. O Sistema Aquífero Basalto Rio Columbia, na área, é confinado tanto por camadas de silte e argila das porções superiores, como pelos próprios derrames de basalto, ambos funcionam como aquitardes. Outro fator curioso do local é que o espesso pacote de basalto é compartimentado por falhas que o divide em grandes blocos separados hidraulicamente. O sistema de recarga artificial funciona desde 1999 e já recarregou cerca de 14,4 bilhões de litros de água para o aquífero (BANTON \& KLISCH, 2007).

A cidade de Beaverton, no estado de Oregon, também possui uma história de sucesso na implantação de recarga artificial pelo método ASR em basaltos fraturados. O sistema funciona desde 1999 e possui 3 poços ASR. Anualmente são armazenados no aquífero 170 mil litros de água potável oriunda de uma planta de tratamento de água. A água fica armazenada para ser utilizada nos picos de consumo da cidade e tem uma capacidade de fornecer $22.700 \mathrm{~m}^{3} / \mathrm{dia}$ de água (EATON \& WINSHIP, 2007).

Outro exemplo de aplicação de recarga artificial em aquíferos fraturados é no estado de Utah, também nos EUA. A área possui clima árido e alta taxa de evaporação (os autores relatam que foram evaporados cerca de 20,9 bilhões de litros de água entre 2002 e 2006). A recarga artificial se deu por um grande reservatório de água denominado Sand Hollow que recarrega o Arenito Navajo que possui dupla porosidade (intergranular e fraturado). Níveis estáticos foram medidos mensalmente em uma rede de poços de monitoramento nas proximidades do reservatório para monitorar o funcionamento do sistema. Além disso, foram coletados dados meteorológicos, de fluxo em subsuperfície, temperatura e altitude do nível de água do reservatório, entre outros. Entre 2002 e 2006, o volume estimado de recarga foi de 62,9 bilhões de litros de água, sendo que a recarga anual variou de 11,1 a 17,2 bilhões de litros. Não foram utilizados dados de precipitação no cálculo da recarga. Os autores justificam afirmando que as altas taxas de evaporação juntamente com a alta permeabilidade dos solos dificilmente permitem que a água da chuva alcance níveis profundo sendo seu escoamento lateral predominante. Além disso, as chuvas são raras e o quantitativo de água das precipitações é pequeno. Também há relatos de diminuição na taxa de recarga do reservatório com o tempo devido à diminuição da porosidade do leito pela presença de partículas finas e atividade biológica (HEILWEIL et al., 2007).

Em Regent Gardens, na Austrália, um poço ASR foi construído para recarga artificial de aquífero fraturado. As águas do aquífero são salinas e a recarga visa ao armazenamento de água da chuva para evitar inundações. O volume anual de recarga é na ordem de 40 milhões de litros de água e o sistema está em operação desde 1994 (MARTIN \& DILLION, 2002). 
Alguns conceitos hidrogeológicos são relevantes no controle e monitoramento durante a recarga artificial.

Zona de espalhamento (spreading zone) é a região da zona vadosa onde há a propagação da água durante a recarga. A relação entre a condutividade hidráulica vertical e horizontal no aquífero interfere de maneira direta na zona de espalhamento. A possibilidade de fuga horizontal da água da recarga deve ser levada em conta. A criação de uma elevação local do nível freático próximo à zona de infiltração depende da zona de espalhamento (POEHLS \& SMITH, 2009).

Capacidade de infiltração é o volume de água infiltrado por $\mathrm{m}^{2}$ e por tempo. Sua unidade é $\mathrm{m}^{3} / \mathrm{m}^{2} / \mathrm{s}$ ou $(\mathrm{m} / \mathrm{s})$. Também é chamada de velocidade de infiltração. A capacidade de infiltração é função da permeabilidade do terreno no sentido do fluxo e do gradiente hidráulico. Como tais parâmetros variam ao longo do processo de recarga, a capacidade de infiltração também varia (Figuras 3.7 e 3.8 ).

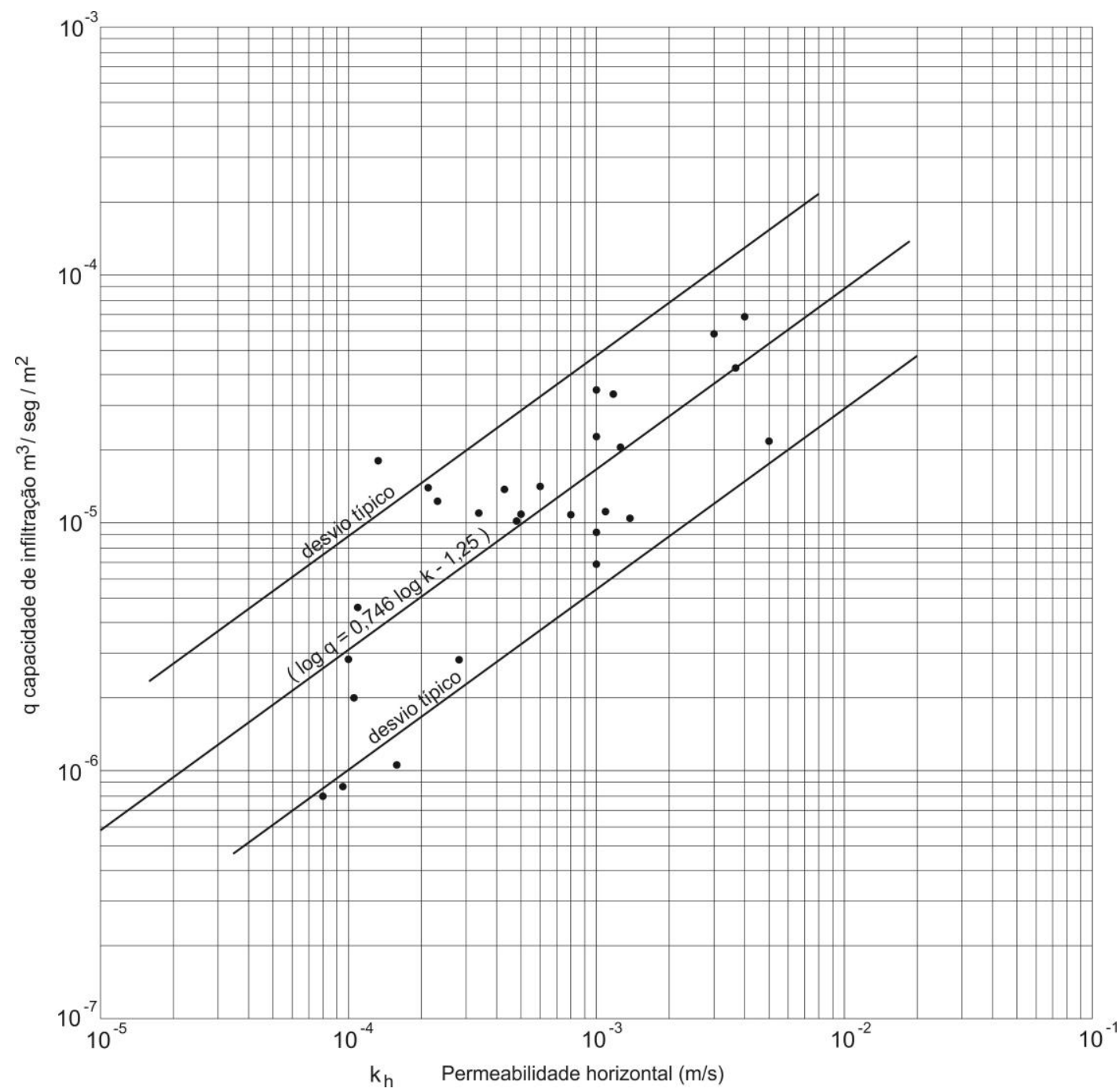

Figura 3.7 - Variação da capacidade de infiltração em função da permeabilidade horizontal (Adaptado de CUSTODIO \& VILARÓ, 1983). 


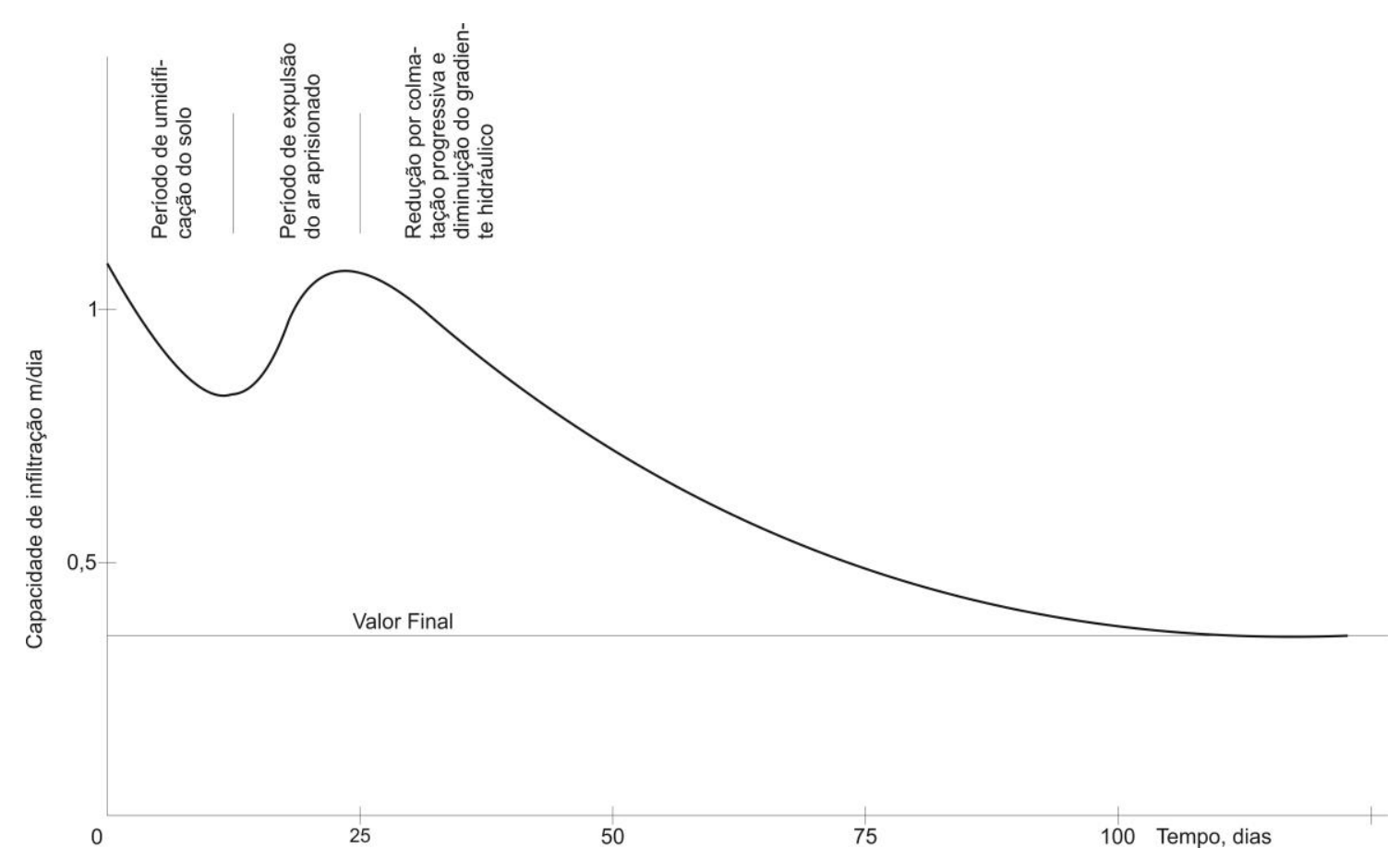

Figura 3.8 - Variação da capacidade de infiltração durante o processo de recarga artificial (tempo) (Adaptado de CUSTODIO \& VILARÓ, 1983).

Após a escolha do método e sua implantação, o monitoramento do sistema de recarga artificial deve ser feito para avaliar a chegada da recarga e a evolução da qualidade da água do aquífero. Devem ser monitorados parâmetros como: volume de água injetada, qualidade da água de recarga, qualidade inicial da água do aquífero, qualidade da água referente à mistura (água final do aquífero), tempo de infiltração da água de recarga, entre outros. Alguns métodos utilizados para o monitoramento do sistema são: balanço hídrico (formulação empírica), modelos físicos (balanço entre água subterrânea e superficial), modelos de circulação da zona saturada (modelos determinísticos), traçadores (químicos, bacteriológicos, orgânicos e isotópicos), análises hidroquímicas, oscilação piezométrica e aplicação da Lei de Darcy ao escoamento em meio saturado. As análises descrevem a percolação da água desde o solo até o aquífero, abordado parâmetros como evapotranspiração, umidade do solo, para obter uma estimativa da recarga, ou utilizam informações piezométricas como indicadores de recarga efetiva (STAMOS et al., 2013; HARPAZ \& BEAR, 1964; BARBOSA \& MATTOS, 2008). 


\subsection{Isótopos}

Uma das grandes contribuições da ciência moderna para os estudos hidrológicos e hidrogeológicos esta sendo o desenvolvimento das técnicas nucleares aplicadas para estudo dos isótopos ambientais (SANTIAGO et al., 2008).

O uso de isótopos em estudos ambientais é muito difundido a nível mundial podendo ser considerado, nos dias de hoje, uma ferramenta tradicional no meio técnico hidrogeológico. Porém, os mesmos não têm sido utilizados de forma substancial no Brasil, havendo ainda certo desconhecimento no meio técnico especializado de suas peculiaridades e mesmo de potenciais situações em que estas técnicas poderiam ser úteis (SILVEIRA \& SILVA JUNIOR, 2002).

A denominação isótopos ambientais se refere aos isótopos que tem ocorrência natural e que acompanham os ciclos naturais do meio ambiente (ciclo hidrológico, entre outros). São assim chamados por serem encontrados de forma generalizada no meio ambiente em quantidades que permitem seu uso como traçadores ou marcadores cronológicos (SILVEIRA \& SILVA JUNIOR, 2002).

No Brasil, os estudos hidrogeológicos recentes com isótopos estão concentrados principalmente nos aquíferos de São Paulo e do Nordeste. O uso dos isótopos restringe-se a datação das águas, sendo poucos os estudos que utilizam os mesmos como traçadores de fluxo e do comportamento da recarga da água subterrânea (SILVEIRA \& SILVA JUNIOR, 2002).

Silveira \& Silva Junior (2002) observam uma tendência a aumentar o uso das técnicas de isótopos nos próximos anos no Brasil, tanto pela ampliação da base laboratorial disponível no país; quanto pela maior facilidade no envio de amostras para laboratórios no exterior que estão oferecendo preços e prazos frequentemente competitivos e vantajosos; e, principalmente, pelo crescente interesse em estudos de isótopos ambientais.

Isótopos são espécies atômicas que possuem em seus núcleos o mesmo número de prótons $(\mathrm{Z})$ - portanto correspondem ao mesmo elemento químico - e diferentes números de nêutrons $(\mathrm{N})$. A massa atômica (A) corresponde à soma de seus prótons e nêutrons, sendo assim, isótopos de um mesmo elemento tem diferentes valores de massa atômica. Como exemplo, podemos utilizar os isótopos estáveis do carbono:

$$
\begin{aligned}
& { }^{12} \mathrm{C} \text { - Possui } 6 \text { prótons e } 6 \text { nêutrons }(\mathrm{A}=12) \\
& { }^{13} \mathrm{C} \text { - Possui } 6 \text { prótons e } 7 \text { nêutrons }(\mathrm{A}=13)
\end{aligned}
$$

Os isótopos instáveis são radioativos e sofrem variações em suas massas (decaimento) ao longo do tempo. As variações são acompanhadas de emissões de energia e partículas subatômicas. Diferentemente dos instáveis, os isótopos estáveis são assim chamados por não alterarem suas massas ao longo de sua existência (MARTINELLI et al., 2009).

Isóbaros são átomos que possuem mesmo número de massa, porém diferentes números de prótons, ou seja, são elementos químicos distintos. É importante conhecer os isóbaros, pois eles podem interferir nos resultados das análises de isótopos quando os aparelhos utilizam a massa para separação dos átomos para medição, como é o caso dos espectrômetros de massa (ALLÈGRE, 2008). 


\subsubsection{Isótopos Estáveis em Hidrogeologia}

A evolução nos estudos e na utilização dos isótopos estáveis está intimamente ligada à evolução da espectrometria de massa. A espectrometria de massa é um dos métodos analíticos mais antigos. A comunidade científica passou a reconhecer a existência dos isótopos no campo dos elementos estáveis a partir de 1920, após Francis William Aston apresentar seu espectrógrafo de raios positivos que usava campos elétricos e magnéticos para separar íons de diferentes massas e focá-los em relação à velocidade de cada íon. Entre 1927 e 1932 foram descobertos os isótopos estáveis do enxofre $\left({ }^{32} \mathrm{~S},{ }^{33} \mathrm{~S}\right.$ e $\left.{ }^{34} \mathrm{~S}\right)$, seguido dos de carbono $\left({ }^{13} \mathrm{C}\right)$, oxigênio $\left({ }^{18} \mathrm{O}\right.$ e $\left.{ }^{17} \mathrm{O}\right)$, nitrogênio $\left({ }^{15} \mathrm{~N}\right)$ e hidrogênio $\left({ }^{2} \mathrm{H}\right)$ (MARTINELLI et al., 2009).

Os isótopos estáveis passaram a ser utilizados como traçadores ambientais, na década de 1930, com o aprimoramento da espectrometria de massa por Alfred Neir e colaboradores (MARTINELLI et al., 2009).

No final da década de 40 o aumento na precisão dos equipamentos de espectrometria de massa permitiu que pesquisadores ligados a Universidade de Chicago desenvolvessem uma série de estudos sobre a variabilidade natural do hidrogênio (Irving Friedman), carbono (Harmon Craig), nitrogênio e oxigênio (Sam Epstein) (MARTINELLI et al., 2009).

A utilização dos isótopos ambientais em estudos hidrogeológicos se iniciou com os trabalhos pioneiros de Urey et al. e Epstein \& Mayeda na década de 50. Uma publicação clássica nos estudos isotópicos de 1947, realizada por Urey, explica e quantifica os efeitos da variação isotópica (fracionamento) em abundâncias naturais. E em 1961, Harmon Craig publica um artigo que descreve os fatores de correções analíticas e padronização dos resultados. Nas décadas de 1960 e 1970, os espectrômetros de massa de razão isotópica (IRMS - Isotope Ratio Mass Spectrometer) se desenvolveram e ocorreu um aumento na capacidade analítica das análises (MARTINELLI et al., 2009; SILVEIRA \& SILVA JUNIOR, 2002).

Nos dias atuais houve uma melhora significativa na precisão das análises e no sistema de preparo e admissão das amostras, sendo que amostras líquidas, gasosas e sólidas podem ser analisadas em fluxo contínuo (MARTINELLI et al., 2009).

No Brasil, os primeiros estudos com isótopos ambientais em águas datam do final da década de 60 e tiveram como alvos principais o nordeste brasileiro, a Amazônia e posteriormente a região sudeste (basicamente o Aquífero Botucatu). No nordeste os estudos foram motivados pela seca e salinização das águas apoiados pela SUDENE (Superintendência do Desenvolvimento do Nordeste) e inicialmente tinham como objetivos o conhecimento da origem e dos mecanismos de recarga dos aquíferos, a causa da salinização, o tempo de trânsito e a datação (SILVEIRA \& SILVA JUNIOR, 2002).

No vale da estabilidade (zona onde os isótopos estáveis se localizam no gráfico $\mathrm{Z}$ x N), os isótopos mais leves $(\mathrm{N}<20)$ possuem relação linear entre o número de prótons e nêutrons. A partir de $\mathrm{N}>20$ os mesmos tendem a ter um excesso de nêutrons. Outra curiosidade é que os elementos que possuem número atômico $(Z)$ par possuem maior número de isótopos do que os que possuem $Z$ ímpar (ALLÈGRE, 2008). Normalmente, para um mesmo elemento químico, os isótopos com menor massa atômica (denominados isótopos leves) são mais abundantes que os isótopos com maior valor de A (denominados isótopos pesados). A Tabela 3.1 mostra a abundância média dos isótopos estáveis mais utilizados em estudos ambientais. 
Tabela 3.1 - Isótopos estáveis dos principais elementos utilizados como traçadores ambientais e suas respectivas abundâncias (Adaptado de MARTINELLI et al., 2009).

\begin{tabular}{|c|c|c|}
\hline Elemento & Isótopos & A bundância média \\
\hline \multirow{2}{*}{ Carbono } & ${ }^{12} \mathrm{C}$ & 98,89 \\
\cline { 2 - 3 } & ${ }^{13} \mathrm{C}$ & 1,11 \\
\hline \multirow{2}{*}{ Nitrogênio } & ${ }^{14} \mathrm{~N}$ & 99,34 \\
\cline { 2 - 3 } Oxigênio & ${ }^{15} \mathrm{~N}$ & 0,37 \\
\hline \multirow{3}{*}{ Hidrogênio } & ${ }^{16} \mathrm{O}$ & 99,76 \\
\cline { 2 - 3 } & ${ }^{17} \mathrm{O}$ & 0,037 \\
\hline \multirow{3}{*}{ Enxofre } & ${ }^{18} \mathrm{O}$ & 0,199 \\
\cline { 2 - 3 } & ${ }^{1} \mathrm{H}$ & 98,98 \\
\cline { 2 - 3 } & ${ }^{2} \mathrm{H}(\mathrm{D})$ & 0,02 \\
\cline { 2 - 3 } & ${ }^{32} \mathrm{~S}$ & 95,00 \\
\cline { 2 - 3 } & ${ }^{33} \mathrm{~S}$ & 0,76 \\
\hline \multirow{4}{*}{ Estrôncio } & ${ }^{36} \mathrm{~S}$ & 4,22 \\
\cline { 2 - 3 } & ${ }^{84} \mathrm{Sr}$ & 0,01 \\
\cline { 2 - 3 } & ${ }^{86} \mathrm{Sr}$ & 0,56 \\
\cline { 2 - 3 } & ${ }^{87} \mathrm{Sr}$ & 9,86 \\
\hline
\end{tabular}

O uso de isótopos estáveis em estudos ambientais se baseia no fato de que a composição isotópica varia de forma previsível, conforme o elemento se move através dos diversos compartimentos de um sistema. Fracionamento isotópico é a variação na proporção entre os isótopos estáveis em um determinado composto ao passar por um processo físico-químico. E ocorre devido a pequenas diferenças nas características químicas e físicas dos isótopos. A diferença de massa entre os isótopos não causa mudanças na sua reatividade química, mas sim em suas velocidades de reação. Os isótopos pesados possuem vibrações mais lentas e consequentemente velocidade de reação mais demorada. Dessa forma, em um sistema as moléculas formadas por isótopos leves possuem maior frequência de choque com outras moléculas e maior velocidade de reação (MARTINELLI et al., 2009).

Alguns conceitos são importantes nos estudos ambientais utilizando isótopos estáveis. A composição isotópica ou razão isotópica $(\mathrm{R})$ é a relação entre o isótopo raro (pesado) e o abundante (leve) e pode ser definido como (MOOK, 2001):

$$
R=\frac{\text { Abundância do isótopo raro }}{\text { Abundância do isótopo abundante }}
$$

Por exemplo: $R_{\text {oxigênio }}=\frac{O^{18}}{O^{16}} R_{\text {carbono }}=\frac{C^{13}}{C^{12}}$

$\mathrm{O}$ cálculo de $\mathrm{R}$ se refere ao número de átomos e não a massa correspondente a cada isótopo na amostra (ALLÈGRE, 2008). Este representa a relação direta entre o isótopo raro e abundante. Assim, quando o $\mathrm{R}$ é maior que 1 o sistema está enriquecido em isótopos raros (pesados) e quando $\mathrm{R}$ é menor que 1 o sistema está enriquecido em isótopos abundantes (leves).

A descrição matemática do processo de fracionamento é feita pela comparação da composição isotópica de 2 componentes em equilíbrio $(A \leftrightarrow B)$ ou de 2 componentes antes e depois de um processo de transição químico ou físico $(A \rightarrow B)$. Dessa forma se definiu o Fator de Fracionamento $(\alpha)$ como (MOOK, 2001):

$$
\alpha_{A}(B)=\alpha_{B / A}=\frac{R_{B}}{R_{A}}
$$


No fracionamento isotópico de equilíbrio, $\alpha$ representa a constante de equilíbrio da uma reação e geralmente possui valor próximo da unidade, por conta disso definiu-se o Fator de Enriquecimento Isotópico $(\varepsilon)$ ou Discriminação Isotópica $(\Delta)$ que é representado por (MARTINELLI et al., 2009):

$$
\Delta=(\alpha-1) \quad \text { ou } \quad \Delta=\frac{\delta_{A}-\delta_{B}}{\delta_{B}+1.000}
$$

Diferentemente do $\alpha, \Delta$ não implica em uma situação de equilíbrio. $\Delta$ representa o enriquecimento $(\Delta>0)$ ou o empobrecimento $(\Delta<0)$ do isótopo pesado na situação B em relação à situação A (MOOK, 2001).

Interpretar a composição isotópica absoluta de uma amostra é complexo. Em função disso, propôs-se representá-la por seu desvio em relação a um padrão. Assim, a notação $\delta$ denota a ocorrência natural de uma espécie isotópica em relação ao padrão. $\delta$ é assim definido (MARTINELLI et al., 2009):

$$
\delta=\frac{R_{\text {amostra }}-R_{\text {padrão }}}{R_{\text {padrão }}} \times 1.000
$$

$\delta$ é representado em partes por mil (\%). Observando a equação podemos deduzir que

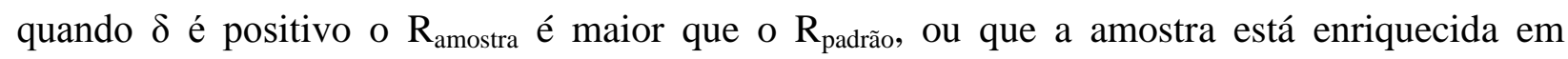
isótopos pesados (raros) em relação ao padrão. Já quando $\delta$ é negativo $\mathrm{R}_{\text {amostra }}$ é menor que o

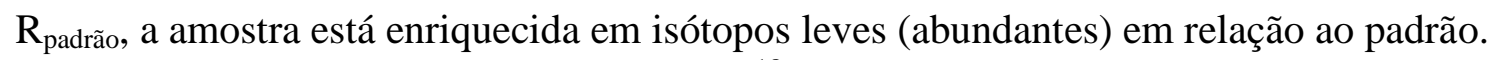

Existem 2 padrões clássicos para o ${ }^{18} \mathrm{O}$ e o D que são SMOW e VSMOW. Ambos são provenientes da água dos oceanos. Em 1953, Epstein e Mayeda coletaram amostra de todos os oceanos e com esses resultados foi criada a amostra padrão do SMOW (Standard Mean Ocean Water). Em 1976, a seção de hidrologia isotópica da IAEA (International Atomic Energy Agency) e a NIST (US National Institute of Standards and Technology) criaram uma amostra padrão para ser distribuída ao redor do mundo do SMOW, em Viena, Áustria. Esse material foi criado por H. Craig para equalizar o antigo SMOW para $\delta^{18} \mathrm{O}$ e $\delta \mathrm{D}$ e foi denominado VSMOW. Análises em laboratório mostraram que a diferença entre eles é muito pequena (aproximadamente $+0,05 \%$ ). Por definição: $\delta^{18} \mathrm{O}_{\mathrm{VSMOW}}=0 \%$ e $\delta \mathrm{D}_{\mathrm{VSMOW}}=0 \%$ (MOOK, 2001).

$\mathrm{O}$ oceano é o maior reservatório de água do planeta. A abundância de ${ }^{18} \mathrm{O}$ e $\mathrm{D}$ na sua camada superficial tende a ser uniforme (variando de $+0,5$ a $-0,5 \%$ ). Somente quando comparamos os valores da região tropical e polar é que variações mais expressivas são observadas. Nas regiões tropicais valores mais positivos de $\delta^{18} \mathrm{O}$ e de $\delta \mathrm{D}$ são observados devido a maior taxa de evaporação, enquanto que nas regiões polares valores mais negativos são encontrados devido à contribuição da neve e dos gelos das geleiras que são mais negativas (MOOK, 2001).

Os principais padrões definidos estão representados na Tabela 3.2.

\begin{tabular}{|c|c|c|c|c|}
\hline Nome do padrão & Elementos & $\mathbf{R}$ & Origem & $\delta$ \\
\hline \multirow{2}{*}{$\begin{array}{l}\text { Pee Dee Belemnite } \\
\text { (PDB) }\end{array}$} & Carbono & 0,0112372 & \multirow{2}{*}{$\begin{array}{c}\text { Carbonato de Belemnite (grupo } \\
\text { de moluscos marinhos) } \\
\text { encontrado na Formação Pee } \\
\text { Dee na América do Norte }\end{array}$} & $\delta^{13} \mathrm{C}_{\mathrm{PDB}}$ \\
\hline & Oxigênio & 0,0020672 & & $\delta^{18} \mathrm{O}_{\mathrm{PDB}}$ \\
\hline Nitrogênio atmosférico & Nitrogênio & 0,0036765 & Atmosfera & $\delta^{15} \mathrm{~N}_{\mathrm{AIR}}$ \\
\hline \multirow{2}{*}{$\begin{array}{c}\text { SMOW (Standard Mean } \\
\text { Ocean Water) }\end{array}$} & Oxigênio & 0,00200052 & Água do mar & $\delta^{18} \mathrm{O}_{\text {SMOW }}$ \\
\hline & Hidrogênio & 0,00015576 & Água do mar & $\delta \mathrm{D}_{\text {SMOW }}$ \\
\hline \multirow{2}{*}{ SMOW Viena } & Oxigênio & 0,0020052 & Água do mar & $\delta^{18} \mathrm{O}_{\text {VSMOW }}$ \\
\hline & Hidrogênio & 0,00015560 & Água do mar & $\delta \mathrm{D}_{\text {VSMOW }}$ \\
\hline $\begin{array}{l}\text { CDT (Canyon Diablo } \\
\text { Troilite) }\end{array}$ & Enxofre & 0,0451509 & $\begin{array}{c}\text { Troilita do meteorito Cañon } \\
\text { Diablo }\end{array}$ & $\delta^{34} \mathrm{~S}_{\text {TROILITA }}$ \\
\hline
\end{tabular}

Tabela 3.2 - Principais padrões dos isótopos estáveis mais utilizados em estudos ambientais. 
$\delta$ e $\alpha$ possuem relação que pode ser expressa pela equação:

$$
1.000 \times \ln \alpha_{A-B}=\delta_{A}-\delta_{B}
$$

A diferença de velocidade entre os isótopos pesados e leves é denominada efeito isotópico cinético e é um dos mecanismos de fracionamento. Segundo definição, para gases ideais, moléculas e átomos iguais possuem mesma energia cinética que é representada pela fórmula:

$$
E c=\frac{m \cdot v^{2}}{2}
$$

Onde Ec é a energia cinética, m é a massa atômica ou molecular e v é a velocidade média do átomo ou da molécula. Dessa forma, para um isótopo leve e pesado (que possuem mesma Ec) quanto maior a massa menor a velocidade do isótopo ou da molécula que contém o isótopo. $\mathrm{O}$ efeito isotópico cinético ocorre em processos físicos e químicos irreversíveis devido à diferença de velocidade e de energia de ligação entre os isótopos leves e pesados (MOOK, 2001).

Outro mecanismo de fracionamento é denominado efeito isotópico termodinâmico ou de equilíbrio e tem como princípio básico a diferença de energia de ligação entre os isótopos pesados e leves. Os primeiros possuem energia de ligação mais forte que os segundos sendo que é necessária mais energia para quebrar as moléculas formadas por eles. Esse efeito é dependente da temperatura, pois quanto maior a temperatura menor é a diferença entre as energias de ligação e consequentemente menor é o fracionamento isotópico. Ele ocorre em reações de equilíbrio (como as reações de equilíbrio termodinâmico), onde há a troca entre partículas de 2 sistemas que atingem ao final o equilíbrio isotópico (MOOK, 2001).

Mook (2001) relata o fenômeno chamado Efeito Isotópico Inverso que ocorre em certas condições com moléculas poli atômicas em que a energia potencial é maior para as moléculas com isótopos leves do que para as com isótopos pesados. Devido a esse fenômeno a energia de ligação da molécula com isótopo pesado pode ser menor do que a com isótopo leve causando efeitos opostos em alguns fracionamentos (Figura 3.9) (MOOK, 2001).

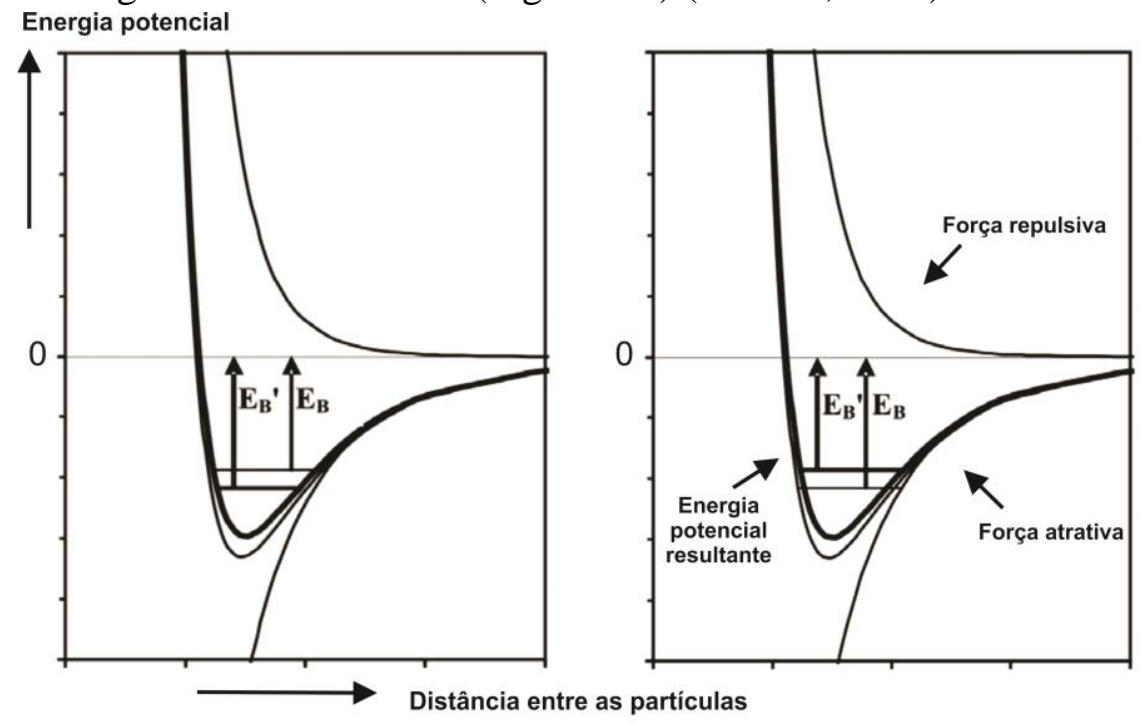

\section{Efeito Isotópico Normal}

\section{Efeito Isotópico Inverso}

Figura 3.9 - Representação esquemática da distribuição da energia potencial causada por forças repulsivas e atrativas entre 2 partículas de cargas opostas no efeito isotópico cinético normal e inverso. Onde uma partícula está localizada no 0 e a outra na linha de energia potencial resultante. As linhas horizontais representam o nível de energia do sistema, sendo que a linha fina se refere ao isótopo leve e a grossa ao isótopo pesado. $E_{B}$ e $E_{B}$ ' representam a energia de ligação do isótopo leve e pesado respectivamente (Adaptado de MOOK, 2001). 
O fracionamento isotópico possui relação direta com a temperatura, sendo que conforme a temperatura aumenta $\alpha$ tende a 1 e $\delta$ tende a 0 . Ou seja, é um processo restrito a baixas temperaturas. Em contraposição a isso, as variações de volume são praticamente nulas. Indicando que variações de pressão são insignificantes nesse processo. Portanto, o fracionamento isotópico é um bom geotermômetro.

Os estudos ambientais se concentram em elementos químicos com baixo número atômico como: carbono, nitrogênio, hidrogênio e oxigênio. A diferença de massa entre os isótopos estáveis de elementos com baixo número atômico é mais significativa do que em elementos com número atômico muito alto como estrôncio ou urânio (a presença ou ausência de 1 ou 2 nêutrons não interfere tanto no total de suas massas). Além disso, os primeiros costumam fazer ligações covalentes ao formar moléculas, enquanto que os elementos de alto $\mathrm{Z}$ costumam fazer ligações iônicas. O fracionamento isotópico ocorre de maneira mais eficiente em isótopos com diferenças de massa mais significativas e em moléculas formadas por ligações covalentes. Isso se deve ao fato de que no compartilhamento dos elétrons na ligação covalente ocorrem vibrações que permitem que a diferença de velocidade entre as moléculas com isótopos leves e pesados interfiram de maneira mais significativa.

De acordo com a química clássica, as características químicas e físicas de um elemento não variam. Isso é verdade em grandes escalas e em estudos genéricos. Porém, se a medição tiver uma acurácia suficiente (como é o caso dos espectrômetros de massa modernos) as diferenças de massa dos isótopos ocasionam uma discreta mudança nas características físicas e química do elemento. O que gera uma alteração discreta das propriedades físicas e químicas das moléculas

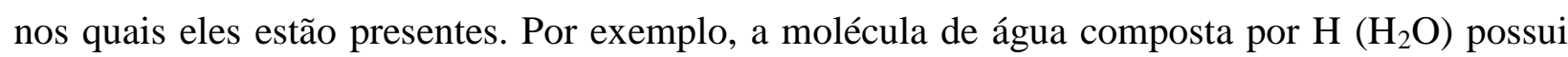
ponto de ebulição de $100^{\circ} \mathrm{C}$, já a composta por $\mathrm{D}\left(\mathrm{D}_{2} \mathrm{O}\right)$ sofre ebulição a $101,42^{\circ} \mathrm{C}$. Mudanças também são observadas no ponto de fusão, pressão de vapor, viscosidade e densidade (MOOK, 2001).

$\mathrm{Na}$ presente dissertação os estudos irão se concentrar nos isótopos de oxigênio e hidrogênio.

$\mathrm{O}$ oxigênio possui 3 isótopos estáveis, são eles: ${ }^{16} \mathrm{O},{ }^{17} \mathrm{O},{ }^{18} \mathrm{O}$. Suas respectivas abundâncias estão na Tabela 3.1. A abundância do ${ }^{17} \mathrm{O}$ fornece menos informações a respeito do ciclo hidrológico, em seu sensu strictu, comparativamente ao ${ }^{18} \mathrm{O}$ mais abundante. Assim, os estudos hidrológicos se concentram na razão ${ }^{18} \mathrm{O} /{ }^{16} \mathrm{O}$. A Figura 3.10 mostra as variações do $\delta^{18} \mathrm{O}$ em compostos naturais e nos principais componentes do ciclo hidrológico (MOOK, 2001).

$\mathrm{O}$ hidrogênio possui 2 isótopos estáveis, são eles: ${ }^{1} \mathrm{H} \mathrm{e}{ }^{2} \mathrm{H}$ (Deutério). A variação do $\delta \mathrm{D}$ em ambiente natural é por volta de $250 \%$, valor bem superior ao encontrado para $\delta^{18} \mathrm{O}$ e $\delta^{13} \mathrm{C}$ (cerca de $100 \%$ ). Isso se deve a grande diferença de massa entre os 2 isótopos (D possui o dobro da massa do $\mathrm{H}$ ). A Figura 3.11 mostra as variações de $\delta \mathrm{D}$ nos compostos naturais e nos principais componentes do ciclo hidrológico (MOOK, 2001).

$\mathrm{O}{ }^{18} \mathrm{O}$ e o D presentes na água sofrem fracionamento isotópico durante a evaporação e a condensação e com isso a água adquire uma assinatura isotópica individual e característica. Quando ocorre evaporação o ${ }^{16} \mathrm{O}$ e o ${ }^{1} \mathrm{H}$ tendem a se concentrar na fase gasosa enquanto que o ${ }^{18} \mathrm{O}$ e o D se concentram na fase líquida. Sendo assim, lagos com altas taxas de evaporação costumam ser enriquecidos em ${ }^{18} \mathrm{O}$ e $\mathrm{D}$ enquanto que o vapor de água das nuvens tende a ser empobrecidos em ${ }^{18} \mathrm{O}$ e D. Variações sistemáticas nos isótopos em diferentes etapas do ciclo das águas são utilizados para traçar a origem e a dinâmica da água pelo ciclo hidrológico (MOOK, 2001). 
Comparado ao oceano $\left(\delta^{18} \mathrm{O}_{\mathrm{VSMOW}}=0 \%\right.$ e $\delta \mathrm{D}_{\mathrm{VSMOW}}=0 \%$ ) as águas meteóricas são empobrecidas em isótopos pesados e possuem valores negativos de delta. A principal razão disso é que a maior parte delas é derivada da evaporação do oceano. $\mathrm{O}$ valor médio de $\delta^{18} \mathrm{O}$ de todas as águas da hidrosfera pode ser estimado em -0,64\%o, das acumulações de gelo -30 \%o e da água subterrânea em -7\%o. Nos períodos de glaciação os valores de $\delta^{18} \mathrm{O}$ podem chegar a $+1 \%$ devido ao desequilíbrio entre evaporação/condensação (GAT et al., 2001).

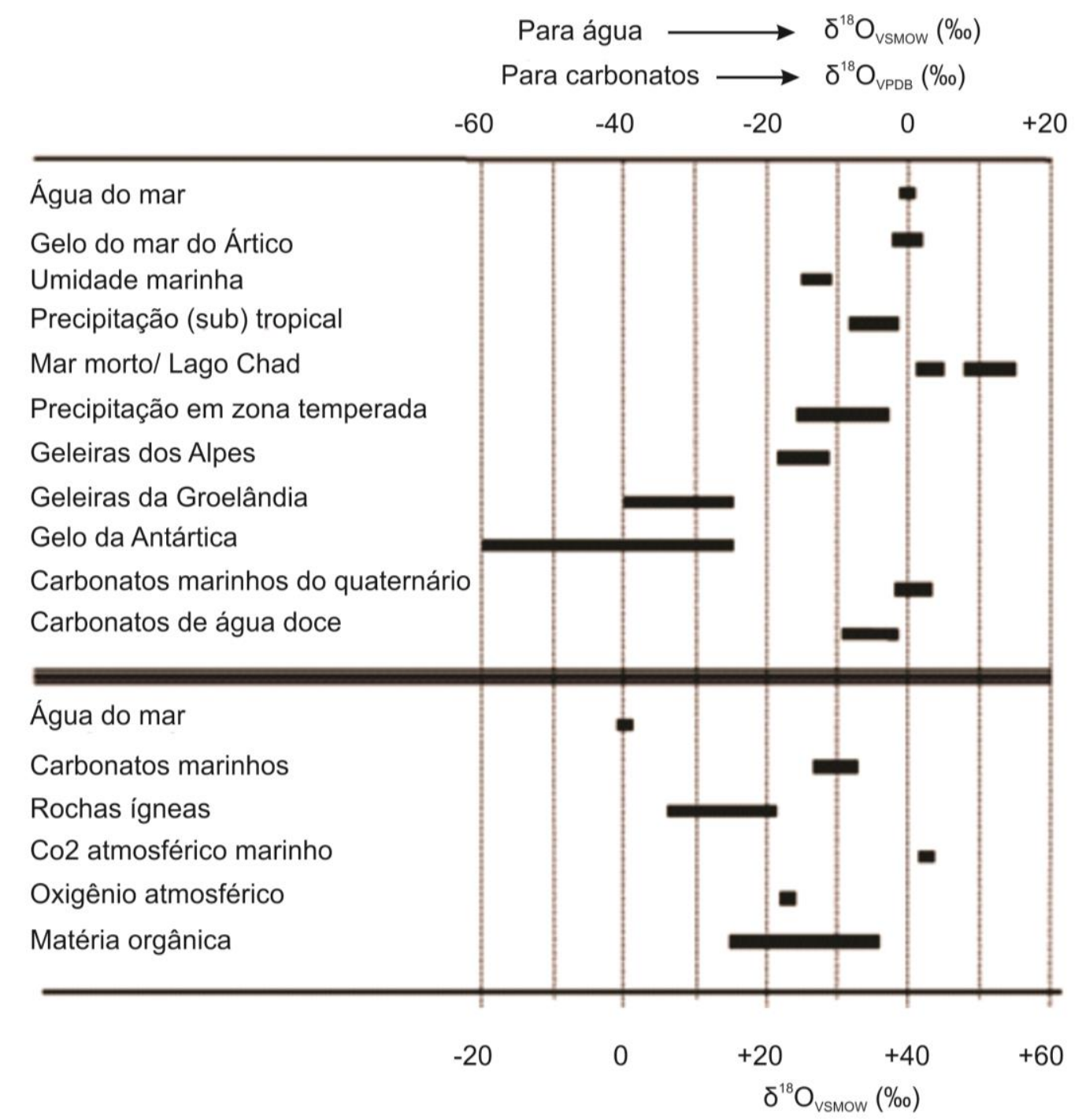

Figura 3.10 - Variações do $\delta^{18} \mathrm{O}_{\text {vsmow }}(\%)$ em compostos naturais (Adaptado de MOOK, 2001). 


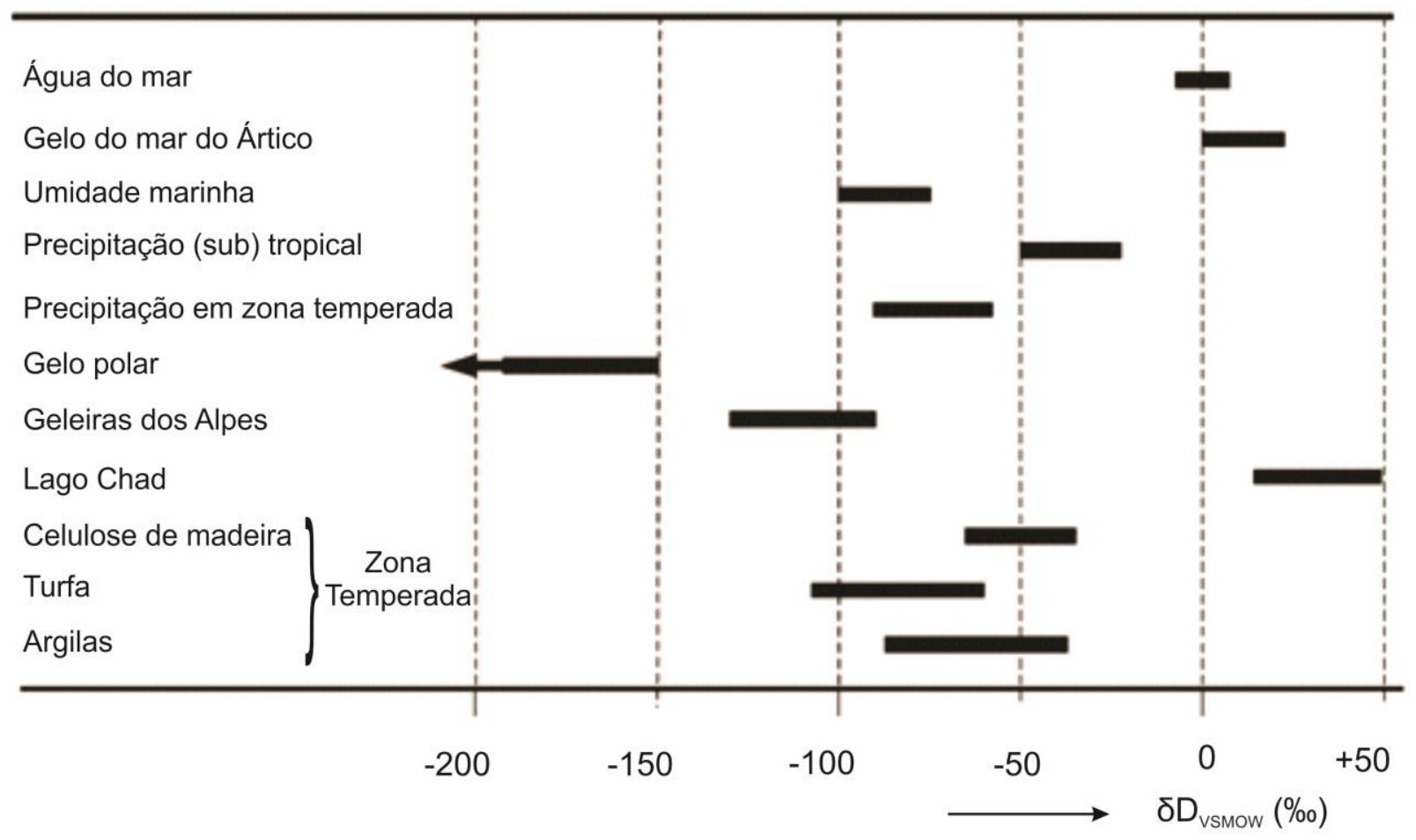

Figura 3.11 - Variações do $\delta D_{\text {vsmow }}$ em ambientes naturais (Adaptado de MOOK, 2001).

Existem 2 processos principais no ciclo das águas que são a base para o entendimento das variações de $\delta^{18} \mathrm{O}$ e $\delta \mathrm{D}$ : A evaporação na superfície dos oceanos e a progressiva precipitação conforme as massas de ar se movem para regiões de baixas temperaturas (altas latitudes e altitudes) (GAT et al., 2001).

As nuvens durante sua trajetória sofrem variação isotópica. Esse fenômeno é conhecido como fracionamento Rayleigh e consiste no empobrecimento em isótopos pesados de uma massa de ar por fracionamento em estado de equilíbrio para uma fase continuamente removida. Quando há a condensação do vapor de água na formação da chuva, os isótopos pesados tendem a se concentrar nas gotas de chuva deixando a nuvem com $\delta$ cada vez mais negativo (Figura 3.12) (MARTINELLI et al., 2009).

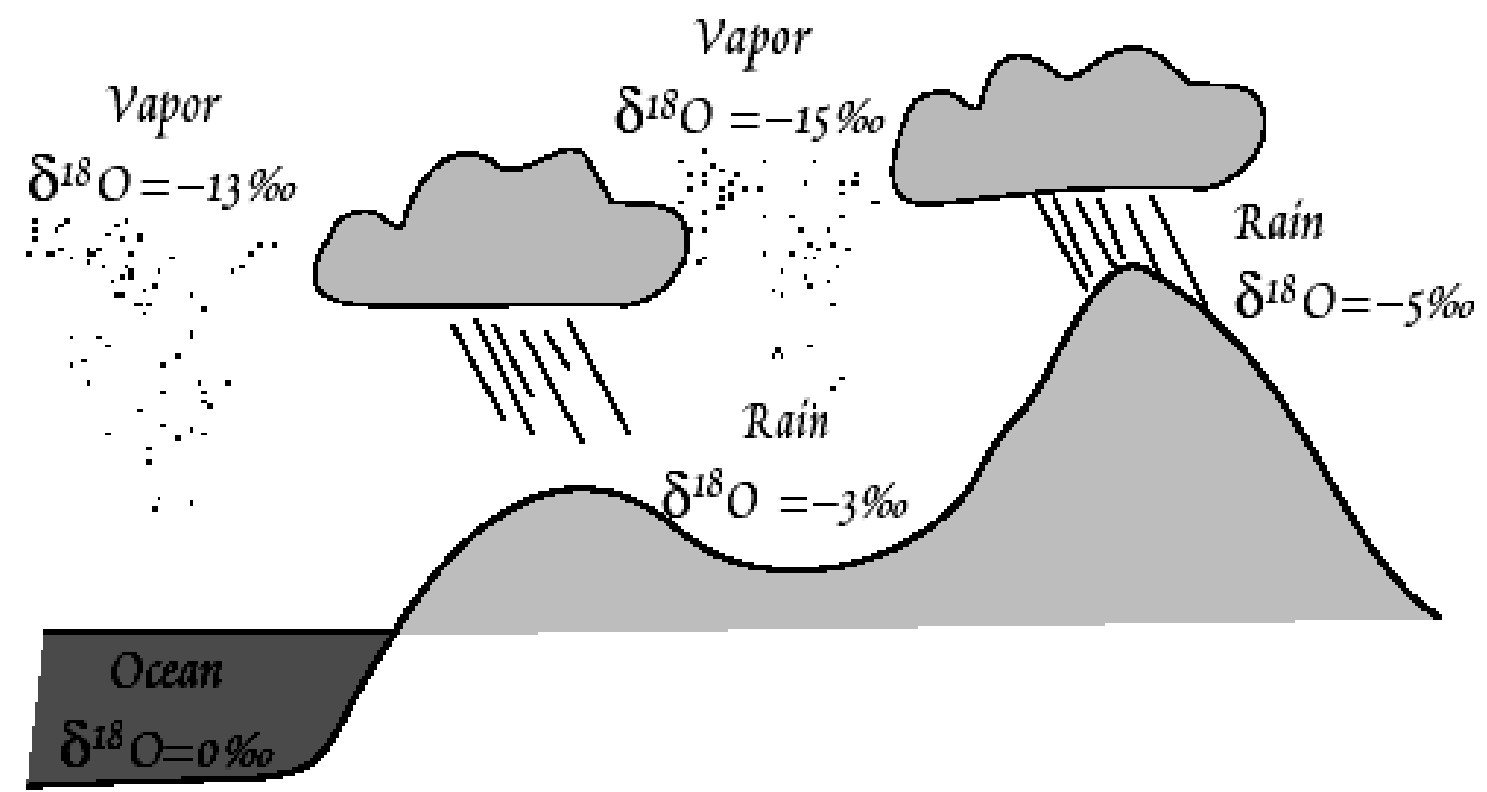

Figura 3.12 - Esquema simplificado do fracionamento Rayleigh. 
$\mathrm{O} \delta^{18} \mathrm{O}$ e o $\delta \mathrm{D}$ das precipitações dependem do clima e de fatores locais, dessa forma possuem grandes variações ao redor do globo. O tamanho das gotas e até a nuvem onde a gota foi formada alteram suas assinaturas isotópicas. Os efeitos que causam essa grande amplitude de valores nas precipitações serão discriminados a seguir (GAT et al., 2001):

- Efeito da latitude: a grande fonte de formação de vapor de água para a atmosfera é a evaporação dos oceanos na região tropical (onde a superfície do mar é mais quente). $\mathrm{O}$ vapor de água é carregado para as maiores latitudes pelas grandes massas de ar e durante esse percurso progressivas condensações ocorrem. Assim, em geral as chuvas nas baixas latitudes (próximo à fonte do vapor de água) tendem a serem menos negativas do que as chuvas de altas latitudes (longe da fonte de vapor de água). Além disso, o fracionamento isotópico é mais intenso em menores temperaturas. Por esses motivos o $\delta^{18} \mathrm{O}$ de geleiras na Antártica pode chegar a -50 \%o (Figura 3.13);

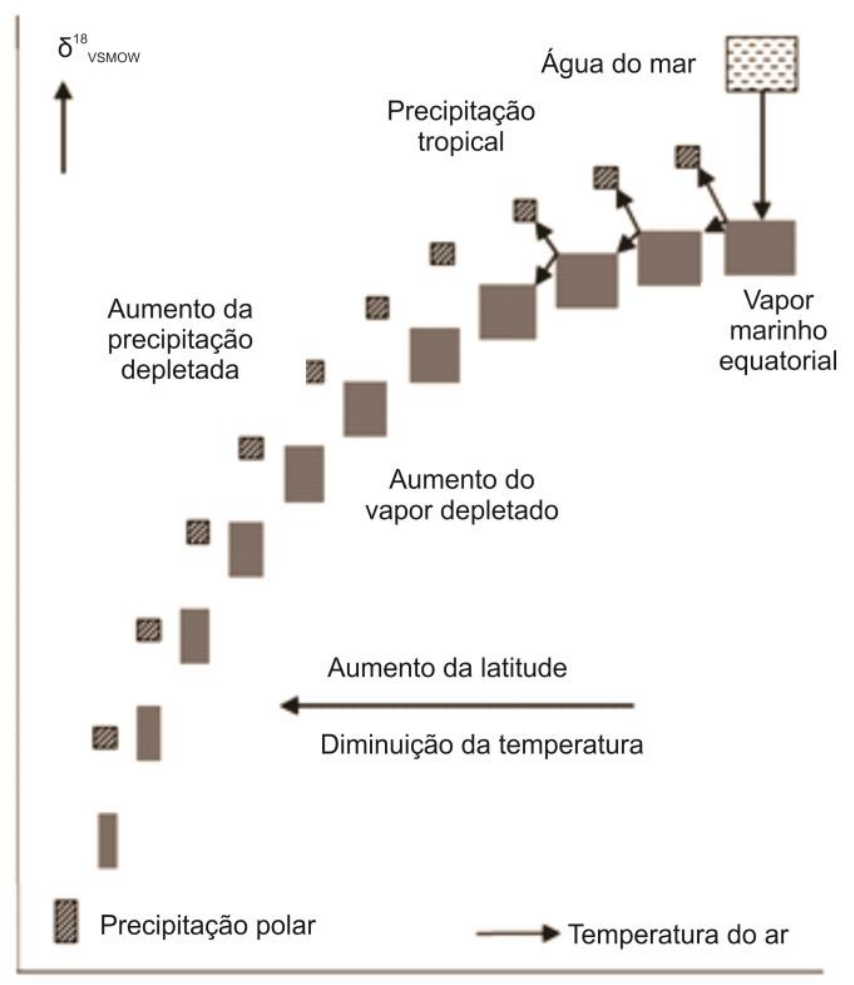

Figura 3.13 - Representação esquemática do empobrecimento de ${ }^{18} \mathrm{O}$ do vapor atmosférico e da precipitação conforme o vapor de água se distancia da principal fonte (região tropical) (Adaptado de GAT et al., 2001).

- Efeito da continentalidade: as chuvas tendem a ser mais negativas quanto mais distantes dos oceanos. Isso ocorre devido ao fracionamento Rayleigh já explicitado anteriormente. Varia consideravelmente de área para área e de estação pra estação e é relacionada ao gradiente de temperatura, a topografia e ao regime climático da área;

- Efeito da altitude: quanto maior a altitude, mais negativa tende a ser a chuva. Isso ocorre devido à diferença de temperatura. Em altas altitudes a temperatura tende a ser menor o que torna mais eficiente o fracionamento isotópico. Em altas altitudes o nível de base das nuvens tende a ser mais alto o que leva a um enriquecimento em isótopos pesados nas gotas de chuva durante suas quedas devido às chuvas ocorrerem abaixo do nível de base das nuvens;

- Efeito da sazonalidade: valores mais negativos de $\delta^{18} \mathrm{O}$ e $\delta \mathrm{D}$ são encontrados no inverno comparado com o verão. Isso ocorre também, devido à diferença de temperatura. Tende a 
ser mais brando do que o efeito da latitude e é mais expressivo nas regiões temperadas onde as diferenças de temperatura entre o inverno e o verão são mais significativas. Nas regiões tropicais a fonte do vapor de água é próxima a região da precipitação o que faz a dependência da temperatura quase desaparecer;

- Efeito da quantidade: durante o processo de condensação, o vapor de água remanescente fica progressivamente empobrecido em isótopos pesados. Dessa forma, no início as chuvas tendem a ser mais pesadas do que no final. E no geral, chuvas menos intensas (chuviscos e chuvas fracas) são mais pesadas apresentando valores mais elevados de $\delta^{18} \mathrm{O}$ e $\delta \mathrm{D}$ em comparação com chuvas fortes (SANTIAGO et al., 2008). O comportamento do fracionamento isotópico em relação a intensidade das chuvas não é generalista, sendo que esse efeito deve ser analisado em cada caso individualmente.

Os isótopos estáveis são traçadores da origem e formação das águas subterrâneas e possuem aplicações em diversas áreas da hidrogeologia, como: interação da água subterrânea com água superficial, mistura de águas de aquíferos distintos, fluxo, tempo de residência, água subterrânea fóssil, poluição, fluidos geotermais, recarga, entre outros. São utilizados como traçadores de movimento das águas subterrâneas, das condições climáticas, dos processos geoquímicos e hidrológicos e da dinâmica de processos hidrológicos. Por exemplo: em aquíferos que a recarga é predominantemente por rios os valores de delta costumam ser mais negativos, e onde a recarga é predominantemente por lagos e reservatórios, mais positivas (ARAGUÁS, 2014).

As rochas ígneas, metamórficas e os carbonatos são enriquecidos em isótopos pesados e possuem valores positivos de $\delta^{18} \mathrm{O}$ e de $\delta \mathrm{D}$ (ALLÈGRE, 2008).

Martinelli et al. (2009) e Araguás (2014) relatam um modelo de mistura de duas fontes (diluição isotópica). Quando 2 fontes com assinaturas isotópicas distintas se misturam para gerar um produto, a contribuição relativa de cada uma delas pode ser calculada através desse modelo. O modelo consiste de uma combinação do balanço de massa com o balanço isotópico. Tomando como base a mistura:

$$
P=A+B
$$

A fórmula que calcula a contribuição de casa fase da mistura leva em consideração o $\delta$ das fases da mistura e do produto.

$$
Q_{P} \cdot \delta_{P}=Q_{A} \cdot \delta_{A}+Q_{B} \cdot \delta_{B}
$$

Onde $\mathrm{Q}_{\mathrm{A}}, \mathrm{Q}_{\mathrm{B}}, \mathrm{Q}_{\mathrm{P}}$ representam as contribuições relativas das fases $\mathrm{A}$ e $\mathrm{B}$ e do produto, respectivamente. $\mathrm{O}$ modelo requer que somente 2 fases estejam presentes e que as mesmas difiram isotopicamente o suficiente para que possam ser medidas acima do erro inerente à análise (MARTINELLI et al., 2009).

Com base em estudos feitos por Craig em 1961 com isótopos estáveis em águas de chuva, foi observado que existe uma correlação entre o fracionamento do D e do ${ }^{18} \mathrm{O}$. Sendo assim, uma relação entre o $\delta^{18} \mathrm{O}$ e $\delta \mathrm{D}$ é esperada em águas naturais. A relação é determinada tanto pelo fracionamento de equilíbrio vapor/líquido quanto pelo líquido/vapor. Se nós assumirmos que a evaporação e a condensação na natureza ocorrem sobre equilíbrio isotópico. Assim sendo, Craig e Dansgaard encontraram uma relação entre o $\delta^{18} \mathrm{O}$ e $\delta \mathrm{D}$ de amostras de chuva de várias partes do mundo. Essa relação ficou conhecida como a Curva Global da Água Meteórica (em inglês GMWL-Global Meteoric Water Line) e é expressa pela equação (GAT et al., 2001; SANTIAGO et al., 2008): 


$$
\delta \mathrm{D}=8 . \delta O^{18}+10
$$

A inclinação da curva (8) foi determinada em função das razões isotópicas no fracionamento de equilíbrio do hidrogênio e do oxigênio entre a água e o vapor d'água em aproximadamente $20{ }^{\circ} \mathrm{C}$ (Figura 3.14). A intercessão com o eixo y (10) se refere ao excesso de hidrogênio (excesso de deutério) (GAT et al., 2001; ALLÈGRE, 2008).

\begin{tabular}{c|ccc}
$\mathbf{t}$ & ${ }^{2} \boldsymbol{\varepsilon}_{\mathrm{v} / \mathbf{1}}$ & ${ }^{\mathbf{1 8}} \boldsymbol{\varepsilon}_{\mathrm{v} / \mathbf{l}}$ & ${ }^{2} \varepsilon_{\mathrm{v} /} /{ }^{\mathbf{1 8}} \boldsymbol{\varepsilon}_{\mathrm{v} / \mathbf{l}}$ \\
$\mathbf{( { } ^ { \circ } \mathbf { C } )}$ & $\mathbf{( \% \mathbf { 0 } )}$ & $\mathbf{( \% \mathbf { 0 }}$ & \\
\hline $\mathbf{0}$ & -101.0 & -11.55 & 8.7 \\
$\mathbf{5}$ & -94.8 & -11.07 & $8.5^{5}$ \\
$\mathbf{1 0}$ & -89.0 & -10.60 & 8.4 \\
$\mathbf{1 5}$ & -83.5 & -10.15 & $8.2^{5}$ \\
$\mathbf{2 0}$ & -78.4 & -9.71 & 8.1 \\
$\mathbf{2 5}$ & -73.5 & -9.29 & 7.9 \\
$\mathbf{3 0}$ & -68.9 & -8.89 & $7.7^{5}$ \\
$\mathbf{3 5}$ & -64.6 & -8.49 & 7.6 \\
$\mathbf{4 0}$ & -60.6 & -8.11 & 7.4
\end{tabular}

Figura 3.14 - Fator de Enriquecimento Isotópico (E) ou Discriminação Isotópica $(\Delta)$ em função da temperatura para um sistema em equilíbrio entre a evaporação e a condensação. $O$ valor a $20^{\circ} \mathrm{C}$ corresponde à inclinação da curva da água meteórica (GAT et al., 2001).

Existem variações da curva da água meteórica que indicam processos de trocas isotópicas e fracionamento isotópico (Figura 3.15). Por exemplo, evaporação em águas salobras de aquíferos sedimentares costeiros, troca de isótopos de oxigênio entre moléculas de água e silicatos em sistemas geotermais, mistura de água subterrânea recentes com águas fósseis em rochas cristalinas. $O$ excesso de hidrogênio próximo a costa tende a ser menor que 10 , na Antártica ele fica próximo a 0 e onde a umidade relativa logo acima dos oceanos é ou foi menor que o valor médio atual o valor de d é maior que 10. Por exemplo, na leste do mediterrâneo esse valor é +22\%o (GAT et al., 2001; GEYH, 2001).

O fenômeno denominado excesso de deutério, indicado na Figura 3.16, ocorre em regiões áridas e semiáridas onde há evaporação durante a queda da chuva. Isso faz com que as águas residuais fiquem enriquecidas em isótopos pesados $(\delta>0)$ e se desloquem para a direita da GMWL. A inclinação da curva fica com valor menor que 8 . O excesso de deutério durante a evaporação depende da umidade relativa e da velocidade do vento (ARAGUÁS, 2014; SANTIAGO et al., 2008).

O fracionamento isotópico entre a água e os minerais geralmente são irreversíveis e o fracionamento é cinético. Devido à diminuta velocidade de troca isotópica em baixa temperatura entre água-rocha, a água subterrânea dificilmente atinge o equilíbrio isotópico com as rochas do aquífero e tende a preservar sua composição isotópica por um período prolongado de tempo. Porém, exceções existem e já foram retratados na literatura. A reação entre o $\mathrm{CO}_{2}$ e a calcita e a oxidação de material orgânico, como turfa, e processos de metabolismo microbiológico podem alterar a composição isotópica das águas e das rochas dos aquíferos (GEYH, 2001). 


\section{Sistema de baixa temperatura}

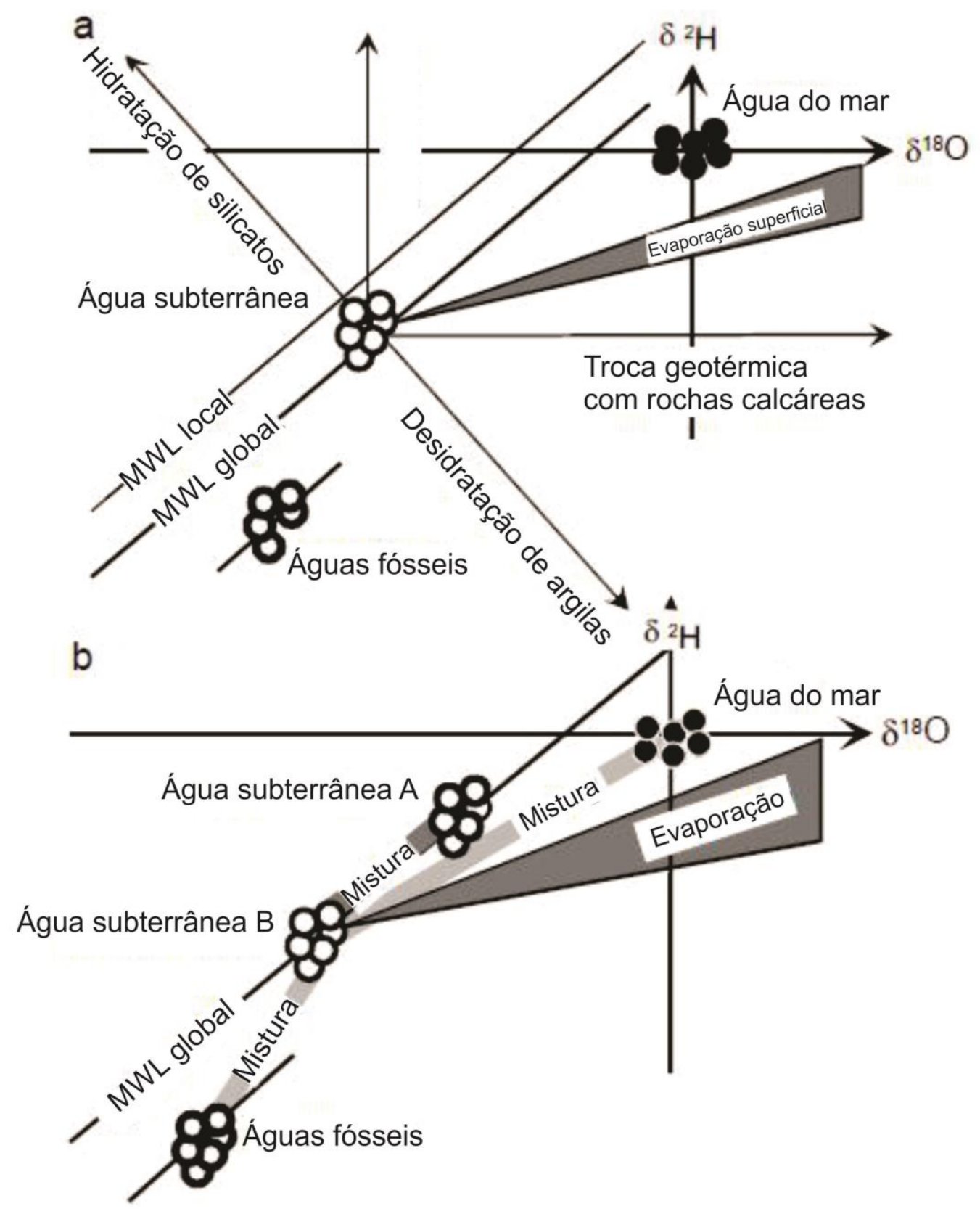

Figura 3.15 - Exemplos de processos que alteram a curva global da água meteórica (Adaptado de GEYH, 2001).

Para a escala global a relação entre $\delta^{18} \mathrm{O}$ e $\delta \mathrm{D}$ pode ser satisfatoriamente descrita pela GMWL, já localmente a curva da água meteórica local (LMWL - Local Meteoric Water Line) representa melhor as condições de fontes de água meteórica de cada região (GAT et al., 2001). Segundo Silveira \& Silva Junior (2002), a reta da água meteórica local para a região nordeste, obtida com várias estações meteorológicas da área é:

$$
\delta D=10( \pm 2)+8,2( \pm 0,8) \delta^{18} O
$$




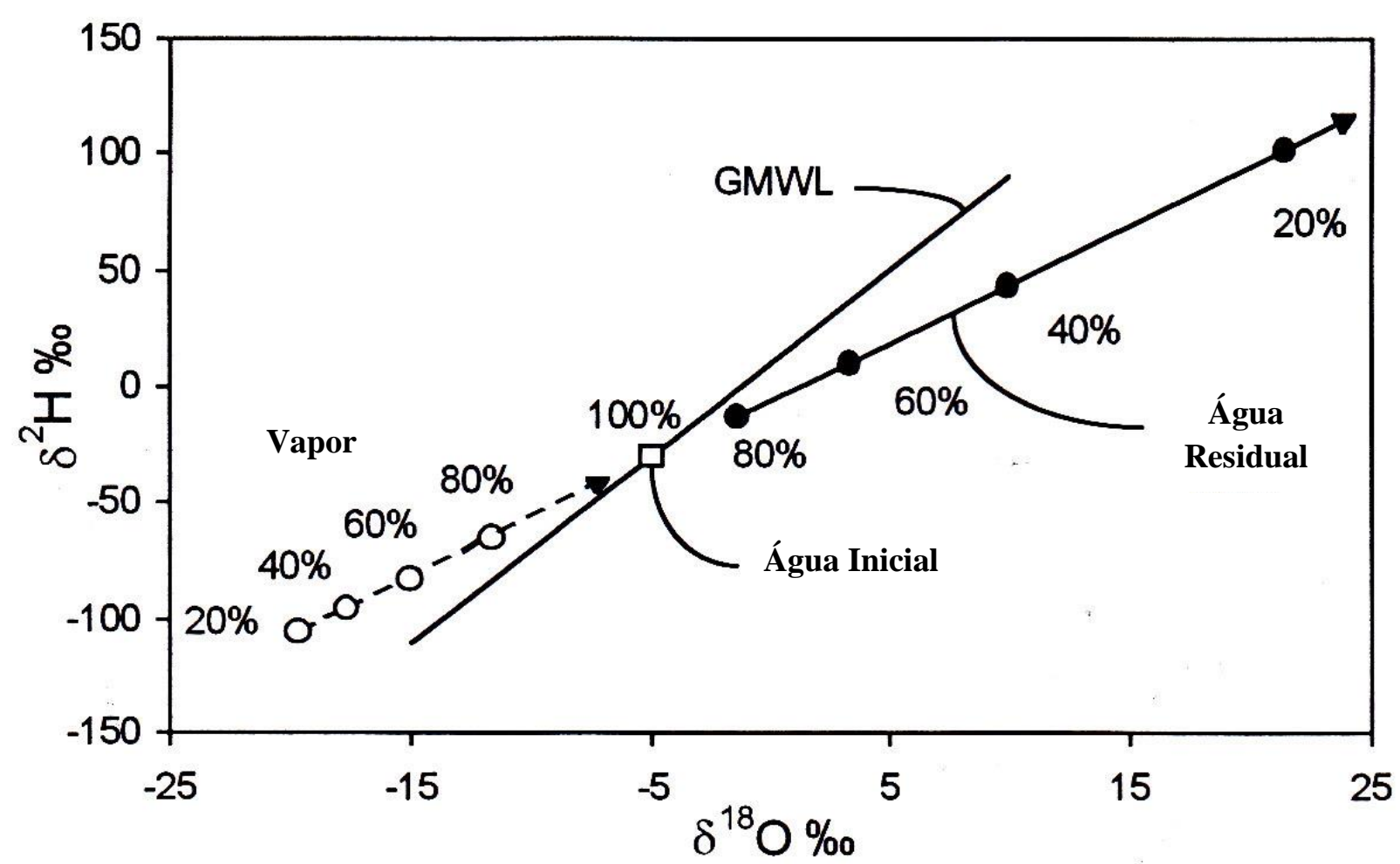

Figura 3.16 - Alteração na GMWL decorrente do fenômeno excesso de deutério que ocorre em regiões áridas e semiáridas (Adaptado de ARAGUÁS, 2014).

Durante o fluxo no aquífero, 3 processos são principais na evolução do fracionamento isotópico das moléculas de água e de seus componentes dissolvidos (GEYH, 2001):

1) Evaporação e condensação: interação líquido-vapor;

2) Reações químicas entre o $\mathrm{CO}_{2}$ gasoso, dissolução e precipitação de carbonatos que envolve principalmente o fracionamento do carbono;

3) Processos de metabolismo microbiológico como dessulfurizarão, desnitrificação e nitrificação que causa o fracionamento do nitrogênio, enxofre e oxigênio.

Já em sistemas de alta temperatura (geotermais), trocas isotópicas significativas de $\mathrm{O}$ e $\mathrm{H}$ ocorrem entre a água e a rocha devido às camadas de argilas semipermeáveis e a hidratação e desidratação de minerais secundários (GEYH, 2001).

Isótopos de estrôncio são exceções a esse processo e por isso estão sendo utilizado nos estudos de interação água-rocha nos aquíferos. O estrôncio possui 4 isótopos estáveis $\left({ }^{84} \mathrm{Sr},{ }^{86} \mathrm{Sr}\right.$, ${ }^{87} \mathrm{Sr}$ e ${ }^{88} \mathrm{Sr}$ ) que ocorrem naturalmente sendo que o ${ }^{87} \mathrm{Sr}$ é derivado do decaimento do ${ }^{87} \mathrm{Rb}$. Dessa forma, a razão ${ }^{87} \mathrm{Sr} /{ }^{86} \mathrm{Sr}$ de uma rocha depende do quantitativo de $\mathrm{Rb}$ presente e da idade da rocha. Rochas antigas são mais enriquecidas em $\mathrm{Rb}$ e possuem valores maiores, já as rochas jovens possuem pouco Rb possuem menores razões. Não foi observado em processos naturais o fracionamento dos isótopos de estrôncio ( $\mathrm{Sr}$ ). O Sr possui propriedades geoquímicas similares ao cálcio e substitui os íons de cálcio em carbonatos, sulfatos, feldspatos e outros minerais formadores de rocha. Porém, devido a pequena concentração desse elemento nas águas subterrâneas, a interação água-rocha pode resultar, após um tempo suficiente, em um equilíbrio isotópico com respeito ao Sr. Esse processo pode ser analisado comparando a razão ${ }^{87} \mathrm{Sr} /{ }^{86} \mathrm{Sr}$ dos minerais da rocha primária; dos minerais secundários localizados nas fraturas, juntas e poros; e da água subterrânea (ALLÈGRE, 2008). 
Em caso de carbonatos, as águas subterrâneas tendem a refletir a razão ${ }^{87} \mathrm{Sr} /{ }^{86} \mathrm{Sr}$ da rocha total, pois essas rochas são essencialmente homogêneas com respeito ao Sr. Já nos silicatos, a razão ${ }^{87} \mathrm{Sr} /{ }^{86} \mathrm{Sr}$ resultante do intemperismo é dominante sob a composição isotópica de minerais específicos o que resulta em águas subterrâneas com razões diferentes da razão da rocha total, porém correspondente a razão dos minerais de alteração (MONTGOMERY et al., 2006).

Águas subterrâneas de diferentes origens podem conter diferentes razões de Sr o que o torna um bom instrumento nos estudos de origem, fluxo e mistura de águas subterrâneas. Além do estudo da interação água-rocha (GEYH, 2001).

Estudos já foram realizados nesse sentido no Escudo Pré-Cambriano do Canadá e em Mont-Dore na região do Massif-central na França (GEYH, 2001).

A razão ${ }^{87} \mathrm{Sr} /{ }^{86} \mathrm{Sr}$ dos oceanos é constante e de 0,70917 , a médias dos valores dos rios é de 0,712 , a média das rochas vulcânicas varia de 0,7030 a 0,7035 e a média dos silicatos da crosta continental é de 0,724 (ALLÈGRE, 2008).

Montgomery et al. (2006), utilizou análises de ${ }^{87} \mathrm{Sr} /{ }^{86} \mathrm{Sr}$ para estudo forense em águas subterrâneas da Grã Bretanha. As análises foram realizadas em amostras de águas minerais engarrafadas e de rochas dos referidos aquíferos para determinar os reservatórios fontes de cada água (Figura 3.17).

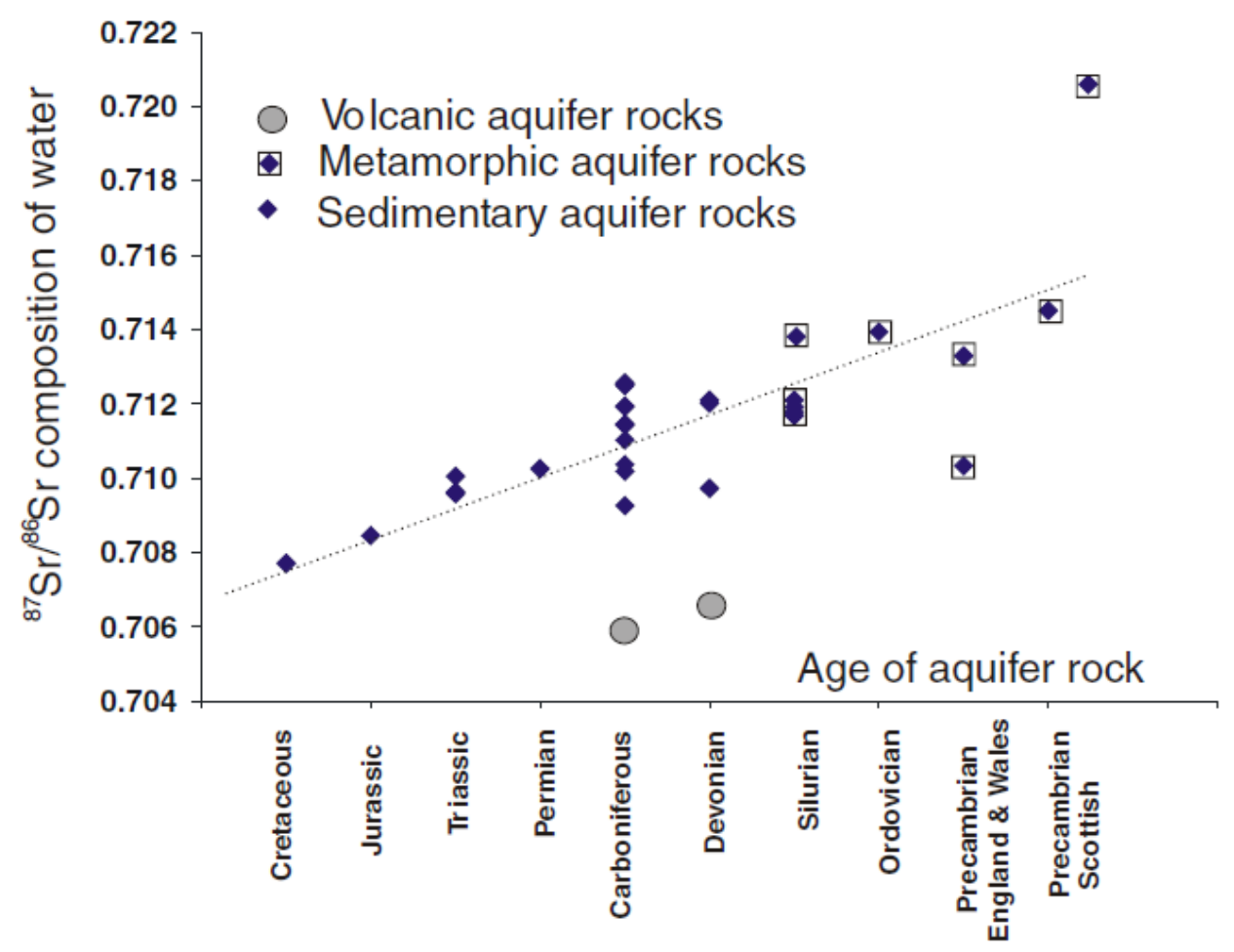

Figura 3.17 - Composição isotópica de ${ }^{87} \mathrm{Sr} /{ }^{86} \mathrm{Sr}$ de amostras de águas engarrafadas plotadas de acordo com a estratigrafia e com a assinatura dos aquíferos fonte das águas (MONTGOMERY et al., 2006).

Os autores observaram que quanto mais antigas as rochas do aquífero maiores as razões ${ }^{87} \mathrm{Sr} /{ }^{86} \mathrm{Sr}$ o que é condizente com o maior tempo de decaimento do Rb. Os autores concluíram também, que a utilização da comparação das razões de ${ }^{87} \mathrm{Sr} /{ }^{86} \mathrm{Sr}$ em amostras de água mineral com a das rochas dos aquíferos possui grande potencial para análise das fontes de água subterrânea e no combate de fraudes (MONTGOMERY et al., 2006). 
Conforme já explicitado anteriormente, análises de isótopos estáveis possuem respostas satisfatórias em estudos de misturas de águas com características isotópicas distintas. Em sistemas de recarga artificial essa ferramenta pode ser utilizada para verificar a chegada de água de recarga na zona saturada dos aquíferos. A precisão e a rapidez da resposta do método na chegada da recarga reforça a importância de sua utilização.

Os métodos isotópicos são valiosos instrumentos para monitorar sistemas de recarga artificial ainda mais quando é feita a integração de vários traçadores. Existem vários exemplos pelo mundo do sucesso da utilização de tais técnicas nesse sentido. Alguns serão citados a seguir (IAEA, 2013).

No Vale de Santa Clara, Califórnia, EUA, foram utilizados os isótopos $\mathrm{D},{ }^{18} \mathrm{O},{ }^{3} \mathrm{H}, \mathrm{He}$ e concentrações de neônio para estudar a dinâmica de fluxo da água subterrânea e monitorar sistema de recarga artificial do tipo ASR. Os resultados demarcaram a extensão, o tempo, e o fluxo em subsuperfície das águas do sistema ARS. $\delta^{18} \mathrm{O}$ auxiliou na determinação da proveniência da água de recarga dos aquíferos. As bacias de recarga superficiais injetam águas mais enriquecidas em isótopos pesados (devido a evaporação) o que gerou resultados menos negativos em poços nas áreas com influência direta da recarga artificial. A distribuição espacial do trítio permitiu a identificação dos locais de recarga recentes e indicou a direção do fluxo da água subterrânea. Os locais de menores valores de trítio foram os de maior $\delta^{18} \mathrm{O}$ representando a influência dos sistemas de recarga artificial (IAEA, 2013).

Outro exemplo é em Damasco, capital da Síria, onde isótopos são utilizados como traçadores para monitoramento de sistema de recarga artificial por injeção direta em poços. $\mathrm{O}$ aquífero raso dos aluviões da região são utilizados para armazenagem de água diminuindo as perdas por evaporação que é forte devido ao clima árido da região. Análises dos isótopos de ${ }^{18} \mathrm{O}$, $\mathrm{D},{ }^{3} \mathrm{H}, \mathrm{Cl}$, e de amostras de $\mathrm{CFC}$ foram realizadas para testar sua aplicabilidade para estudo da mistura das águas da recarga artificial com as águas do aquífero na região. As coletas foram realizadas periodicamente durante os períodos de recarga (primavera) e em períodos de não injeção. As análises de trítio e CFC não foram efetivas no estudo da mistura das águas, pois as águas de injeção e as águas do aquífero, na região de Damasco, possuíam quantidades similares desses elementos. Os autores ressaltam que esses métodos podem ser úteis onde águas jovens com presença de trítio e CFC são misturadas com águas subterrâneas antigas e sem esses elementos. Ao contrário do trítio e do CFC, os outros isótopos obtiveram bons resultados nos estudos do movimento das águas de injeção no aquífero. O principal motivo do sucesso da aplicação dos mesmos é a assinatura isotópica distinta das águas de injeção e das águas do aquífero. Os autores ressaltam também que uma das vantagens da utilização dos isótopos estáveis para monitoramento de sistemas de recarga artificial é que esses parâmetros costumam ser praticamente constante o que permite que a diferença entre eles e as águas de injeção permitem um estudo do movimento das águas de injeção e da razão de mistura entre elas. Os autores utilizaram o modelo de mistura de águas com isótopos citado acima no texto e estimaram em um máximo de 74 a $84 \%$ de contribuição das águas de injeção na mistura. A Figura 3.18 representa o monitoramento do sistema (IAEA, 2013). 


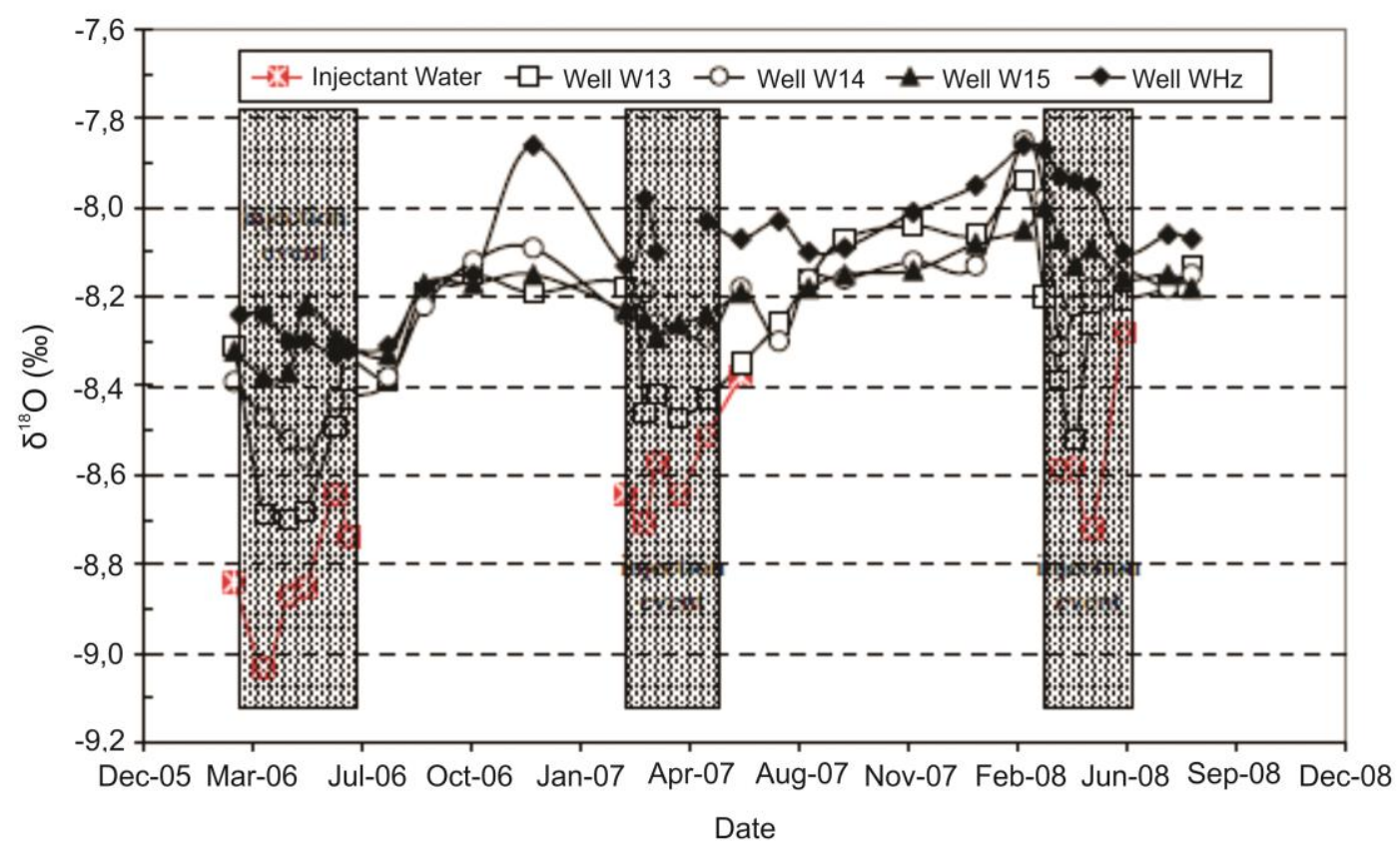

Figura 3.18 - Variação temporal do $\delta^{18} O(\%)$ durante 3 períodos de injeção de água no sistema de recarga artificial em injeção direta em poços em Damasco, capital da Síria. Os 3 retângulos indicados representam os 3 períodos de injeção, Os pontos vermelhos indicam a assinatura da água de injeção, os pontos brancos a assinatura das águas dos poços que responderam positivamente a recarga (W13 e W14) e os pontos pretos a assinatura dos poços que não responderam a recarga (W15 e WHz) (IAEA, 2013).

\subsubsection{Isótopos Radiogênicos em Hidrogeologia}

Os isótopos radiogênicos sofrem variações em suas massas (decaimento) decorrentes de emissões de energia ou partículas subatômicas. Diferentemente dos isótopos estáveis que não alterarem suas massas ao longo de sua existência (MOOK, 2001).

Se o núcleo do átomo possui um excesso de nêutrons ou prótons ele irá se desintegrar em algum momento de sua vida na tentativa de formar um núcleo estável. Radioatividade é um fenômeno no qual certo átomo (átomo pai) se transforma espontaneamente em outro (átomo filho) liberando partículas ou radiação de forma a satisfazer as leis de conservação de energia e massa descritas por Einstein (ALLĖGRE, 2008). A lei do decaimento radioativo se baseia no fato de que esse processo é puramente estatístico, onde a probabilidade de decaimento é uma propriedade dos átomos que permanece inalterada ao longo do tempo. Essa probabilidade depende do grau de instabilidade do átomo pai e é expresso na forma do tempo de meia vida. $\mathrm{O}$ tempo de meia vida é definido como o tempo em que metade dos átomos radioativos desaparece (MOOK, 2001).

O decaimento radioativo pode ser expresso pela equação exponencial denominada Lei do Decaimento Radioativo:

$$
N(t)=N^{0} \cdot e^{-\lambda t}
$$

Onde, $\mathrm{N}$ é o número de núcleos radioativos no tempo $\mathrm{t}, \mathrm{N}^{0}$ é o número de núcleos radioativos iniciais, $\mathrm{t}$ é o tempo e $\lambda$ é a constante de decaimento que expressa à probabilidade que um núcleo tem de sofrer decaimento por unidade de tempo (dN/dt) (MOOK, 2001). A lei do decaimento permanece inalterada independente do meio (sólido, líquido ou gasoso) e das condições de temperatura ou pressão. E $\lambda$ não varia com o tempo (ALLĖGRE, 2008).

O tempo de meia vida $\left(T_{1 / 2}\right)$ em termos do $\lambda$ é expresso pela equação: 


$$
\lambda=\frac{\ln 2}{T_{1 / 2}}
$$

A variável "A" denominada radioatividade, atividade ou taxa de decaimento representa o número de desintegrações por unidade de tempo e é expressa em desintegrações por segundo (Becquerel-Bq), ou desintegrações por minuto (dpm). Já a variável "a" é a razão de decaimento e representa a comparação entre a taxa de decaimento da amostra e de um padrão sob as mesmas condições. Em circunstâncias naturais o valor de "a" é entre 0 e 1 e para evitar o uso de casas decimais ele geralmente é representado em porcentagem (MOOK, 2001).

$$
A=\frac{-d N}{d t}=\lambda \cdot N \quad a=\frac{A_{\text {amostra }}}{A_{\text {padrão }}}
$$

A lei do decaimento radioativo também pode ser expressa em termos da atividade dos isótopos (SANTIAGO et al., 2008):

$$
A(t)=A^{0} \cdot e^{-\lambda t}
$$

Em termos do tempo de meia vida temos:

$$
N(t)=N^{0} \cdot e^{\frac{-\ln 2 . t}{T_{1 / 2}}} \quad A(t)=A^{0} \cdot e^{\frac{-\ln 2 . t}{T_{1 / 2}}}
$$

A dificuldade na utilização dessas equações está na determinação do número de átomos radioativos no tempo 0. Dessa forma, Allègre (2008) mostra que através de substituição de fórmulas é possível chegar a uma equação que depende somente do número de átomos radioativos $\left(\mathrm{N}_{\mathrm{R}}\right)$ e de átomos filho $\left(\mathrm{N}_{\mathrm{D}}\right)$ no tempo $\mathrm{t}$ e do quantitativo de átomos filho no momento inicial. A equação fica dessa maneira:

$$
N_{D}(t)=N_{D}(0)+N_{R}(t)\left(e^{\lambda t}-1\right)
$$

Onde $\mathrm{N}_{\mathrm{D}}(\mathrm{t})$ e $\mathrm{N}_{\mathrm{R}}(\mathrm{t})$ são os números de átomos filho e pai (radioativo) no tempo $\mathrm{t}$, respectivamente. $\mathrm{E}_{\mathrm{D}}(0)$ é o número de átomos filho no tempo 0 (ALLÈGRE, 2008).

Devido às circunstâncias descritas acima, os isótopos radioativos são utilizados para datação de materiais hidrogeológicos. Sendo que os mais utilizados para datação da água subterrânea são o trítio $\left({ }^{3} \mathrm{H}\right)$ e o carbono $\left({ }^{14} \mathrm{C}\right)$. Em casos especiais, há relatos de utilização de crípton $\left({ }^{81} \mathrm{Kr}\right.$ e $\left.{ }^{85} \mathrm{Kr}\right)$, argônio $\left({ }^{39} \mathrm{Ar}\right)$, cloro $\left({ }^{36} \mathrm{Cl}\right)$, entre outros para avaliar idades relativas e absolutas de água subterrânea (GEYH, 2001).

Mook (2001) define a idade da água subterrânea como o tempo decorrido desde quando a água se tornou subterrânea, ou seja, desde a infiltração no solo.

A utilização do decaimento radioativo para datação da água subterrânea depende da quantidade de ${ }^{14} \mathrm{C}$ dissolvido na água ou do quantitativo de trítio presente nas moléculas de água na hora da infiltração. O trítio possui tempo de meia vida de 12,3 anos, já o carbono de 5.730 anos. Sendo assim, o método do carbono é indicado para amostras de água mais antigas (até 40.000 anos segundo Araguás (2001); entre 500 e 40.000 anos segundo Santiago et al. (2008); até 50.000 anos segundo Geyh (2001)) e o método do trítio para águas mais jovens (até 60 anos segundo Araguás (2001); até 50 anos segundo Santiago et al. (2008)). O crípton é utilizado para águas mais antigas ainda (chamadas águas fósseis). 
Mook (2001) alerta que as datações de água subterrânea são um processo complexo e dificilmente um único método resulta em idades absolutas. Essa dificuldade se deve ao fato da dificuldade de obter dados sobre o tempo zero, ou seja, o momento da infiltração. Entretanto, o autor relata que os métodos oferecem a possibilidade de estabelecer intervalos de idades em especial quando combinados com dados hidrogeológicos e hidroquímicos.

O decaimento radioativo é a base para determinação das idades das águas subterrâneas. Apesar de esse processo depender exclusivamente do tempo de meia vida do isótopo pai, alguns processos químicos e físicos que ocorrem nos aquíferos podem influenciar nos resultados obtidos. Por exemplo: A dissolução de carbonatos sem ${ }^{14} \mathrm{C}$; troca de íons entre água e as rochas; poluição de isótopos radioativos causados pela atividade humana como as explosões nucleares; mistura de águas de diferentes idades nos aquíferos (GEYH, 2001).

A ocorrência natural do isótopo radioativo de carbono $\left({ }^{14} \mathrm{C}\right)$ foi reconhecida em 1946 por W. F. Libby. Ele é naturalmente formado na região da transição entre a estratosfera e a troposfera a aproximadamente $12 \mathrm{Km}$ de altitude através da reação:

$$
N^{14}+n \rightarrow C^{14}+p
$$

Onde $\mathrm{n}$ é um nêutron e $\mathrm{p}$ é um próton. A produção de ${ }^{14} \mathrm{C}$ na atmosfera pode ser considerada grosseiramente constante, já no subsolo sua produção é negligenciável (GEYH, 2001; ALLÈGRE, 2008).

Os nêutrons são produzidos por reações entre os raios cósmicos primários de energia muito alta e moléculas da atmosfera nessa região e reage com $\mathrm{N}$ presente na atmosfera gerando o ${ }^{14} \mathrm{C}$. $\mathrm{O}{ }^{14} \mathrm{C}$ então oxida formando ${ }^{14} \mathrm{CO}_{2}$ que se mistura com o $\mathrm{CO}_{2}$ atmosférico. A concentração de ${ }^{14} \mathrm{CO}_{2}$ na atmosfera é variável, sendo que sua produção principal é pela interação dos raios cósmicos com o nitrogênio atmosférico, mas ela também sofre influência da emissão de $\mathrm{CO}_{2}$ sem ${ }^{14} \mathrm{C}$ pela queima de combustíveis fósseis e pela produção de ${ }^{14} \mathrm{C}$ pela interação dos nêutrons, liberados nas reações de fissão e fusão durante explosões nucleares, com a atmosfera (Figura 3.19). Durante a interação entre o $\mathrm{CO}_{2}$ atmosférico com o carbono dissolvidos nos oceanos, o ${ }^{14} \mathrm{C}$ entra no ciclo hidrológico. Ele também é absorvido pelas plantas. Todos os seres vivos incluindo plantas e animais contem concentração de ${ }^{14} \mathrm{C}$ aproximadamente iguais aos do $\mathrm{CO}_{2}$ atmosférico (MOOK, 2001).

O carbono 14 sofre decaimento do tipo ß- onde um nêutron se transforma em um próton, no interior de seu núcleo. E, como consequência, emite um elétron (partícula $\beta^{`}$ ).

$$
C^{14} \rightarrow N^{14}+B^{-}
$$

A energia máxima emitida nesse processe é de $156 \mathrm{keV}$, o $\lambda$ é $1,209 \times 10^{-4}$ anos $^{-1}$ e o tempo de meia vida do ${ }^{14} \mathrm{C}$ é de $5.730 \pm 40$ anos por convenção para dados hidrológicos e hidrogeológicos (MOOK, 2001; ALLÈGRE, 2008).

A produção e distribuição do ${ }^{14} \mathrm{C}$ na natureza ocorrem por uma série de processos químicos e biológicos que permaneceram paralisados durante um longo período do tempo geológico. Como consequência, a concentração de ${ }^{14} \mathrm{C}$ na atmosfera, nos oceanos e na biosfera alcançou um valor estacionário que tem sido quase constante durante um longo período comparado com o tempo de vida do ${ }^{14} \mathrm{C}$. A concentração natural ${ }^{14} \mathrm{C} / \mathrm{C}$ é da ordem de $10^{-12}$ (MOOK, 2001). 


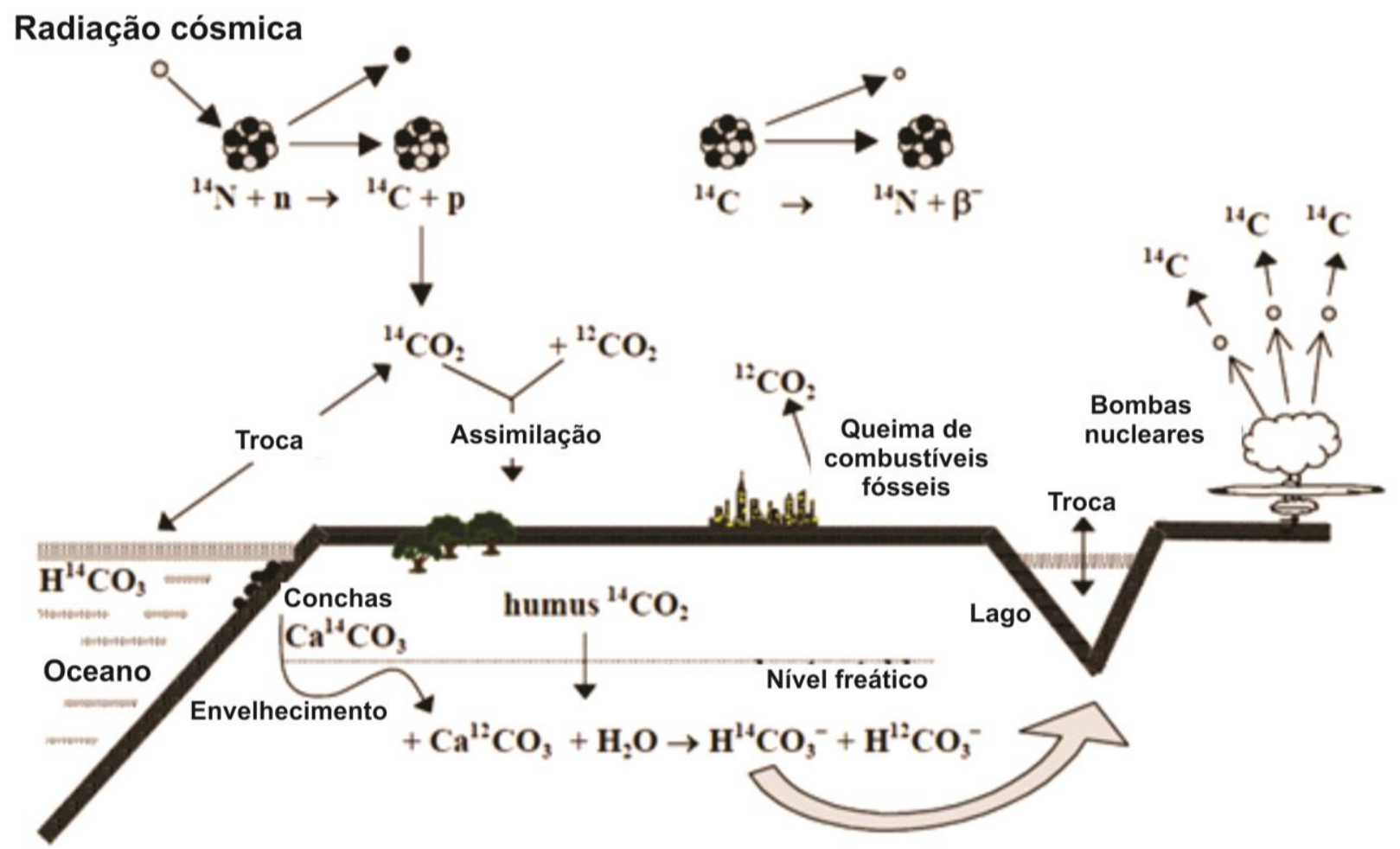

Figura 3.19 - Formação do ${ }^{14} \mathrm{C}$ e suas principais ocorrências na natureza (Adaptado de MOOK, 2001).

$\mathrm{O}{ }^{14} \mathrm{C}$ dos solos é oriundo da erosão e sedimentação de rochas carbonáticas e fossilíferas jovens e da assimilação de $\mathrm{CO}_{2}$ atmosférico pelas plantas. Esse ${ }^{14} \mathrm{C}$ é carreado durante a infiltração da água da chuva atingindo assim os aquíferos na forma de carbono inorgânico dissolvido. Os carbonatos e rochas fossilíferas mais antigas não possuem mais ${ }^{14} \mathrm{C}$. A Figura 3.20 ilustra de maneira esquemática a chegada do ${ }^{14} \mathrm{C}$ nos aquíferos.

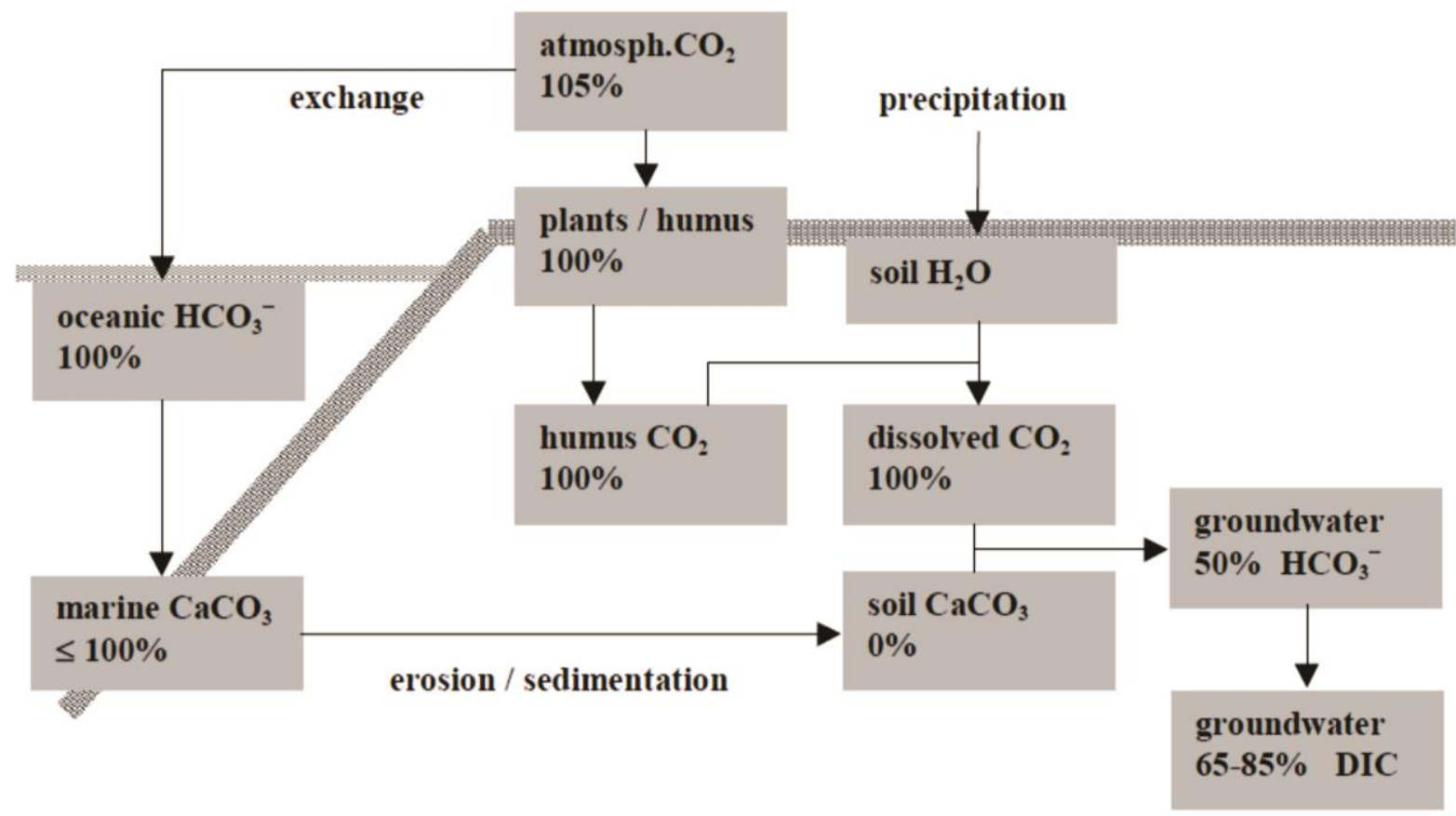

Figura 3.20 - Representação esquemática da chegada do ${ }^{14} \mathrm{C}$ nos aquíferos. As porcentagens representadas na figura se referem à razão de atividade do ${ }^{14} \mathrm{C}\left({ }^{14}\right.$ a) que representa a comparação da taxa de decaimento do ${ }^{14} \mathrm{C}$ da amostra com a de um padrão. DIC significa carbono inorgânico dissolvido (MOOK, 2001). 
A radioatividade ou taxa de decaimento do ${ }^{14} \mathrm{C}\left(\mathrm{A}^{14}\right)$ é expressa em $\mathrm{Bq} / \mathrm{gC}$ ou dpm/gC. Já a variável $a^{14}$ é a razão de decaimento e representa a comparação entre a taxa de decaimento da amostra e de um padrão sob as mesmas condições. O padrão para a razão de decaimento foi escolhida para representar o mais próximo possível à quantidade de ${ }^{14} \mathrm{C}$ no crescimento natural de plantas. Ele se chama AD1950 e é baseado em 95\% da atividade específica do ácido oxálico NBS original (Ox1) no ano de 1950. Seu valor é $13,56 \pm 0,07 \mathrm{dpm} / \mathrm{gC}$ ou $0,226 \pm 0,001 \mathrm{~Bq} / \mathrm{gC}$. O suprimento do padrão Ox1 foi exaurido, dessa forma uma nova bateria foi elaborada e distribuída pelo NIST (US- National Bureau of Standards) chamada Ox2. O padrão (Ox2) = $(1,2736 \pm 0,0004) \times(O x 1)(\mathrm{MOOK}, 2001)$.

A equação que rege a datação por ${ }^{14} \mathrm{C}$ é (ALLÈGRE, 2008):

$$
T=\left(\frac{T_{\frac{1}{2}}}{\ln 2}\right) \cdot \ln \frac{A_{t}^{14}}{A_{0}^{14}} \quad \text { ou } \quad T=\left(\frac{T_{\frac{1}{2}}}{\ln 2}\right) \cdot \ln \frac{N^{0}}{N}
$$

Onde T é a idade da amostra, A é a atividade do ${ }^{14} \mathrm{C}$ inicial e no tempo t. Substituindo os valores conhecidos da equação (Figura 3.21), temos:

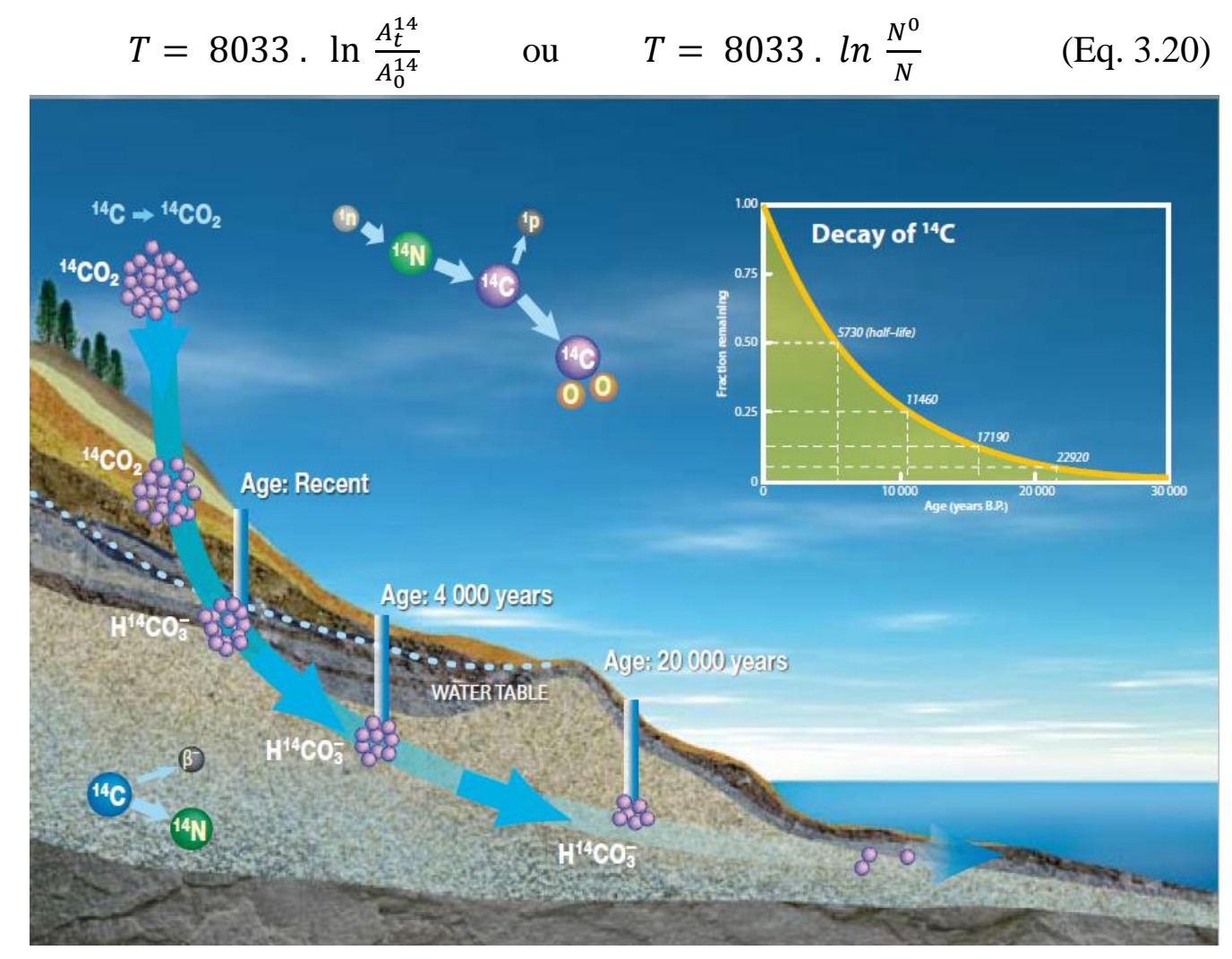

Figura 3.21 - Ilustração esquemática da forma de utilização do isótopo de Carbono 14 para datação de água subterrânea.

O tempo de meia vida utilizado na equação acima é 5.567 anos (chamado convencional) ao invés da correta de 5.730 anos. Os laboratórios optaram por continuar realizando o cálculo com o valor menos preciso ao invés de trocá-lo pelo mais recente, pois esta mudança resultaria em idades que diferem das convencionais menos que $3 \%$ o que é insignificante considerando as incertezas metodológicas e estatísticas (SANTIAGO et al., 2008).

Os isótopos radioativos, assim como os isótopos estáveis, também sofrem fracionamento durante os processos naturais. Dessa forma, esse fracionamento deve ser levado em consideração 
na determinação de idades para evitar erros. O grau de fracionamento é indicado pelo valor de $\delta^{13} \mathrm{C}$ do material. Martinelli et al. (2009) explana que por um acordo internacional todo resultado de ${ }^{14} \mathrm{C}$ deve ser corrigido pelo desvio de $\delta^{13} \mathrm{C}$, sendo que se for utilizado o padrão Ox1 por $\delta^{13} \mathrm{C}$ $=-19 \%$, se o padrão utilizado for o $\mathrm{Ox} 2$ por $\delta^{13} \mathrm{C}=-25 \%$ (MOOK, 2001). Porém, Araguás (2014) considera que a variação $\delta^{13} \mathrm{C}$ deve ser omitida dos cálculos, pois é insignificante para aplicações de hidrologia isotópica (Figura 3.22).

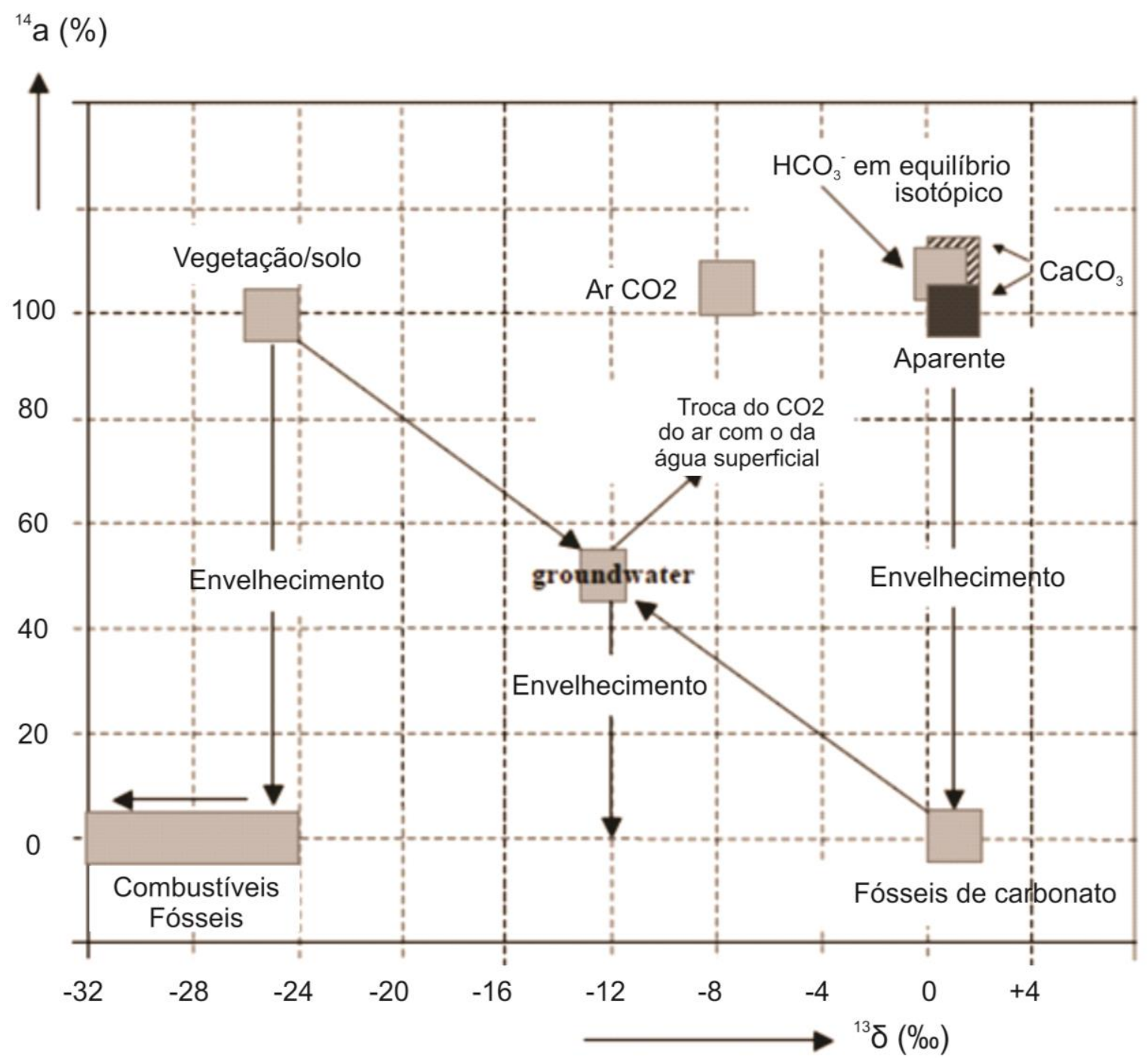

Figura 3.22 - Representação gráfica da razão de decaimento do ${ }^{14} \mathrm{C}$ e do $\delta^{13} \mathrm{C}$ para os principais elementos do ciclo hidrológico (Adaptado de MOOK, 2001).

A utilização da fórmula exposta para datação está atrelada a aproximações e simplificações, como por exemplo: o tempo de meia vida é um dado estimado; a premissa de que a quantidade de ${ }^{14} \mathrm{C}$ das plantas no planeta é constante não é verdadeira. Dessa forma, foi criada uma curva de calibração de ${ }^{14} \mathrm{C}$ para transformar as idades obtidas em idades reais (Figura 3.23). A curva foi elaborada com a relação entre a variação do quantitativo de ${ }^{14} \mathrm{C}$ no $\mathrm{CO}_{2}$ atmosférico com a datação precisa e acurada de anéis de árvores e pelo crescimento anual de corais. As análises foram feitas por vários laboratórios renomeados (MOOK, 2001). 

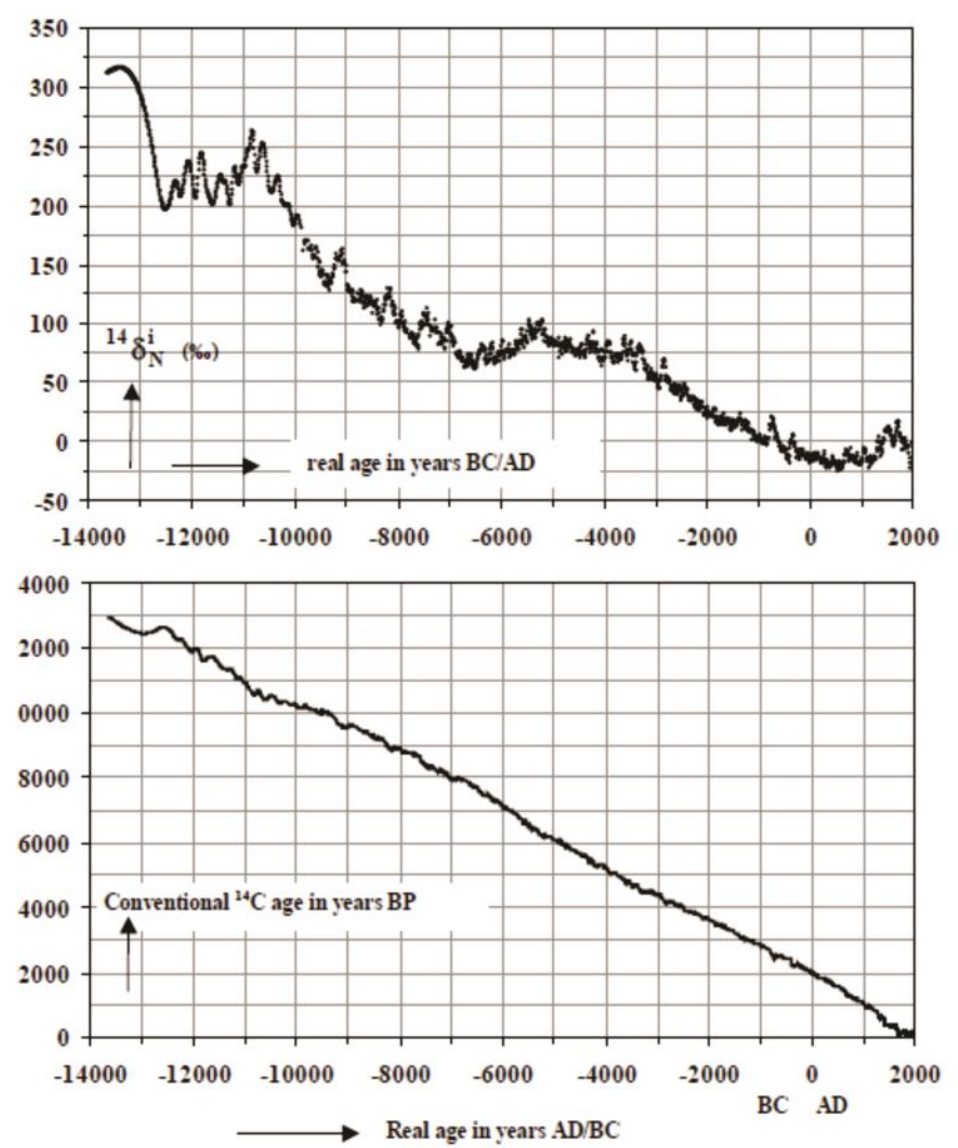

Figura 3.23 - Curva de calibração do ${ }^{14} \mathrm{C}$. Na imagem superior, a relação entre a variação do quantitativo de ${ }^{14} \mathrm{C}$ no $\mathrm{CO}_{2}$ atmosférico com a datação acurada de idade de anéis de árvores por vários laboratórios e pelo crescimento anual de corais. Na curva inferior, a curva de calibração obtida com base na imagem superior (Adaptado de MOOK, 2001).

Algumas atividades antrópicas nos últimos séculos alteraram os valores de ${ }^{14} \mathrm{C}$ da atmosfera como a queima de combustíveis fósseis, que passou a introduzir $\mathrm{CO}_{2}$ isento de ${ }^{14} \mathrm{C}$ na atmosfera dando uma contribuição de $10 \%$ ao $\mathrm{CO}_{2}$ atmosférico (denominado Efeito Suess); e os testes de bombas nucleares que injetaram uma enorme quantidade de ${ }^{14} \mathrm{C}$ para atmosfera na década de 60. Por esses motivos, a atividade atual da atmosfera não serve como valor inicial para a datação de águas na faixa de 500 a 50.000 anos. Por isso, usa-se como valor inicial a atividade do padrão de ácido oxálico AD1950 fornecido pela IAEA medida em 1950 e corrigida pelo Efeito Suess. Quando isso ocorre, a idade obtida pela equação se refere há quantos anos a amostra tinha em 1950 (MOOK, 2001; SANTIAGO et al., 2008).

Para a datação de amostras de água subterrânea, a atividade inicial de carbono 14 é o presente no momento da recarga do aquífero. E em geral a atividade do carbono dissolvido nas águas na hora da recarga não é igual ao da atmosfera, e depende do ambiente hidrogeoquímico na área da recarga e do aquífero. Assim, faz-se necessário determinar um fator para correção da atividade inicial (entre 0,5 e 1). Isso é feito através de modelos que consideram os diferentes processos de formação dos carbonatos. Os modelos mais utilizados são: modelo hidroquímico, modelo isotópico e modelo exponencial (SANTIAGO et al., 2008).

A água subterrânea contém carbono inorgânico (DIC - Dissolved Inorganic Carbon) e orgânico (DOC - Dissolved Organic Carbon) dissolvidos. Os métodos de datação que utilizam cada forma de ocorrência do carbono são distintos (MOOK, 2001).

A datação utilizando o carbono do DIC possui amostragem e análise relativamente simples, porém o tratamento dos dados e a obtenção de resultados confiáveis não são tão simples. Os compostos do DIC são susceptíveis a reações hidroquímicas com as rochas dos aquíferos. O carbono inorgânico dissolvido é formado por 2 principais processos. $\mathrm{O}$ primeiro é a dissolução do carbono do $\mathrm{CO}_{2}$ atmosférico (em regiões áridas) e do solo pelo íon $\mathrm{H}^{+}$em $\mathrm{H}_{2} \mathrm{CO}_{3}$; e o segundo é a troca isotópica da água com o $\mathrm{CO}_{2}$ do solo ou da atmosfera na zona vadosa 
(aliado a um equilíbrio isotópico). Nesse método se assume que o valor de $\mathrm{A}^{14}$ inicial é igual ao do padrão, porém esse fato nem sempre é verídico. Assim, as correções por diluição química e isotópica são utilizadas para a correção desses valores (MOOK, 2001).

Os compostos orgânicos (DOC) são solúveis em água em condições ácidas e são decompostos em ácido fúlvico e húmico dependendo das condições do meio. Essas moléculas são relativamente resistentes à degradação. Mook (2001) relata que alguns autores consideram que somente a fração de ácido fúlvico pode ser considerada confiavelmente como originada no solo e assim pode ser utilizada com confiança para datação. A datação utilizando DOC pode prevenir a interferência das reações hidroquímicas que ocorrem na datação do DIC, porém a contribuição de carbono orgânico sedimentar antigo pode ser estimada juntamente com a amostra atrapalhando o resultado. Dessa forma, as datações do DOC e do DIC são complementares (GEYH, 2001).

$\mathrm{O}$ trítio $\left({ }^{3} \mathrm{H}\right)$ é formado de forma semelhante ao ${ }^{14} \mathrm{C}$, principalmente, pela reação do nitrogênio atmosférico com nêutrons na região da transição entre a estratosfera e a troposfera.

$$
N^{14}+n \rightarrow C^{12}+H^{3}
$$

O trítio entra no ciclo hidrológico quando se oxida formando a molécula de água $\left({ }^{1} \mathrm{H}^{3} \mathrm{HO}\right)$. Seu decaimento também é do tipo $B^{-}$onde um nêutron se transforma em um próton, no interior de seu núcleo e como consequência, emite um elétron (partícula $\beta^{-}$). A energia máxima liberada nesse processo é de $18 \mathrm{KeV}$ e o tempo de meia vida do trítio é de 12, 32 anos (MOOK, 2001).

$$
H^{3} \rightarrow H e^{3}+\beta^{-}
$$

A taxa de decaimento do trítio $\left(\mathrm{A}^{3}\right)$ é representado em $\mathrm{Bq} / \mathrm{L}$ de água ou em Unidade de Trítio (UT) que é equivalente a $10^{-18}$. O padrão utilizado para o cálculo da razão de decaimento $\left(\mathrm{a}^{3}\right)$ do trítio é chamada NBS-SRM 4361 e corresponde a 11.100 UT. Ela foi elaborada pela IAEA e pelo NIST em setembro de 1978 (MOOK, 2001).

A concentração de trítio em precipitações sob condições naturais é de aproximadamente 5 UT que equivale a $0,6 \mathrm{~Bq} / \mathrm{L}$ de água. Na Figura 3.24 é possível observar a origem e o transporte do trítio ao longo do ciclo hidrológico.

Assim como para o carbono, o trítio também é gerado em processos de explosão nuclear. $\mathrm{Na}$ década de 60, durante os seguidos testes nucleares que ocorreram, a concentração de ${ }^{3} \mathrm{H}$ nas precipitações chegou a aumentar 1.000 vezes no hemisfério norte (Figura 3.25). Esse excesso de trítio foi decaindo com o passar do tempo e grande parte foi injetada na estratosfera e retorna para a troposfera todo ano durante a primavera e o início do verão (o tempo de residência do trítio na estratosfera é de alguns anos e na troposfera de 5 a 20 dias). Isso causa uma variação sazonal tanto na concentração do trítio, quanto na de carbono 14 (no verão e primavera os valores são mais elevados, e no inverno são mais brandos). Essa variação é mais pronunciada no trítio, pois o tempo de residência das moléculas de água (onde o trítio se aloja) na atmosfera é muito pequeno comparativamente ao carbono. Já para o hemisfério sul, o valor de elevação do teor de trítio na atmosfera foi de 10 a 100 vezes menor do que no hemisfério norte; e a variação sazonal não ocorre de maneira expressiva sendo que o acumulado gerado na primavera é rapidamente consumido e retorna para a normalidade (MOOK, 2001; GAT et al., 2001). 


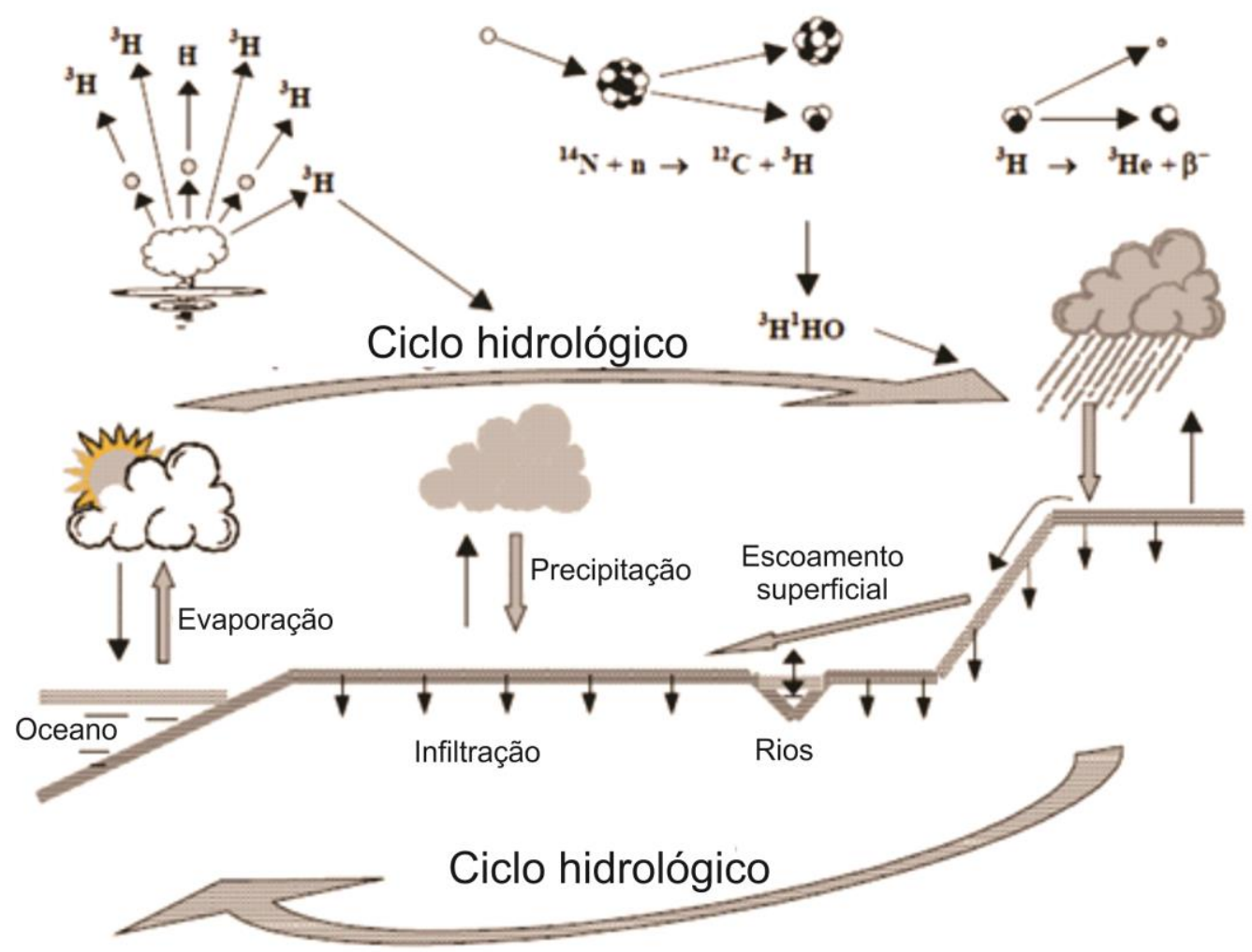

Figura 3.24 - Origem e distribuição do trítio na natureza. Ao contrário do ${ }^{14} \mathrm{C}$, o trítio decai e desaparece mais rapidamente, exceto quando está fixado em geleiras e na água subterrânea (Adaptado de MOOK, 2001).

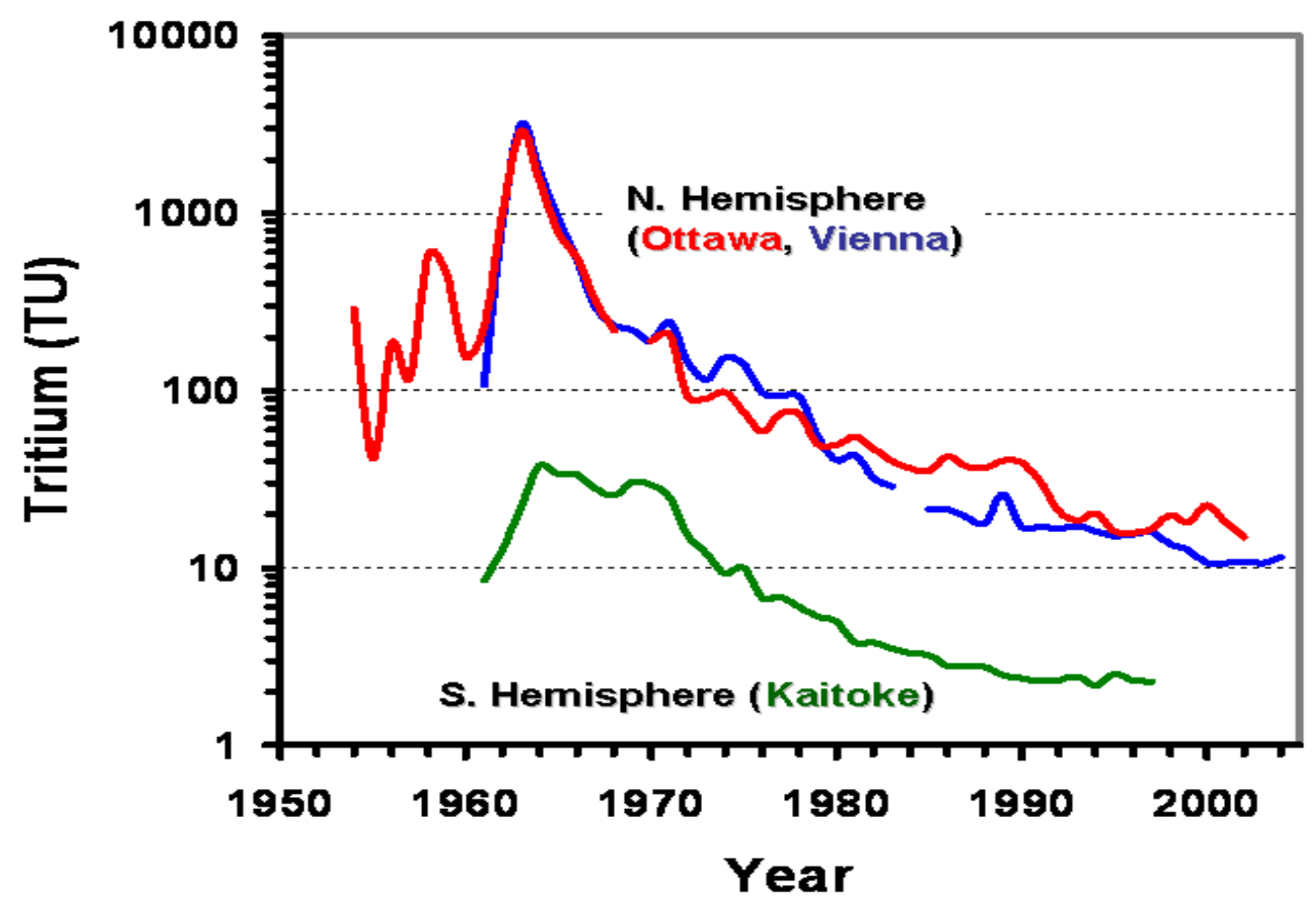

Figura 3.25 - Variação do Trítio em 2 estações sendo uma representante do hemisfério norte e outra do hemisfério sul (ARAGUÁS, 2014). 
A datação por Trítio permite uma estimativa do tempo de residência de águas subterrâneas rasas e de nascentes em terrenos fraturados de idades inferiores há 150 anos. O método é baseado na concentração de trítio nas águas das chuvas. Suas aplicações foram limitadas pela subida drástica de valores durante a década de 60 . Na prática, o uso do trítio é limitado à observação da marca que os testes nucleares imprimiram na atmosfera juntamente com a aplicação do modelo exponencial, e através de interpretação qualitativa, para detecção de recarga recente. $\mathrm{O}$ modelo exponencial é comumente utilizado para interpretação de águas subterrâneas rasas e de nascentes. Séries de dados permitem uma melhor avaliação do melhor tipo de modelo a ser aplicado. Análises únicas de trítio podem resultar em tempos de residência ambíguos (GEYH, 2001; SANTIAGO et al., 2008).

Outras aplicações do trítio são: estudos de dinâmica de lagos; estimativas de taxas de recarga de aquíferos em regiões úmidas, áridas e semiáridas; e informações de misturas de águas de diferentes fontes e idades. Águas que possuem elevadas concentrações de nitrato são indicadas para utilizar análises de trítio, devido ao tempo de vida do nitrato nas águas (GEYH, 2001)

Segundo Santiago et al. (2008), existem 3 modelos para interpretação das datações por trítio amplamente utilizados para águas subterrâneas. O modelo de fluxo de pistão que se baseia em recargas que se deslocam sem se misturar; o modelo exponencial que considera a mistura de todas as recargas no aquífero; e o modelo de dispersão que é intermediário entre os 2 primeiros.

O trítio possui aplicações em sistema de recarga artificial, onde o mesmo se reequilibra com a atmosfera nos tanques de infiltração o que zera o relógio do decaimento. Toda água subterrânea que apresenta trítio mensurável teve uma recarga nos últimos 50 anos. Apesar de não permitir uma distinção entre a água de recarga natural e artificial. Estudos no Vale de Santa Clara, Califórnia, EUA utilizaram o trítio neste sentido e através da distribuição do trítio foi possível determinar o fluxo da água subterrânea (IAEA 2013).

A probabilidade de contaminação de águas jovens por trítio dos testes nucleares impede a água de ser datada somente pelo decaimento do trítio. Porém, esse método de datação é utilizado para estudos de idades relativas e comparação de amostras. Águas com $\mathrm{A}^{3}<5$ UT possui tempo de residência média de mais de 40 anos e água com $\mathrm{A}^{3}>20$ UT é datado de depois de 1961(MOOK, 2001). Outra dificuldade da aplicação da datação por Trítio é que o limite de detecção rotineiramente utilizado nas análises é de 1 UT e os valores de UT encontrados no hemisfério sul é de somente de algumas UT (SANTIAGO et al., 2008).

As variações sazonais do ${ }^{3} \mathrm{H}$ são menos importantes para a datação da água subterrânea, uma das razões são as chuvas do verão que contribuem expressivamente para a recarga da água subterrânea (GEYH, 2001).

A Figura 3.26 mostra a relação entre a razão de decaimento do trítio e do carbono 14 para água de diferentes idades. 


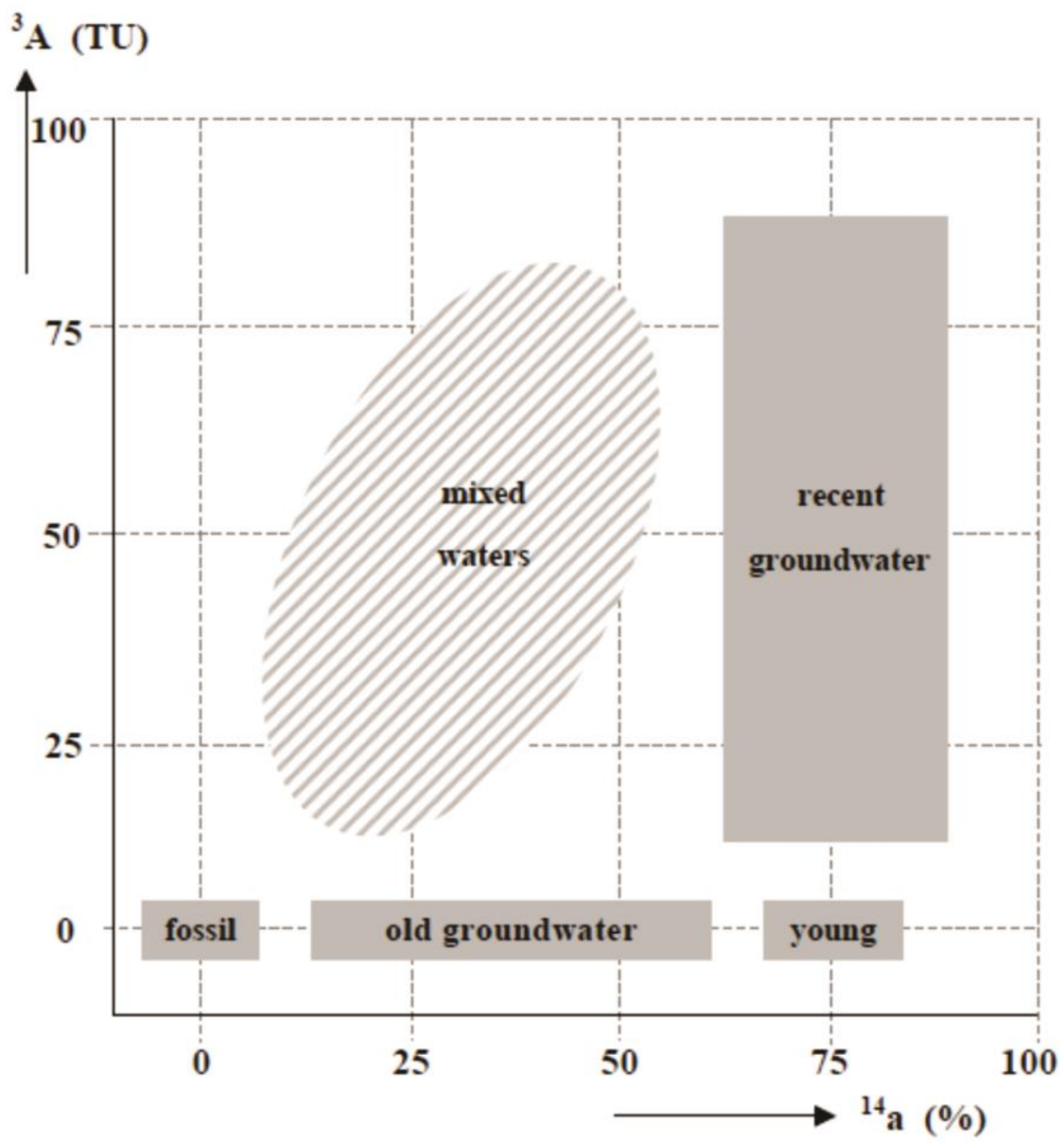

Figura 3.26 - Diagrama esquemático que representa a relação entre o ${ }^{14} \mathrm{C}$ e o ${ }^{3} \mathrm{H}$ em águas subterrâneas de diferentes idades. As águas recentes possuem dezenas de anos, águas jovens possuem centenas de anos, águas velhas possuem milhares de anos, águas muito velhas e águas fósseis possuem dezenas de milhares de anos (MOOK, 2001). 


\subsection{Salinização das Águas Subterrâneas no Semiárido do Nordeste Brasileiro}

O problema da escassez hídrica no semiárido nordestino se estende por décadas e atinge os recursos hídricos como um todo, tanto os superficiais, quanto os subterrâneos. A pouca quantidade aliada à irregularidade das chuvas na região dificultam a recarga dos aquíferos e o abastecimento dos rios.

Os recursos hídricos superficiais se resumem a rios (em sua grande maioria, intermitentes) que permanecem secos durante anos. O Rio São Francisco é o único rio perene do município de Petrolina.

Estudos de hidroquímica em águas subterrâneas e superficiais do nordeste brasileiro mostram que salinidades elevadas são comuns nessa região. A análise estatística de mais de 400 amostras de água subterrânea e superficial mostra que somente $17 \%$ têm valor do parâmetro resíduo seco menor que $1.000 \mathrm{mg} / \mathrm{L}, 50 \%$ têm valores menores que $2.900 \mathrm{mg} / \mathrm{L}, 20 \%$ têm resíduos superiores a $7.000 \mathrm{mg} / \mathrm{L}$ e $9 \%$ têm mais de $10.000 \mathrm{mg} / \mathrm{L}$ de resíduo seco. Os processos de salinização são variados e dependem de características como clima, relevo e aspectos dos aquíferos (SANTIAGO et al., 2000).

Gascoyne \& Kamineni (1994) realizaram estudos sobre a composição das águas subterrâneas de aquíferos fraturados do Escudo do Canadá. Os autores observaram que a composição química das águas apresentava uma evolução similar com aumento da profundidade e com o fluxo, independentemente das rochas que as hospedavam. Os autores relatam que próximo a superfície as águas são diluídas, levemente alcalinas (pH 7-8) e Ca-(Na)-HCO3, já em grandes profundidades $(>200 \mathrm{~m})$ e no decorrer do fluxo no aquífero estas apresentam um acréscimo no $\mathrm{pH}(\mathrm{pH} 8-10,5)$ e sua composição evoluí para $\mathrm{Na}-(\mathrm{Ca})-\mathrm{HCO} 3$. As salinidades aumentam com a profundidade $(>350-500 \mathrm{~m}$ ) como resultado da dissolução de sais das rochas e mistura com salmouras de água do mar ou de águas de formações basais. As mudanças químicas observadas no decorrer do fluxo no aquífero podem ser explicadas pela interação dessas águas com plagioclásios e argilominerais das rochas, juntamente com precipitação de calcita.

Estudos feitos comparando a composição de tais águas subterrâneas com os minerais de baixa temperatura que preenchem fraturas mostram que há uma relação entre eles. Os processos químicos envolvidos na interação água-rocha nas porções rasas das fraturas são: a hidrólise dos feldspatos que libera $\mathrm{Na}$ e $\mathrm{Ca}$ em solução, perda de Ca pela precipitação de calcita e a troca de íons com os argilominerais. Em grandes profundidades o processo dominante é a dissolução de sais da matriz das rochas. Pode haver influência de salmouras ou água de mar que imprime uma característica Na/Ca para as águas (GASCOYNE \& KAMINENI, 1994).

Dados termodinâmicos e o fato das águas salinas de grandes profundidades terem predominância do Ca sugere que o tempo de residência é o principal fator que controla a composição dos cátions independentemente da rocha (GASCOYNE \& KAMINENI, 1994).

Estudos realizados em área do cristalino do Ceará revelam que inexiste, nessa região, uma rede de fluxo regional das águas subterrâneas, sendo que os poços exploram fraturas isoladas que possuem grandes diferenças de salinidade. Datações realizadas em amostras de água subterrânea revelaram que existem águas jovens (com pouco tempo de permanência no aquífero) que possuem altas condutividades elétricas. Sendo assim, a causa da alta salinidade dessas águas pode não ter origem na interação com as rochas, pois tais processos geoquímicos, em ambiente fechado, são relativamente lentos. $\mathrm{O}$ autor sugere que as fontes mais prováveis das altas salinidades pode ser o intemperismo ou, em áreas próximas do mar, deposição de aerossóis 
anualmente lixiviados e transportados por escoamento superficial para as fraturas (SANTIAGO et al., 2000).

Costa et al. (2006) estudou aspectos da salinidade dos aquíferos fissurais do cristalino no Rio Grande do Norte. Os autores relatam que a alta salinidade observada nos aquíferos da região está ligada ao clima, que possui distribuição irregular espacial e temporal das chuvas além da alta evapotranspiração, e a baixa permeabilidade dos terrenos com reduzidas taxas de infiltração. Sendo o clima o fator dominante com influências locais de fatores de natureza geológica, modo de ocorrência das águas e das condições de circulação de água no aquífero. Nessa região foi observado que os solos influem diretamente na salinidade das águas, sendo que solos salinos são observados sobre águas salinas e vice versa.

O relevo plano e pouco movimentado, típico das regiões semiáridas, limita a circulação de água nos aquíferos fazendo com que o fluxo seja reduzido e o tempo de residência e de contato entre água-rocha seja prolongado. Além disso, em terrenos pouco permeáveis como os terrenos cristalinos, áreas planas propiciam acumulação de água na superfície que permanecem por períodos prolongados no mesmo local sendo submetidas à evaporação. Tal processo favorece o aumento da salinidade nas águas residuais (COSTA et al., 2006).

Fatores locais, também, possuem influências significativas nas salinidades das águas subterrâneas. Características ligadas ao sistema de fraturas (como conexão de fraturas) e as condições de recarga (presença de aluviões ou solo mais espesso) podem influenciar nas altas condutividades observadas nessas áreas (COSTA et al., 2006).

Lima (2010) explica a origem das altas salinidades das águas da Bacia do Alto Rio Curaçá no semiárido da Bahia. O autor relata que existe um aquífero livre superficial ligado aos saprólitos, rochas alteradas e fraturadas e depósitos aluvionares que abrange poucos metros de profundidade (atinge até cerca de $30 \mathrm{~m}$ ), mas grande extensão lateral que armazena águas de elevada salinidade. A forte evapotranspiração e transpiração das plantas, aliado as restritas ocorrências de chuva são as causas das altas salinidades nas águas residuais. O sal retido no solo é levado para o aquífero no próximo período de chuvas. As águas do aquífero fraturado que ficam em maiores profundidades são de melhor qualidade segundo o autor.

Silva Junior et al. (1999) relata estudos que mostram que os processos climáticos juntamente com os processos de interação água-rocha nas fraturas atuam de maneira simultânea na salinização das águas de regiões semiáridas. Fraturas pouco profundas $(<40 \mathrm{~m}$ de profundidade) se comunicam com aluviões e permitem maior circulação das águas no aquífero, já nas fraturas mais profundas essa circulação é mais restrita havendo mais tempo de contato água-rocha. No primeiro caso as condições climáticas predominam, já no segundo a interação água-rocha é dominante. Além disso, os autores citam que em análises químicas realizadas em águas em contato com diferentes litologias, não foram observadas variações químicas significativas, sendo que águas provenientes de diversas litologias possuem características químicas semelhantes.

Em estudos realizados na Bacia do Potiguar (principalmente na Formação Açu e no embasamento) não foi possível observar uma correlação significativa entre o conteúdo de sais e a composição isotópica da água subterrânea o que é um indicativo de que os mecanismos de mineralização são independentes dos mecanismos de recarga d'água no nordeste brasileiro. Também foi observado que não existe uma relação entre o tempo de residência das águas subterrâneas (obtidas com isótopos de $\mathrm{O}^{18}, \mathrm{H}^{3}, \mathrm{D}$ e $\mathrm{C}^{14}$ ) e a salinidade destas. Estes resultados apontaram que a origem das águas subterrâneas é independente da origem dos sais. Algumas das 
hipóteses para explicar a origem dos sais seria uma transgressão marinha pretérita e formação dos sais por evaporação intensa ou ainda pela influência dos ventos marinhos no carreamento dos sais (SILVEIRA \& SILVA JUNIOR, 2002).

Andrade \& Leal (2010) realizaram estudos da causa das elevadas salinidades das águas subterrâneas dos aquíferos fraturados na região de Uauá (Bahia). Os autores revelam que dos 115 poços pesquisados somente 7\% apresenta STD (Sólidos Totais Dissolvidos) menores que 1.000 $\mathrm{mg} / \mathrm{L}$. Esses $7 \%$ estão relacionados a presença de diques máficos e anfibolitos altamente metamorfizados com fraturamento denso e aberto. Já as águas com STD maior que $1.000 \mathrm{mg} / \mathrm{L}$ estão relacionadas a metassedimentos (filitos e xistos). Os autores realizaram análises hidroquímicas e de isótopos estáveis nas águas subterrâneas. As águas apresentaram baixa correlação do STD com o íon bicarbonato, porém alta correlação entre o STD e o íon cloreto, indicando fraca associação entre a salinidade das águas e o processo de interação água-rocha. Já os dados de isótopos estáveis $\left(\delta^{18} \mathrm{O}\right.$ e $\left.\delta \mathrm{D}\right)$ mostraram que as águas mais salinas são enriquecidas em isótopos pesados e sofreram forte influência de evaporação, já as águas menos salinas apresentam assinaturas correspondentes a GMWL indicando recarga direta por água da chuva sem interferência da evaporação. Os autores concluem que a participação de fatores climáticos (evaporação) tem um importante papel na salinização das águas subterrâneas na região.

Diversos fatores podem gerar as altas salinidades observadas nas águas subterrâneas do município de Petrolina. O mais provável é que um conjunto de fatores atue de maneira conjunta culminando nas altas condutividades constatadas.

As baixas precipitações observadas no município fazem com que o processo de hidrólise nos solos seja parcial com predominância do processo de bissialitização. Tal fato resulta em solos pouco evoluídos, férteis e ricos em minerais expansivos do tipo 2:1 e 1:1, como cambissolos e vertissolos.

Ferracini et al. (2001) em estudo realizado na região de Petrolina-PE relata que predominam solos arenosos e quartzosos, porém também ocorrem solos podzólicos, latossolos vermelho-escuros, latossolos vermelho-amarelos e vertissolos. As areias quartzosas possuem textura arenosa a franco-arenosa, são praticamente isentas de minerais primários alteráveis e ocorrem da superfície até uma profundidade mínima de $150 \mathrm{~cm}$ ou até o contato lítico. Os vertissolos são solos expansivos que favorecem a ocorrência do processo de lixiviação pelas suas características físicas. Os latossolos são solos destituídos de minerais primários e secundários, muito evoluídos, muito profundos, fortemente ácidos, com média a alta saturação por bases.

Neto et al. (2013) descrevem a ocorrência de argissolos amarelos, planossolos háplicos e neossolos quartzarênicos em área do município de Petrolina. Os pesquisadores citam que acima do embasamento cristalino ocorrem: materiais detríticos e/ou lateríticos de dimensões variadas e coloração amarelada, sedimentos eólicos formados por depósitos de areia bem selecionada e depósitos colúvio-aluvionares formados por materiais de cor e granulometria variados ao longo da margem de rios e riachos.

Os argissolos amarelos plínticos predominam na região estudada, possuem textura média ou arenosa na superfície com incremento de argila em profundidade, são profundos, com presença de zonas mosqueadas ou concreções ferruginosas e/ou cascalhos de quartzo ao longo do perfil. São associados às coberturas sedimentares do Terciário (NETO et al., 2013).

Os planossolos háplicos arênicos possuem textura média ou arenosa em superfície com forte incremento de argila em profundidade, tem cor esbranquiçada com mosqueamentos avermelhados devido à encharcamento constantes durante as chuvas. Apresentam um horizonte 
denso com presença de sais devido à influência da rocha sã e são comuns nas áreas de relevo plano associados a granitos e gnaisses (NETO et al., 2013).

Os neossolos quartzarênicos típicos também possuem textura arenosa, são profundos, bastante uniformes e constituídos por quartzo bem selecionado, possuem alta permeabilidade e estão ligados aos sedimentos eólicos presentes na região (NETO et al., 2013).

Além dos solos descritos por Neto et al. (2013) foram observados durante os trabalhos de campo Neossolo Litólico, Vertissolo Háplico, Cambissolo Háplico, e subordinadamente Latossolo Vermelho Amarelo. Os solos de forma geral apresentam elevado grau de eutrofismo e enriquecimento em íons devido ao clima semiárido.

Dessa maneira, os solos da região de Petrolina, em sua maioria, sofreram pouca influência do processo de lixiviação e por isso são pouco evoluídos, atingem pequenas profundidades e são ricos em elementos alcalinos e alcalinos terrosos. As águas das precipitações percolam pelos solos sobre o substrato cristalino impermeável até encontrarem uma fratura onde são infiltradas. Durante esse processo estas podem carrear elementos solúveis dos argilominerais presentes nos solos, além de sofrer evaporação devido à alta radiação solar. Tais processos podem enriquecer as águas em íons aumentando sua salinidade antes destas percolarem pelas fraturas das rochas.

O clima da região também é um fator importante no enriquecimento das águas em sais. As baixas taxas de precipitação observadas, juntamente com as altas temperaturas e irradiações solares existentes e as altas taxas de evapotranspiração, limitam a recarga dos aquíferos fraturados dos terrenos cristalinos.

O relevo plano do município aliado aos terrenos cristalinos impermeáveis e aos solos pouco espessos faz com que as águas das precipitações permaneçam por períodos prolongados na superfície do terreno onde a evaporação faz com que as águas residuais fiquem enriquecidas em sais. Posteriormente, novas chuvas podem carrear os sais acumulados por essas águas residuais para dentro dos aquíferos fraturados.

Outro fator relevante são as características das fraturas da região que possuem baixa conectividade. Juntamente com o relevo plano, esses são fatores que restringem a circulação de água no aquífero. O prolongado tempo de permanências das águas nas fraturas faz com que a interação entre água-rocha seja significativa podendo contribuir com as altas salinidades.

Acredita-se que as altas quantidades de sais detectadas nas águas subterrâneas dos aquíferos fraturados do município de Petrolina possam ser resultado da ação conjunta de fatores e não ser causada por um aspecto isoladamente. Os principais fatores são:

- Fatores climáticos (elevada temperatura, alta taxa de evaporação e irradiação solar intensa aliado a chuvas escassas e irregulares espacial e temporalmente);

- Recarga restrita;

- Características dos solos (pouco lixiviado, ricos em elementos alcalinos e alcalinos terrosos, pouco espessos e predominantemente arenosos e quartzosos);

- Relevo suave ondulado a plano;

- Característica das fraturas (baixa conectividade);

- Processo de interação água-rocha.

O uso de sistemas de recarga artificial para solução de problemas relacionados à escassez hídrica em regiões áridas e semiáridas é descrito na literatura. Harpaz \& Bear (1964) relata que 
principalmente em regiões áridas a ocorrência de reservatórios superficiais consideráveis é raro devido a forte evaporação. Nesses locais os aquíferos tem grande capacidade de armazenamento de excedentes de água e podem ser utilizados como reservatórios de água recarregados nos períodos úmidos para garantir o abastecimento nos períodos secos. Os autores também citam que nessas áreas ocorrem aquíferos próximos com águas de diferentes salinidades. $\mathrm{O}$ processo de mistura dessas águas pode melhorar a qualidade ampliando suas possibilidades de uso. 


\section{CAPÍTULO 4}

\section{RESULTADOS}

$\mathrm{Na}$ presente dissertação de mestrado, foram realizadas análises em amostras de água subterrânea, superficial e de rocha, ambas coletadas no município de Petrolina-PE. Trabalhos de campo foram realizados em 10/2013, 12/2014, 03/2015 e 09/2015. As análises foram realizadas tanto em laboratórios da Universidade de Brasília (UnB) quanto em laboratórios internacionais. Também foram utilizados dados disponibilizados pelo projeto RECARFRAT, que foram coletados em etapas anteriores.

Os locais das diversas amostragens estão espacializados na Figura 4.1 e serão descritos a seguir. Os dados brutos estão disponíveis em anexo ao final da dissertação.
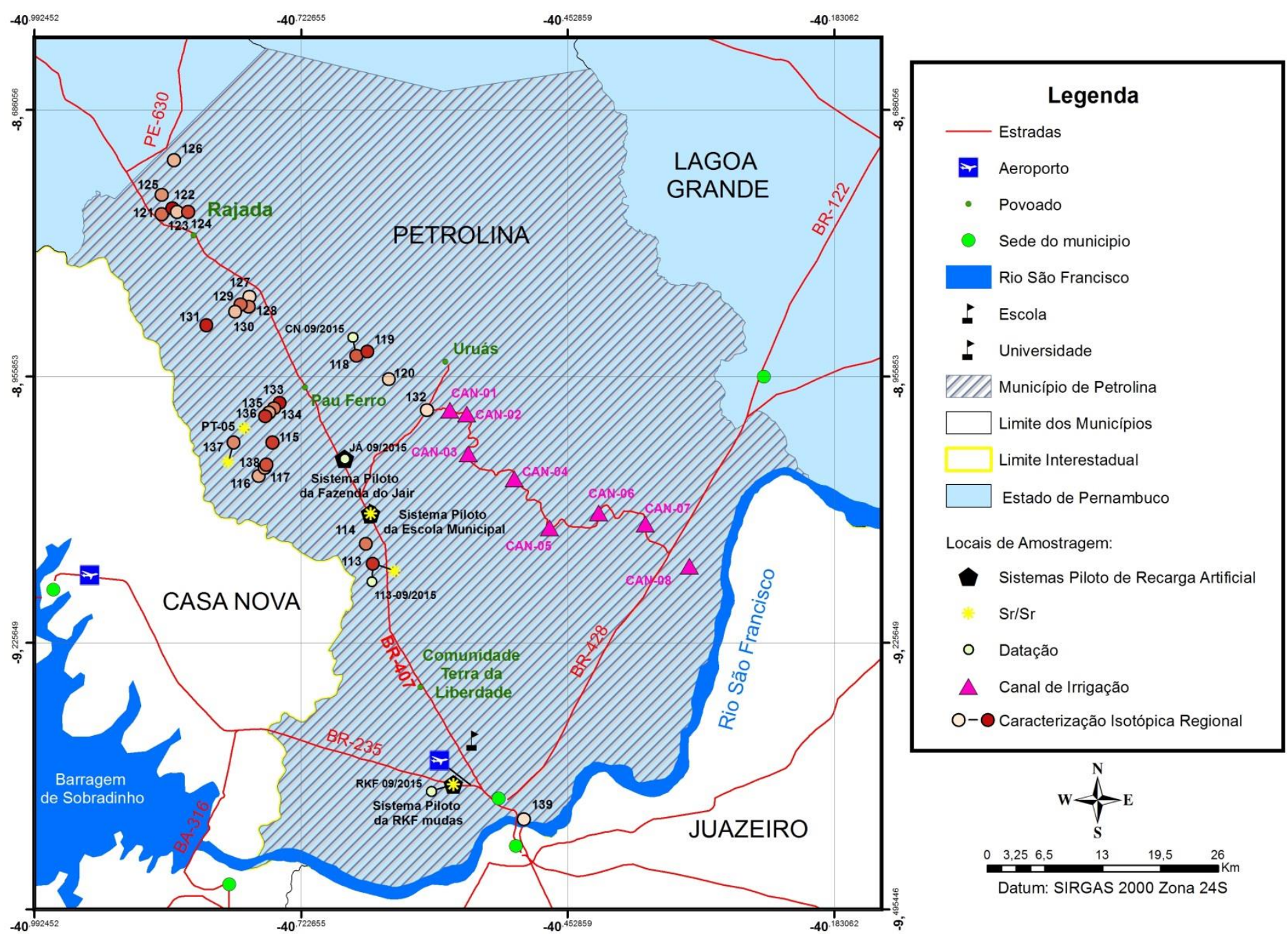

Figura 4.1 - Mapa de localização das amostragens realizadas em águas superficiais, subterrâneas e em rocha no município de Petrolina-PE. A escala de tons de vermelho nos sítios de amostragem para caracterização isotópica regional se referem à condutividade elétrica (C.E.) das águas. Quanto mais forte o vermelho, maiores as C.E. 


\subsection{Hidroquímica}

A análise hidroquímica completa de 526 poços foi cedida pelo projeto RECARFRAT como dados preliminares para a presente dissertação. As análises foram realizadas entre os anos de 2001 e 2002, por um casal de pesquisadores alemães, em poços do município o que resultou em uma Carta Geohidroquímica do Município de Petrolina na escala 1:100.000 (Figura 4.2). Os poços coletados estavam alocados tanto em rochas do Cráton São Francisco quanto da Faixa Móvel Riacho do Pontal.

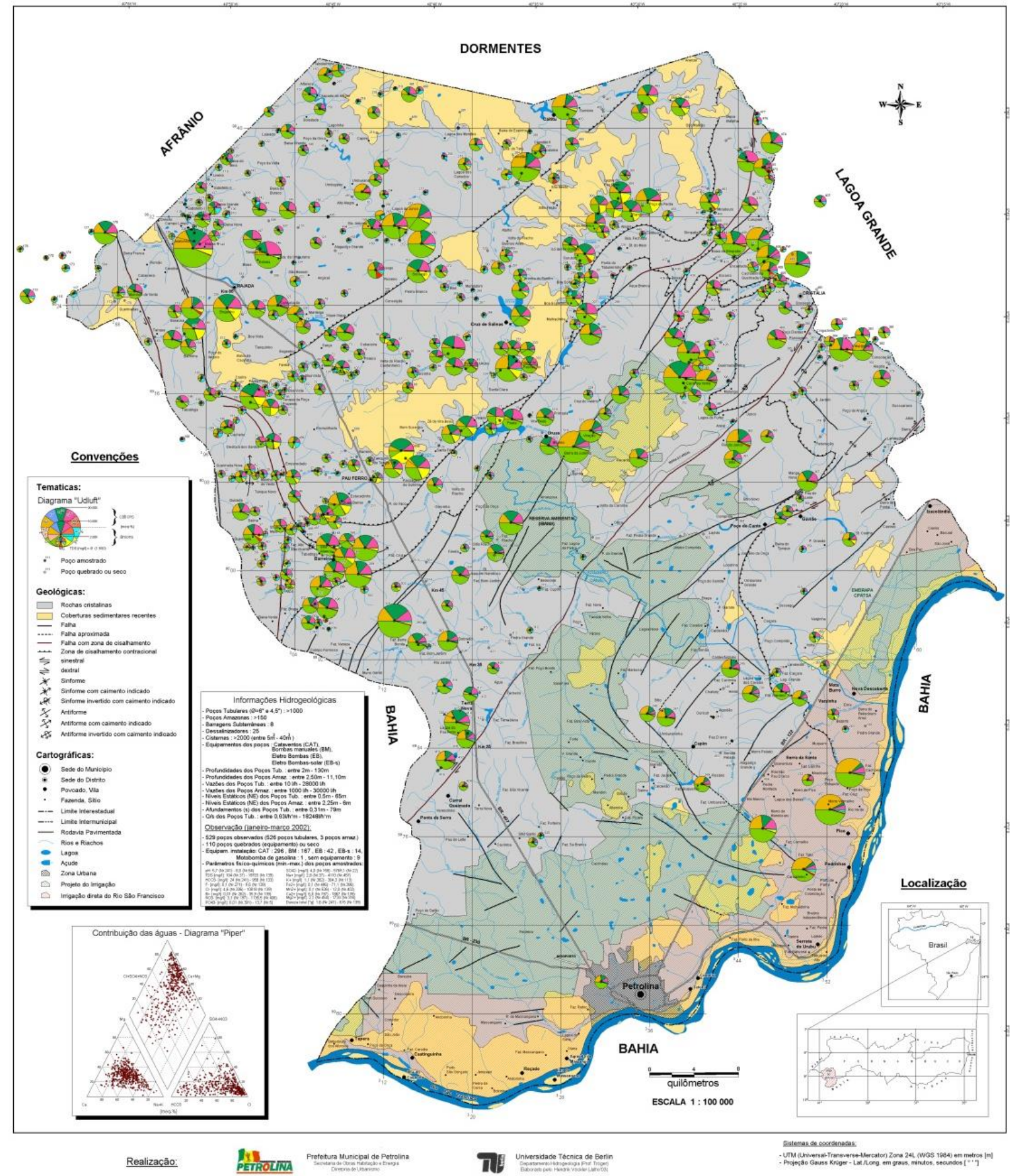

Figura 4.2 - Carta Geohidroquímica do Município de Petrolina na escala 1:100.000 elaborada com base na análise hidroquímica de 526 amostras de água subterrânea realizada em 2001/2002. 
Durante os trabalhos de campo desenvolvidos posteriormente, foram coletadas novas amostras para análise hidroquímica a título de comparação com as já existentes. Porém, dificuldades foram encontradas no armazenamento das amostras, decorrente do alto teor de íons dissolvidos; e nas instalações do Laboratório de Geoquímica da UnB devido a uma enchente que acometeu a universidade. Assim, foi decidido fazer uma análise mais detalhada dos dados analisados em 2001/2002 disponibilizados pelo projeto RECARFRAT.

As análises incluíam os íons: $\mathrm{HCO}_{3}{ }^{-}, \mathrm{F}^{-}, \mathrm{Cl}^{-}, \mathrm{Br}^{-}, \mathrm{NO}_{3}{ }^{-}, \mathrm{PO}_{4}{ }^{3-}, \mathrm{SO}_{4}{ }^{2-}, \mathrm{Na}^{+}, \mathrm{K}^{+}, \mathrm{Fe}^{2+}, \mathrm{Mn}^{2+}$, $\mathrm{Ca}^{2+}$ e $\mathrm{Mg}^{2+}$ e os parâmetros $\mathrm{pH}$, condutividade elétrica (CE) e Sólidos Totais Dissolvidos (TDS).

Realizou-se então o cálculo do balanço iônico pelo software gratuito QUALIGRAPH. Através do erro prático (Ep) calculado pelas fórmulas de Logan (1965) e Custódio e Llamas (1983), o balanço iônico foi classificado em "Bom" (Ep abaixo do erro máximo permitido) ou "Ruim" (Ep acima do erro máximo permitido) separadamente de acordo com os dois autores. No total, 232 amostras foram classificadas como "Bom" por ambos os autores. Estas foram selecionadas. Elas foram plotadas no Diagrama de Piper (Figura 4.3) e a classificação das mesmas no referido diagrama encontra-se representada na Figura 4.4. A maioria das amostras $(39,2 \%)$ foi classificada como mistas cloretadas.

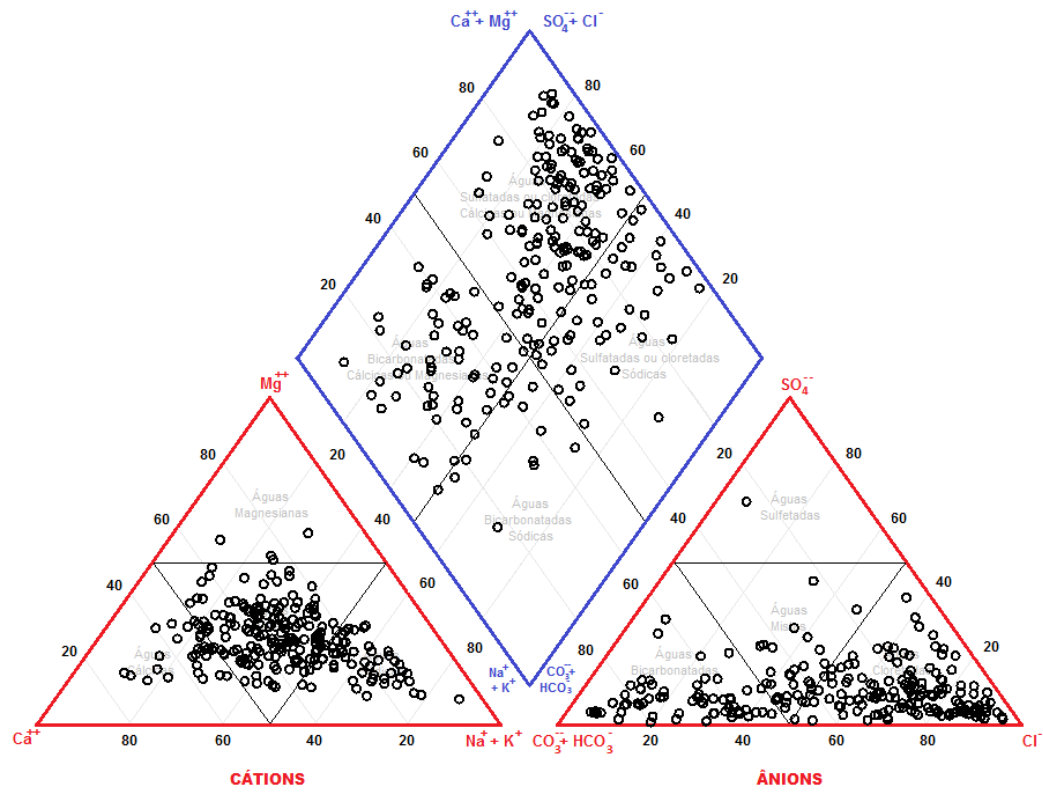

Figura 4.3 - Diagrama de Piper com as 232 amostras selecionadas pela avaliação do balanço iônico.
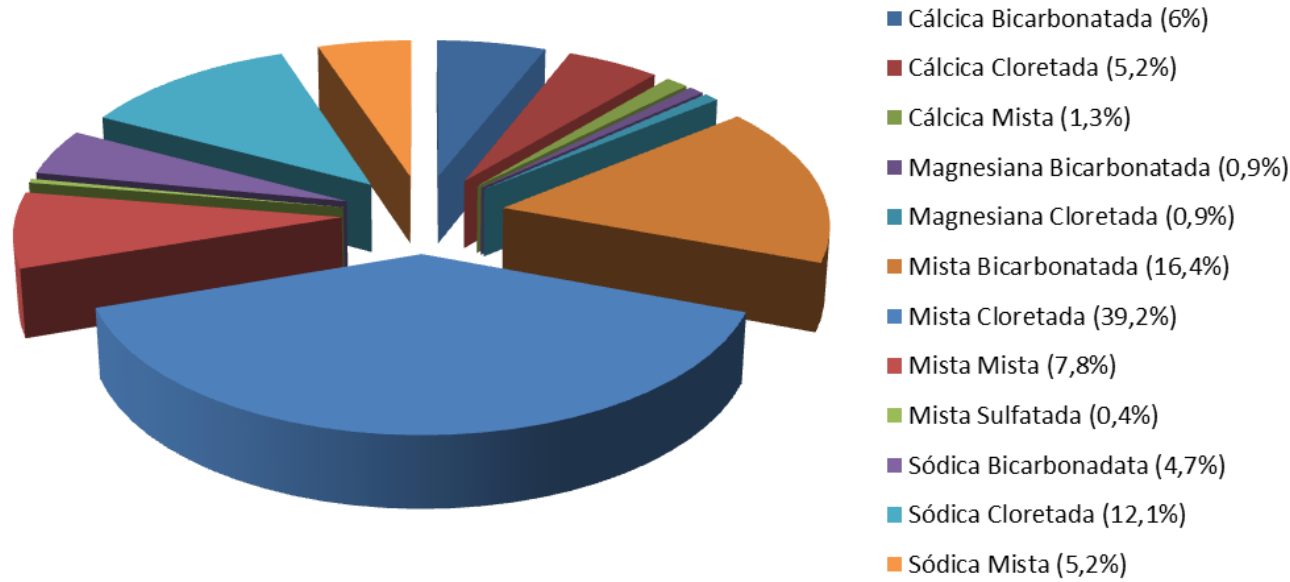

Figura 4.4 - Classificação das 232 amostras selecionadas de água subterrânea do município de Petrolina segundo o Diagrama de Piper. 
Após a classificação geral, as amostras foram divididas em grupos conforme as suas condutividades elétricas (Tabela 4.1), objetivando analisar possíveis variações na composição hidroquímica das águas de diferentes salinidades.

Tabela 4.1 - Características dos grupos separados para análise hidroquímica.

\begin{tabular}{|c|c|c|}
\hline \multirow{2}{*}{ GRUPO } & $\begin{array}{c}\text { INTERVALO DE } \\
\text { CONDUTIVIDADE ELÉTRICA }\end{array}$ & $\begin{array}{c}\text { NÚMERO DE } \\
\text { AMOSTRAS }\end{array}$ \\
\hline 1 & $100 \mu \mathrm{S} / \mathrm{cm}-500 \mu \mathrm{S} / \mathrm{cm}$ & 19 \\
\hline 2 & $500 \mu \mathrm{S} / \mathrm{cm}-1.000 \mu \mathrm{S} / \mathrm{cm}$ & 47 \\
\hline 3 & $1.000 \mu \mathrm{S} / \mathrm{cm}-2.000 \mu \mathrm{S} / \mathrm{cm}$ & 55 \\
\hline 4 & $2.000 \mu \mathrm{S} / \mathrm{cm}-4.000 \mu \mathrm{S} / \mathrm{cm}$ & 55 \\
\hline 5 & $4.000 \mu \mathrm{S} / \mathrm{cm}-5.000 \mu \mathrm{S} / \mathrm{cm}$ & 32 \\
\hline 6 & $5.000 \mu \mathrm{S} / \mathrm{cm}-10.000 \mu \mathrm{S} / \mathrm{cm}$ & 9 \\
\hline 7 & $10.000 \mu \mathrm{S} / \mathrm{cm}-20.000 \mu \mathrm{S} / \mathrm{cm}$ & 1 \\
\hline 8 & $20.000 \mu \mathrm{S} / \mathrm{cm}-30.000 \mu \mathrm{S} / \mathrm{cm}$ & \\
\hline
\end{tabular}

Na Figura 4.5, os grupos de amostras foram plotados no Diagrama de Piper. Uma amostra representativa de cada grupo foi escolhida e a porcentagem correspondente a cada íon nessa amostra foi calculada. Esses valores foram representados através de "gráficos de pizza".

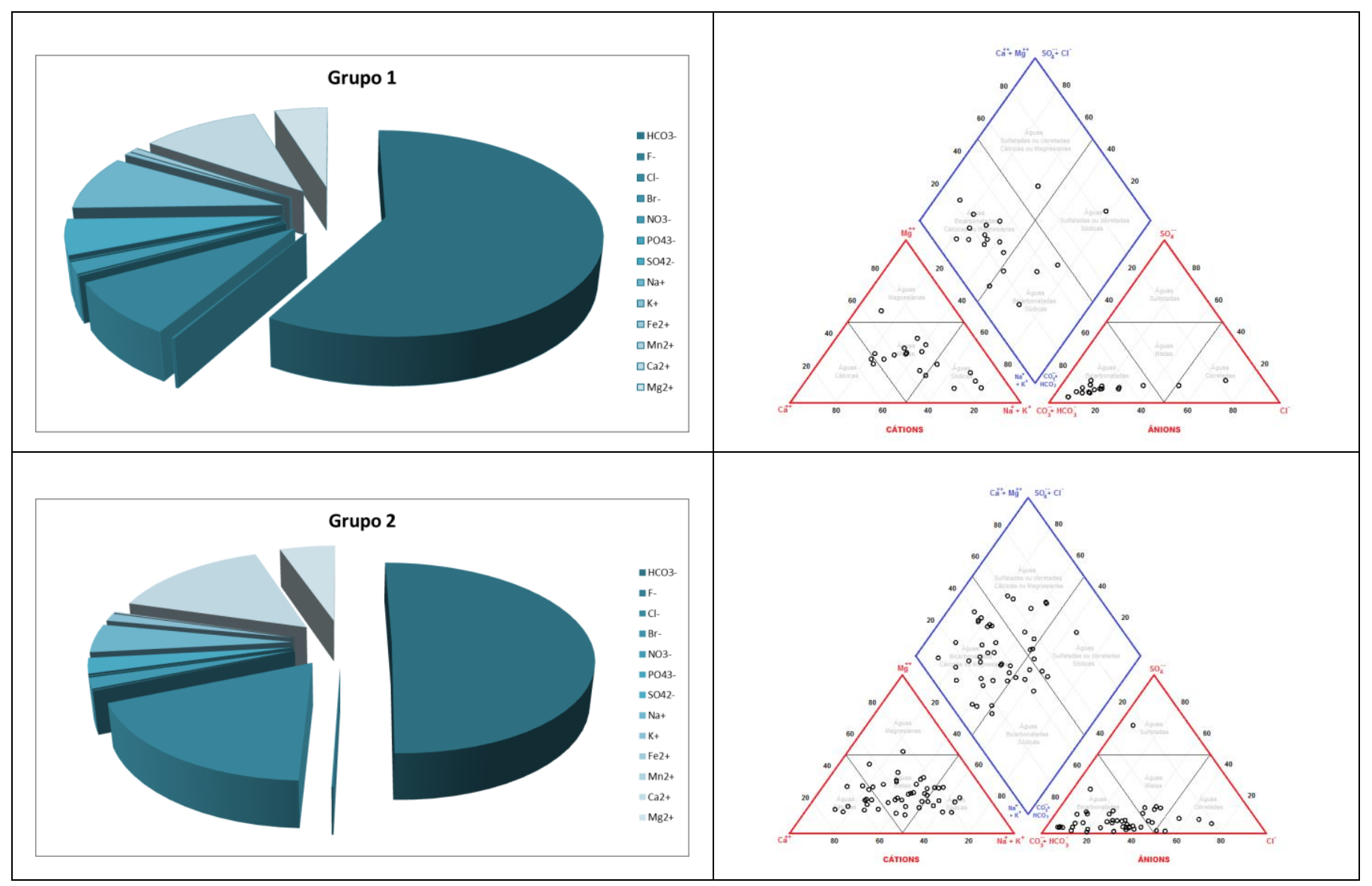




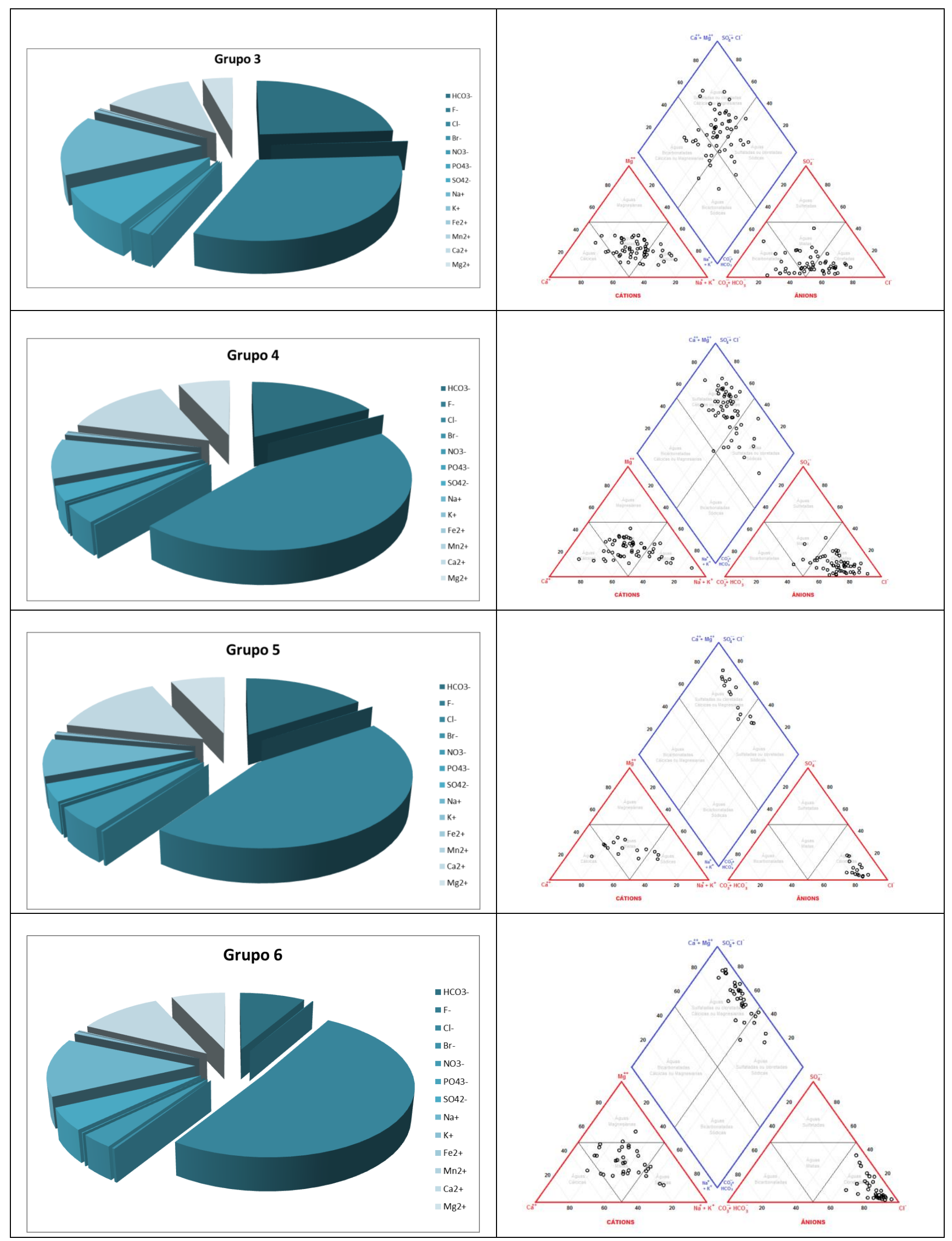




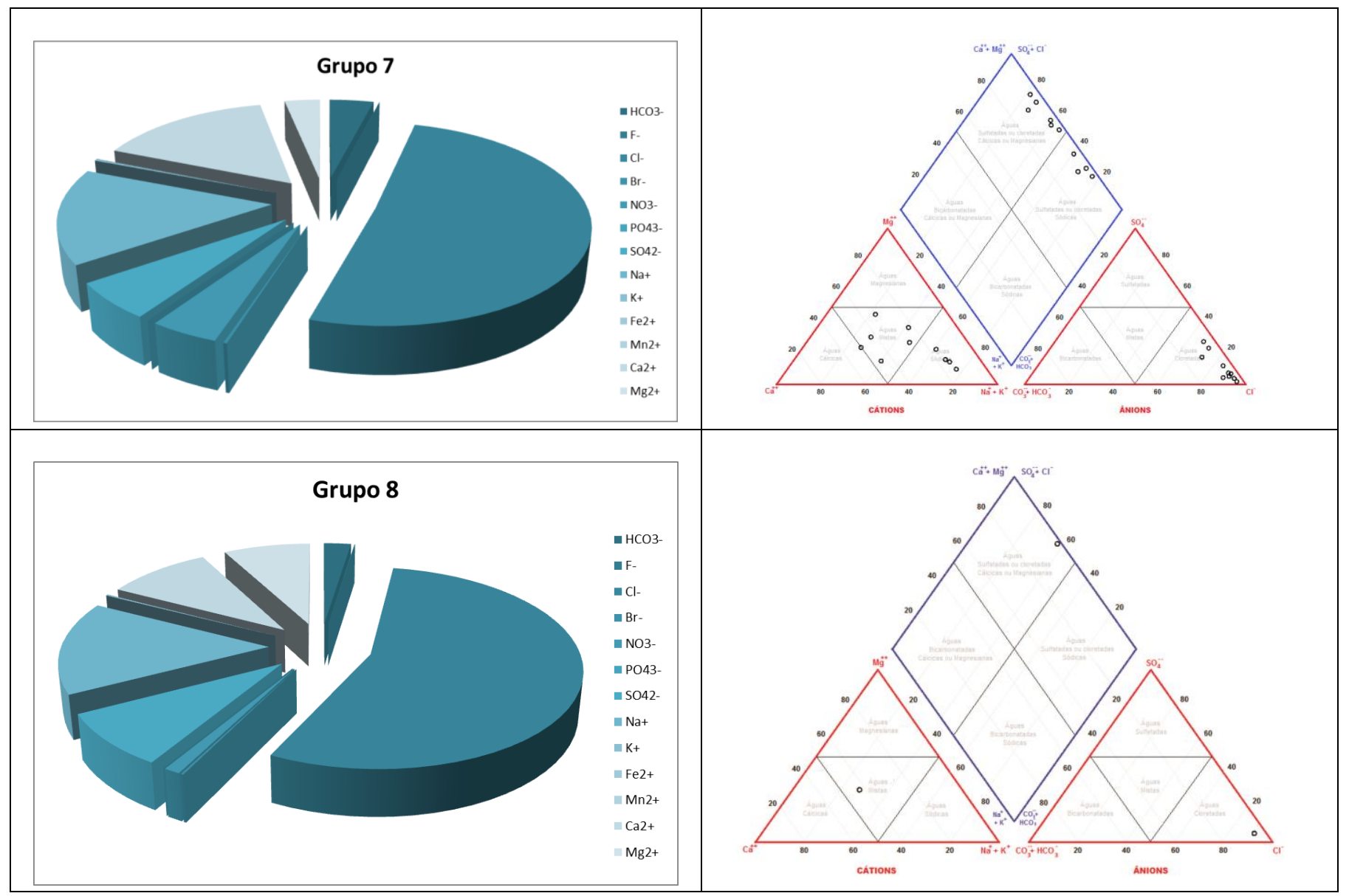

Figura 4.5 - Gráficos de pizza representando a porcentagem correspondente a cada íon em uma amostra representativa de cada grupo e o Diagrama de Piper por grupo.

$\mathrm{Na}$ análise dos gráficos é possível observar que as águas com menores condutividades elétricas, do grupo 1, são enriquecidas em bicarbonato e são classificadas principalmente como: águas bicarbonatadas cálcicas ou magnesianas e águas bicarbonatadas sódicas. Os grupos 2 e 3 mostram caráter intermediário e apresentam teores equivalentes de cloro e bicarbonato. A partir do grupo 4, as amostras apresentam um enriquecimento em cloro e o bicarbonato diminui significativamente. São classificadas como: águas sulfatadas ou cloretadas cálcicas ou magnesianas e águas sulfatadas ou cloretadas sódicas (Figura 4.6).

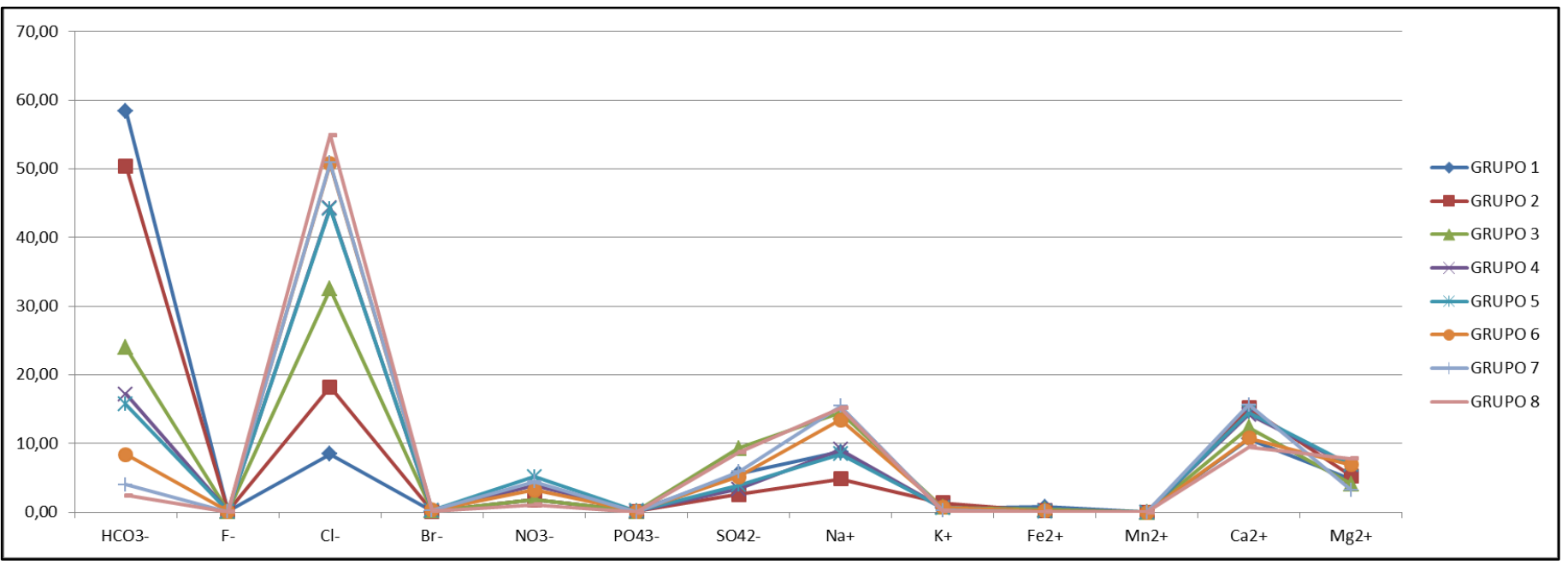

Figura 4.6 - Concentração dos íons das amostras representativas de cada grupo. 
Foram elaborados também gráficos dos principais elementos químicos versus as condutividades elétricas das 232 amostras selecionadas pelo balanço iônico do grupo total das 526 análises dos poços realizados pelos pesquisadores alemães em 2001/2002 (Figura 4.7). Os íons que apresentam as maiores correlações com a condutividade são: flúor, fosfato, sódio, cálcio e magnésio, mas principalmente cloro e bromo. Portanto, esses são os íons que contribuem de maneira mais significativa para as altas condutividades elétricas observadas.
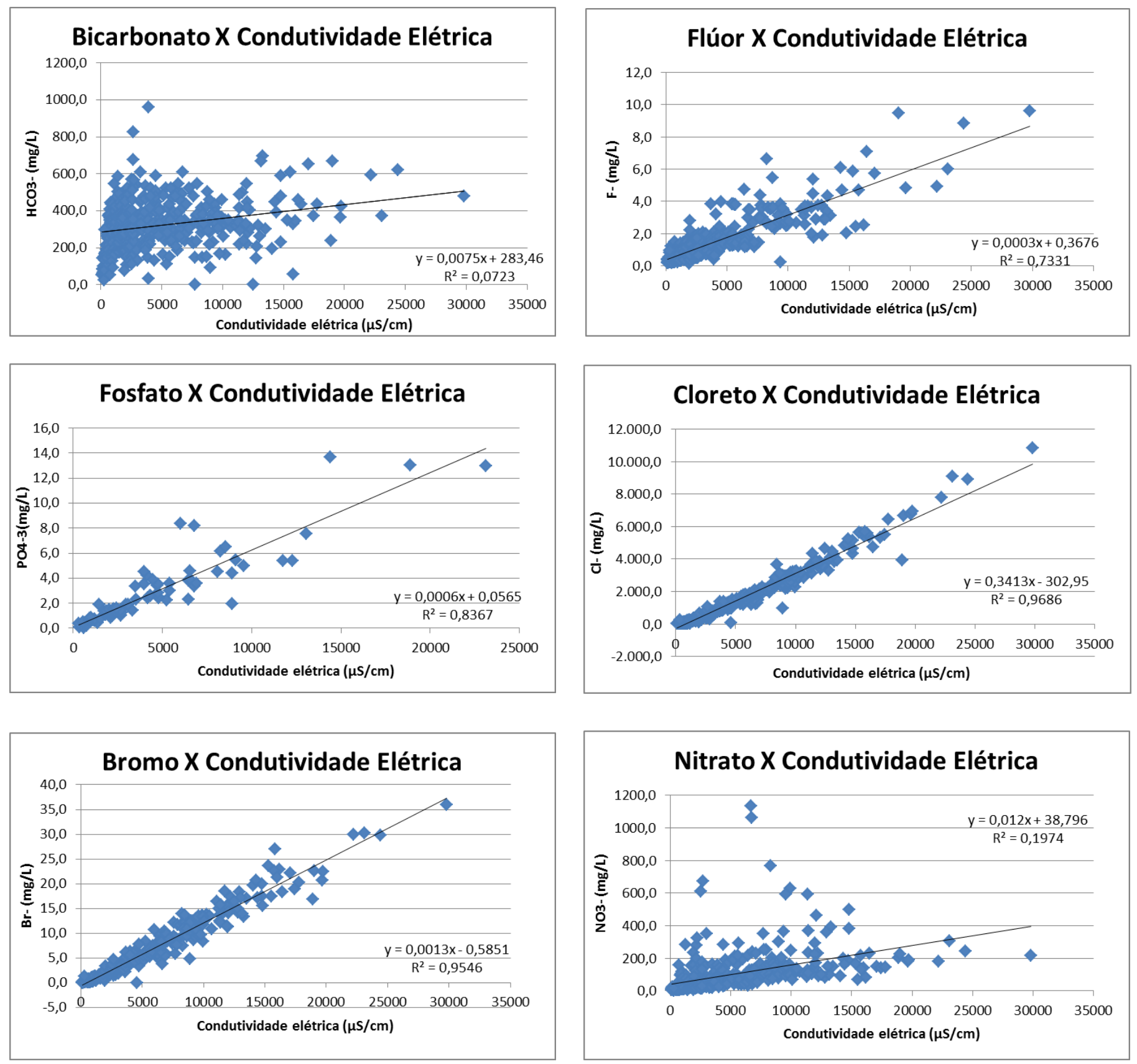

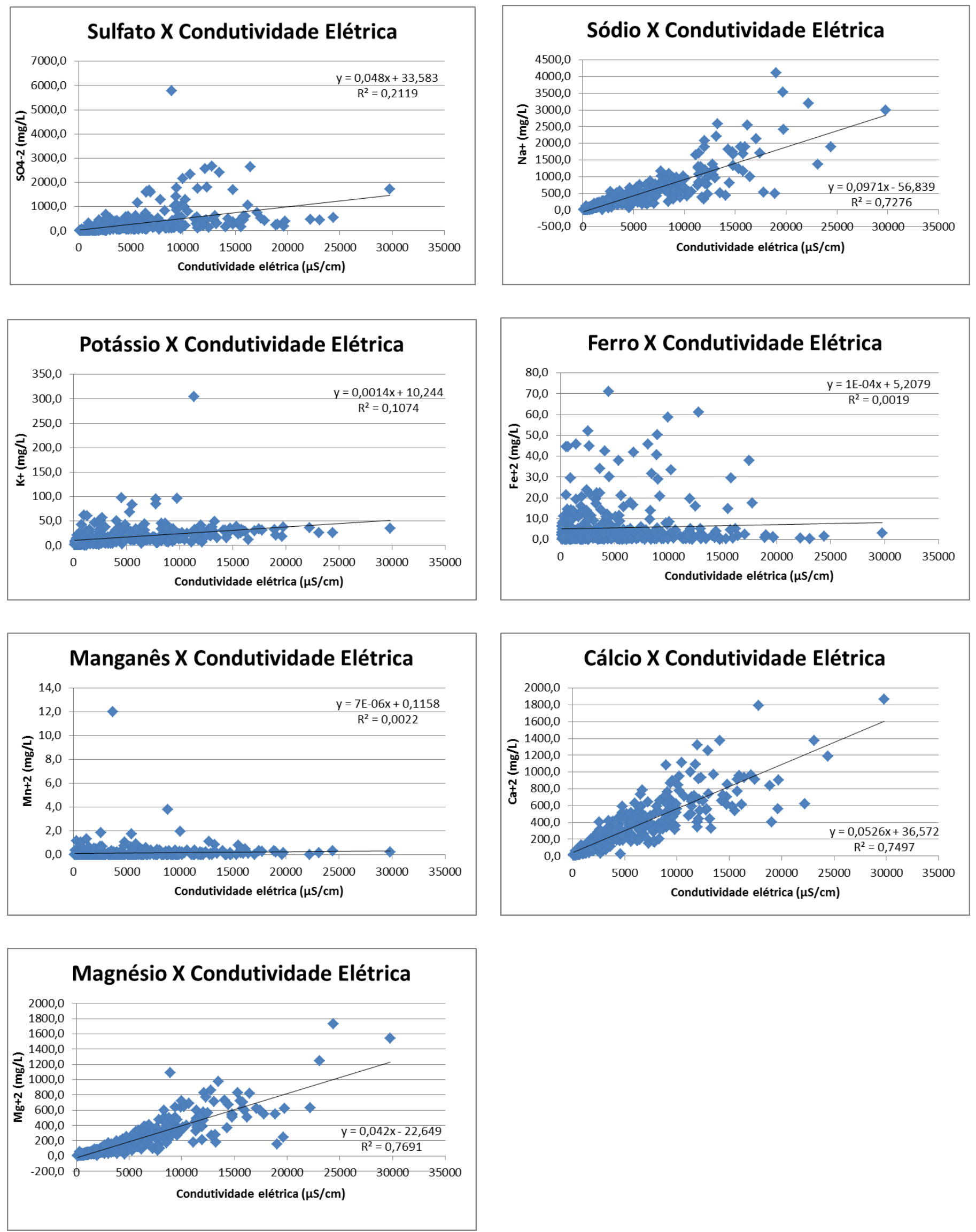

Figura 4.7 - Gráficos que relacionam a concentração dos principais íons com as condutividades elétricas para poços de Petrolina-PE. 


\subsection{Isótopos Estáveis}

O presente estudo realizou análises dos isótopos estáveis de oxigênio, hidrogênio e estrôncio em amostras de água subterrânea, superficial e rocha coletadas em 2013, 2014 e 2015.

As análises foram realizadas no Laboratório de Geocronologia da Universidade de Brasília, sendo que as de $\delta \mathrm{D}$ e $\delta^{18} \mathrm{O}$ em água foram aferidas no aparelho da marca PICARRO modelo L2120- $i \delta \mathrm{D}$ e $\delta^{18} \mathrm{O}$ Analyzer (adquirido pelo Projeto RECARFRAT) que utiliza o método de medição de espectrometria de massa com separação a laser; e as de ${ }^{87} \mathrm{Sr} /{ }^{86} \mathrm{Sr}$ em água e em rocha foram realizadas no espectrômetro TIMS (espectrômetro de massa por ionização térmica) do modelo Triton Plus.

Primeiramente, em outubro de 2013, foram realizadas análises de $\delta \mathrm{D}$ e $\delta^{18} \mathrm{O}$ em 24 amostras de poços distribuídos pelo município e com condutividades elétricas variadas a fim de se estabelecer uma caracterização isotópica regional das águas subterrâneas. Os pontos de coleta foram escolhidos com base no acervo de 526 poços elaborado no estudo hidroquímico realizado anteriormente nos anos de 2001 e 2002. As localizações dos pontos de coleta estão dispostas na Figura 4.1. Dos 24 poços 2 estão localizados nas rochas do Cráton São Francisco e 22 em rochas da Faixa Móvel Riacho do Pontal.

Os dados coletados foram plotados no gráfico $\delta \mathrm{D}$ versus $\delta^{18} \mathrm{O}$ e comparados com a curva da água meteórica global (GMWL) e com curvas de águas meteóricas locais (LMWL). Os dados das curvas de águas meteóricas locais são correspondentes a estações da IAEA localizadas no nordeste brasileiro; e a estudos elaborados por Silveira \& Silva Junior (2002). Os dados do IAEA foram retirados do programa denominado Global Network of Isotopes in Precipitation (GNIP) e estão disponíveis no site: http://www-naweb.iaea.org/napc/ih/IHS_resources_gnip.html.

As estações do IAEA escolhidas foram: Betânia, Betânia - Fazenda CONCEICAP, Floresta, Salvador e Serra Talhada. A outra LMWL foi à obtida por Silveira \& Silva Junior (2002) que elaboraram uma reta da água meteórica local para a região nordeste, obtida com várias estações da área. A equação da reta segundo os autores é:

$$
\delta D=10( \pm 2)+8,2( \pm 0,8) \delta^{18} O
$$

Os pontos de Petrolina estão plotados juntamente com a curva da GMWL e as curvas de LMWL na Figura 4.8. Além das amostras de água subterrânea também foram plotadas no gráfico, amostras de água da chuva, do canal de irrigação e do Rio São Francisco.

A coleta no canal de irrigação foi realizada no local onde os caminhões pipa se abastecem próximo a Uruás, já a coleta no Rio São Francisco foi realizada na praia da sede do município de Petrolina, a jusante da ponte que une Petrolina e Juazeiro. As amostras de água da chuva foram coletadas em 21/03/2015 após chuva branda e em 23/03/2015 após chuva forte que durou quase toda a madrugada do dia anterior. 


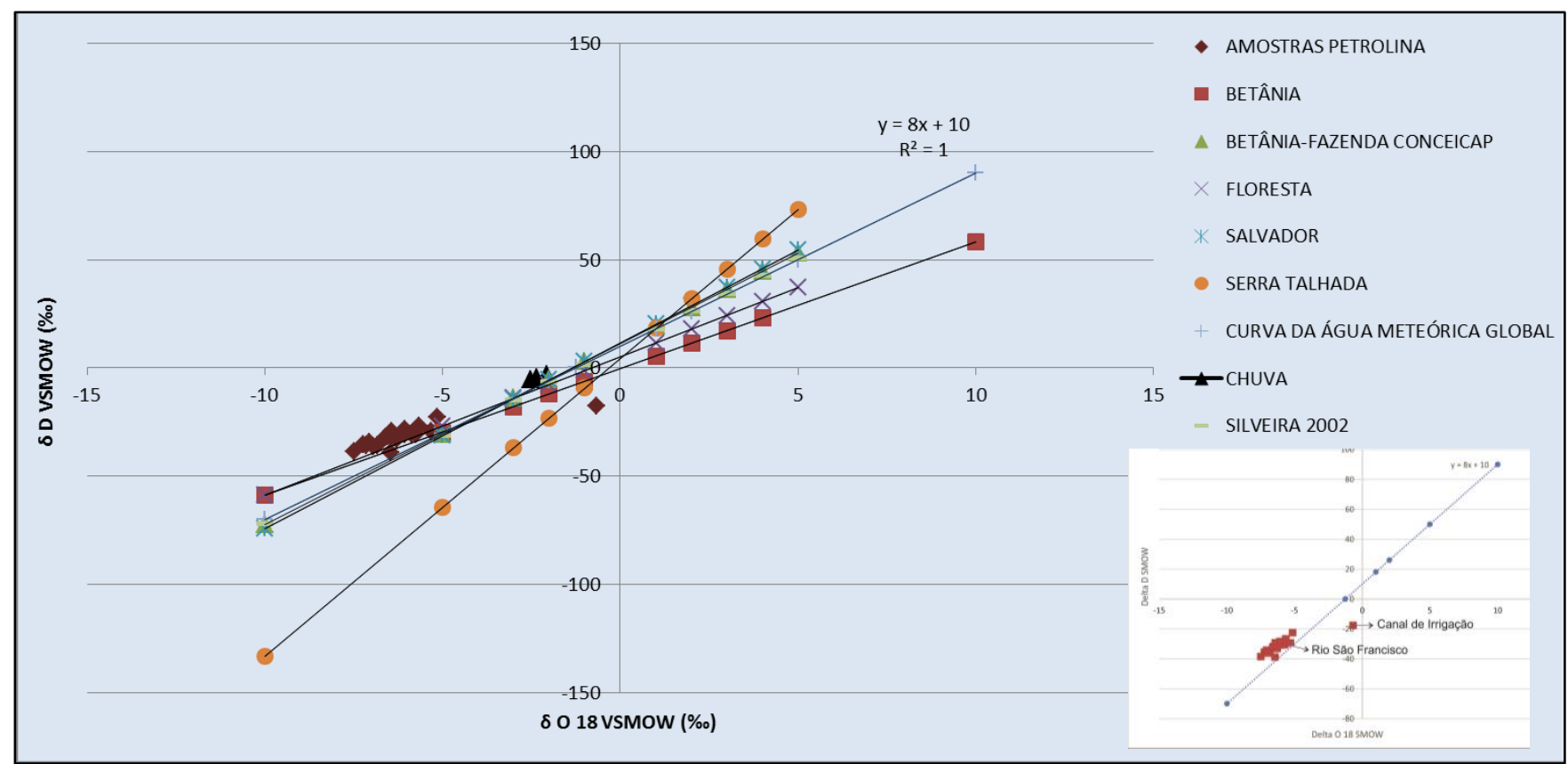

Figura 4.8 - Gráfico $\delta D$ versus $\delta^{18} O$ com a representação das amostras de água subterrânea e superficial (canal de irrigação, Rio São Francisco e amostras de chuva) coletadas no município de Petrolina-PE em relação a GMWL e LMWL. No quadro a direita é possível observar a indicação das amostras coletadas no canal de irrigação e no Rio São Francisco.

Conforme previsto, as amostras de chuva e do Rio São Francisco se localizam sobre a linha da GMWL; e a do canal de irrigação se localiza a direita da curva mostrando a influência da evaporação. Porém, as amostras de água subterrânea se localizam acima das curvas de GMWL e LMWL o que foi observado poucas vezes na literatura.

Em dezembro de 2014, uma amostragem também foi feita ao logo do canal de irrigação que sai do Rio São Francisco e chega até o povoado de Uruás. Foram coletadas 8 amostras para análise de $\delta \mathrm{D}$ e $\delta^{18} \mathrm{O}$ distribuídas pelo canal. O canal é utilizado para irrigação e para abastecimento de carros pipa que levam água para encher cisternas e abastecer as famílias do interior do município. Por esse motivo, existe uma estrada que acompanha o canal por toda sua extensão. O canal possui seções separadas que são limpas periodicamente para retiradas das algas que se formam no fundo e nas paredes.

A Figura 4.9 apresenta fotos retiradas durante as coletas no canal de irrigação. Já a Figura 4.10 representa os resultados das análises isotópicas das amostras do canal. Os resultados mostram nitidamente a curva de evaporação da água no canal de irrigação, evidenciando a importância desse processo no balanço hídrico do semiárido nordestino. 


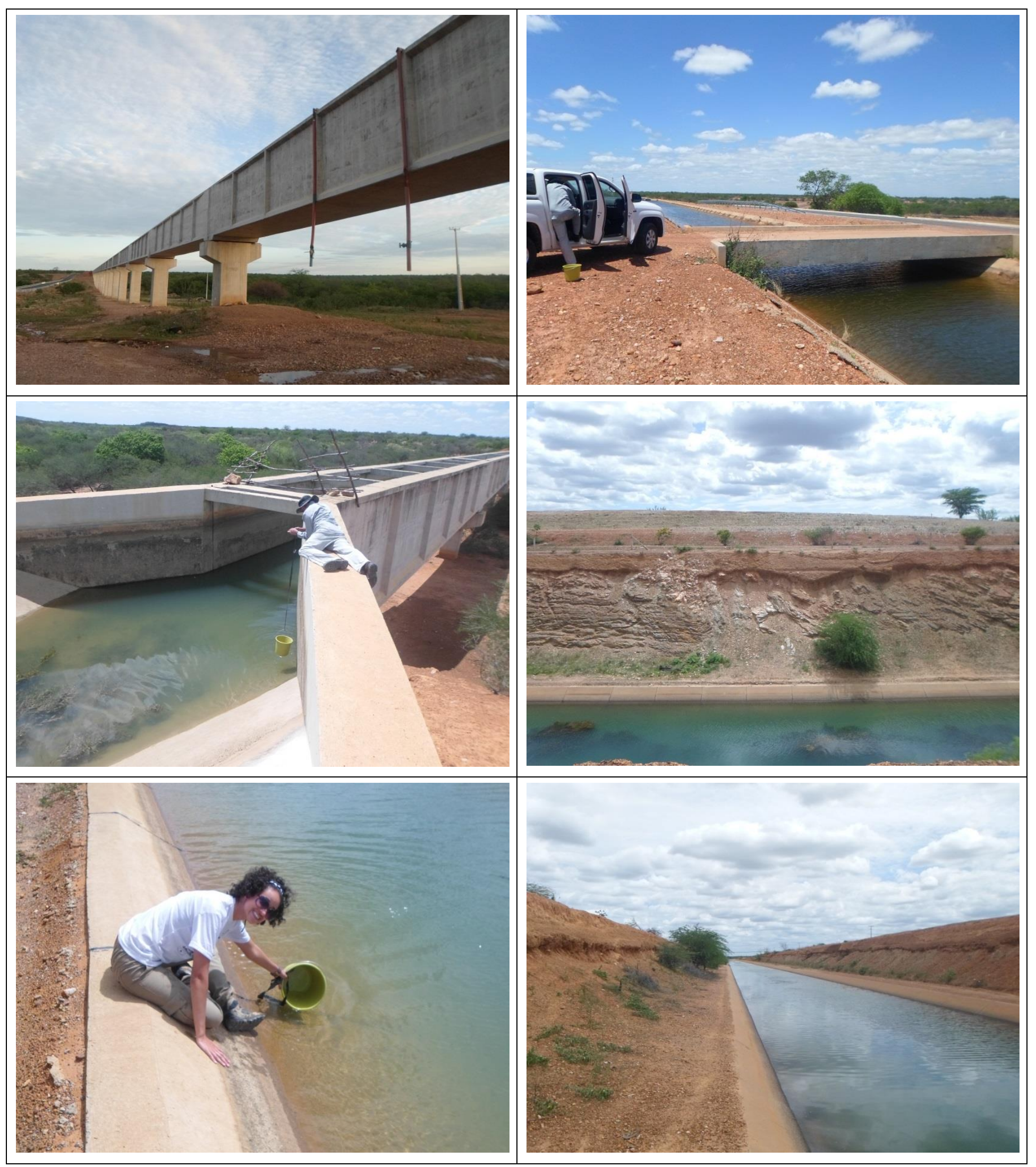

Figura 4.9 - Fotos das coletas ao longo do canal de irrigação no município de Petrolina - PE. 


\section{Amostragem no canal de irrigação - Município de Petrolina-PE}
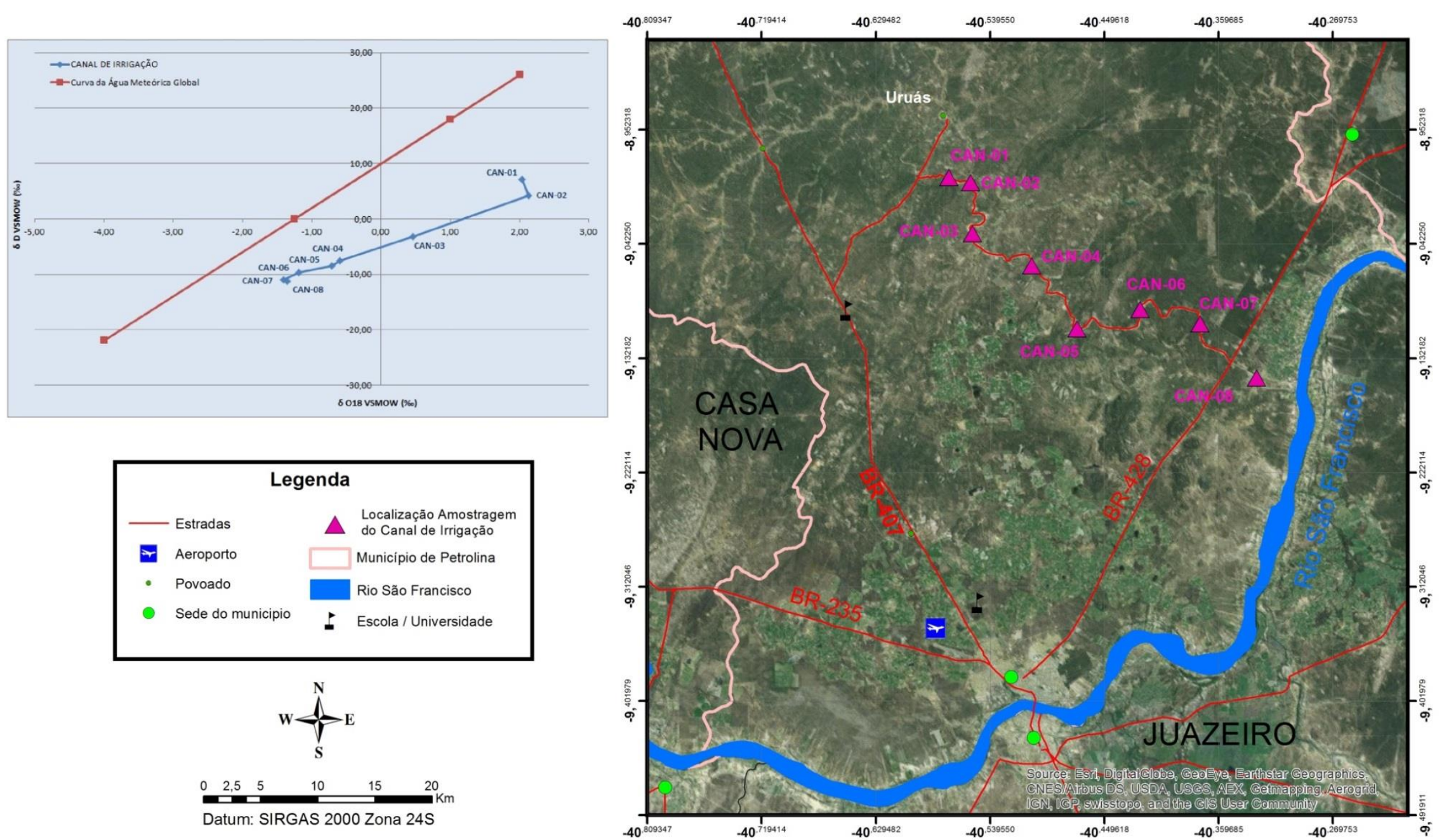

Figura 4.10 - Resultado das análises isotópicas realizadas nas amostras do canal de irrigação, evidenciando a alta taxa de evaporação presente na região semiárida do nordeste brasileiro. 
Análises da razão ${ }^{87} \mathrm{Sr} /{ }^{86} \mathrm{Sr}$ foram realizadas em 5 conjuntos de amostras expressos na Tabela 4.2. Cada conjunto de amostra é composto por uma amostra de água subterrânea coletada em poço tubular e amostras de rocha coletadas próximo ao referido poço tubular. As amostras de rocha são tanto de rochas alteradas (com indícios de alterações nos feldspatos e micas principalmente) correspondentes na Tabela 4.2 a coluna de ${ }^{687} \mathrm{Sr} /{ }^{86} \mathrm{Sr}$ em pó de rocha", quanto de rochas frescas correspondente na Tabela 4.2 a coluna ${ }^{687} \mathrm{Sr} /{ }^{86} \mathrm{Sr}$ em rocha". Os conjuntos de amostras foram coletados em março de 2015. A localização das amostragens está exposta na Figura 4.1. As amostras foram coletas em poços de diferentes condutividades elétricas a fim de se estudar o fenômeno da interação água-rocha nos aquíferos fraturados da região semiárida do nordeste brasileiro. As amostras 113, EM e RKF estão localizadas no Cráton São Francisco; já as amostras PT-05 e 137, na Faixa Móvel Riacho do Pontal.

Os resultados das análises estão expressos na Tabela 4.2.

Tabela 4.2 - Resultado das análises de ${ }^{87} \mathrm{Sr} /{ }^{86} \mathrm{Sr}$ em amostras de água subterrânea e rocha coletadas no município de Petrolina-PE.

\begin{tabular}{|c|c|c|c|c|l|}
\hline Amostra & $\begin{array}{c}{ }^{87} \mathrm{Sr} /{ }^{86} \mathrm{Sr} \\
\text { em água }\end{array}$ & $\begin{array}{c}{ }^{87} \mathrm{Sr}{ }^{86} \mathrm{Sr} \\
\text { em pó de } \\
\text { rocha }\end{array}$ & $\begin{array}{c}{ }^{87} \mathrm{Sr} /{ }^{86} \mathrm{Sr} \\
\text { em rocha }\end{array}$ & $\begin{array}{c}\text { Condutividade } \\
\text { Elétrica } \\
(\mathbf{m S} / \mathbf{c m})\end{array}$ & \multicolumn{1}{|c|}{ Observação } \\
\hline 113 & $0,75155 \pm 1$ & & & 6,28 & \\
\hline EM & $<$ LQ & $0,74111 \pm 1$ & & 9,59 & $\begin{array}{l}\text { Poço do Sistema Piloto da Escola } \\
\text { Municipal }\end{array}$ \\
\hline RKF & $0,74216 \pm 1$ & $0,74153 \pm 1$ & $0,76611 \pm 1$ & 21,44 & $\begin{array}{l}\text { Poço do Sistema Piloto da RKF } \\
\text { Mudas }\end{array}$ \\
\hline PT-05 & & & $0,70751 \pm 1$ & & $\begin{array}{l}\text { Afloramento de rocha de } \\
\text { mármore bandado }\end{array}$ \\
\hline 137 & $0,71989 \pm 1$ & $0,71360 \pm 1$ & & 2,92 & \\
\hline
\end{tabular}

\subsection{Datação}

Foram realizadas datações pelo método do Carbono 14 e pelo método do Trítio em 4 amostras de água subterrânea de diferentes condutividades elétricas coletadas em setembro de 2015. A localização dos poços de amostragem está exposta na Figura 4.1. Somente a amostra “CN 09/2015" está localizada na Faixa Móvel Riacho do Pontal, as demais se localizam no Cráton São Francisco. As análises foram realizadas no laboratório HIDROISOTOP localizado na Alemanha pelo método de Accelerator Mass-spectrometry (AMS); medido em \% recente com desvio padrão duplo, 100\%-modern $=0,226 \mathrm{~Bq} / \mathrm{g}$ Carbon.

Os resultados de Trítio foram muito pequenos (inferiores ao limite de quantificação do aparelho) e não houve variação entre as amostras. Dessa forma, as idades foram estimadas utilizando o método do Carbono 14. Os dados brutos de Carbono 14 obtidos nas análises foram substituídos na equação fornecida por Allègre (2008).

$$
T=-8033 \cdot \ln \frac{A_{t}^{14}}{A_{0}^{14}}
$$

Onde a razão $\mathrm{A}^{14}{ }_{\mathrm{t}} / \mathrm{A}^{14}{ }_{0}$ foi determinada pela análise das amostras pelo laboratório HIDROISOTOP. A Tabela 4.3 mostra os resultados dos cálculos das estimativas de idades obtidos com a equação 4.02. 
Tabela 4.3 - Dados de datação por trítio e carbono 14 para as amostras de água subterrânea do município de Petrolina.

\begin{tabular}{|c|c|c|c|c|c|}
\hline Amostra & Trítio & $\begin{array}{c}\text { Carbono 13 } \\
\left(\boldsymbol{\delta}^{13} \mathrm{C}-\mathrm{DIC}\right) \\
\% 0\end{array}$ & $\begin{array}{c}\text { Carbono 14 } \\
\left(\begin{array}{c}\left.{ }^{4} \mathrm{C}-\mathrm{TIC}\right) \\
\% \text {-modern }\end{array}\right.\end{array}$ & $\begin{array}{c}\text { Idades } \\
\text { aproximadas } \\
(\text { anos })\end{array}$ & $\begin{array}{c}\text { Condutividade } \\
\text { Elétrica } \\
(\boldsymbol{\mu S} / \mathrm{cm})\end{array}$ \\
\hline RKF $(09 / 2015)$ & $<0,6$ & $-11,1$ & $96,55 \pm 0,56$ & $282 \pm 45$ & 12.630 \\
\hline $113(09 / 2015)$ & $<0,6$ & $-11,7$ & $93,63 \pm 0,54$ & $528 \pm 43$ & 3.490 \\
\hline $\mathrm{CN}(09 / 2015)$ & $0,6 \pm 1,0$ & $-12,3$ & $74,99 \pm 0,44$ & $2.312 \pm 35$ & 1.876 \\
\hline JA $(09 / 2015)$ & $<0,6$ & $-13,5$ & $50,13 \pm 0,34$ & $5.547 \pm 27$ & 2.720 \\
\hline
\end{tabular}

\subsection{Sistemas Piloto de Recarga Artificial}

A locação dos sistemas piloto de recarga artificial foi realizada em 2013, as obras de construção foram realizadas em outubro de 2014, e as injeções diretas para monitoramento foram realizadas em dezembro de 2014 e março de 2015. O sistema está explicado de maneira detalhada na seção 1.5 do Capítulo 1. A localização dos sistemas pilotos está exposta na Figura 1.6. Todos se localizam em rochas do Cráton São Francisco.

Devido a problemas financeiros relacionados ao Projeto RECARFRAT não foi possível à construção dos sistemas em tempo hábil para que os testes fossem realizados de maneira natural com a água da chuva. Dessa forma, os sistemas foram testados em campos realizados em dezembro de 2014 e março de 2015 com o uso de caminhões pipa, que foram contratados para pegar água do Rio São Francisco e da rede de canais de irrigação e jogar nas trincheiras de recarga acelerando o processo. Durante os testes foram monitorados o volume de água injetado e o tempo de infiltração, além de serem coletadas amostras para análises de condutividade elétrica, Eh, $\mathrm{pH}$ e isótopos estáveis ( $\mathrm{D}$ e O).

As análises de isótopos estáveis foram realizadas no Laboratório de Geocronologia da UnB no aparelho da marca PICARRO modelo L2120- $i \delta \mathrm{D}$ e $\delta^{18} \mathrm{O}$ Analyzer; e as de condutividade elétrica, Eh e $\mathrm{pH}$ foram realizadas em campo com o aparelho multiparâmetro da marca HACH modelo HQ40D.

\section{Sistema Piloto da Escola Municipal}

O Sistema Piloto da Escola Municipal não obteve êxito no processo de recarga artificial. Isso ocorreu devido a problemas detectados somente no momento da escavação da trincheira, quando a perfuração do poço e instalação das calhas já havia sido concluída. A trincheira deveria ter sido escavada até o contato solo-rocha deixando a fratura conectada com a trincheira. Porém, no momento da escavação foi detectada presença de uma camada de micaxisto próximo à superfície que não conseguiu ser ultrapassada pela retro escavadeira. Esse nível de xisto diminuiu consideravelmente a capacidade de infiltração da água na trincheira e serviu como uma barreira hidráulica para a passagem de água que não conseguiu atingir a fratura monitorada pelo poço.

Por esse motivo, na primeira tentativa de injeção realizada em 07/12/2014 a água da trincheira não infiltrou em taxas mínimas para se determinar a efetividade do sistema piloto. Assim, não foram realizados testes adicionais neste sítio (Figura 4.11).

$\mathrm{O}$ acontecimento ressalta que a existência de camadas impermeáveis próximos à superfície é um fator limitante para aplicação de técnicas de recarga artificial em ambientes rasos conforme abordado anteriormente por vários estudos. 


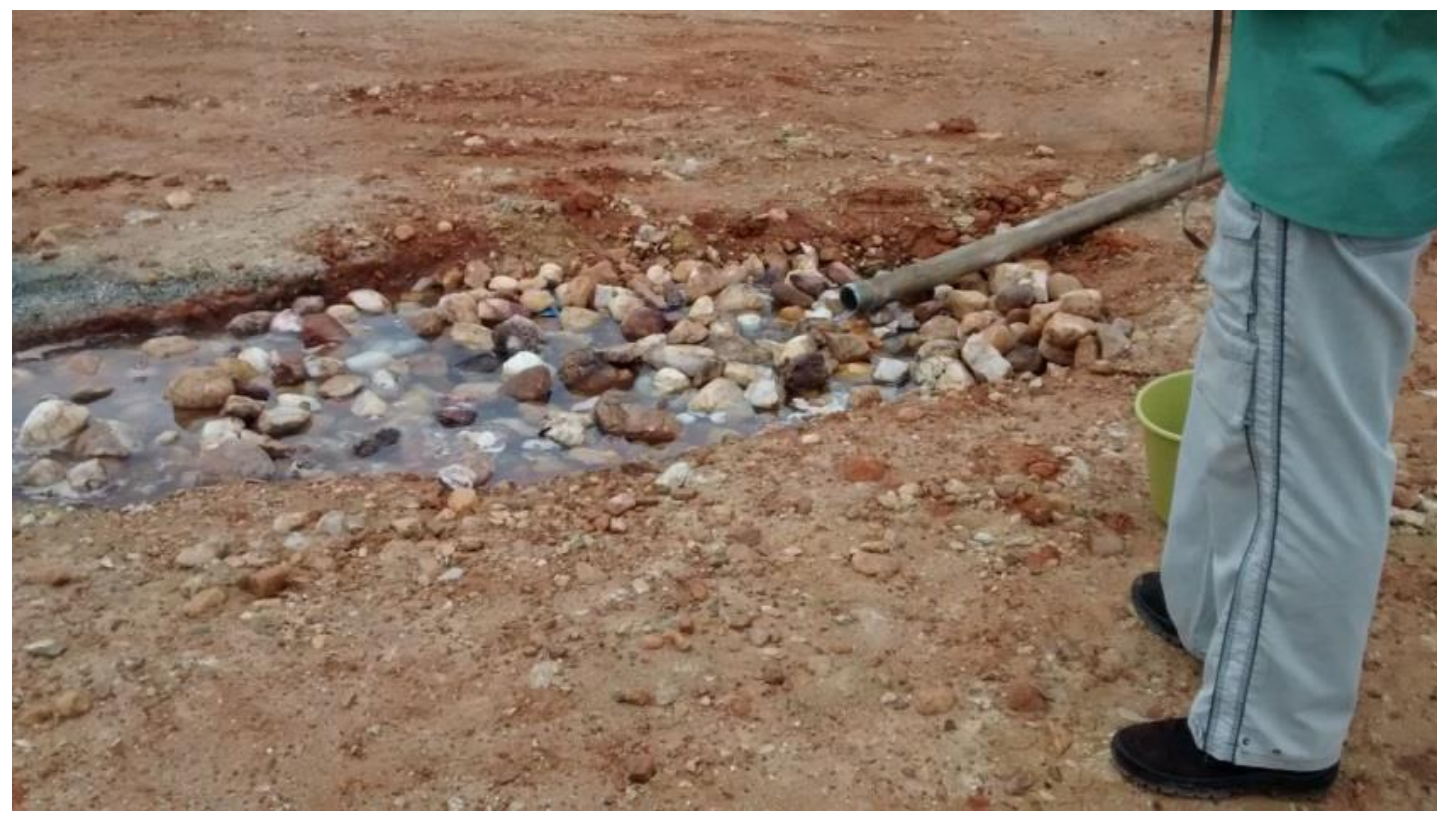

Figura 4.11 - Água sendo injetada pelo caminhão pipa diretamente na trincheira no Sistema Piloto da Escola Municipal. A camada de xisto presente próximo à superfície se comportou como uma barreira hidráulica não permitindo que a água infiltrasse e chegasse à fratura monitorada pelo poço.

\section{Sistema Piloto da RKF mudas}

Foi realizado teste no Sistema Piloto da RKF mudas em março de 2015. Em dezembro de 2014 não foi possível a realização do teste, pois a bomba do poço estava com defeito.

O teste foi realizado em 25/03/2015 onde foram injetados 20.000 litros de água do Rio São Francisco com auxílio de caminhões pipa.

Dois fatores relacionados à trincheira de recarga do Sistema Piloto da RKF Mudas influenciaram no seu monitoramento. O primeiro é que ela está mais distante do poço de

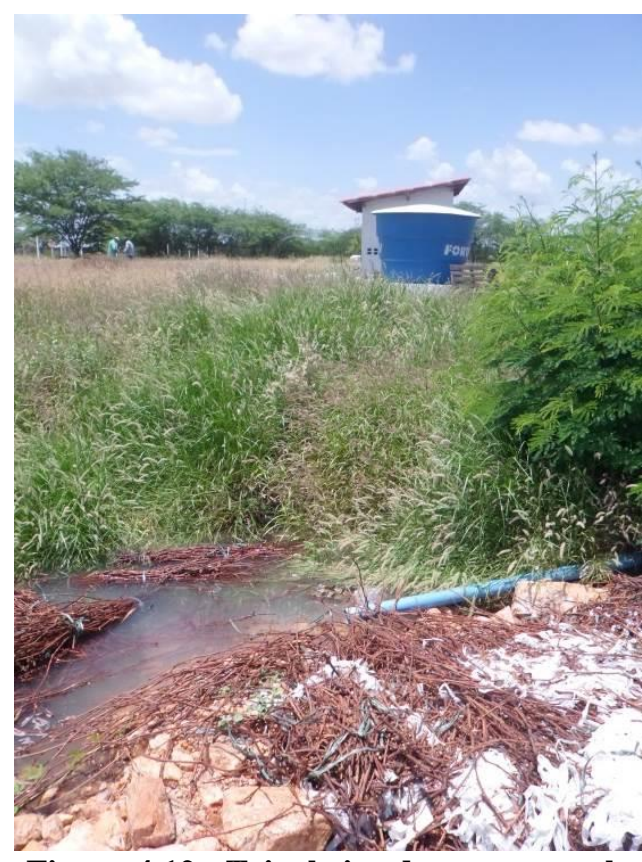

Figura 4.12 - Trincheira de recarga mal preenchida e localizada mais distante do poço de monitoramento no Sistema Piloto da RKF mudas. monitoramento comparativamente aos outros dois sistemas. E o segundo, é que houve um problema no preenchimento da trincheira, além do cascalho foi colocada areia, o que torna mais lenta a infiltração e, consequentemente, a chegada da água de recarga na fratura interceptada pelo poço (Figura 4.12). Por esses motivos era previsto que a chegada da resposta da recarga artificial no poço de monitoramento seria mais demorada.

Para adequar o tempo de chegada da recarga ao tempo disponível para realização da saída de campo, o poço de monitoramento foi colocado em bombeamento com vazão constante no início do teste. O objetivo era aumentar o espaço disponível no aquífero para a chegada da água de recarga acelerando o processo. A bomba ficou ligada das $8 \mathrm{~h} 20$ as $16 \mathrm{~h} 20$ do dia 25/03 com vazão constante de $1.700 \mathrm{~L} / \mathrm{h}$ totalizando um volume de 13.600L de água retirados do aquífero.

Foram realizadas 2 injeções de água do Rio São Francisco por caminhões pipa na trincheira (Tabela 4.4). 
As 2 infiltrações foram rápidas devido ao grande volume de água que a trincheira comporta.

Tabela 4.4 - Características das águas de recarga utilizadas no teste do Sistema Piloto da RKF mudas.

\begin{tabular}{|c|c|c|c|c|c|c|c|c|c|c|c|}
\hline & Águas & $\begin{array}{l}\text { Amostra de } \\
\text { isótopo }\end{array}$ & $\begin{array}{l}\text { Condutividade } \\
\text { Elétrica }\end{array}$ & pH & Eh & $\begin{array}{c}\mathbf{T} \\
\left({ }^{\circ} \mathbf{C}\right)\end{array}$ & $\begin{array}{c}\delta D_{\text {SMow }} \\
(\% 0)\end{array}$ & $\begin{array}{c}\delta 0_{\text {SMOW }}^{18} \\
(\%)\end{array}$ & Injeção & $\begin{array}{l}\text { Volume } \\
\text { de água } \\
\text { injetado }\end{array}$ & $\begin{array}{c}\text { Tempo } \\
\text { de } \\
\text { injeção }\end{array}$ \\
\hline \multicolumn{2}{|c|}{$\begin{array}{l}\text { Água inicial do } \\
\text { aquífero }\end{array}$} & RKF-III-01 & $12,64 \mathrm{mS} / \mathrm{cm}$ & 7,35 & $-63,6$ & 29,1 & $-29,09$ & $-4,60$ & & & \\
\hline \multirow{2}{*}{ 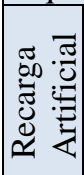 } & $\begin{array}{l}\text { Rio São } \\
\text { Francisco } \\
\end{array}$ & RSF-III-01 & $65,9 \mu \mathrm{S} / \mathrm{cm}$ & 9,10 & $-164,3$ & 27,2 & $-16,28$ & $-2,8$ & $1^{\mathrm{o}}$ & $11.000 \mathrm{~L}$ & $\begin{array}{c}18 \\
\min .\end{array}$ \\
\hline & $\begin{array}{l}\text { Rio São } \\
\text { Francisco }\end{array}$ & RSF-III-01 & $68,6 \mu \mathrm{S} / \mathrm{cm}$ & 9,01 & $-159,2$ & 27,6 & $-16,28$ & $-2,8$ & $2^{\circ}$ & $9.000 \mathrm{~L}$ & $\begin{array}{c}25 \\
\min .\end{array}$ \\
\hline
\end{tabular}

O sistema foi monitorado da manhã do dia 25/03 até o final da tarde do dia 27/03, totalizando 56horas e 15 minutos de monitoramento. A condutividade elétrica, o Eh e o pH foram medidos inicialmente de hora em hora no primeiro dia. Após 24 horas do início do teste as medições passaram a ser realizadas de 30 em 30 minutos nos 2 dias seguintes. Já as amostras de isótopos foram coletadas de 2 em 2 horas no primeiro dia e nos dias seguintes de hora em hora. Durante a noite as medições eram interrompidas e retomadas no começo da manhã do dia seguinte (Figura 4.13).

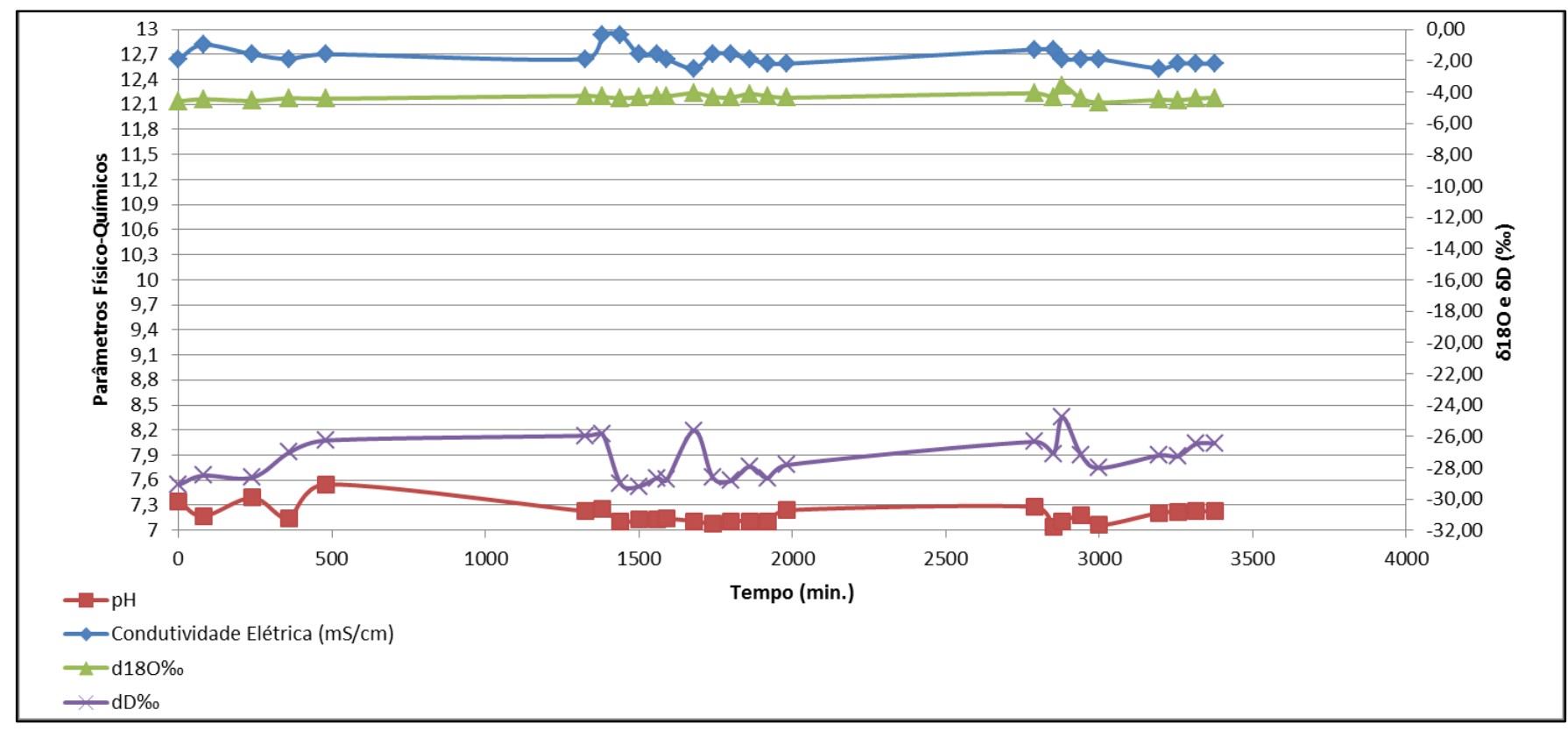

Figura 4.13 - Monitoramento do Sistema Piloto da RKF mudas.

\section{Sistema Piloto da Fazenda do Jair}

Os testes no Sistema Piloto da Fazenda do Jair foram realizados em dezembro de 2014 e março de 2015 e foram os que obtiveram os melhores resultados.

Os primeiros testes no Sítio Juazeiro foram realizados em dezembro de 2014 e serviram como base para o monitoramento do Sistema Piloto da RKF mudas. Foram injetados 2 pulsos de água sendo que no primeiro foram lançados 7.000 L de água do Rio São Francisco e 16.000 L de água da rede de canais de irrigação no dia 07/12/2014. Já no segundo pulso foram injetados 8.000 L do Rio São Francisco e 8.000 L da rede de canais de irrigação no dia 09/12/2014. O monitoramento ocorreu entre os dias 07 e 11/12/2014 com a coleta de amostras para análise de condutividade elétrica e $\mathrm{pH}$, em campo, e para análise de isótopos estáveis em laboratório. A Tabela 4.5 apresenta as características das águas envolvidas no processo. 
Na Tabela 4.5 é possível observar a diferença de tempo de infiltração entre as injeções. As primeiras injeções são rápidas e as seguintes mais demoradas. Uma possível explicação para isso é a perda lateral por interfluxo no solo nas primeiras injeções. Conforme as injeções seguem o fluxo lateral diminui e se concentra no fluxo vertical.

Tabela 4.5 - Características das águas de recarga utilizadas no teste do Sistema Piloto da Fazenda do Jair.

\begin{tabular}{|c|c|c|c|c|c|c|c|c|c|c|c|}
\hline \multicolumn{2}{|c|}{ Águas } & $\begin{array}{l}\text { Amostra de } \\
\text { isótopo }\end{array}$ & $\begin{array}{l}\text { Condutividade } \\
\text { Elétrica }\end{array}$ & pH & $\begin{array}{c}\mathbf{T} \\
\left({ }^{\circ} \mathbf{C}\right)\end{array}$ & $\begin{array}{c}\delta D_{\text {SMow }} \\
(\%)\end{array}$ & $\begin{array}{c}\delta 0^{18}{ }_{\text {SMOW }} \\
(\% \text { ) }\end{array}$ & $\frac{8}{2}$ & 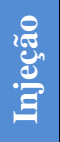 & $\begin{array}{l}\text { Volume } \\
\text { de água } \\
\text { injetado }\end{array}$ & $\begin{array}{c}\text { Tempo } \\
\text { de } \\
\text { injeção }\end{array}$ \\
\hline \multicolumn{2}{|c|}{$\begin{array}{l}\text { Água inicial do } \\
\text { aquífero }\end{array}$} & JA-01 & $4,44 \mathrm{mS} / \mathrm{cm}$ & 7,76 & 30,7 & $-25,01$ & $-4,26$ & & & & \\
\hline \multirow{5}{*}{ 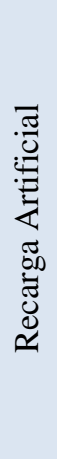 } & $\begin{array}{l}\text { Rio São } \\
\text { Francisco }\end{array}$ & RSF-01 & $156,7 \mu \mathrm{S} / \mathrm{cm}$ & 9,51 & 28,3 & $-11,61$ & $-1,51$ & 1 & 1 & $7.000 \mathrm{~L}$ & $30 \mathrm{~min}$ \\
\hline & $\begin{array}{l}\text { Canal de } \\
\text { Irrigação }\end{array}$ & CAN-01 & $221 \mu \mathrm{S} / \mathrm{cm}$ & 9,72 & 28,7 & 7,06 & 2,04 & 1 & 2 & $8.000 \mathrm{~L}$ & $1 \mathrm{~h} 30$ \\
\hline & $\begin{array}{l}\text { Canal de } \\
\text { Irrigação }\end{array}$ & CAN-01 & $221 \mu \mathrm{S} / \mathrm{cm}$ & 9,72 & 28,7 & 7,06 & 2,04 & 1 & 3 & $8.000 \mathrm{~L}$ & $2 \mathrm{~h} 10$ \\
\hline & $\begin{array}{l}\text { Rio São } \\
\text { Francisco }\end{array}$ & RSF-01 & $156,7 \mu \mathrm{S} / \mathrm{cm}$ & 9,51 & 28,3 & $-11,61$ & $-1,51$ & 2 & 1 & $8.000 \mathrm{~L}$ & $45 \mathrm{~min}$ \\
\hline & $\begin{array}{l}\text { Canal de } \\
\text { Irrigação }\end{array}$ & CAN-01 & $221 \mu \mathrm{S} / \mathrm{cm}$ & 9,72 & 28,7 & 7,06 & 2,04 & 2 & 2 & $8.000 \mathrm{~L}$ & $3 \mathrm{~h} 40$ \\
\hline
\end{tabular}

A condutividade elétrica e o $\mathrm{pH}$ foram medidos a cada 1 hora e posteriormente a cada 30 minutos no primeiro dia (07/12). No segundo dia (08/12) foram coletadas 3 amostras, uma de manhã outra a tarde e outra a noite. No terceiro dia (09/12), quando foi realizado o segundo pulso de injeção, amostras foram coletadas a cada 30 minutos. No dia 10 houve uma mudança nas características da água subterrânea indicando a possível chegada da água de recarga, por isso amostras foram coletadas em intervalos mais curtos de tempo. No dia 11/12 amostras foram coletadas 3 vezes ao dia de manhã, de tarde e de noite. Já as amostras para analise de isótopos estáveis foram coletadas a cada 2 horas no primeiro dia; no segundo dia foram coletadas 3 amostras (manhã, tarde e noite); no terceiro dia voltaram a ser coletadas de 2 em 2 horas. No dia 10 houve uma mudança nas características da água subterrânea indicando a possível chegada da água de recarga, por isso amostras foram coletadas em intervalos mais curtos de tempo. No dia 11/12 amostras foram coletadas 3 vezes ao dia de manhã, de tarde e de noite. Durante a noite as medições eram interrompidas e retomadas no começo da manhã do dia seguinte.

A Figura 4.14 apresenta o monitoramento do sistema de recarga artificial. As características das águas de recarga são nitidamente distintas das águas presentes no aquífero. Através da análise do gráfico pode-se constatar que houve uma mudança significativa nos parâmetros da água do aquífero em 2 momentos distintos marcados pelos 2 picos presentes no gráfico (em 4.000 e 5.500 minutos). A condutividade elétrica diminuiu; e o $\mathrm{pH}$, o $\delta^{18} \mathrm{O}$ e o $\delta \mathrm{D}$ aumentam. Estima-se que o primeiro pulso esteja relacionado à primeira injeção de água e o segundo a segunda.

$\mathrm{Na}$ propriedade do Senhor Jair, existem seis poços tubulares que são relativamente próximos, porém possuem características hidráulicas (vazão e nível estático) bastante distintas. A Figura 4.15 mostra a seção transversal da fazenda do Sr. Jair elaborada com os dados coletados nos 6 poços. Na seção não estão representadas as profundidades corretas dos poços, somente os níveis estáticos e as distâncias entre eles que está em escala. 


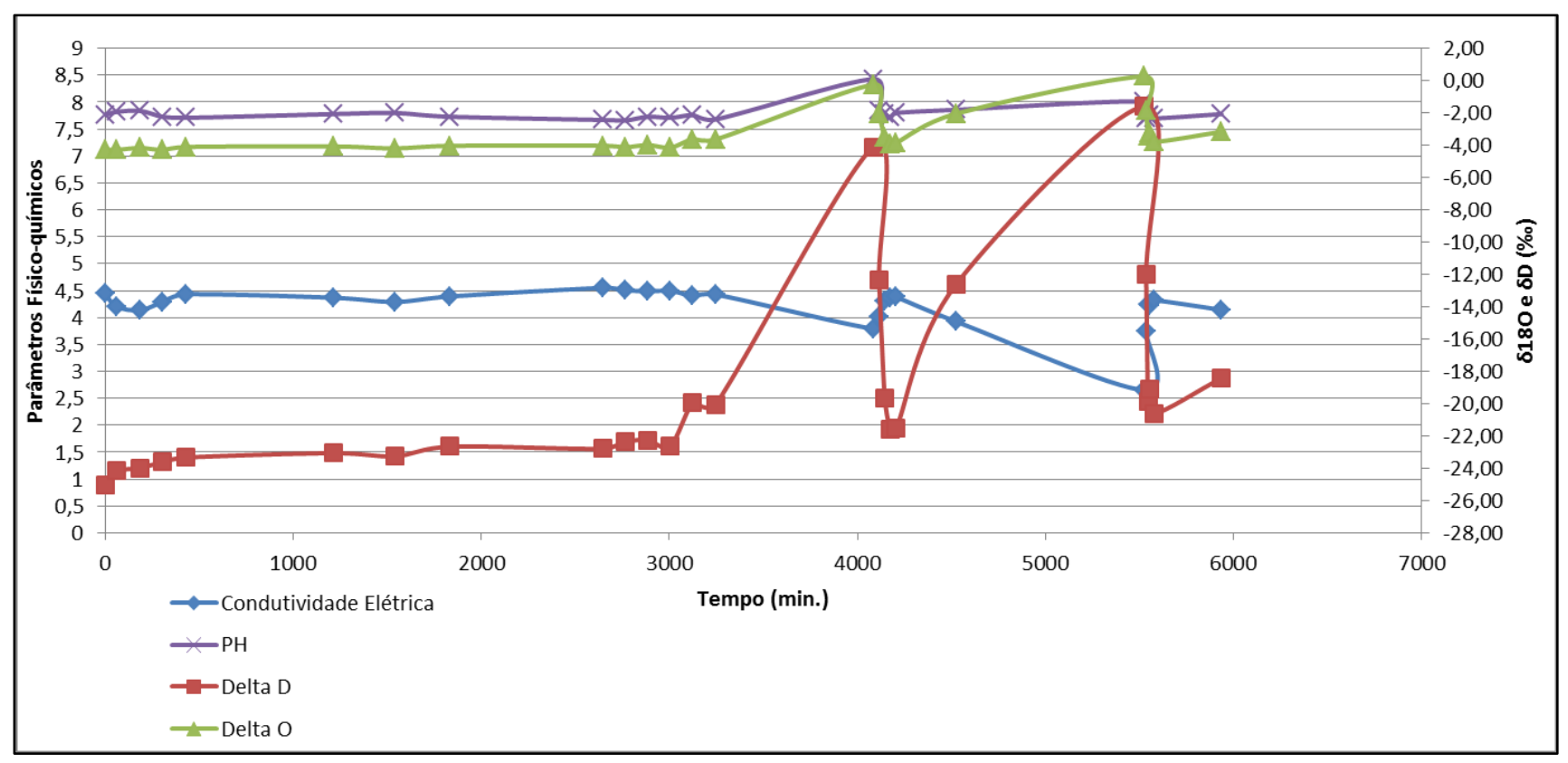

Figura 4.14 - Monitoramento do Sistema Piloto da Fazenda do Jair.

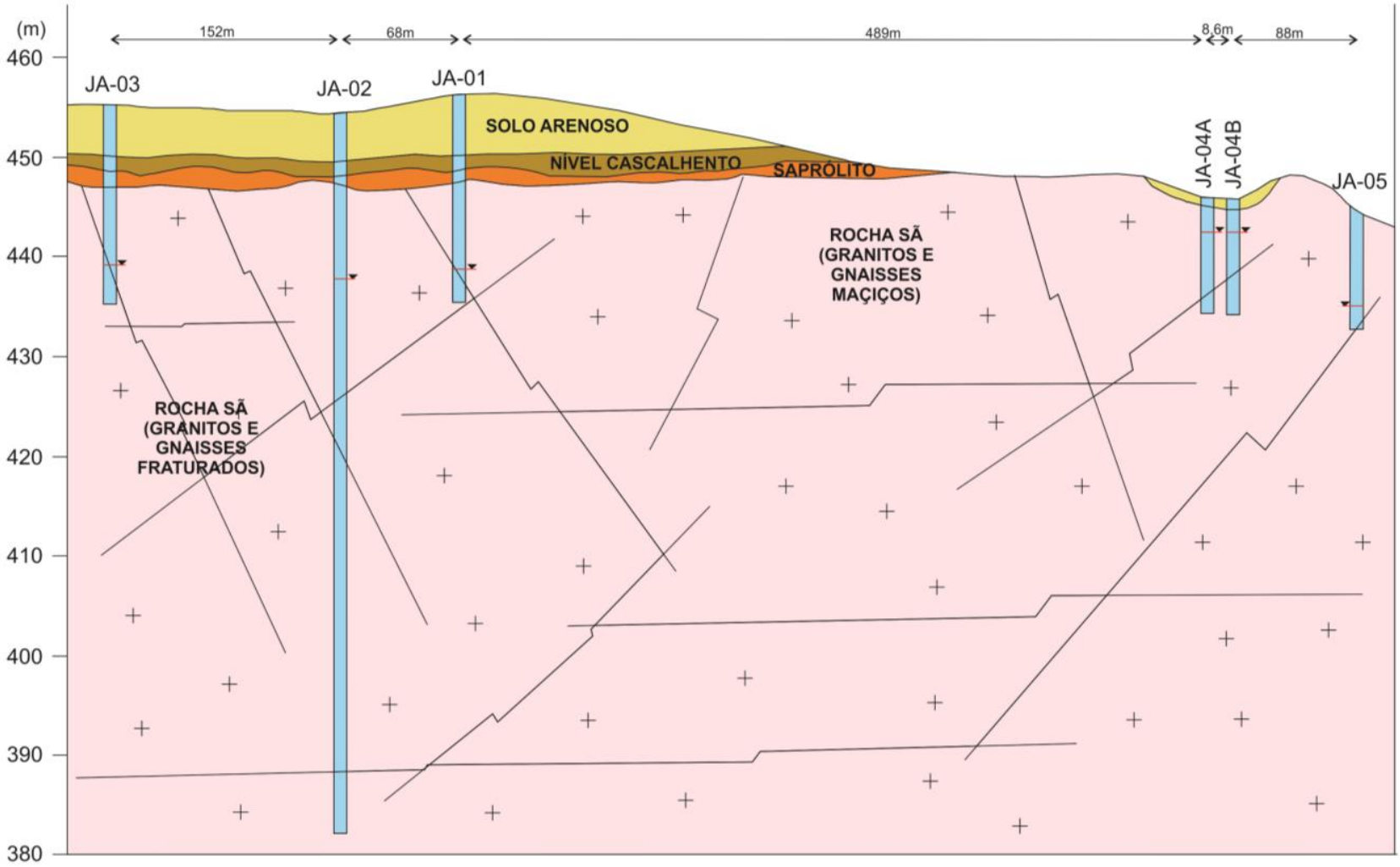

Figura 4.15 - Seção esquemática simplificada dos poços presentes na fazenda do Senhor Jair.

Poços localizados a dezenas de metros uns dos outros possuem níveis estáticos e vazões distintos indicando que estão captando água de sistemas de fraturas distintas. Isso ressalta a baixa conectividade das fraturas na área.

A tentativa de teste realizada em março de 2015 teve que ser interrompida devido a problemas de oscilação de energia que não permitiram o funcionamento da bomba. Sendo assim, não foi possível a coleta das amostras e o teste teve que ser suspenso. 


\section{CAPÍTULO 5}

\section{DISCUSSÕES}

Os poços utilizados para estudo no município de Petrolina apresentam perfis construtivos similares o que permite que resultados sejam obtidos mesmo sem informações construtivas detalhadas de todos os poços. Como os solos são pouco espessos, os poços tubulares, em geral, são perfurados com diâmetro de 8" até o contato solo-rocha, e diâmetro de 6" até que seja encontrada água em vazões suficientes. O tubo de revestimento é colocado somente na porção do solo onde é feita a cimentação. Não são utilizados filtros ou pré-filtros ou lamas de perfuração. Assim, os perfis construtivos detalhados dos poços não influenciam de maneira significativa na interpretação dos resultados. Algumas exceções são os poços que são perfurados nos aluviões, onde a porção de sedimentos superior é mais espessa, podendo ter seções filtrantes.

A análise hidroquímica das 232 amostras selecionadas pela avaliação do balanço iônico e divididas em 8 grupos de acordo com suas condutividades elétricas está resumida na Figura 4.5. Os TDS detectados nas águas variam de 104,8 a 19.703,5 mg/L. Sendo assim, segundo a classificação expressa em Freeze \& Cherry (1979), elas são classificadas como águas frescas (até $1.000 \mathrm{mg} / \mathrm{L})$, salobras (1.000 mg/L a $10.000 \mathrm{mg} / \mathrm{L})$ e águas salinas $(10.000-100.000 \mathrm{mg} / \mathrm{L})$.

$\mathrm{Na}$ Figura 4.5, é possível observar que existe uma relação entre a condutividade elétrica e a composição hidroquímica das amostras principalmente com relação aos ânions. As amostras menos condutivas possuem maior quantitativo de bicarbonato e conforme as condutividades aumentam, aumenta também o quantitativo de cloreto. Essa mudança é gradual e acompanha o aumento da condutividade, conforme mostrado nos Diagramas de Piper.

A Figura 4.7 mostra as relações dos principais íons com a condutividade elétrica para as 232 amostras. A determinação dos íons que possuem correlação com a condutividade foi feita com base na análise do $\mathrm{R}^{2}$, quando $\mathrm{R}^{2}>0,7$ a correlação foi considerada existente. Isso ocorreu para os íons: flúor, fosfato, sódio, cálcio e magnésio. O cloro e o bromo apresentaram forte correlação com $R^{2}$ de 0,9686 e 0,9546 , respectivamente.

Altas concentrações de cloro podem estar ligadas a contaminação antrópica por efluentes domésticos (WILLIAM \& HAUGH, 2001; OLIVA \& KIANG, 2002) ou a evolução hidroquímica durante o fluxo das águas subterrâneas (SILVA \& REBOUÇAS, 1983). O segundo caso parece ser o mais indicado para explicar o comportamento das águas subterrâneas de Petrolina, pois os poços analisados estão localizados na área rural do município onde a ocupação humana é muito restrita. Nesse caso, o cloreto pode ter origem meteórica, na forma de aerossóis que são carreados para o interior dos continentes; ou ter origem na dissolução de minerais intemperizados principalmente a biotita e a muscovita que ocorrem de forma disseminada na região.

No primeiro caso, os aerossóis incluem partículas de solo levadas pelo vento, especialmente em regiões semiáridas de origem proveniente de poeira de rocha; de sal de borbulhamento de água do mar na superfície dos oceanos; de erupções vulcânicas; ou de origem antropogênica tal como fumaça e fuligem de combustão. Já no segundo caso, o cloreto ocorre como substituinte da hidroxila na estrutura cristalina. O fluoreto deve ter o mesmo 
comportamento do cloreto, sendo também um constituinte de substituição da hidroxila e pode ocorrer na forma de fluorita que ocorre na forma de minerais acessórios e granitos.

As águas subterrâneas aumentam seu conteúdo de sólidos dissolvidos conforme se movem no fluxo do aquífero na zona saturada. Freeze \& Cherry (1979), através da análise de diversos estudos observaram que as águas subterrâneas tendem a evoluir quimicamente no decorrer do fluxo de forma a se assemelharem a composição da água do mar. Essa evolução sugere que modificações regionais ocorram determinadas pelo tempo de residência das águas ao longo do fluxo. As principais modificações ocorrem no que tange aos ânions.

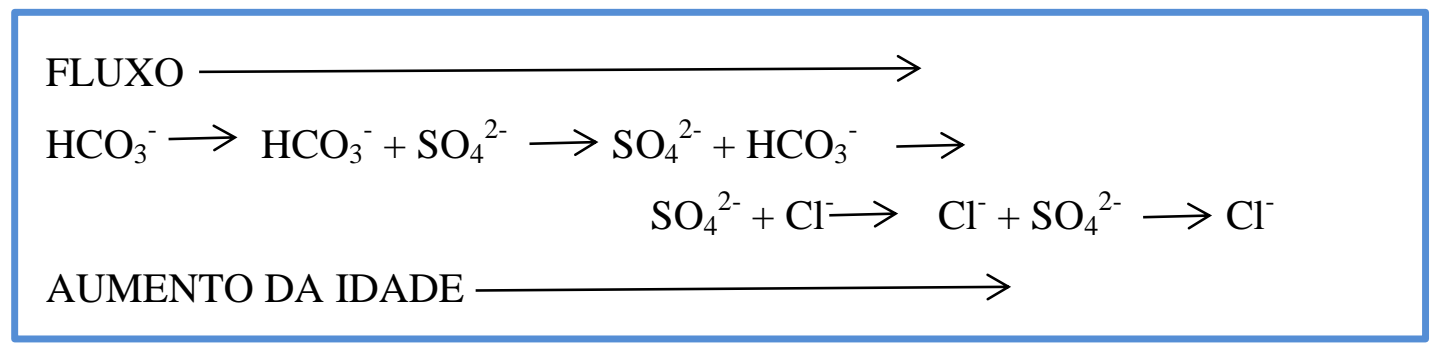

Freeze \& Cherry (1979) apresentam as seguintes denominações para essa evolução: sequência evolutiva de íons maiores, Sequência de Ignatovich e Souline e Sequência de Chebotarev.

Silva \& Rebouças (1983) chamam essa sequência de "esquema clássico de evolução química de águas subterrâneas". Três zonas são sugeridas nesta evolução para aquíferos porosos em grandes bacias sedimentares, e em geral as zonas são correlacionáveis com a profundidade do aquífero. São elas:

- Zona superior - é caracterizada por rápida circulação através de rochas relativamente bem lixiviadas com predomínio do ânion bicarbonato e pequena quantidade de TDS;

- Zona intermediária - apresenta circulação mais lenta, concentração mais elevada de TDS e predominância do ânion sulfato;

- Zona inferior - é onde o fluxo é muito lento determinando a presença de minerais altamente solúveis, predominância do ânion cloreto e elevado TDS.

A ocorrência dessas zonas depende do tempo de permanência da água no aquífero e da presença de minerais que sirvam de fonte para os ânions (SILVA \& REBOUÇAS, 1983). Não é possível especificar o tempo ou a distância percorrida em cada zona somente que ambos tendem a aumentar da zona superior para a inferior (FREEZE \& CHERRY, 1979).

A explicação geoquímica para a sequência dada por Freeze \& Cherry (1979) se baseia na disponibilidade e na solubilidade dos minerais. $\mathrm{O}$ íon bicarbonato na água subterrânea é derivado do $\mathrm{CO}_{2}$ dos solos e da dissolução de carbonatos, e é abundante próximo à zona de recarga. $\mathrm{O}$ sulfato é derivado principalmente da dissolução de gipsita e anidrita, que são mais solúveis que os carbonatos e por isso quando presentes nos aquíferos se dissolvem e a água residual fica enriquecida em sulfato. Isso ocorre a certa distância da área de recarga, pois esses minerais são encontrados em concentrações traço e dificilmente estão presentes em zonas rasas dos aquíferos. Quando as águas atingem grandes profundidades e encontram minerais portadores de $\mathrm{Cl}$ que são extremamente solúveis elas se tornam enriquecidas em cloreto.

Os autores relatam que quando existem poucos minerais portadores de sulfatos e cloretos, a difusão do $\mathrm{Cl}$ que é um processo extremamente lento pode tornar a evolução química um processo gradual ao invés de se dá por estágios distintos como é esperado levando em consideração somente a solubilidade dos minerais (FREEZE \& CHERRY, 1979). 
Silva \& Rebouças (1983) relatam um aumento da temperatura e da salinidade das águas do Aquífero Botucatu desde a zona de afloramento (área de recarga) até a região fortemente confinada do aquífero. Nesse sentido, as águas evoluem de bicarbonatadas magnesianas e calco magnesianas para bicarbonatadas cálcicas, bicarbonatadas sódicas e cloro-sulfatadas sódicas quando chegam a atingir idades da ordem de 30.000 anos. $\mathrm{O}$ aumento gradativo e constante do cloreto da área de recarga em direção ao fluxo do aquífero é explicado pelos autores pela alta solubilidade dos minerais portadores de cloro e pelo longo tempo de permanência desse íon nas águas do aquífero.

As águas subterrâneas do município de Petrolina se comportam como previsto pela Sequência de Chebotarev descrita por Silva \& Rebouças (1983) e Freeze \& Cherry (1979), sob a exceção de não apresentarem concentrações de sulfato esperadas na zona intermediária. Estudos mais detalhados da geologia da área são necessários para explicar a ausência de tal íon. Como descrito por Freeze \& Cherry (1979), a evolução gradual observada pode ser em decorrência da difusão do cloro. Outra possível explicação é o enriquecimento residual do cloro. O cloreto em solução é estável e inerte e dificilmente forma precipitados ou é adsorvido pelos argilominerais, assim se torna relativamente enriquecido no momento em que os outros íons vão sendo adsorvidos e precipitados e ele se torna residual (Figura 5.1). A origem desse elemento nas águas subterrâneas de Petrolina pode ter contribuição tanto meteórica, quanto por dissolução de minerais sendo que estudos mais detalhados devem ser feitos para maiores esclarecimentos.

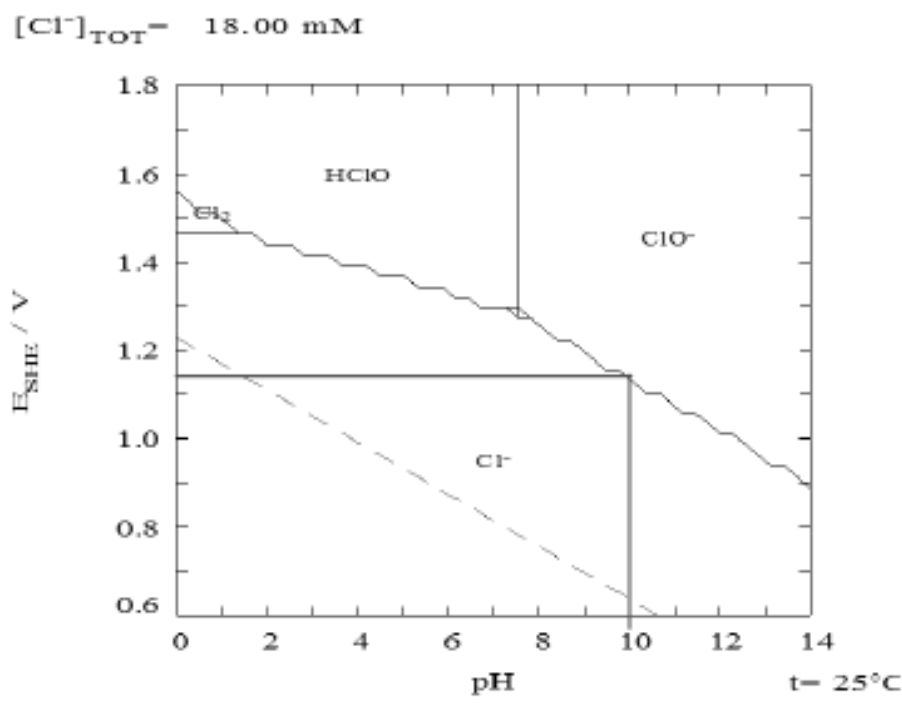

Figura 5.1 - Diagrama Eh x pH do elemento cloro considerando $\left[\mathrm{Cl}^{-}\right]_{\mathrm{TOT}}=18.00 \mathrm{mM}$ a $\mathrm{T}=25^{\circ} \mathrm{C}$. Mostrando que sob as condições das águas subterrâneas, predominantemente redutoras, a forma estável do cloro é em solução $\mathrm{Cl}^{-}$.

Andrade \& Leal (2010), em seus estudos no semiárido da Bahia, associam a alta correlação do STD (Sólidos Totais Dissolvidos) com o cloro e a baixa correlação do STD com o bicarbonato a indicativos de que a origem das elevadas salinidades das águas subterrâneas não está predominantemente associada ao processo de interação água-rocha. Os autores explicam que o bicarbonato é fruto principalmente da interação água-rocha, já o cloreto não é hidromórfico, sendo esperada baixa liberação desse íon a partir da decomposição das rochas da área estudada (ANDRADE \& LEAL, 2010).

O bromo geralmente é encontrado em águas subterrâneas associado ao cloro. Diferentemente do cloro (que nas amostras de Petrolina varia entre 4,57 e 10.818,21 mg/L), que 
é considerado elemento maior, o bromo é considerado elemento traço e ocorre em pequenas concentrações na água subterrânea (em Petrolina varia entre 0,02 a 35,89 mg/L).

A presente análise permitiu caracterizar a evolução química das águas subterrâneas de diferentes salinidades nos aquíferos fraturados do município de Petrolina. Supõe-se que o principal fenômeno modificador da composição química das águas durante essa evolução seja o enriquecimento do cloro residual ou decorrente da difusão. Entretanto, novos estudos devem ser realizados para caracterização dos fenômenos modificadores e determinação da origem desse elemento se meteórico ou por dissolução de minerais.

O nitrato é uma substância que ocorre em elevados teores em inúmeras amostras de águas subterrâneas. Como não existe nenhum mineral com nitrato em sua estrutura na região, esta substância apenas pode ser considerada como contaminação por atividades antrópicas. A pecuária e agricultura são atividades que explicam a introdução de nitrato nas áreas subterrâneas da região.

As análises de isótopos estáveis realizadas para caracterização isotópica regional estão expressas na Figura 4.8. Para uma análise mais detalhada foram escolhidas somente 2 curvas de água meteórica locais que mais se assemelham as características climáticas do município de Petrolina, são elas: a da estação de Floresta da IAEA e a curva descrita por Silveira \& Silva Junior (2002) para a região nordeste. Estas foram plotadas juntamente com a GMWL e com as amostras de água subterrânea do município no gráfico $\delta \mathrm{D} \times \delta^{18} \mathrm{O}$ (Figura 5.2).

Andrade \& Leal (2010) citam análises isotópicas realizadas em amostras de água subterrânea de aquíferos fraturados no vale do Curaçá (Bahia) e na região de Uauá (Bahia) que apresentaram, para as amostras mais salinas, um enriquecimento em isótopos pesados resultado da forte evaporação característica do semiárido. Entretanto, a maioria das amostras coletadas no município de Petrolina surpreendentemente apresenta enriquecimento em isótopos leves e está localizada acima das curvas da água meteórica global e locais. Elas encontram-se alinhadas formando uma linha, que nessa dissertação é denominada de "linha da água subterrânea de Petrolina". A equação da reta está explicitada no gráfico.

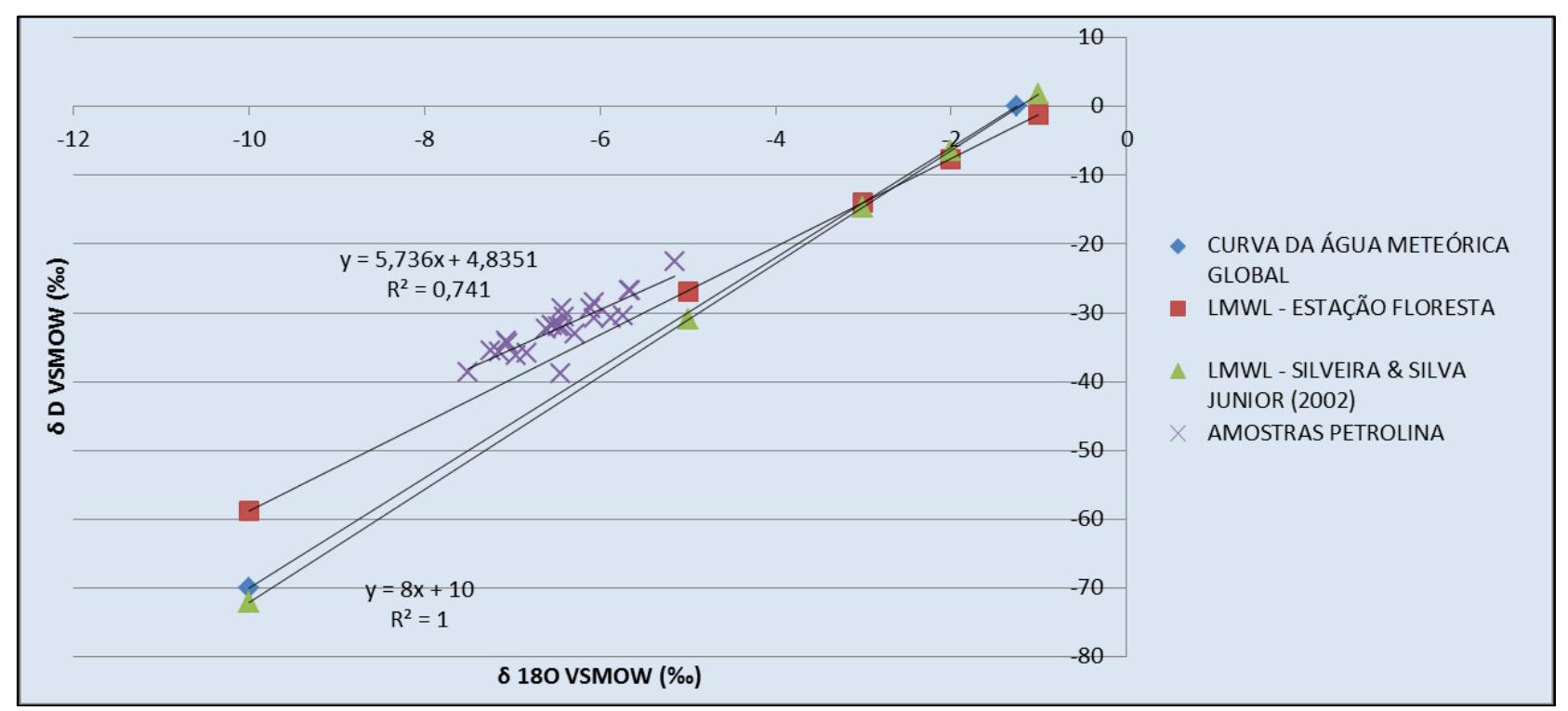

Figura 5.2 - Amostras de água subterrânea de Petrolina plotadas juntamente com GMWL e com a LMWL. As amostras estão localizadas acima das linhas (mostrando enriquecimento em isótopos leves) e encontram-se alinhadas formando uma linha denominada "linha da água subterrânea de Petrolina". 
Frape et al. (1984) descrevem uma situação parecida em águas subterrâneas de 4 minas localizadas em aquíferos fraturados do Canadá. Amostras de poços de diferentes profundidades foram analisadas. Águas frescas foram encontradas a menos de 650 metros de profundidade com TDS < $10.000 \mathrm{mg} / \mathrm{L}$; e águas salinas e salmouras foram encontradas a mais de $650 \mathrm{~m}$ de profundidade com TDS $>325.000 \mathrm{mg} / \mathrm{L}$. Os autores relatam que o grupo de águas mais rasas apresentam química dominante de $\mathrm{Na}-\mathrm{Ca}-\mathrm{HCO}_{3}$ e $\mathrm{Ca}-\mathrm{Na}-\mathrm{HCO}_{3}$, já o grupo das águas profundas $\mathrm{Ca}-\mathrm{Na}-\mathrm{Cl}$. As amostras foram plotadas no diagrama $\delta \mathrm{D} \times \delta^{18} \mathrm{O}$ juntamente com a GWMG e muitas se posicionaram acima da referida curva (Figura 5.3).

As águas rasas e frescas se localizam sobrepostas ou abaixo da GWMG indicando a participação de processos climáticos. Entretanto, as amostras salinas e salmouras apresentam um enriquecimento no $\delta \mathrm{D}$ e um empobrecimento no $\delta^{18} \mathrm{O}$ se localizando acima da curva da água meteórica global. Os autores concluíram que as águas salinas não representavam um estágio da evolução química com aumento do TDS no decorrer do fluxo, mas sim uma mistura de águas isotopicamente e quimicamente distintas das águas rasas (localizadas abaixo da GWML) e profundas (sinalizadas com o círculo vermelho). Os dados de ${ }^{87} \mathrm{Sr} /{ }^{86} \mathrm{Sr}$ das amostras de salmoura e rocha mostraram forte correlação. Com a combinação dos dados os autores concluíram que as salmouras sofreram um intenso processo de interação água-rocha. Suas assinaturas isotópicas podem refletir ou uma condição climática adversa da atual, paleochuvas em clima mais frio, ou são frutos da interação água-rocha (FRAPE et al., 1984).

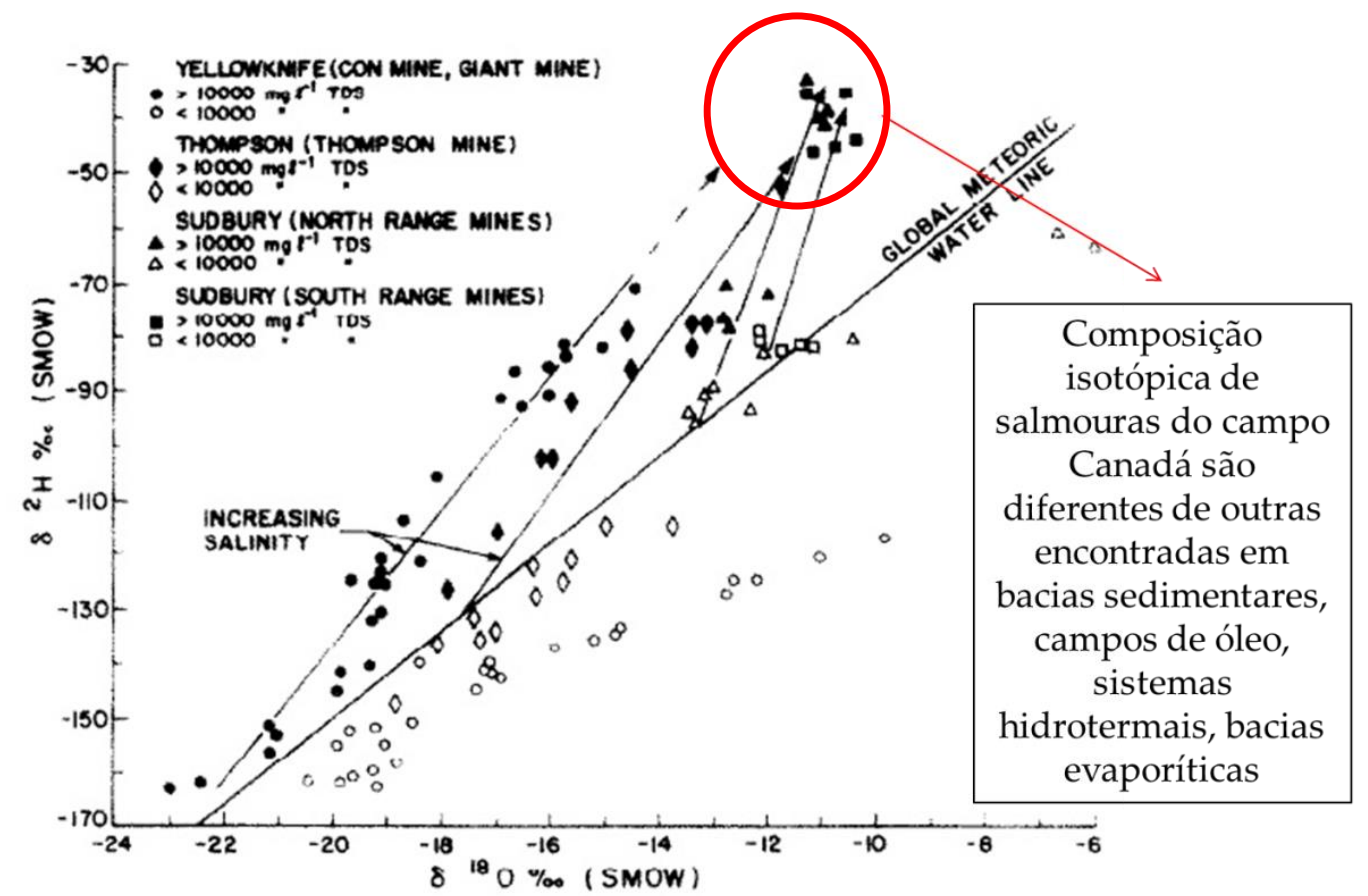

Figura 5.3 - Amostras de água subterrânea de aquífero fraturado do Canadá de diferentes salinidades plotadas no diagrama $\delta \mathrm{D} \times \delta^{18} \mathrm{O}$. As linhas de aumento de salinidade representam águas salinas resultado da mistura de águas rasas e frescas (localizadas abaixo da GWML) e de salmouras profundas (sinalizadas com o círculo vermelho) (FRAPE et al., 1984).

A Figura 5.4 prevê a ocorrência de assinaturas isotópicas de águas subterrâneas acima da GMWG devido ao fracionamento isotópico no processo de hidratação de silicatos. 


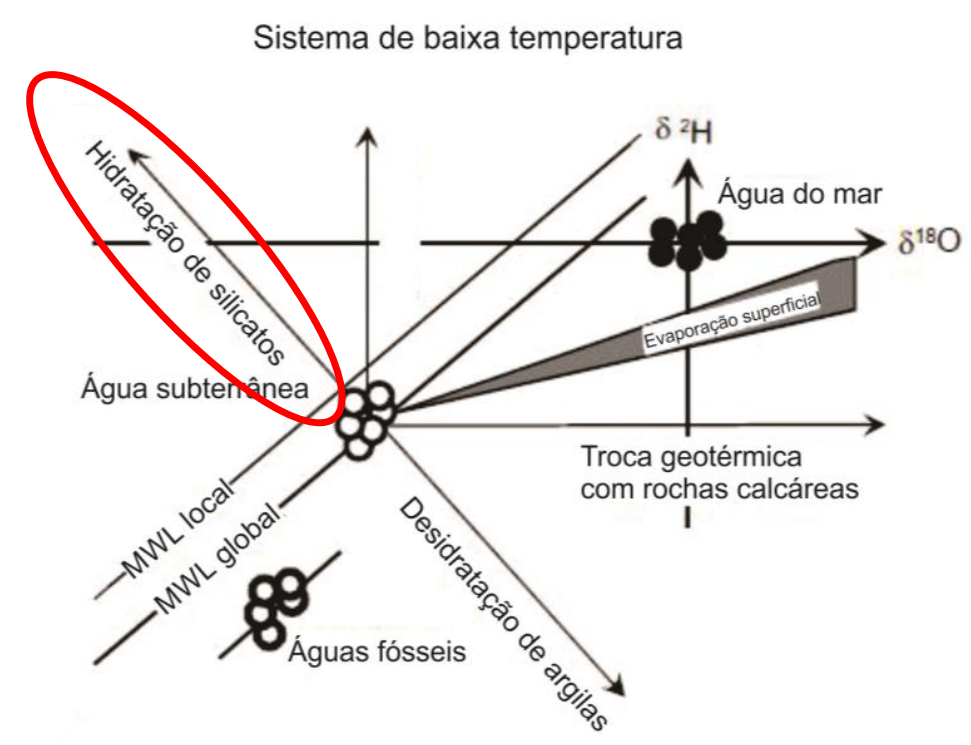

Figura 5.4 - Variações da curva da água meteórica global prevendo o comportamento de águas subterrâneas decorrente do fracionamento isotópico no processo de interação água-rocha (Adaptado de GEYH, 2001).

Os poços analisados no município de Petrolina apresentaram uma característica bastante interessante. Poços relativamente próximos apresentam níveis estáticos, vazões e condutividades elétricas distintas. Indicando que captam água de diferentes famílias de fraturas. Isso sugere que as fraturas na área são pouco conectadas e o que ocorre na região são aquíferos isolados presentes na intercessão de algumas fraturas. Observações das fraturas realizadas na pedreira abandonada situada na BR-407 próximo à sede do município de Petrolina permitem sugerir que existem poucas fraturas horizontalizadas que servem como grandes condutoras e armazenadoras de água.

Tal fato permite concluir que o fluxo subterrâneo é restrito sendo que a água fica em contato com a rocha por um tempo prolongado, o que favorece a interação água-rocha. Os dados de isótopos acima da reta da água meteórica local podem ser devido à interação água-rocha. Neste caso a hidratação dos silicatos, principalmente dos feldspatos nos gnaisses e granitos utilizaria preferencialmente os isótopos de Oxigênio e de Hidrogênio pesados de forma que o sinal isotópico da água residual no aquífero fica progressivamente mais leve.

Outra possibilidade para explicar tal comportamento isotópico é que elas correspondam a recargas antigas através da infiltração de paleo chuvas. $\mathrm{O}$ clima na região é árido com raras chuvas e recarga limitada, as águas subterrâneas podem ter participação de recargas de chuvas que ocorreram em um clima diferente do atual a centenas de anos.

Os dados isotópicos de estrôncio $\left({ }^{87} \mathrm{Sr} /{ }^{86} \mathrm{Sr}\right)$ apontam para uma participação da interação água-rocha nos aquíferos fraturados de Petrolina. Como indicado no referencial teórico (Capítulo 3), a interação água-rocha pode resultar, depois de um tempo suficiente, em um equilíbrio isotópico com relação ao Sr. Esse processo pode ser analisado comparando a razão ${ }^{87} \mathrm{Sr} /{ }^{86} \mathrm{Sr}$ dos minerais da rocha primária; dos minerais secundários localizados nas fraturas, juntas e poros; e da água subterrânea. Quando as rochas são carbonatos, os valores das águas subterrâneas tendem a se igualar aos encontrados para a rocha total, e quando as rochas são silicáticas tendem a se igualar aos valores dos minerais de alteração.

Os dados de ${ }^{87} \mathrm{Sr} /{ }^{86} \mathrm{Sr}$ estão apresentados na Tabela 4.2. Devido a problemas analíticos, não foi possível a análise completa dos dados. Foram coletadas 5 conjuntos de amostras compostos por amostras de água subterrânea e de rocha. Devido a problemas analíticos no 
laboratório, foram analisados somente 3 conjuntos de amostras completos. Os conjuntos são: EM, do poço de monitoramento do Sistema Piloto da Escola Municipal; RKF, do poço de monitoramento do Sistema Piloto da RKF mudas; e 137 que corresponde a um poço antigo bombeado com cata-vento.

O par EM, apesar de ter elevada C.E., não apresentou correlação entre ${ }^{87} \mathrm{Sr} /{ }^{86} \mathrm{Sr}$ da água subterrânea e das rochas, indicando que as águas podem não ter tido interação água-rocha por um período de tempo suficiente para que fosse estabelecido o equilíbrio. Outra explicação é que a água apresente recarga em área com diferente contexto geológico e o sistema de fluxo por fraturas sub-horizontais a coloca em contexto de rochas distintas. O par 137 apresentou uma maior aproximação dos valores tendo uma diferença de 0,00629 indicando uma maior participação da interação água-rocha, apesar de ter o menor valor de condutividade elétrica entre as amostras. Já o par RKF foi o que obteve resultados mais interessantes. O conjunto de amostras do Sistema Piloto da RKF mudas é composto por 3 amostras, uma da água do poço, uma de amostras alteradas coletadas próximo ao poço $\left({ }^{87} \mathrm{Sr} /{ }^{86} \mathrm{Sr}\right.$ em pó de rocha) e uma de amostra fresca coletada a aproximadamente $50 \mathrm{~m}$ do poço em uma cisterna com rocha fresca aflorante $\left({ }^{87} \mathrm{Sr} /{ }^{86} \mathrm{Sr}\right.$ em rocha). Os dados da água subterrânea se aproximam bastante do encontrado para a amostra de rocha alterada, com uma diferença de 0,00063, e não se assemelha aos dados de rocha fresca. Isso mostra que a interação água-rocha ocorreu por um período de tempo suficiente para que houvesse uma troca isotópica entre a água e a rocha durante a hidratação dos silicatos e formação dos minerais de alteração resultando em um equilíbrio isotópico com relação ao Estrôncio (Figura 5.5). Segundo os dados de datação a amostra de água RKF possui aproximadamente 282 anos. As outras 3 amostras datadas nesta dissertação (113, CN e JA) são mais antigas, portanto espera-se que o equilíbrio com relação ao Sr já esteja estabelecido em todas elas.

Tempo de residência da água subterrânea

Interação água-rocha

\section{$\mathrm{Sr}^{87} / \mathrm{Sr}^{86}$}

Rocha sã

Rocha alterada

$0,74111 \pm 1$

Água subterrânea

$<$ L.Q.

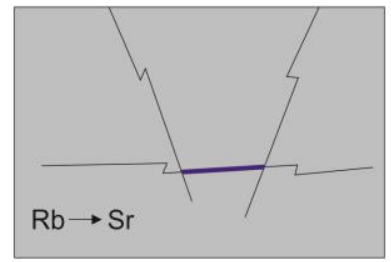

Amostra EM

$$
\text { C.E. }=9,59 \mathrm{mS} / \mathrm{cm}
$$

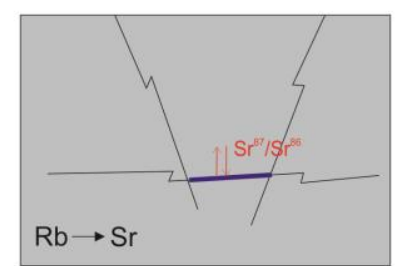

Amostra 137

C.E. $=2,92 \mathrm{mS} / \mathrm{cm}$
$0,76611 \pm 1$

$0,74153 \pm 1$

$0,74216 \pm 1$

Figura 5.5 - Evolução do processo de interação água-rocha nas águas subterrâneas do município de Petrolina com base na análise da razão ${ }^{87} \mathrm{Sr} /{ }^{86} \mathrm{Sr}$. 
O poço de coleta da amostra 137 está localizado sobre as rochas da Faixa Móvel Riacho do Pontal e os de coleta das amostras EM e RKF sobre rochas do Cráton São Francisco. Assim, as análises das razões de estrôncio mostram que o processo de interação água-rocha está presente nas rochas dos 2 contextos geológicos.

Quanto à datação (Tabela 4.3), as amostras apresentaram valores aproximados de idade com Carbono 14 entre 282 e 5.547 anos. Os baixos valores de Trítio reforçam a ausência de recarga recente nas fraturas profundas captadas pelos poços. Não foi possível estabelecer uma relação entre a condutividade elétrica e as idades, mas foi possível observar a relação entre as idades e o $\delta^{13} \mathrm{C}$ com $\mathrm{R}^{2}$ de 0,957 . Quanto mais antigas as águas mais negativo o $\delta^{13} \mathrm{C}$ (Figura $5.6)$.
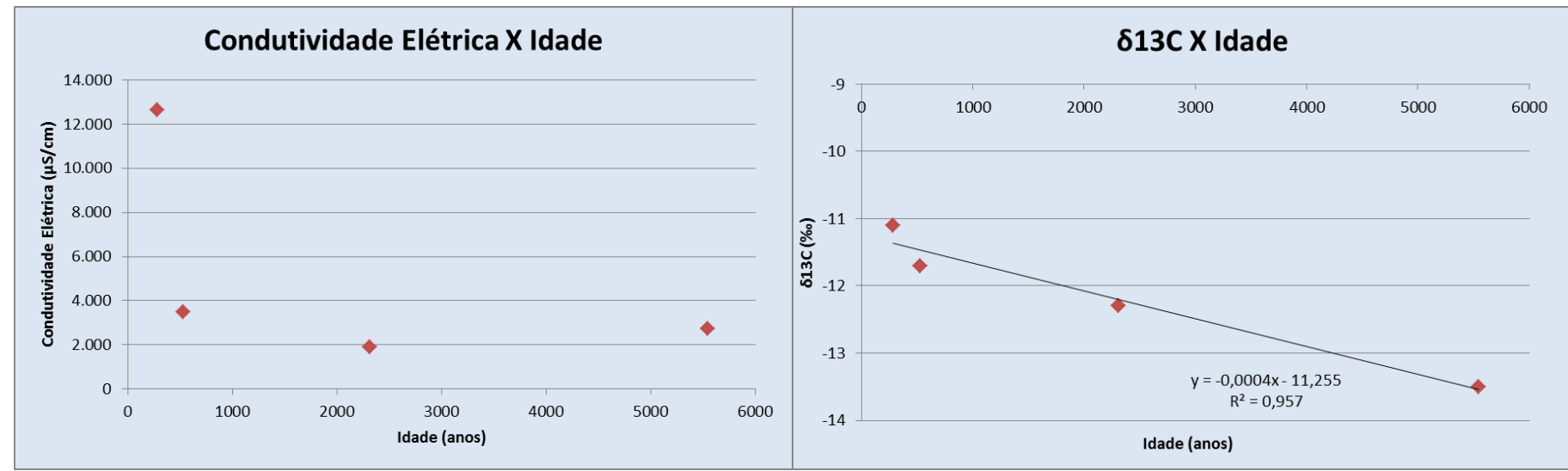

Figura 5.6 - Relação das idades aproximadas obtidas pelo método carbono 14 com a condutividade elétrica e $\operatorname{com} 0 \delta^{13} \mathrm{C}$.

Os resultados das dosagens de Trítio indicam que não há recarga recente, pois os valores são abaixo do limite de detecção do equipamento de medição. Entretanto, estudo realizado no semiárido da Bahia aponta para a existência de variações dos níveis estáticos em poços de monitoramento localizados em aquíferos fraturados (SILVA, 2015). Essas variações são decorrentes de recargas recentes. Assim, os valores reduzidos de Trítio obtidos nas análises da presente dissertação não indicam que não há recarga recente. Elas podem estar ligadas a profundidade da água captada nos poços. As águas de recarga recente, que devem apresentar valores de Trítio maiores, ficam localizadas nas partes mais superficiais dos aquíferos, já as águas desprovidas de Trítio estão armazenadas em porções profundas dos aquíferos e são derivadas de recargas que ocorreram a centenas de anos. Os poços utilizados para coleta de amostras de água para datação provavelmente produzem águas mais antigas a partir de fraturas profundas ou interconectadas a áreas de recarga distantes. Isso influencia na idade das águas obtidas sendo que poços cacimbas escavados em aluviões devem captar águas mais jovens (Figura 5.7). 


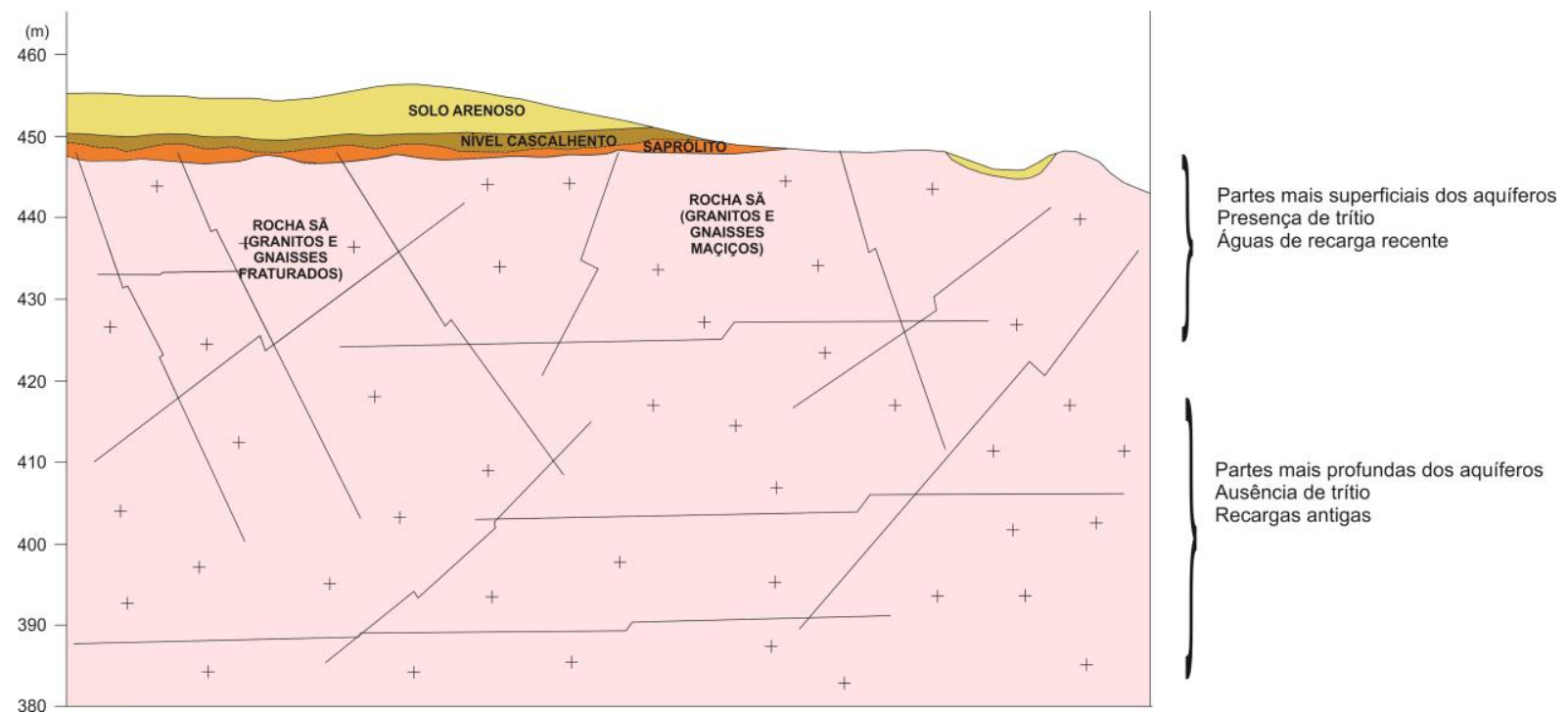

Figura 5.7 - Seção transversal mostrando as prováveis variações nos conteúdos de Trítio das águas subterrâneas de acordo com a profundidade.

A amostragem no canal de irrigação que leva água do Rio São Francisco até as proximidades do povoado de Uruás permitiu confirmar a importância do processo de evaporação no semiárido do nordeste brasileiro. A Figura 5.8 mostra a curva da água residual acentuada observada nas amostras do canal de irrigação. Mostrando nitidamente o enriquecimento em isótopos pesados nas águas residuais do canal com a atuação da evaporação.

As amostras do canal próximas ao Rio São Francisco encontram-se mais próximas da curva da água meteórica global, mas já apresentam uma característica de evaporação em função da barragem da Usina Hidrelétrica de Sobradinho que se localiza a poucos quilômetros a montante de Petrolina. No decorrer do canal a evaporação é intensificada e as amostras tendem a ficar enriquecidas em isótopos pesados se distanciando da curva da água meteórica global e local. A linha de tendência gerada pela curva de evaporação das amostras apresenta a equação exposta no gráfico da Figura 5.8 com $\mathrm{R}^{2}$ elevado. A extrapolação da linha de tendência permite identificar a assinatura isotópica da água antes que o processo de evaporação começasse a atuar, denominada "água inicial” na figura.

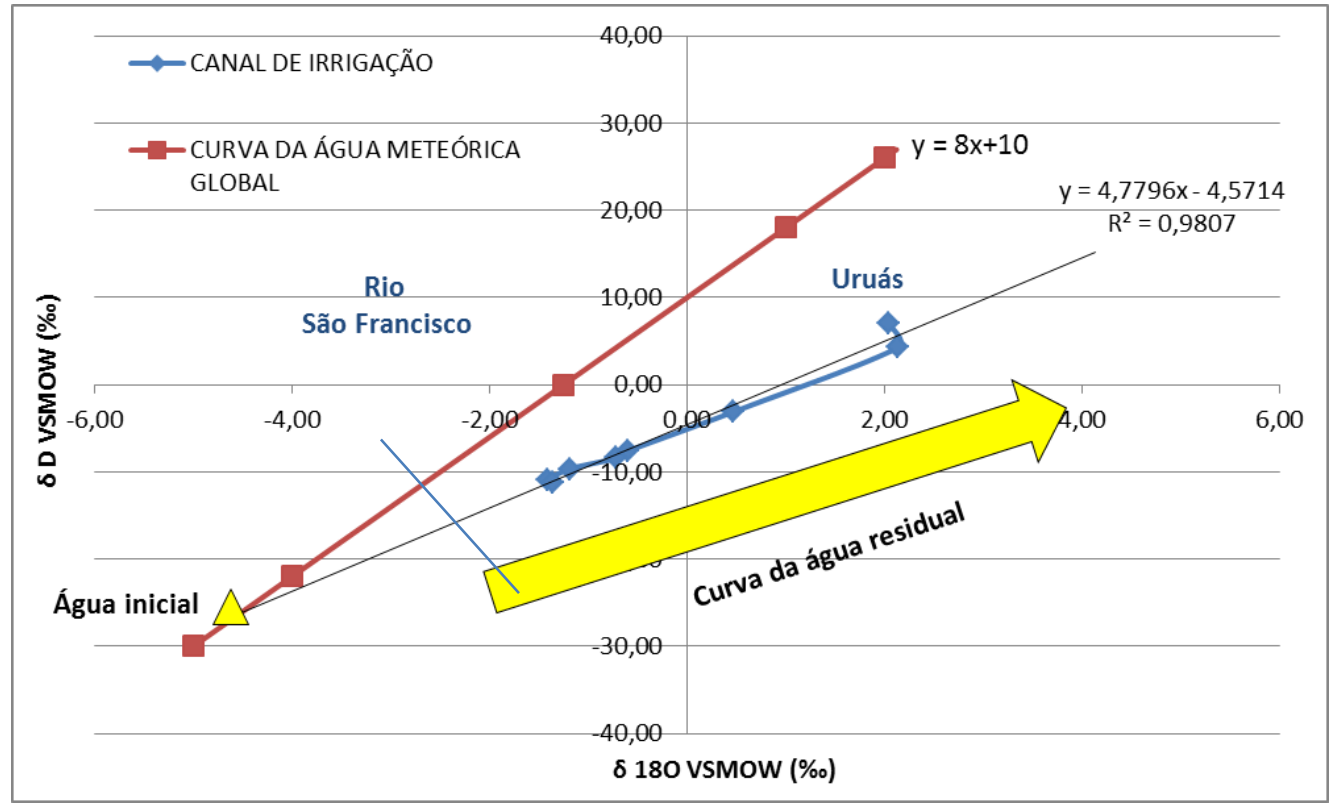

Figura 5.8 - Curva da evaporação para amostras coletadas ao longo do canal de irrigação que liga as águas do Rio São Francisco ao interior do município (proximidades do povoado de Uruás). 
O Sistema Piloto de Recarga Artificial desenvolvido pelo Projeto RECARFRAT foi testado em três sítios descritos na seção 1.5 no capítulo 1 .

A recarga artificial no Sistema Piloto da Escola Municipal não obteve êxito devido a problemas na trincheira de recarga. Em sua escavação foi encontrado um nível de micaxisto com baixa condutividade hidráulica que funcionou como uma barreira hidráulica retardando a chegada da água de recarga na fratura monitorada. Dessa forma, os testes foram suspensos. O acontecimento reforça os cuidados necessários na instalação de sistemas de recarga artificial rasos. A presença de níveis impermeáveis próximos à superfície limita seu funcionamento.

No Sistema Piloto da RKF mudas também houve problemas na construção da trincheira. Esta ficou localizada mais afastada do poço, comparativamente com os outros sistemas piloto, e não foi preenchida adequadamente sendo que além de cascalho foram depositados sedimentos mais finos. Devido a esses condicionantes era esperado que a chegada da recarga artificial fosse mais demorada.

É possível observar na Figura 5.9 que nos períodos de medição os parâmetros isotópicos e físico-químicos mostram variações sem um padrão definido. Sendo que somente nos períodos de pausa das medições (interrompidas durante as madrugadas) o gráfico apresenta retas sem variações. A aleatoriedade das medições não permite que a determinação da chegada da água de recarga artificial seja feita somente com a análise do gráfico. Assim, os dados foram plotados no diagrama $\delta^{18} \mathrm{O}$ x $\delta \mathrm{D}$ (Figura 5.10).

Os dados no diagrama $\delta^{18} \mathrm{O} \times \delta \mathrm{D}$ mostram que a amostra RKF-III-20 apresenta nitidamente características de mistura entre as águas do aquífero e do Rio São Francisco. A RKF-III-20 foi à terceira amostra coletada no dia 27/03/2015 as 9h30 da manhã e não apresenta variações significativas quanto aos parâmetros físico-químicos com relação às amostras próximas a ela. Tal fato confirma a maior sensibilidade dos isótopos na detecção de misturas de águas. Nelson \& Melady (2014) relatam o uso de isótopos de nitrogênio $\left(\delta^{15} \mathrm{~N}\right)$ e análise hidroquímica para monitoramento de sistemas de recarga artificial do tipo ASR em Oregon nos EUA.

O pulso de mistura da água de recarga com a água do aquífero foi bem discreto, sendo observado somente em uma amostra, devido aos problemas construtivos da trincheira de recarga e a grande perda por fluxo lateral nos solos. O sistema Piloto da RKF mudas está localizado mais próximo ao Rio São Francisco e por isso possui solo mais espesso.

Os cálculos descritos por Martinelli et al. (2009) e Araguás (2014) permitem o cálculo da participação de águas com assinaturas isotópicas distintas em uma mistura de 2 componentes através da equação:

$$
Q_{P} \cdot \delta_{P}=Q_{A} \cdot \delta_{A}+Q_{B} \cdot \delta_{B}
$$

Onde, $\mathrm{Q}_{\mathrm{A}}, \mathrm{Q}_{\mathrm{B}}, \mathrm{Q}_{\mathrm{P}}$ representam as contribuições relativas das fases A e B e do produto, respectivamente.

Aplicando a equação aos dados da amostra RKF-III-20, onde ocorre a assinatura isotópica de mistura das águas do aquífero com as do Rio São Francisco, tem-se:

$$
100 \cdot(-24,77)=Q_{A} \cdot(-29,09)+\left(100-Q_{A}\right) \cdot(-16,28)
$$

A água do aquífero contribui com $66,27 \%$ e a água da recarga artificial com 33,73\%, segundo dados de $\delta \mathrm{D}$. E que a água do aquífero contribui com $43,33 \%$ e a água da recarga com 
$56,67 \%$ segundo o $\delta^{18} \mathrm{O}$. Os valores são significativos e as variações são decorrentes de imperfeições ligadas à metodologia. As Figuras 5.9 e 5.10 mostram o monitoramento realizado durante os testes do Sistema Piloto da RKF mudas.

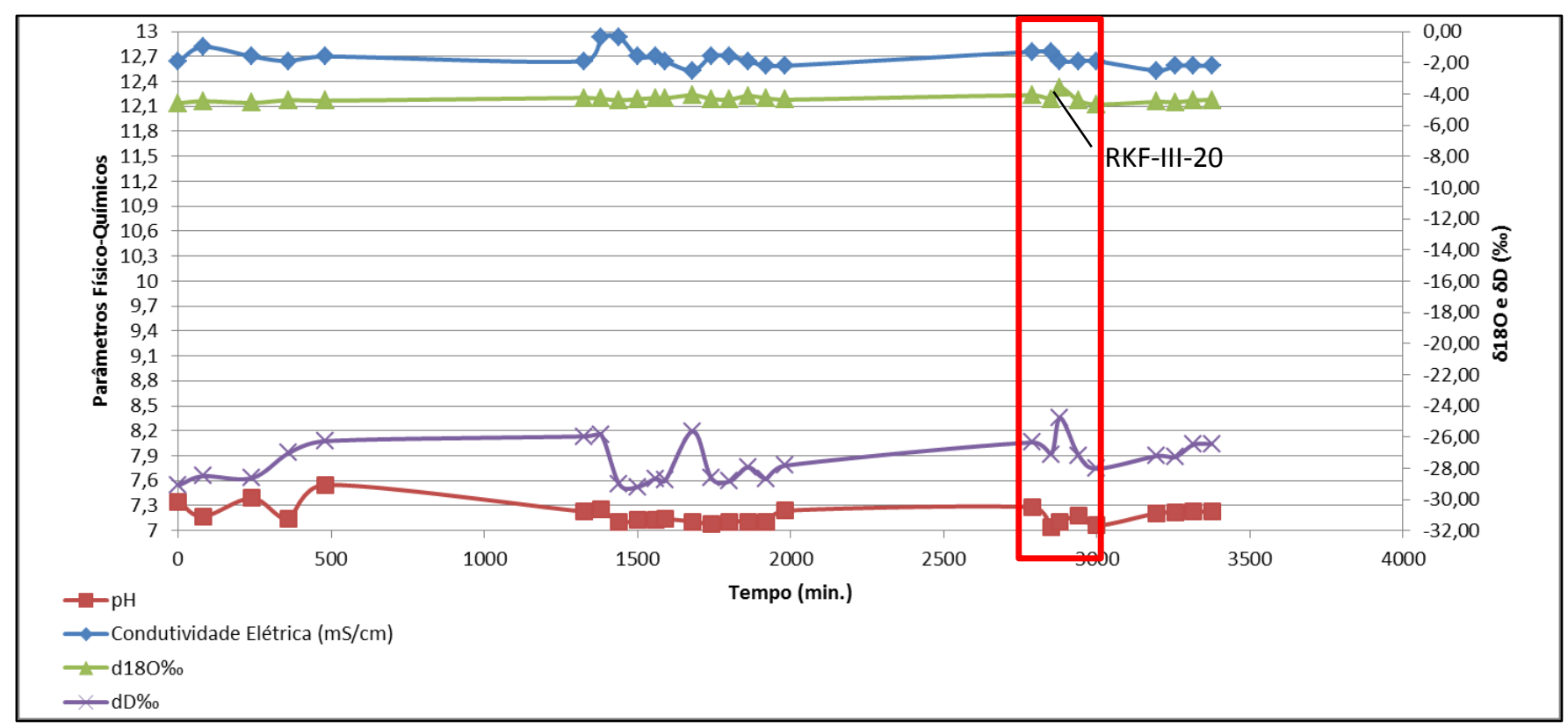

Figura 5.9 - Variação dos parâmetros físico-químicos e isotópicos durante o monitoramento do Sistema Piloto da RKF Mudas. $O$ quadrante vermelho corresponde à amostra RKF-III-20.

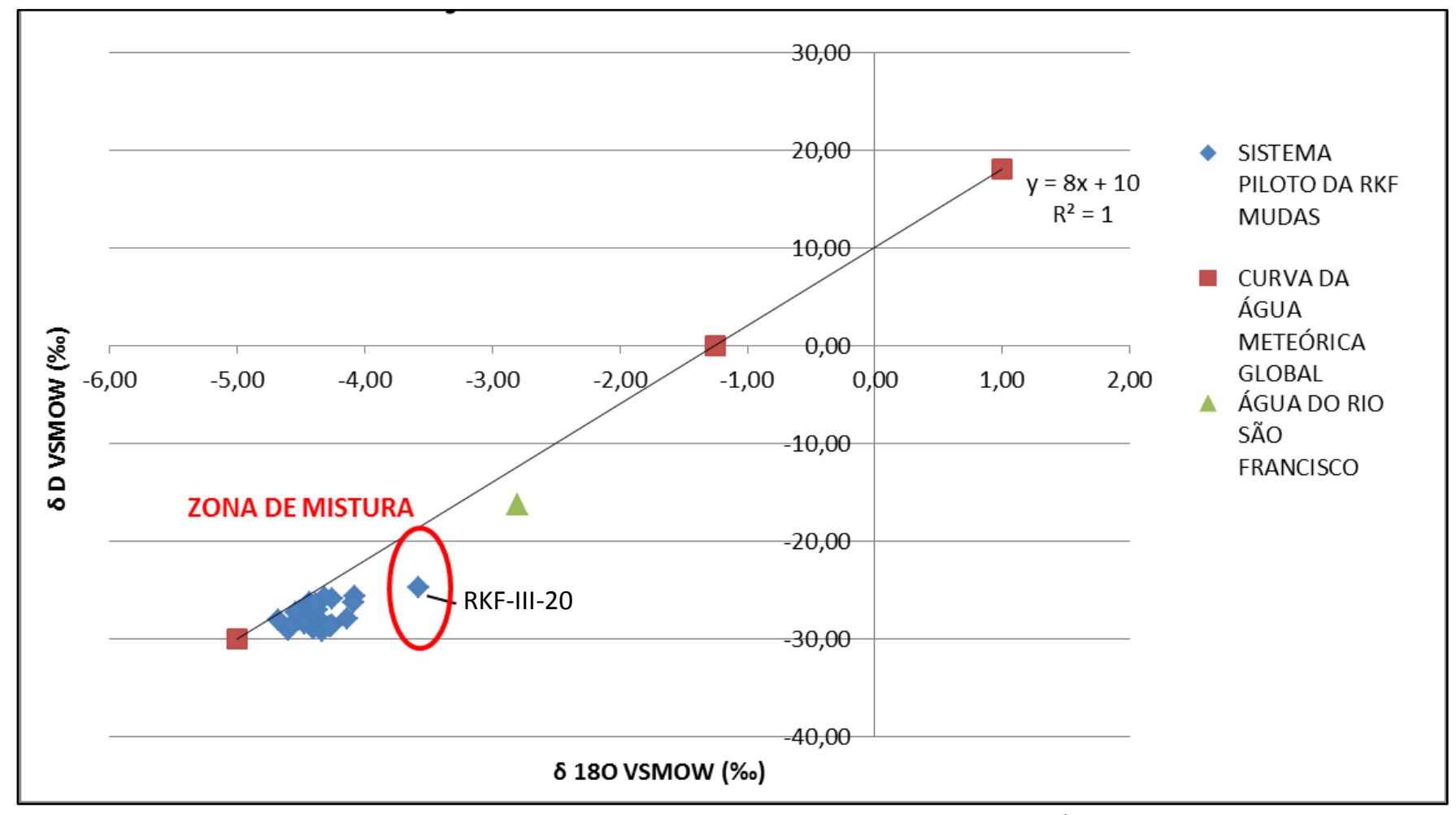

Figura 5.10 - Avaliação do funcionamento do Sistema Piloto da RKF Mudas. O gráfico mostra a assinatura isotópica inicial do aquífero, da água utilizada na recarga e da mistura.

O teste realizado no Sistema Piloto da Fazenda do Jair foi o que apresentou os melhores resultados. Foram injetados 2 pulsos de água tanto do Rio São Francisco quanto do canal de irrigação. As Figuras 5.11 e 5.12 mostram o monitoramento realizado durante os testes do Sistema Piloto da Fazenda do Jair. 


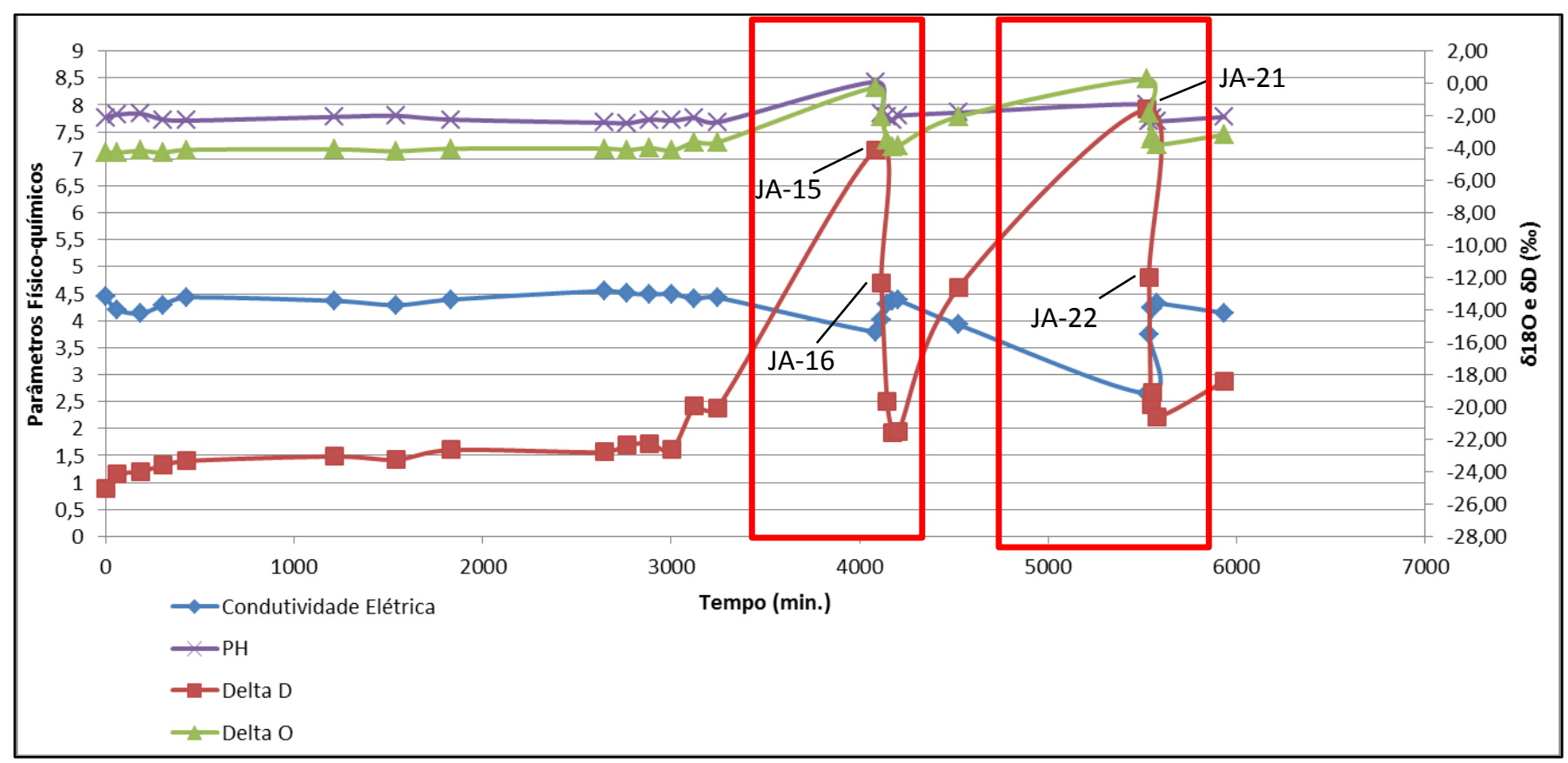

Figura 5.11 - Indicação das alterações nos parâmetros físico-químicos e isotópicos no momento da chegada da água da recarga artificial apontada pela Figura 5.12.

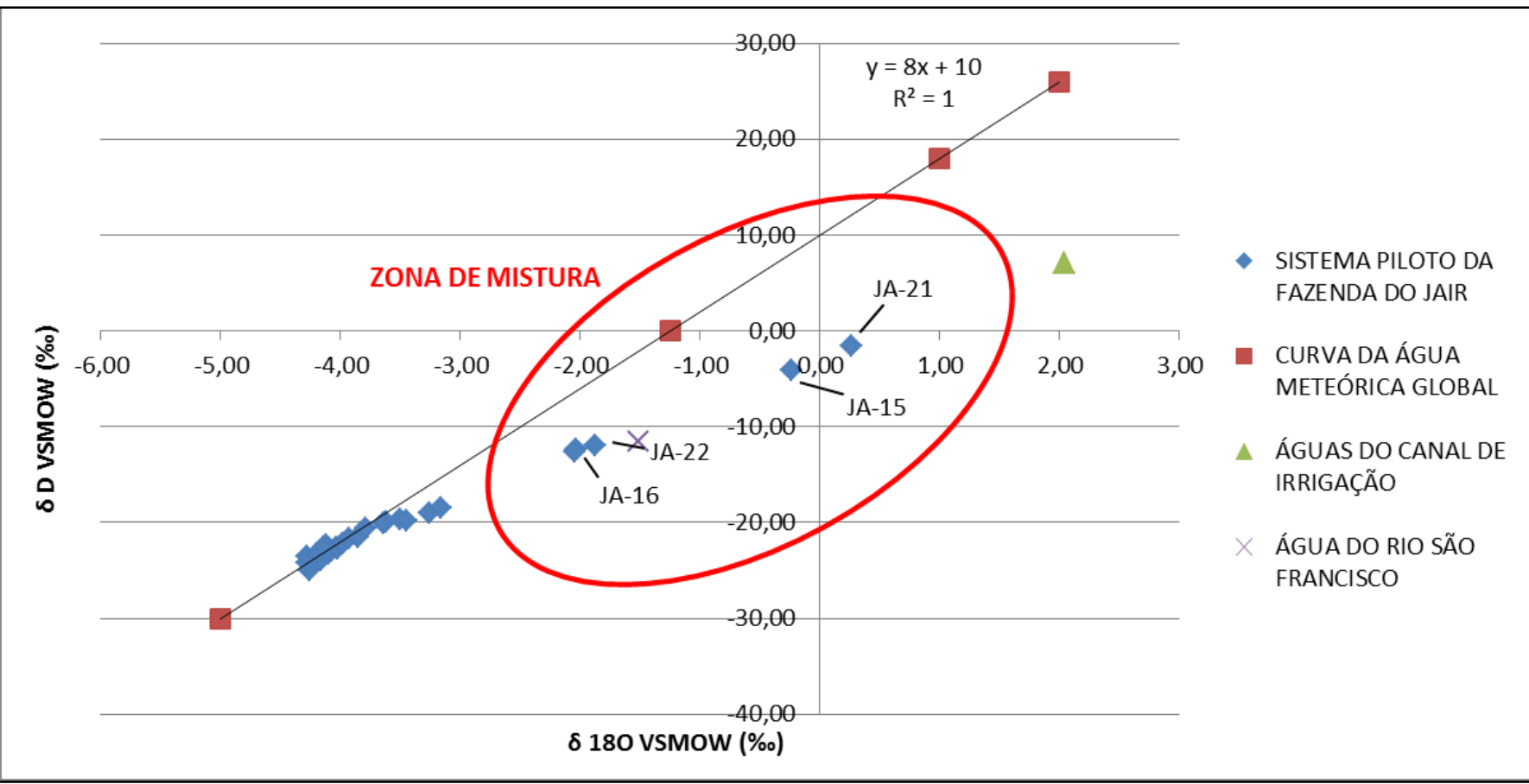

Figura 5.12 - Avaliação do funcionamento do Sistema Piloto da Fazenda do Jair. O gráfico mostra a assinatura isotópica inicial do aquífero, das águas utilizadas na recarga e da mistura.

A análise dos gráficos permite concluir que houve dois momentos de chegada da água de recarga artificial na fratura monitorada. Os parâmetros físico-químicos e os dados isotópicos mostram de maneira bem mais nítida a chegada da recarga comparativamente aos dados do Sistema Piloto da RKF mudas. As amostras JA-15 e JA-16 evidenciam o primeiro momento de chegada da água de recarga; e as amostras JA-21 e JA-22 o segundo momento. As 4 amostras apresentam assinaturas isotópicas de mistura das águas iniciais do aquífero com as águas da recarga artificial (do canal de irrigação e do Rio São Francisco). Não é possível determinar se os momentos são correspondentes ao primeiro ou ao segundo pulso de injeção. Como houve a mistura de 3 fontes, não é possível usar o modelo de mistura de 2 fontes exposto anteriormente. 
Um fato interessante diz respeito à diminuição da condutividade elétrica das águas subterrâneas na chegada da água de recarga artificial. No segundo momento de chegada da água de recarga a condutividade elétrica das águas subterrâneas diminuiu mais do que no primeiro momento. Indicando que sucessivas injeções de água da recarga artificial possam diminuir gradativamente cada vez mais as condutividades elétricas e a salinidades das águas subterrâneas. Esse fato torna viável a aplicação do Sistema Piloto de Recarga Artificial projetado para o fim proposto, diminuir a salinidade das águas subterrâneas.

Dos 3 sítios construídos para teste do sistema piloto de recarga artificial, 2 mostraram-se adequados. Os resultados do Sistema da RKF mudas mostraram a chegada discreta da água de recarga na fratura monitorada pelo poço. A resposta em somente uma amostra pode ter explicação no escape lateral da água no solo, que é mais espesso na área em decorrência da maior proximidade com o Rio São Francisco. Pode ser que essa água tenha infiltrado em outra fratura diferente da monitorada e pode ser que um maior volume de água tenha chegado à fratura após o fim do monitoramento. Os testes no Sistema da Escola Municipal não foram concluídos devido à presença de nível de micaxisto na base na trincheira de recarga. O Sistema do Jair foi o mais efetivo e obteve avaliação positiva.

Os resultados permitem concluir que o sistema piloto de recarga artificial possui viabilidade hidráulica, ou seja, é possível que a água de recarga artificial chegue aos aquíferos fraturados e diminua sua salinidade. Entretanto, alguns aspectos importantes devem ser observados para a efetividade da recarga como: a presença de camadas impermeáveis próximas à superfície e principalmente próximas a trincheira de recarga; a trincheira deve ser preenchida somente com cascalho para garantir a elevada condutividade hidráulica do meio; a água de injeção deve conter baixo conteúdo de sedimentos em suspensão para evitar a colmatação nas paredes e no fundo da trincheira e a trincheira deve ser escavada até o contato solo-rocha.

Já a aplicabilidade no semiárido nordestino está atrelada ao volume de água que será disponibilizado para infiltração. O objetivo principal da aplicação do sistema é diminuir a salinidade das águas subterrâneas a fim de aumentar suas possibilidades de uso e, para tal, deve ser infiltrada uma quantidade de água suficiente para que isso ocorra. Freeze \& Cherry (1979) classificam águas com TDS < $1.000 \mathrm{mg} / \mathrm{L}$ como doces. A portaria CONAMA 396/2008, que dispõe sobre a classificação e as diretrizes ambientais para o enquadramento das águas subterrâneas, define que o valor máximo permitido para consumo humano para TDS é de 1.000 $\mathrm{mg} / \mathrm{L}$. Dessa forma, se as águas subterrâneas atingissem valores de TDS menores que 1.000 $\mathrm{mg} / \mathrm{L}$ elas seriam consideradas doces e isso ampliaria suas possibilidades de uso.

Tomando como base o Sistema Piloto da Fazenda do Jair, foi realizado um cálculo estimativo do volume de água que seria injetado numa trincheira localizada no semiárido nordestino de maneira natural com a água da chuva. Considerando uma cobertura de telhado de tamanho 10 x $10 \mathrm{~m}\left(100 \mathrm{~m}^{2}\right)$ e que a precipitação média anual no semiárido nordestino, segundo a SUDENE, seja igual ou inferior a $800 \mathrm{~mm}$. Em uma visão otimista (com precipitação média anual de $800 \mathrm{~mm}$ ), por ano precipitará sobre esta cobertura $8.000 \mathrm{~L}$ de água de chuva. No teste do Sistema do Jair foram infiltrados $39.000 \mathrm{~L}$ de água na trincheira, o que simulou a chuva de aproximadamente 4 anos e 10 meses, e foram observados 2 pulsos de chegada. No primeiro a condutividade elétrica abaixou de 4,404 para $3,792 \mathrm{mS} / \mathrm{cm}$ (uma diminuição de 13,89\%) e no segundo ela rebaixou de 4,304 para $2,652 \mathrm{mS} / \mathrm{cm}(38,38 \%)$. Isso mostra que sucessivas infiltrações podem diminuir gradativamente cada vez mais a salinidade das águas subterrâneas. Tomando esses valores como base para uma estimativa muito simplificada, se a cada 5 anos de 
chuva a condutividade elétrica reduzir $1,652 \mathrm{mS} / \mathrm{cm}$, para um valor inicial de C.E. de 4,5 mS/cm (valor inicial do poço do Sistema do Jair), em aproximadamente 10 anos os valores estarão abaixo de $1,7 \mathrm{mS} / \mathrm{cm}$ que equivale, em TDS, a valores abaixo de $1.000 \mathrm{mg} / \mathrm{L}$. Ou seja, a água passa a ser considerada doce. Porém, além disso a água deve ter os outros parâmetros químicos citados na referida portaria da CONAMA dentro dos intervalos permitidos (Tabela 5.1).

Nas regiões de secas mais críticas do nordeste, aonde a precipitação média anual chega a ser da ordem de $400 \mathrm{~mm}$, os valores devem ser dobrados para um telhado de mesmas dimensões $\left(100 \mathrm{~m}^{2}\right)$ e para condutividade elétrica inicial de $4,5 \mathrm{mS} / \mathrm{cm}$. Após 20 anos do início do funcionamento do sistema o TDS atingirá valores abaixo de $1.000 \mathrm{mg} / \mathrm{L}$ (Tabela 5.1).

Tabela 5.1 - Estimativa do tempo necessário para que a água subterrânea de Petrolina seja considerada doce com o Sistema Piloto funcionando de maneira natural com a água da chuva.

\begin{tabular}{|c|c|c|c|c|c|c|}
\hline Cenário & $\begin{array}{c}\text { Precipitação } \\
\text { média anual }\end{array}$ & $\begin{array}{c}\text { Volume de água } \\
\text { da chuva no } \\
\text { telhado por ano }\end{array}$ & $\begin{array}{c}\text { C.E. } \\
\text { inicial }\end{array}$ & $\begin{array}{c}\text { Tempo } \\
\text { (anos) }\end{array}$ & $\begin{array}{c}\text { Diminuição } \\
\text { da C.E. }\end{array}$ & $\begin{array}{c}\text { Tempo para } \\
\text { que a água se } \\
\text { torne doce } \\
\text { (anos) }\end{array}$ \\
\hline Otimista & $800 \mathrm{~mm}$ & $8.000 \mathrm{~L}$ & $4,5 \mathrm{mS} / \mathrm{cm}$ & 5 & $1,652 \mathrm{mS} / \mathrm{cm}$ & 10 \\
\hline Pessimista & $400 \mathrm{~mm}$ & $4.000 \mathrm{~L}$ & $4,5 \mathrm{mS} / \mathrm{cm}$ & 10 & $1,652 \mathrm{mS} / \mathrm{cm}$ & 20 \\
\hline
\end{tabular}

O sistema pode apresentar resultados se aplicado no semiárido nordestino, entretanto em longo prazo. Levando em consideração que haverá perdas por evaporação no transporte da água dos telhados até a trincheira, que há perda por fluxo lateral no solo e no contato solo-rocha e que as chuvas apresentam variações espaciais e não abrangem grandes áreas, estima-se que respostas satisfatórias sejam obtidas em 15 a 20 anos, para uma estimativa de $800 \mathrm{~mm}$ de precipitação média anual; e entre 25 e 30 anos, nas áreas mais críticas com cerca de $400 \mathrm{~mm}$ de precipitação média anual.

Essa estimativa foi feita de maneira simplificada e o tempo sugerido para que os valores de TDS diminuam a ponto de aumentar os possíveis usos das águas subterrâneas pode variar se os parâmetros utilizados variarem. Por exemplo, foi utilizada uma área de cobertura de $100 \mathrm{~m}^{2}$ de área para os cálculos, se for canalizada água de vários telhados ou de um telhado de maiores dimensões a diminuição da salinidade será mais rápida e o tempo para que os resultados sejam alcançados irá diminuir. Da mesma forma, se a condutividade elétrica inicial da água subterrânea for maior o processo de recarga artificial irá demandar mais tempo para que os valores de TDS atinjam valores menores que $1.000 \mathrm{mg} / \mathrm{L}$.

A determinação dos valores de salinidade necessários para ampliar os usos das águas subterrâneas depende das características hidroquímicas de cada poço e de quais íons são predominantes na água. No município de Petrolina, de forma geral, as águas subterrâneas são utilizadas somente para dessedentação de animais e irrigação de pequenas áreas. A previsão é que a água subterrânea, após 15 a 30 anos da implantação dos sistemas de recarga artificial e diminuição da salinidade, sirva para usos gerais como dessedentação de outros animais mais sensíveis, higiene e recreação. É muito difícil que as águas mais salinas cheguem a padrões de qualidade que permitam sua utilização para consumo humano. 


\section{CAPÍTULO 6}

\section{CONCLUSÕES E RECOMENDAÇÕES}

O município de Petrolina está localizado no semiárido nordestino sobre rochas do embasamento cristalino onde os aquíferos são fraturados e possuem águas com elevadas salinidades. O déficit hídrico persiste há anos na região onde as águas superficiais são escassas e fortemente submetidas a elevadas taxas de evaporação. A elevada salinidade das águas subterrâneas restringe fortemente suas possibilidades de uso pela população.

As elevadas salinidades das águas subterrâneas acometem vários locais do semiárido do nordeste brasileiro. Em muitos deles é realizado um tratamento prévio dessas águas para que elas possam ser utilizadas pela população. Existem técnicas que permitem o uso das mesmas. Nos estados da Bahia e de Pernambuco os dessalinizadores são a técnica mais utilizada.

As análises das águas subterrâneas do município de Petrolina auxiliaram na ampliação dos conhecimentos sobre os aquíferos fraturados no semiárido nordestino suas principais características e peculiaridades. Os dados coletados permitiram um melhor entendimento de aspectos sobre a recarga dos aquíferos, o processo de interação água-rocha e a causa das altas salinidades encontradas nas águas subterrâneas.

Os dados de isótopos estáveis de hidrogênio e oxigênio obtidos no canal de irrigação confirmaram as elevadas taxas de evaporação encontradas no semiárido nordestino e corroboram com os dados climáticos da região. $\mathrm{O}$ vento praticamente constante, as altas temperaturas e a intensa radiação solar fazem com que grandes quantidades de água superficial estejam sendo constantemente evaporadas. Por isso, a importância da recarga artificial que pode ser utilizada tanto para armazenamento de água nas porções menos salinas dos aquíferos, quanto para diminuição da salinidade das águas nas porções com maiores TDS.

A recarga recente no semiárido nordestino é limitada devido à escassez e irregularidade das chuvas associado a altas temperaturas e elevada taxa de evaporação, como mostrado pelas análises isotópicas do canal de irrigação.

A caracterização isotópica regional mostrou que as águas presentes nos aquíferos de Petrolina se localizam acima da curva da água meteórica global e local no gráfico $\delta \mathrm{D}$ versus $\delta^{18} \mathrm{O}$ e ocorrem alinhadas formando uma linha denominada no presente trabalho de "linha da água subterrânea de Petrolina” (Figura 5.2). Diferentemente das análises das águas superficiais do canal de irrigação, que mostraram enriquecimento em isótopos pesados devido ao processo de evaporação; as análises das águas subterrâneas mostraram enriquecimento em isótopos leves. Isso indica que os processos climáticos superficiais, como a evaporação, não possuem influência nas características isotópicas das águas subterrâneas. Existem 3 hipóteses para explicar o enriquecimento em isótopos leves das águas subterrâneas do município de Petrolina: recarga por paleo chuvas; processo de interação água rocha; ou a ação conjunta desses dois fatores.

A hipótese da recarga por paleo chuvas se baseia no fato de que o clima na região é árido com raras chuvas e recarga limitada. As águas subterrâneas podem ter participação de recargas de chuvas que ocorreram em um clima diferente do atual a centenas de anos.

Já a hipótese da interação água-rocha se baseia no fato de que a circulação de água nos meios fraturados do município de Petrolina é restrita e as fraturas são pouco conectadas o que 
restringe o fluxo nos aquíferos. O fluxo restrito permite que as águas subterrâneas permaneçam longos períodos de tempo em contato com as rochas nas fraturas. O que aconteceria é que no processo de hidratação dos silicatos, principalmente dos feldspatos nos gnaisses e granitos, os mesmo assimilariam preferencialmente os isótopos pesados e as águas ficariam enriquecidas em isótopos leves.

A terceira e última hipótese é que ambos os fatores, interação água-rocha e recarga por paleo chuvas, atuem de maneira conjunta para resultar nas assinaturas isotópicas atuais das águas subterrâneas.

O processo de interação água-rocha foi evidenciado em três pontos expostos na presente dissertação: os dados de estrôncio, de hidroquímica e a caracterização isotópica regional. Os dados de ${ }^{87} \mathrm{Sr} /{ }^{86} \mathrm{Sr}$ mostram que o processo de interação água-rocha existe nos aquíferos fraturados de Petrolina em graus variados tanto nas rochas do Cráton São Francisco quanto nas rochas da Faixa Móvel Riacho do Pontal. A sequência de amostras EM -> 137 -> RKF representa um aumento progressivo no tempo de residência das águas subterrâneas e da atuação do processo de interação água-rocha (Figura 5.5). A hidroquímica também indica uma evolução na composição química das águas subterrâneas de acordo com suas condutividades elétricas que outros exemplos na literatura apontam que seja resultado de interações água-rocha (solubilidade de minerais, hidratação de silicatos, neoformação de argilominerais, dentre outros). Os dados apresentados permite considerar que a assinatura isotópica acima da curva da água meteórica global pode ser além da participação de paleo chuvas, resultado de interação água-rocha pela hidratação de silicatos. Portanto, com o conjunto de dados existentes é possível concluir que o processo de interação água-rocha existe nos aquíferos fraturados de Petrolina e em graus variados, tanto nos aquíferos fraturados localizados no Cráton São Francisco, quanto nos localizados na Faixa Móvel Riacho do Pontal.

A seção elaborada com base em seis poços presentes na Fazenda do Sr. Jair (Figura 4.15) juntamente com as análises de fraturas na pedreira abandonada mostra que as águas infiltram em sistemas de fraturas isolados. Esses sistemas de fraturas são conectados por extensas fraturas sub-horizontais profundas. Silva (2015) mostra a importância das fraturas sub-horizontais na interconexão de sistemas de fraturas no semiárido do estado da Bahia.

Alguns dados apresentados nessa dissertação podem contribuir para a ampliação dos conhecimentos sobre a causa das elevadas salinidades observadas nas águas subterrâneas dos aquíferos fraturados do semiárido brasileiro. O que se observa é que um conjunto de fatores tem influência nas altas salinidades encontradas, como já expostos no Capítulo 3. São eles: recarga restrita; solos pouco lixiviado e ricos em elementos alcalinos e alcalinos terrosos; clima (elevadas temperaturas, taxa de evaporação e irradiação solar aliado a chuvas escassas); relevo plano; característica das fraturas (baixa conectividade); e processo de interação água-rocha.

Acredita-se que o enriquecimento em sais possa ocorrer tanto na superfície quanto em profundidade nas fraturas. Em superfície o relevo plano faz com que as águas das chuvas fiquem empossadas e sofram evaporação o que enriquece a água residual em sais. Além disso, as águas percolam pelos solos, enriquecidos em sais, e carreiam parte desses sais. Sendo assim, quando infiltram nas fraturas as águas já estão com certa salinidade. Complementarmente a isso, nas fraturas o longo tempo de residência das águas subterrâneas permite que a interação água-rocha contribua nessa elevada salinidade.

Os dados obtidos para as amostras de Petrolina permitem concluir que a causa da elevada salinidade das águas está ligada predominantemente a processos superficiais com influência do 
enriquecimento em sais nos solos e do clima (elevada taxa de evaporação). O processo de interação água-rocha pode contribuir, mas em menor proporção comparado com os processos superficiais.

A salinidade das águas (expressa pela condutividade elétrica) não possui uma relação explícita com as idades, nem com os dados de ${ }^{87} \mathrm{Sr} /{ }^{86} \mathrm{Sr}$ que são dados que refletem indiretamente o tempo de residência das águas subterrâneas e por isso estão ligados a interação água-rocha. Os dados da hidroquímica que mostram que a condutividade elétrica possui forte correlação com o cloro, mas baixa correlação com o bicarbonato também reforçam que o processo de interação água-rocha possui participação limitada no enriquecimento em sais das águas subterrâneas, conforme apresentado por Andrade \& Leal (2010).

Os solos da área são pouco evoluídos e são enriquecidos em elementos alcalinos e alcalinos terrosos. Foram observados nos trabalhos de campo vertissolos, planossolos, cambissolos e subordinadamente latossolos. Como o relevo é plano, as precipitações se acumulam na superfície onde os íons são dissolvidos. A evaporação deixa a água residual concentrada em íons. Quando ocorre infiltração a água já apresenta certo enriquecimento em sais. Posteriormente nos aquíferos o processo de interação água-rocha pode contribuir para o maior enriquecimento em sais. Entretanto, estima-se que o enriquecimento a partir dos solos seja predominante.

Testes foram realizados com os sistemas piloto de recarga artificial elaborados pelo Projeto RECARFRAT. A aplicação dos sistemas piloto visa à diminuição da salinidade das águas subterrâneas do município de Petrolina aumentando assim suas possibilidades de usos. Os sistemas não pretendem ampliar a oferta de água subterrânea até porque não existe sobrexplotação dos aquíferos na região.

Os sistemas são viáveis hidraulicamente, contudo é necessário um volume considerável de água para que as salinidades diminuam a ponto de ampliar as possibilidades de uso das águas subterrâneas. Portanto, os resultados são esperados em um longo período de tempo após a implantação dos mesmos. Estimativa simplificada foi feita para dois cenários distintos com padrões definidos com base nos dados do Sistema Piloto da Fazenda do Jair para uma área de cobertura (telhado para coleta de água da chuva) de $100 \mathrm{~m}^{2}$ e uma condutividade elétrica inicial de $4,5 \mathrm{mS} / \mathrm{cm}$. Levou-se em consideração que se as águas atingissem valores de TDS inferiores a $1.000 \mathrm{mg} / \mathrm{L}$ elas seriam consideradas doces e isso ampliaria suas possibilidades de uso. $\mathrm{O}$ cenário otimista aponta uma precipitação média anual de $800 \mathrm{~mm}$ e que salinidades abaixo de $1.000 \mathrm{mg} / \mathrm{L}$ sejam atingidas entre 15 e 20 anos. O cenário pessimista aponta para $400 \mathrm{~mm}$ de precipitação média anual e um tempo em torno de 25 a 30 anos.

O tempo apresentado foi calculado com base em uma estimativa muito simplificada elaborada com parâmetros definidos. Variações nesses parâmetros poderão alterar o tempo calculado. Por exemplo, foi observado nos testes do Sistema Piloto da Fazenda do Jair que sucessivas injeções de água da recarga artificial diminuem gradativamente cada vez mais as condutividades elétricas das águas subterrâneas. Isso não foi levado em conta na estimativa simplificada e pode diminuir o tempo calculado quando o sistema for aplicado.

É importante que os poços de monitoramento dos Sistemas Piloto de Recarga Artificial sejam constantemente bombeados a fim de ativar a circulação de água no aquífero, criando espaço para entrada das águas e ampliando a efetividade da recarga artificial. Moradores da região de Petrolina relatam que poços construídos na década de 1960 com bombeamento ao longo dos anos, apresentaram uma diminuição da salinidade das águas. Estudos realizados no 
semiárido de estado da Bahia não chegaram a conclusões definitivas sobre a relação da diminuição da salinidade das águas com o bombeamento constante. Na ocasião do experimento, metade das amostras aumentou e metade diminuiu o TDS (ANDRADE \& LEAL, 2010). Apesar dos dados inconclusivos é importante que haja a ativação da circulação de água nos aquíferos para que ocorra renovação das águas subterrâneas.

O monitoramento da chegada das águas de recarga artificial nos aquíferos foi feito utilizando parâmetros físico-químicos (medidos in situ) e isótopos estáveis de oxigênio e hidrogênio (analisados em laboratório). O monitoramento por isótopos ambientais foi satisfatório assim como com as medições de parâmetros físico-químicos (C.E., pH e Eh). O primeiro método é mais sensível na detecção da chegada da água de recarga (mistura), apesar de possuir maior custo e precisar ser feito em laboratório. Já o segundo é mais barato e pode ser aplicado em campo. Os dados isotópicos oriundos do monitoramento do Sistema Piloto da RKF Mudas mostraram resultados indicativos de mistura da água do aquífero com a água de recarga artificial, porém as análises dos parâmetros físico-químicos não mostraram variações significativas.

Não se espera que com a aplicação dos Sistemas Piloto de Recarga Artificial as águas subterrâneas atinjam os limites de potabilidade e possam ser utilizadas para fins muito restritivos como o consumo humano. Entretanto, espera-se que suas possibilidades de uso sejam ampliadas em longo prazo. Atualmente as águas subterrâneas são utilizadas em proporções muito pequenas, comparativamente com as águas superficiais, e somente para dessedentação de bodes e cabras e para irrigação de pequenas áreas. Espera-se que com a aplicação dos sistemas piloto em longo prazo as águas subterrâneas possam ser utilizadas para dessedentação de outros animais como bois, vacas e porcos; para higiene como uso em vasos sanitários, limpeza de casas e banho; e para recreação.

As respostas obtidas com a aplicação dos sistemas piloto são locais, pois a conexão entre as fraturas é limitada nos aquíferos fraturados de Petrolina. Sendo assim, não existe um fluxo regional expressivo. Uma possibilidade de aplicação real dos sistemas é pelo poder público. A implantação dos mesmos em pontos estratégicos do semiárido brasileiro poderia em longo prazo oferecer água de melhor qualidade para a população e ampliar suas possibilidades de renda como, por exemplo, permitindo a ampliação da pecuária, com a criação de outros animais; e a própria ampliação da agricultura, com maior oferta de água para irrigação. Políticas públicas de longo prazo estão mostrando sua importância no combate à seca no nordeste do Brasil.

É imprescindível que após a implantação dos sistemas piloto sejam realizadas análises hidroquímicas completas periódicas nas águas subterrâneas a fim de se analisar a potabilidade das mesmas. Além da salinidade das águas os outros íons devem ser analisados para se determinar com precisão os usos possíveis das águas. Outro ponto importante após a implantação dos sistemas é o bombeamento constante dos poços de monitoramento a fim de ativar a circulação de água nos aquíferos e abrir espaço para a entrada da água de recarga.

Existem questões que ainda não estão totalmente esclarecidas e que para tal necessitam de mais estudos. A seguir serão citadas algumas recomendações para estudos posteriores:

- Monitoramento dos Sistemas Piloto de Recarga Artificial de maneira natural somente com a infiltração de água da chuva;

- Realização de mapeamento geológico detalhado da área para um maior conhecimento dos tipos petrográficos e das estruturas rúpteis o que pode auxiliar na compreensão do fluxo de água nos aquíferos e na locação de novos poços; 
- Realização de estudos petrográficos e geoquímicos em rocha para detectar minerais que possivelmente sejam fonte de cloro e outros íons para as águas subterrâneas;

- Realização de levantamentos geofísicos com métodos de análise em profundidade. As observações de campo permitiram notar a presença de extensas fraturas sub horizontais em profundidade que serviriam como grandes condutoras e armazenadoras de água. A análise geofísica em profundidade ajudaria a esclarecer essas questões assim como as características de confinamento dos aquíferos;

- Análises detalhadas dos perfis de solos com análises geoquímicas. Para estudar o possível enriquecimento em alcalinos e alcalinos terrosos dos solos, a disponibilidade de íons e a real participação dos mesmos no enriquecimento em sais das águas subterrâneas;

- Datação de mais amostras de águas subterrâneas com diferentes salinidades para se identificar a influência do tempo de residência com a salinização;

- Datação de amostras de água subterrânea captadas em diferentes profundidades com o método do trítio para identificar recarga recente em níveis rasos;

- Aprofundar os estudos nas possíveis mudanças nas assinaturas isotópicas das águas subterrâneas em função da alteração das rochas nas fraturas com a hidratação de silicatos;

- Ampliar os estudos isotópicos no canal de irrigação a fim de se tentar determinar uma taxa de evaporação natural para a região;

- Identificar a origem do cloro e do bromo presente em altas concentrações nas águas subterrâneas com maiores condutividades elétricas;

- Estudos de outras possíveis aplicações de métodos de recarga artificial na área como, por exemplo, para armazenamento de água da chuva em porções menos salinas dos aquíferos;

- Aprofundar os estudos das razões de ${ }^{87} \mathrm{Sr} /{ }^{86} \mathrm{Sr}$ em rocha e nas águas subterrâneas e verificar se há correlação entre os dados obtidos e as idades das rochas.

A ampliação do conhecimento sobre os aquíferos fraturados da região semiárida brasileira é de extrema importância, pois o uso das águas subterrâneas pode servir de auxílio no enfrentamento dos problemas decorrentes da escassez de água que a décadas acomete a população. Espero que essa dissertação sirva de auxílio e amplie os horizontes para que novos estudos sejam realizados nesse sentido. 


\section{REFÊNCIAS BIBLIOGRÁFICAS}

ABERBACH, S.H. Review of artificial ground-water recharge in the Coastal Plain of Israel. International Assoc. Sci. Hydrology Bull., v. 12, n 1, pag. 65-77, 1967.

AGÊNCIA NACIONAL DE ÁGUAS (Brasil) (1). Atlas Brasil: Abastecimento Urbano de Água: Panorama Nacional. Vol. 1. 2010. 72 p. Brasília.

AGÊNCIA NACIONAL DE ÁGUAS (Brasil) (2). Conjuntura dos recursos hídricos no Brasil: Informe 2014. 2015a. 105 p. Brasília.

AGÊNCIA NACIONAL DE ÁGUAS (Brasil) (3). Conjuntura dos recursos hídricos no Brasil: regiões hidrográficas brasileiras - Edição Especial. 2015b. 164 p. Brasília.

AGÊNCIA NACIONAL DE ÁGUAS (Brasil) (4). Atlas Brasil: Abastecimento Urbano de Água. Disponível em: <http://atlas.ana.gov.br/Atlas/forms/Home.aspx>. Acesso em: 09 de abril de 2015. 2015c.

ALKMIM, F.F. O que faz de um cráton um cráton? O cráton do São Francisco e as revelações almeidianas ao delimitá-lo. In: MANTESSO-NETO, V.; BARTORELLI, A.; CARNEIRO, C.D.R.; BRITO-NEVES, B.B. Geologia do continente sul-americano: Evolução da obra de Fernando Flávio Marques de Almeida. Beca, 2004, pag. 17-35.

ALLÈGRE, C.J. Isotope Geology. Cambridge: Cambridge University Press, 2008. 534p.

ANDRADE, J.B.M. \& LEAL, L.R.B. Fatores influentes no potencial e processos de salinização dos aquíferos fraturados cristalinos do alto da Bacia do Rio Vaza-Barris, região de Uauá, Bahia, Brasil. 2010. 171 p. Dissertação de mestrado - Instituto de Geociências Universidade Federal da Bahia. Salvador. 2010.

ARAGUAS, L. International Seminar: Application of Isotopes in Hydrology. Rio de Janeiro: CPRM-IAEA, 2014.

ASANO, T. Artificial recharge of groundwater. USA. 1985.

BANTON, D. \& KLISCH, M. Aquifer storage and recovery in a compartmentalized basalt aquifer system, Walla Walla, Washington. Management of Aquifer Recharge for Sustainability, Phoenix - Arizona - EUA, pag. 307-320, 2007.

BARBOSA C.M.S. \& MATTOS A. Conceitos e diretrizes para recarga artificial de aquíferos. In: XV CONGRESSO BRASILEIRO DE ÁGUAS SUBTERRÂNEAS, 2008. Natal - RN.

BELTRÃO, B.A.; MASCARENHAS, J.C.; MIRANDA, J.L.F.; JUNIOR, L.C.S.; GALVÃO, M.J.T.G.; PEREIRA, S.N. Projeto Cadastramento de Fontes de Abastecimento por Água Subterrânea Estado de Pernambuco: Diagnóstico do Município de Petrolina. Recife: CPRM, 12 p. 2005.

BHATTACHARYA, A.K. Artificial ground water recharge with a special reference to India. IJRRAS, v. 4, n 2, 2010.

BOTELHO, C.L. Seca: Visão Dinâmica, Integrada e Correlações. Fortaleza: ABC Fortaleza, 2000. 300 p.

BOUWER, H. Artificial recharge of groundwater: hydrogeology and engineering. Hydrogeology Journal, v. 10, pag. 121-142, 2002.

BRASIL. Ministério do Meio Ambiente. Resolução CONAMA n 396, de 3 de abril de 2008. Dispõe sobre a classificação e diretrizes ambientais para o enquadramento das águas subterrâneas e dá outras providências. Diário Oficial da União, Brasília, DF, 07 de abril de 2008. Seção 1, pag. 64-68. Disponível em: 
<www.mma.gov.br/port/conama/legiabre.cfm?codlegi=562>. Acesso em: 30 de agosto de 2016.

BROWN, R.F. \& KEYS, W.S. Effects of artificial recharge on the Ogallala aquifer, Texas. U.S. Geological Survey water-supply paper 2251, Washington-USA, 56 p., 1985.

CADAMURO, A.L.M. \& CAMPOS, J.E.G. Recarga Artificial de Aquíferos Fraturados no Distrito Federal: Uma Ferramenta para a Gestão dos Recursos Hídricos. Revista Brasileira de Geociências, v. 35, pag. 89-98, 2005.

COSTA, A.M.B.; MELO, J.G.; SILVA, F.M. Aspectos da salinização das águas do aquífero cristalino no Estado do Rio Grande do Norte, nordeste do Brasil. Águas Subterrâneas, v. 20, $\mathrm{n}^{\circ} 01$, pag. 67-82, 2006.

CUSTODIO, E. \& VILARÓ, F. Recarga Artificial de Acuíferos Subterráneos. In: CUSTODIO, E.; LLAMAS, M.R. Hidrologia Subterranea. Barcelona: Omega, 1983, pag. 1963-2026.

EATON, L \& WINSHIP, D. The city of Beavertons basalt-hosted ASR project: A successful case study. Management of Aquifer Recharge for Sustainability, Phoenix - Arizona - EUA, pag. 494-506, 2007.

EMPRESA BRASILEIRA DE PESQUISA AGROPECUÁRIA (Brasil). Documento 168: Informações Agrometeorológicas do Polo Petrolina-PE/Juazeiro-BA. 2001. Petrolina - PE.

FEITOSA, F.A.C.; FILHO, J.M.; FEITOSA, E.C.; DEMETRIO, J.G.A. Hidrogeologia: Conceitos e Aplicações. $3^{\circ}$ ed. Rio de Janeiro: CPRM, 2008. 812 p.

FERRACINI, V.L.; PESSOA, M.C.Y.P.; SILVA, A.S.; SPADOTTO, C.A. Análise de risco de contaminação das águas subterrâneas e superficiais da região de Petrolina (PE) e Juazeiro (BA). Pesticidas: R. Ecotoxicol. e Meio Ambiente, Curitiba - PR, v. 11, pag. 1-16, 2001.

FETTER, C.W. Applied Hydrogeology. $4^{\circ}$ ed. EUA: Prentice Hall, 2001. 615 p.

FRAPE, S.K.; FRITZ, P.; MCNUTT, R.H. Water-rock interaction and chemistry of groundwaters from the Canadian Shield. Geochimica et Cosmochimica Acta, v. 48, pag. 1617-1627, 1984.

FREEZE, R.A. \& CHERRY, J.A. Groundwater Resource Evaluation. In: FREEZE, R.A. \& CHERRY, J.A. Groundwater. EUA: Prentice Hall, 1979, pag. 303-375.

GASCOYNE, M. \& KAMINENI D.C. The Hydrogeochemistry of fractured plutonic rocks in the Canadian Shield. Applied Hydrogeology, v. 02, pag. 43-49, 1994.

GAT, J.R.; MOOK, W.G.; MEIJER, H.A.J. Volume 02: Atmosferic water. In: EUA, UNESCO. Environmental isotopes in the hydrological cycle: Principles and Applications. EUA: IAEA e UNESCO, 2001.

GEYH, M. Volume 04: Groundwater: Saturated and unsaturated zone. In: EUA, UNESCO. Environmental isotopes in the hydrological cycle: Principles and Applications. EUA: IAEA e UNESCO, 2001. 310 p.

GOLDSHMID, J. Water-quality aspects of ground-water recharge in Israel. American Water Works Association, v. 66, n 3, pag. 163-166, 1974.

GREENME. Pernambuco inaugura dessalinizador de água movido a energia solar. Disponível em: $\quad<$ http://www.greenme.com.br/informar-se/cidades/1844-pernambuco-inauguradessalinizador-solar-de-agua>. Acesso em: 18 de maio de 2015.

GROVEA, D.B. \& WOOD, W.W. Prediction and field verification of subsurface-water quality changes during artificial recharge, Lubbock, Texas. Groundwater, v. 17, pag. 250-257, 1979 . 
GRÜTZMACHER, G. \& KUMAR, P.J.S. Introduction to Managed Aquifer Recharge (MAR) Overview of schemes and settings worldwide. Research Gate. Conference Paper. 2012.

HARPAZ, Y. \& BEAR, J. Investigations on mixing of waters in underground storage operations. In: XIII ASSEMBLY OF THE IUGG, 1964. Berkeley - Califórnia. IAHS-Red Books, v. 64, pag. 132-153, 1964.

HASUI, Y. Sistema Orogênico Borborema. In: HASUI,Y.; CARNEIRO, C.D.R.; ALMEIDA, F.F.M.; BARTORELLI, A. Geologia do Brasil. Beca, 2012, pag. 252-287.

HEILWEIL, V.M.; SUSONG, D.D.; CRAM, J.C. Reservoir infiltration to fractured sandstone at Sand Hollow, southwestern Utah, U.S.A. Management of Aquifer Recharge for Sustainability, Phoenix - Arizona - EUA, pag. 475-483, 2007.

HOFMANN, T \& TRÖGER, U. Hydrogeological basic survey in the region of Água Fria, Bahia, Brazil. Zbl. Geol. Paläont. Teil 1, v. 3-6, pag. 823-834, 1998.

HOLLÄNDER, H.M.; MULL, R.; PANDA, S.N. A conceptual for managed aquifer recharge using ASR-well for sustainable use of groundwater resources in an alluvial coastal aquifer in eastern India. In: 6TH INTERNATIONAL SYMPOSIUM ON MANAGED ARTIFICIAL RECHARGE OF GROUNDWATER (ISMAR6), 2007. Phoenix - Arizona - EUA. Pag. 15 29.

INSTITUTO BRASILEIRO DE GEOGRAFIA E ESTATÍSTICA (Brasil) (1). Censo Agropecuário 2006: Segunda Apuração. Brasil, Grandes Regiões e Unidades da Federação. 2012, 774 p. Rio de Janeiro.

INSTITUTO BRASILEIRO DE GEOGRAFIA E ESTATÍSTICA (Brasil) (2). Produção Agrícola Municipal: Culturas temporárias e permanentes. v. 41, 2014, 95 p. Rio de Janeiro.

INSTITUTO BRASILEIRO DE GEOGRAFIA E ESTATÍSTICA (Brasil) (3). Produto Interno Bruto dos Municípios 2010-2013: Contas Nacionais Número 49. 2015, 68 p. Rio de Janeiro.

INSTITUTO BRASILEIRO DE GEOGRAFIA E ESTATÍSTICA (Brasil) (4). Cidades@. Disponível em: <http://www.cidades.ibge.gov.br/xtras/perfil.php?lang=\&codmun=261110> . Acesso em: 23 de abril de 2016.

INSTITUTO BRASILEIRO DO MEIO AMBIENTE E DOS RECURSOS NATURAIS RENOVÁVEIS (Brasil). Conjunto de normas legais: Recursos Hídricos. $8^{\circ}$ ed., 2014, 684 p. Brasília.

INSTITUTO NACIONAL DE METEOROLOGIA (Brasil). Disponível em: <http://www.inmet.gov.br/portal/>. Acesso em: 24 de abril de 2016.

INTERNATIONAL ATOMIC ENERGY AGENCY (Austria). Using isotopes for design and monitoring of artificial recharge systems. 2013, 74 p. Viena - Áustria.

JARDIM DE SÁ, E.F.; MACEDO, M.H.F.; FUCK, R.A.; KAWASHITA, K. Terrenos proterozóicos na província Borborema e a margem norte do Cráton do São Francisco. Revista Brasileira Geociências, v. 22, nº 04, pag. 472-480, 1992.

JARDIM DE SÁ, E.F.; MACEDO, M.H.F.; KAWASHITA, K.; PEUCAT, J.J.; LETERRIER, J.; FUCK, R.A. A suíte Serra da Esperança: intrusões alcalinas sintectônicas aos nappes brasilianos na Faixa Riacho do Pontal, NE do Brasil. 39 Congresso Brasileiro de Geologia, SBG, Salvador, v. 6, pag. 499-501, 1996.

LIMA, O.A.L. Estruturas geoelétrica e hidroquímica do sistema aquífero cristalino da Bacia do Alto Rio Curaçá, semiárido da Bahia. Revista Brasileira de Geofísica, v. 28, nº 03, pag. 445461, 2010. 
MARTIN, R. \& DILLION, P. Aquifer Storage and Recovery: Future directions for South Australia. Department of water, land and biodiversity conservation - DWLBC. 2002.

MARTINELLI, L.A.; OMETTO, J.P.H.B.; FERRAZ, E.S.; VICTORIA, R.L.; CAMARGO, P.B.; MOREIRA, M.Z. Desvendando questões ambientais com isótopos estáveis. São Paulo: Oficina de Textos, 2009. $144 \mathrm{p}$.

MINISTÉRIO DO MEIO AMBIENTE (Brasil). Caatinga. Disponível em: <http://www.mma.gov.br/biomas/caatinga>. Acesso em: 04 de maio de 2016.

MONTGOMERY, J.; EVANS, J.A.; WILDMAN, G. 87Sr/86Sr isotope composition of bottled British mineral waters for environmental and forensic purposes. Applied Geochemistry, v. 21, pag. 1626-1634, 2006.

MOOK, W.G. Volume 1: Introduction: Theory, methods, review. In: IAEA, UNESCO. Environmental isotopes in the hydrological cycle: Principles and Applications. EUA: IAEA e UNESCO, 2001, 185 p.

MOURA-JÚNIOR, E.G. ; ABREU, M.C. ; SEVERI, W. ; LIRA, G.A.S.T. O gradiente riobarragem do reservatório de Sobradinho afeta a composição florística, riqueza e formas biológicas das macrófitas aquáticas? Rodriguésia, v. 62(4), pag. 731-742, 2011.

NELSON, D. \& MELADY, J. Denitrification in a deep basalt aquifer: Implications for aquifer storage and recovery. Groundwater, v. 52, $\mathrm{n}^{\circ}$ 3, pag. 414-423, 2014.

NETO, M.B.O; CUNHA, T.J.F.; NASCIMENTO, A.F.; AMARAL, A.J.; ALVES, E.S.; MARQUES, F.A. Relação solo-geologia da área de estudo do projeto Fragissolos em Petrolina-PE. I Reunião Nordestina de Ciência do Solo, Paraíba, 2013.

OKUBO, T \& MATSUMOTO, J. Effect of infiltration rate on biological clogging and water quality changes during artificial recharge. Water Resources Research, v. 15, pag. 1536$1542,1979$.

OLIVA, A. \& KIANG, C.H. Caracterização hidroquímica de águas subterrâneas no município de Rio Claro - SP. Livro de resumos do XII Congresso Brasileiro de Águas Subterrâneas, São Paulo, 27 p., 2002.

PÁDUA, A.I. ; BORGES, W.R. ; CUNHA, L.S. ; LAGO, A.L. ; CAMPOS, J.E.G. Integração de dados geofísicos para a identificação de zonas de fratura. In: $13^{\circ}$ INTERNATIONAL CONGRESS OF THE BRAZILIAN GEOPHYSICAL SOCIETY, 2013. Rio de Janeiro.

PICOT-COLBEAUX, G.; THIÉRY, D.; SARAH, S.; BOISSON, A.; PETTENATI, M.; PERRIN, J.; DEWANDEL, B.; MARÉCHAL, J.C.; AHMED, S.; KLOPPMANN, W. Modeling artificial recharge capacity of fractured hard rock under semi-arid conditions in Southern India: Implementing storage basin dynamics into MARTHE code. In: $8^{\circ}$ INTERNATIONAL SYMPOSIUM ON MANAGED AQUIFER RECHARGE: MEETING THE WATER RESOURCE CHALLENGE, 2013. China.

POEHLS, D.J. \& SMITH, G.J. Encyclopedic dictionary of hydrogeology. $1^{\circ}$ ed. EUA: ELSEVIER, 2009. 517p.

SANTIAGO, M.F.; FRISCHKORN, H.; SILVA, C.M.S.V. Métodos isotópicos. In: FEITOSA, F.A.C.; FILHO, J.M.; FEITOSA, E.C.; DEMETRIO, J.G.A. Hidrogeologia: Conceitos $e$ Aplicações. Rio de Janeiro: CPRM, 2008, pag. 255-270.

SANTIAGO, M.M.F.; FRISCHKORN, H; FILHO, J.M. Mecanismos de salinização em água do Ceará, Rio Grande do Norte e Piauí. Anais do 1st Joint World Congress on Groundwater, Fortaleza, 2000.

SERVIÇO GEOLÓGICO DO BRASIL (CPRM) (Brasil) (1). Ação da CPRM contribui para a 
solução de falta d'água em municípios do semiárido. 2014a. Disponível em: <http://cprmblog.blogspot.com.br/2014/10/acao-da-cprm-contribui-para-solucao-de.html>. Acesso em: 15 de outubro de 2014.

SERVIÇO GEOLÓGICO DO BRASIL (CPRM) (Brasil) (2). Programa Geologia do Brasil: Folha Petrolina (SC.24-V-C-III) Escala 1:100.000. 2014b. Disponível em: < http://geobank.cprm.gov.br/>. Acesso em: 10 de julho de 2016.

SERVIÇO GEOLÓGICO DO BRASIL (CPRM) (Brasil) (3). Programa Água Doce investe R\$ 61 milhões na Bahia. 2015. Disponível em: <http://www.brasil.gov.br/meioambiente/2015/03/programa-agua-doce-investe-r-61-milhoes-na-bahia>. Acesso em: 31 de março de 2015.

SERVIÇO GEOLÓGICO DO BRASIL (CPRM) (Brasil) (4). Atlas hidrogeológico do Brasil ao milionésimo. 2016. Disponível em: <www.cprm.gov.br/publique/Hidrologia/Mapas-ePublicacoes/Atlas-Hidrogeologico-do-Brasil-ao-Milionesimo-4267.html>. Acesso em: $01 \mathrm{de}$ novembro de 2016.

SILVA JUNIOR, L.G.A.; GHEYI, H.R.; MEDEIROS, J.F. Composição química de águas do cristalino do nordeste brasileiro. Revista Brasileira de Engenharia Agrícola e Ambiental, Campina Grande - PB, v. 3, nº 1, pag. 11-17, 1999.

SILVA, C.M.L. \& OLIVEIRA, N.M.G.A. Estudo das dinâmicas territoriais do município de Petrolina-PE: Uma alternativa para o desenvolvimento sustentável. Dissertação de Mestrado - Faculdade de Ciências da Administração de Pernambuco - Universidade Federal de Pernambuco. Recife. 2012.

SILVA, L.F. Modelo conceitual do aquífero fraturado da área da jazida de urânio de Caetité, Bahia: Implicações para o fluxo subterrâneo. Dissertação de Mestrado - Instituto de Geociências - Universidade de Brasília. Brasília. 2015.

SILVA, M.J.R. \& FERREIRA, S.R.M. Comportamento geomecânico de solos colapsíveis e expansivos em Petrolina-PE: Cartas de suscetibilidade. Dissertação de Mestrado - Centro de Tecnologia e Geociências - Universidade Federal de Pernambuco. Recife. 2003.

SILVA, R.B.G. \& REBOUÇAS, A.C. Estudo hidroquímico e isotópico das águas subterrâneas do Aquífero Botucatu no estado de São Paulo. 166 p. Tese de Doutorado - Instituto de Geociência - Universidade de São Paulo. São Paulo. 1983.

SILVEIRA, C.S. \& SILVA JUNIOR, G.C. O uso de isótopos ambientais em estudos hidrogeológicos no Brasil: Uma resenha crítica. Anuário do Instituto de Geociência UFRJ, Rio de Janeiro, v. 25, pag 25-43, 2002.

STAMOS, C.L.; MARTIN, P.; EVERETT, R.R.; IZBICKI, J.A. The effects of artificial recharge on groundwater levels and water quality in the West Hydrogeologic Unit of the Warren Subbasin, San Bernardino County, California. Scientific Investigations Report 2013-5088, Reston - Virginia, 47 p., 2013.

STORANI, D.L. \& PEREZ FILHO, A. Relações morfo-litológicas na organização do relevo brasileiro. 2008. 14 p.

UHLEIN, A.; ALVARENGA, C.J.S.; TROMPETTE, R.; DUPONT, H.S.J.B.; SILVA, M.E.; CUKROV, N.; LIMA O.N.B. Glaciação neoproterozóica sobre o cráton do São Francisco e faixas dobradas adjacentes. In: MANTESSO-NETO, V.; BARTORELLI, A.; CARNEIRO, C.D.R.; BRITO-NEVES, B.B. Geologia do continente sul-americano: Evolução da obra de Fernando Flávio Marques de Almeida. Beca, 2004, pag. 539-553.

UHLEIN, A.; CAXITO, F.A.; SANGLARD, J.C.D.; UHLEIN, G.J.; SUCKAU, G.L. Estratigrafia e tectônica das faixas neoproterozoicas da porção norte do Cráton do São 
Francisco. Geonomos, v. 19 (2), pag. 8-31, 2011.

VAN SCHMUS, W.R.; BRITO NEVES, B.B.; HACKPACHER, P.; BABINSKI, M. U-Pb and Sm-Nd geochronological studies of the Eastern Borborema province, Northeast Brazil: initial conclusions. Journal of South American Earth Sciences, v. 08, pag. 267-288, 1995.

WILLIAM, J.W. \& HAUGH, C.J. Preliminary conceptual models of chlorinated-solvent accumulation in karst aquifers. U.S. Geological Survey, Nashville - EUA, v. 01-4011, pag. 157-162, 2001.

WOLF,L.; WERZ, H.; HOETZL, H.; GHANEM, M. Exploring the potential of managed aquifer recharge to mitigate water scarcity in the lower Jordan river basin within an IWRM approach. Management of Aquifer Recharge for Sustainability, Phoenix - Arizona - EUA, pag. 30-46, 2007. 